\title{
IMPACT OF A CARE PATHWAY FOR EXACERBATION OF CHRONIC OBSTRUCTIVE PULMONARY DISEASE (COPD): A CLUSTER RANDOMISED CONTROLLED TRIAL
}

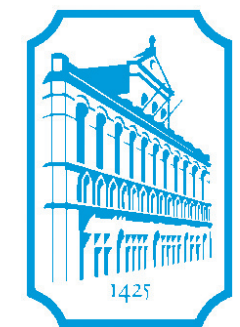


ACTA BIOMEDICA LOVANIENSIA 582

Katholieke Universiteit Leuven

Faculty of Medicine

Group Biomedical Sciences

School of Public Health

Center for Health Services and Nursing Research

\section{IMPACT OF A CARE PATHWAY FOR \\ EXACERBATION OF CHRONIC OBSTRUCTIVE PULMONARY DISEASE (COPD): A CLUSTER RANDOMISED CONTROLLED TRIAL}

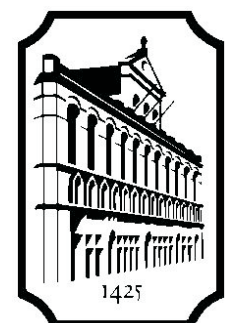

LEUVEN UNIVERSITY PRESS 
ACTA BIOMEDICA LOVANIENSIA 582

Katholieke Universiteit Leuven

Faculty of Medicine

Group Biomedical Sciences

School of Public Health

Center for Health Services and Nursing Research

\section{IMPACT OF A CARE PATHWAY FOR \\ EXACERBATION OF CHRONIC OBSTRUCTIVE PULMONARY DISEASE (COPD): A CLUSTER RANDOMISED CONTROLLED TRIAL}

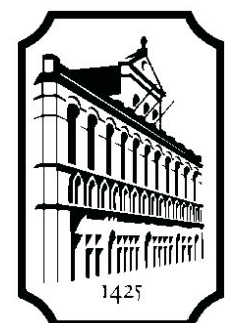

LEUVEN UNIVERSITY PRESS 
"Quality is never an accident; it is always the result of intelligent effort." (John Ruskin) 


\section{Dankwoord}

Dit doctoraatonderzoek is het resultaat van teamwerk, en zou niet mogelijk geweest zijn zonder de steun van collega's, familie en vrienden. Een aantal mensen wil ik dan ook speciaal bedanken.

In de eerste plaats wil ik mijn promotor Prof. Marc Decramer danken. Prof. Decramer, u was van in het begin een stuwende kracht om dit doctoraat te doen slagen. $U$ hebt er mede voor gezorgd dat ik mijn doctoraatonderzoek kon aanvatten, en onder optimale omstandigheden kon beëindigen. Uw klinische en wetenschappelijke input waren onontbeerlijk voor dit doctoraatonderzoek. Ook apprecieer ik erg de vlotte en efficiënte samenwerking.

Vervolgens wil ik mijn co-promotoren danken, Prof. Walter Sermeus en Dr. Kris Vanhaecht. Walter en Kris, ik wil u beiden danken dat $u$ mij de kans gaf om mee te werken aan de EQCP study. Ik apprecieer het ook erg dat u beiden mij de mogelijkheid liet om mijn eigen "toets" aan het onderzoek geven, zodat het ook echt mijn doctoraatproject werd. Walter, uw input en kritische feedback zijn essentieel geweest voor de kwaliteit van dit doctoraatonderzoek. Telkens opnieuw slaagde u erin om complexe zaken op een ludieke en begrijpbare manier te duiden en in zijn gehele context te plaatsten. Dit heeft mij enorm geholpen om de logica en samenhang doorheen dit doctoraatproject te behouden, alsook heeft het mij steeds opnieuw getriggerd om "die stap verder te denken" en het onderzoek weer vanuit een andere context te gaan bekijken. Kris, jou wil ik danken voor de nabije begeleiding doorheen het ganse doctoraatproject, je was echt een belangrijke determinant in het "succesmodel". Ondanks je drukke agenda maakte je altijd tijd voor overleg, en op een voorstel of draft gaf je als het ware "per kerende" gedetailleerde feedback. Ook onze talrijke brainstormsessies hebben me steeds erg gestimuleerd om zaken te "herdenken" en vanuit nieuwe perspectieven te gaan benaderen, wat zonder twijfel erg heeft bijgedragen tot de kwaliteit van deze doctoraatthesis.

A special word of thanks goes to the other members of the EQCP Research Group: Prof. Massimiliano Panella, Svin Deneckere, Dr. Fabrizio Leigheb, Ilke Montag, Deborah Seys, and to my other colleagues of the Health Services Research Group: Eva Van Gerven, Kristien Kremie, Shahenaz Najjar. Thank you for the excellent and pleasant collaboration, and your advice and support during this doctoral track. I am looking forward to our future collaboration.

I am very grateful for the advices of the jury members of the examining committee, which have led to the final version of this manuscript: Prof. Peter Donceel, Prof. Wim. Janssens, Prof. Arthur Vleugels, Prof. Wisia Wedzicha, and Prof. Hub Wollersheim. 
Ik wil mijn grote dank betuigen aan het Klinisch Onderszoeksfonds van UZ Leuven voor de financiele steun. Eveneens grote dank gaat naar Prof. Em. Jan Peers, die via Peter Menu and Kris Westelinck van Pfizer het volledige EQCP onderzoek mogelijk maakte. Zonder deze externe financiering, contracting en netwerking zou van de European Quality of Care Pathways Study, waarvan dit doctoraat deel uitmaakt, geen sprake geweest zijn.

Heel veel dank gaat naar al de patiënten die bereid waren om deel te nemen aan dit onderzoek. Jullie medewerking betekent een belangrijke bijdrage voor de kwaliteit van de zorgverlening voor COPD patiënten. Vervolgens dank ik alle studiecoördinatoren en teams van de betrokken ziekenhuizen voor hun deelname aan het onderzoek. Jullie enthousiaste en excellente medewerking hebben in sterke mate bijgedragen tot dit resultaat.

Het management van UZ Leuven, met in bijzonder Prof. Johan Kips en Koen Balcaen, wil ik danken omdat ik de kans gekregen heb om als UZ Leuven medewerker dit doctoraattraject te doorlopen. Karine Philippaerts dank ik voor de aanmoediging en de voortreffelijke coaching tijdens het doctoraatproject alsook in mijn functie als verpleegkundig specialist (VS) doorheen de jaren. Christel Stuyven dank ik voor de weliswaar korte maar constructieve samenwerking. Erg veel dank gaat uit naar het verpleegteam van E651, allereerst voor jullie supportering tijdens de master- en doctoraatperiode, maar ook voor de erg fijne en toffe teamwerking. Gert, als hoofdverpleegkundige heb je me steeds enorm ondersteund en aangemoedigd tijdens de doc-periode, ook in "turbulentere" momenten. Verder ook dank aan de artsen en het paramedisch team voor de vele aanmoedigingen. Speciale dank gaat uit naar de hoofdverpleegkundigen van pneumo, Annemie Schoonis, Gert Vanwezer, Mieke Peys, Geert Celis, en naar de collega's van de Belgische Vereniging voor PneumologieVerpleegkundigen (BVPV). Onze uitstekende samenwerking en jullie niet aflatende enthousiasme, alsook onze vriendschap hebben me steeds erg geïnspireerd en gemotiveerd, in mijn rol als VS alsook in het voeren van mijn doctoraatonderzoek. Collega's van bordeaux, inclusief verpleegkundig specialisten, nurse support team en projectmedewerkers, thanks voor de aanmoedigingen, de boeiende brainstorms, alsook de luchtige en ontspannende "bureau"-momenten.

Een aantal mensen wil ik speciaal bedanken. Lon Holtzer, jij gaf de allereerste aanzet om het doctoraat te starten via de indiening van het KOF mandaat. Nadien heb je me ook altijd erg aangemoedigd doorheen het ganse doctoraatproject. Dus merci Lon voor je enthousiasme en je geloof in mijn kunnen en dat van de verpleegkundig specialisten in het algemeen. Joke Lemiengre, ik dank jou voor de geweldige aanmoediging doorheen het ganse doctoraattraject, de geanimeerde gesprekken en de ontspannende etentjes uit, voor de support in de moeilijke levensmomenten, en zeker ook voor het vermogen tot relativeren. Annemarie Coolbrandt, je bent een toffe VS- en doc-collega met de juiste spirit. Ik kan me geen betere bureau-genoot voorstellen, zowel voor je kritische input en onspannende 
gesprekken, alsook om stoom af te laten tijdens de stressy momenten. Marc Verschueren, het clinical leadership project zorgde voor een ommekeer in mijn werk en persoonlijk leven, en was de start van een mooie vriendschap. Dank voor de ventilerende en boeiende gesprekken tijdens de voorbije doc-periode.

De collega's van het CZV dank ik voor het "mede-doctoreren". Jullie input en adviezen, alsook de ontspannende intermezzo's brachten inspiratie en plezier in het doctoraattraject, en hebben me ook geholpen om vol te houden. Mieke en Nathalie, jullie nooit afgaande energie, enthousiasme en humor werkte ook altijd erg aanstekelijk en inspirerend. Bijzondere herinnering heb ik aan het EANS Leuven team en de organisatie van de EANS Summerschool 2012: Walter, Alexandra, Heidi, Elke, Ellen, Deborah, Kristel, Lieve, Luk, Mieke, Philip, Susan. Het was een bijwijlen uitputtende maar vooral bijzondere en toffe teamervaring om een dergelijk event samen tot een geslaagd einde te brengen.

De secretaressen van het CZV, Alexandra, Caroline, Heidi, Mia en Sarah, merci voor al de organisatorische en administratieve ondersteuning, onvoorstelbaar hoe efficiënt jullie het steeds voor elkaar krijgen.

Bijzondere en innige dank gaan uit naar mijn ouders. Moe en va, zo spijtig dat jullie zo snel moesten weggaan. Ik mis jullie elke dag. Ik had vandaag en zoveel andere dingen samen met jullie willen meemaken. Jullie zijn in mijn gedachten, en ik hoop dat jullie het ergens toch allemaal kunnen meebeleven.

Nicky, Marianne en Johanna, Jeske en Nonkel Rieke, Karel, Christa en Ivan, zonder jullie was het zeker niet gelukt om deze doc-periode door te komen. Ik ben blij dat we zoveel steun hebben aan elkaar, zeker om de gebeurtenissen van de voorbij jaren te boven te komen. Bedankt ook voor de supportering, en de superleuke dagjes en avonden uit. Jeske en Nonkel Rieke ook speciaal merci voor alle ondersteuning van de voorbije jaren.

Heel veel dank gaat uit naar al mijn vrienden. Jullie kameraadschap, de ontspannende (Revue-)avonden, de etentjes en de weekends waren de perfecte combinatie om deze doctoraatrace vol te houden.

Pieter, je bent het beste wat me kon overkomen. Ik hou van je humor, je relativerende kijk op het leven, de geanimeerde discussies, en hoe we samen relaxen en genieten van het leven. Zonder jouw gezelschap en liefde was ik de verdrietige gebeurtenissen niet te boven gekomen, alsook had ik jou nodig om dit alles vol te houden. Ook de boeiende gesprekken en fijne etentjes met je mama en zus koester ik enorm. Het samen-zijn en samen dingen doen met jou is alles voor me.

Cathy 


\section{Table of contents}

$\begin{array}{lll}\text { Chapter 1: } & \text { General introduction } & 13\end{array}$

Chapter 2: In-hospital management of COPD exacerbations: a systematic

review of the literature with regard to adherence to international guidelines

Chapter 3: Impact of care pathways for in-hospital management of COPD exacerbation: a systematic review

Chapter 4: Quality indicators for in-hospital management of COPD exacerbation: results of an international Delphi study

Chapter 5: How to build the clinical content of an evidence-based care pathway for COPD exacerbation

Chapter 6: Impact of a care pathway for COPD exacerbation: rationale and design of a cluster randomised controlled trial

Chapter 7: Impact of a care pathway for COPD exacerbation: Preliminary results of the European Quality of Care Pathways (EQCP) Study

Chapter 8: Process analyses in seven Belgian Hospitals: level of implementation of a set of evidence-based key interventions for in-hospital management of COPD exacerbation

Chapter 9: General discussion and recommendations

Summary

Samenvatting

Curriculum Vitae

List of publications 
Chapter 1:

General introduction 


\section{Chronic obstructive pulmonary disease (COPD)}

\section{Definition and burden}

COPD is a preventable and treatable disease. COPD is associated with certain significant extrapulmonary problems, which may contribute to disease severity in individual patients. Its pulmonary component is characterised by airflow limitation that is not fully reversible. The airflow limitation is usually progressive and associated with an abnormal inflammatory response of the lung to noxious particles or gases [1-4]. The most common symptoms of COPD are breathlessness on exertion and cough, either with or without sputum production [2;3]. Worldwide, smoking is the most commonly encountered risk factor for COPD. Air pollution resulting from the burning of wood and other biomass fuels, hereditary a1antitrypsin (a1-AT) deficiency, and certain occupational exposures are also established risk factors for COPD [3;5].

Worldwide, COPD affects $9.8 \%$ of men and $5.6 \%$ of women 40 years and older [6]. Its prevalence is projected to increase in the future due to the long-term impact of an increase in smoking behaviour and population aging [7-10]. COPD continues to be a leading cause of morbidity, mortality, and increased healthcare costs worldwide [5;10-13]. The burden to the patient with COPD is high, both in terms of reduced health-related quality of life and health status. In addition, COPD is one of the major causes of death in adult populations $[5 ; 11 ; 12]$. The Global Burden of Disease Studies found that COPD was the sixth most common cause of death worldwide in 1990 [10]. These authors made the alarming prediction that COPD would become the third most common cause of death by 2020, irrespective of public health intervention [10]. Finally, COPD also places a high economic burden on healthcare systems and society [14-17]. In 2010, COPD alone was estimated to have cost the global economy USD $\$ 400$ billion [18].

\section{COPD exacerbations}

COPD patients experience frequent exacerbation of symptoms [19-21]. COPD exacerbations are defined as events in the natural course of the disease-characterised by a change in baseline dyspnoea, cough, and/or sputum — that are beyond normal day-to-day variations, are acute in onset, and may warrant a change in regular management [1;3;22]. The annual rate of COPD exacerbations ranges from 0.5 to 3.5 exacerbations per patient [19;21].

COPD exacerbations contribute tremendously to the disease burden. They are a leading cause of hospital admissions worldwide, with 35\% of COPD patients having at least one admission a year and up to $40 \%$ of admitted patients having two or more readmissions a year [20;23;24]. These acute hospital admissions account for the majority (43 to $84 \%$ ) of the overall direct costs related to COPD [16;25-27]. Furthermore, COPD exacerbations have a 
serious impact on functional status [19;28] and patients' quality of life [19;21;29], and up to $30 \%$ of patients die within one year after hospitalisation [30;31].

Management of exacerbations should focus on prevention and reduction of COPD exacerbations in order to achieve quality of life after exacerbation, and should focus on reduction of healthcare resource utilisation in terms of hospital admissions and length of stay (LOS) [3;32]. The management of a COPD exacerbation can take place on an outpatient basis at home (level I), in the hospital at the emergency department (ED) or in the respiratory ward (RW) (level II), or in the ICU (level III). Research shows that hospital at-home care represents an effective, safe, and cost-reducing alternative, provided that patients do not suffer acidotic respiratory failure [33-35]. The risk of dying from an exacerbation of COPD is closely related to the development of respiratory acidosis, the presence of significant comorbidities, and the need for ventilator support [3;36]. The presence of these features often require hospitalisation [3;22;37], and attempts to manage such patients entirely in a community setting has had only limited success [38].

Several guidelines describe various criteria and indications for hospitalisation of COPD patients, including the presence of high-risk comorbid conditions like pneumonia, cardiac arrhythmia and congestive heart failure, diabetes mellitus, renal or liver failure, inadequate response of symptoms to outpatient management, marked increase in dyspnoea, inability to manage at home, etc. [3;22;37]. This PhD dissertation focusses on the in-hospital management of COPD exacerbations in the ED and in the respiratory ward (level II).

Since 2000, several evidence-based clinical practice guidelines (CPGs) for the management of COPD have been established worldwide [39]. These include, for example, the guidelines of the Global Initiative for Chronic Obstructive Pulmonary Disease (GOLD) [3]; guidelines of the American Thoracic Society (ATS)-European Respiratory Society Task Force (ERS) [40]; and guidelines of the National Institute for Clinical Excellence [37]. These guidelines have very few areas of clinically relevant variation, are freely available, and provide for regular update [39]. Hence, professionals caring for COPD patients are expected to know these guidelines well, and adherence to these guidelines therefore should be high.

However, according to acknowledged clinical practice guidelines, the care process for patients hospitalised with COPD exacerbations includes a large range of diagnostic, pharmacological, and non-pharmacological interventions, which require a multidisciplinary approach involving physicians, nurses, physiotherapists, social workers, occupational therapists, and dieticians. Furthermore, coordination of the care process among multiple caregivers is complex, an integrated and systematic approach is needed [3;37;40-42]. These considerations led us to pose the following questions: Is the actual care process for patients hospitalised with COPD exacerbations really well organised? Does delivered care fully comply with international guidelines and does this care result in optimal outcomes? 
A very popular strategy for reorganising care processes and optimising clinical outcomes is the implementation of care pathways, which are also known as clinical pathways or critical pathways [43-50].

\section{Care pathways}

\section{Definition}

The care pathway method has been used in industry since the 1950s [48;50]. It was adopted for the first time in healthcare in 1985 at the New England Medical Center (Boston, MA, USA) and was inspired by Karen Zander and Kathleen Bower [48;50]. Today, care pathways are used worldwide in a variety of settings, with the aim of maintaining and improving the quality and efficiency of healthcare process [43-45;48;50-53].

Care pathways are defined as complex interventions for the mutual decision making and organisation of predictable care for a well-defined group of patients during a well-defined period $[43-45 ; 48 ; 50]$. Their aim is to enhance the quality of care across the continuum by improving risk-adjusted patient outcomes, promoting patient safety, increasing patient satisfaction, and optimising the use of resources [43-45;48;50]. Defining characteristics of care pathways include an explicit statement of the goals and key elements of care based on evidence, best practice and patient expectations; the facilitation of communication and coordination of roles, and sequencing the activities of the multidisciplinary care team, patients, and their relatives; the documentation, monitoring, and evaluation of variances and outcomes; and the identification of relevant resources [43-45;48;50;52]. Different methodologies for development and implementation of care pathways exist [54;55]. These are based on the Plan-Do-Study-Act (PDSA) cycle, as described by Edwards Deming $[51 ; 55 ; 56]$.

A care pathway is explicitly defined as a "complex intervention" [43;45;48;51;52;57;58]. Complex interventions in healthcare comprise a number of interacting components that seem essential to the proper functioning of the intervention, although the effective "active component" of the intervention is difficult to specify [59;60]. Active ingredients of a care pathway might be the level of multidisciplinary teamwork, the integration of a package of evidence-based key interventions, and the active follow-up of the care process [47]. When considering a spectrum of low to high complexity, development of a drug would be at the low end of the complexity spectrum, while evaluation of the effectiveness of a stroke unit would be at the high end of the spectrum. The greater the difficulty in defining precisely what the "active component" of an intervention is and how it relates to other components, the greater the likelihood that one is dealing with a complex intervention [59;60]. 


\section{Framework for development and evaluation of complex interventions}

Evaluating the effectiveness of complex interventions like care pathways is complicated due to a number of special problems, besides dealing with the typical problems related to practical and methodological issues that any successful evaluation must overcome. Many of these special problems are related to the difficulty of standardising the design and delivery of the interventions, their sensitivity to features of the local context, the organisational and logistical difficulty of applying experimental methods to service or policy changes, and the length and complexity of the causal chains linking the intervention with outcome [60].

As a consequence, when evaluating complex interventions like care pathways, several essential questions must be answered. (i) Does the intervention work in everyday practice? (ii) How does the intervention work? What are the active ingredients within the intervention? [59] The second question is crucial in order to identify weak links in the causal chain and consequently remove or strengthen these components, and in order to know how the intervention can be generalised and put into operation in other contexts [60]. (iii) What are the characteristics of the context where the complex intervention is being implemented? Understanding the context and the different organisation levels affected by the intervention is essential for optimisation and generalisation of the intervention $[61 ; 62]$.

To deal with this complexity, the Medical Research Council developed in 2000 the framework for developing and evaluating complex interventions [59;63]. Based on the sequential phases of drug development, this framework presents a step-wise approach composed of five phases (Figure 1): (i) Preclinical or theoretical phase, (ii) Phase 1 or modelling, (iii) Phase 2 or exploratory trial, (iv) Phase 3 or definitive randomised controlled trial, and $(v)$ Phase 4 or long-term implementation [59;63]. During the Preclinical or theoretical phase, evidence that the intervention might have the desired effect is identified. Phase 1 or modelling involves identification of components of an intervention and their interrelationships. During the Phase 2 or exploratory trial, the intervention is tested for its acceptability and feasibility, the control intervention is defined, sample size is calculated, and outcome measures are piloted. Phase 3 or definitive randomised controlled trial addresses sample size, inclusion exclusion criteria, and methods of randomisation. Finally, Phase 4 or long-term implementation assesses the stability and real-life effectiveness of the intervention, its broader applicability outside of a research context, and possible existence of adverse effects [59;63]. 


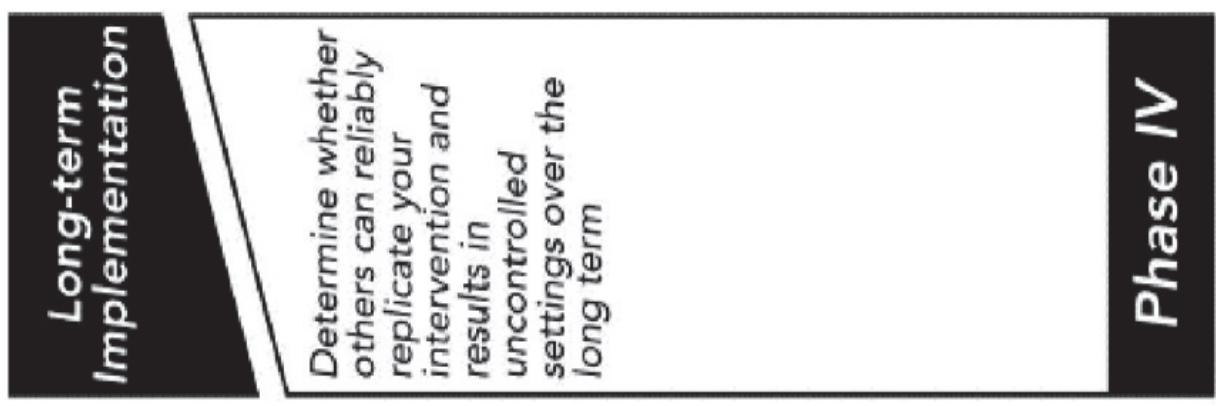

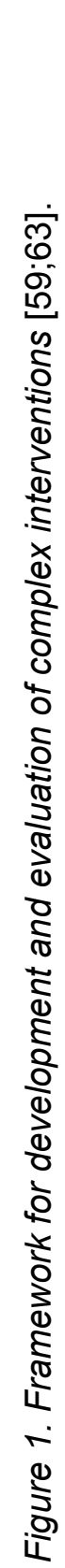
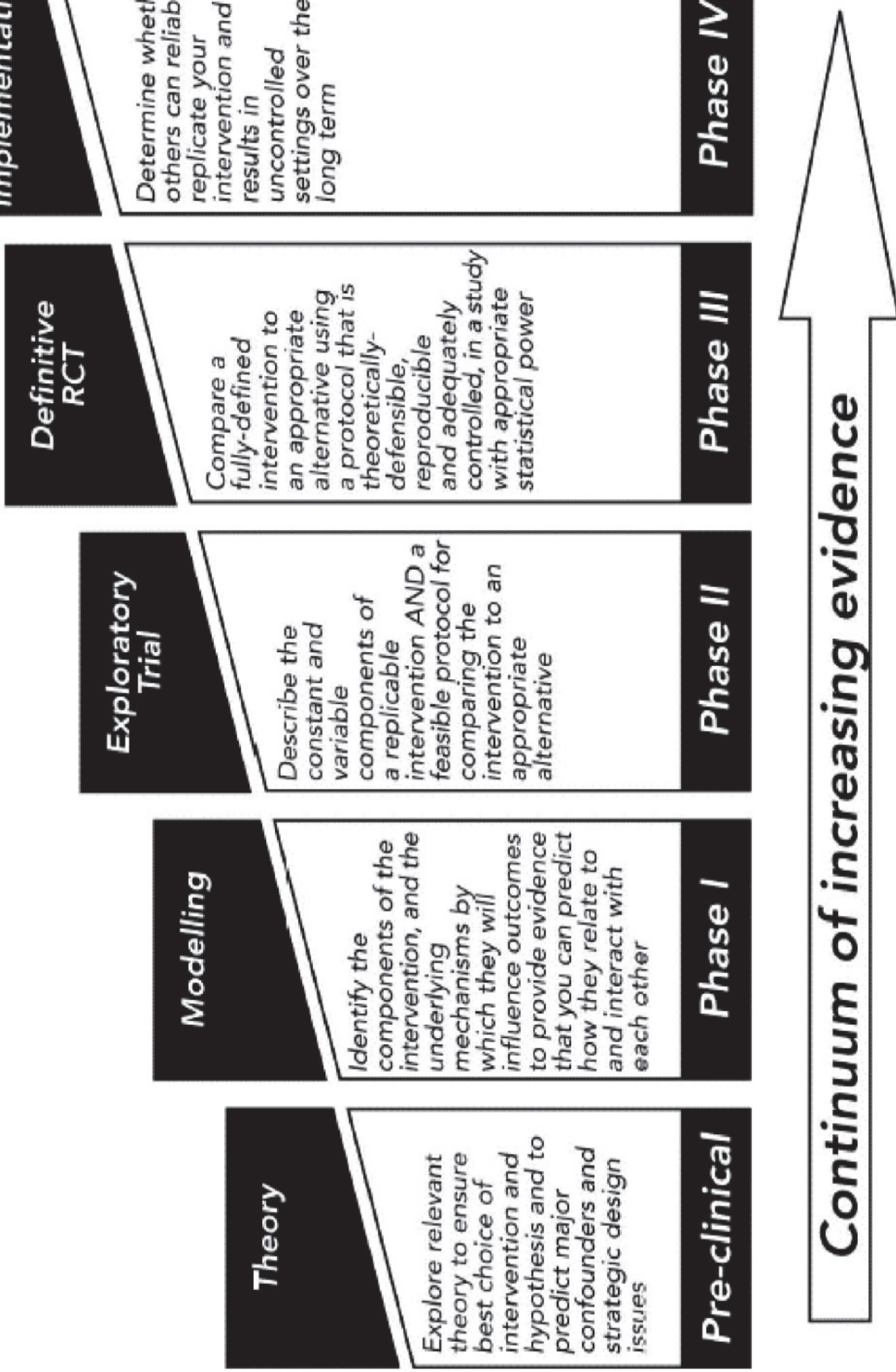
It is useful for investigators to consider the development and evaluation of complex interventions as several distinct phases. Doing so allows them to separate out the different questions being addressed [63], and it will also help them to determine the state of knowledge and uncertainty regarding the complex intervention at given times [59]. However, in practice these phases may not follow a linear or even a cyclical sequence [59;60;62-64]. In many cases an iterative process occurs: For example, if an exploratory trial finds that a complex intervention is unacceptable to potential recipients, then the theoretical basis and components of the intervention may have to be re-examined [63].

As a consequence, in 2008 the 2000 framework was updated and extended into an iterative, less linear model of the process [60]. Figure 2 presents the main stages and the key functions and activities of each stage. The arrows indicate the main interactions between the phases (Figure 2) [60]. Specific key points in the new model include [60] greater attention to early phase piloting and development work [65], integration of process and outcome evaluation [66], recognition that complex interventions may work best if they are tailored to local context rather than completely standardised [67], and greater use of insights provided by the theory of complex adaptive systems [68].

Figure 2. Updated framework for the development and evaluation of complex interventions [60].

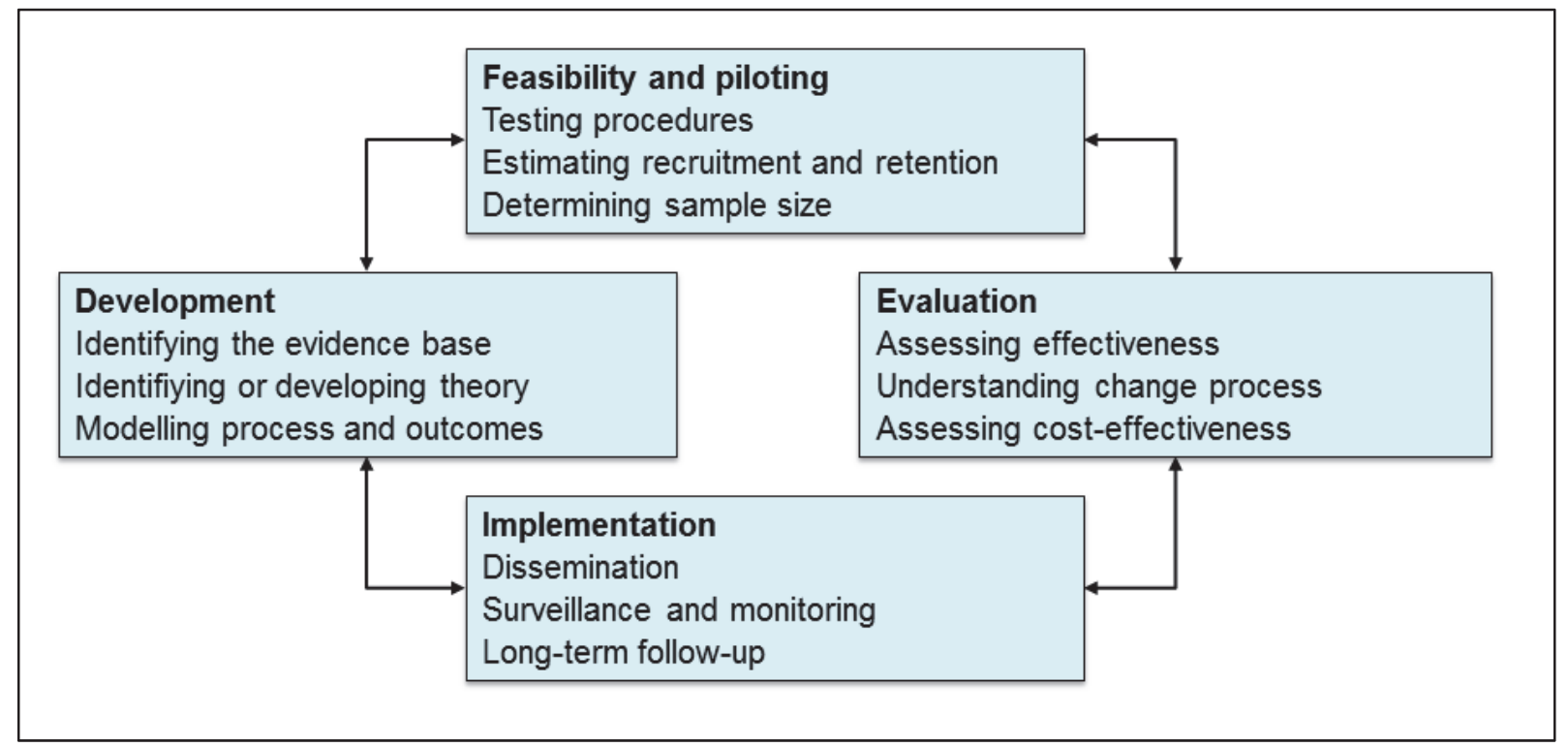

\section{What about existing research on care pathways?}

During recent decades, effectiveness of care pathways has been widely studied, and several positive effects on process and clinical outcomes-and to an lesser extent on team, service, and financial outcomes-have been reported [46;69-71]. However, until now, effectiveness of 
care pathways remaines questionable because methodological quality of available care pathway research is poor with regard to research design and sample size $[46 ; 51 ; 52 ; 69]$.

Firstly, an experimental design is the golden standard of clinical research, although it is not frequently used in the evaluation of care pathways [46;52;69-71]. Care pathways induce change at different levels of the organisation (i.e. patient, team, hospital, etc.). To deal with these multilevel effects, a cluster randomised design (cRCT) should be used when evaluating care pathway effectiveness [60;72-75]. In cRCTs, clusters like organisations or teams, rather than patients, are randomised to an intervention and a control group, but outcomes are measured on the individuals within the clusters [72]. However, it is much more difficult to randomise multidisciplinary teams or organisations into experimental and control groups compared to randomisation of patients, which occurs in conventional RCTs [46]. Consequently, until now, only five cRCTs on pathway effectiveness have been conducted [73;74;76-78]. Furthermore, very often a quasi-experimental design, like a pretest-posttest design, is used to evaluate care pathway effectiveness [46;69-71]. Although this kind of study can produce very useful results, several sources of potential bias are present: (i) contamination of the control group with information on the intervention; (ii) selection bias when evaluating a complex intervention in a single organisation with its specific context (e.g. coordination of the care process, the multidisciplinary team, and specific types of patients), it is difficult or even impossible to ascertain whether the results depend on the context under study or whether they are generalisable to a wider context; (iii) history - outcomes could have been caused by a historical event and were possibly not related to the intervention (i.e. financial incentives to reduce LOS); (iv) the Hawthorne effect or effect of attention due to the project - performance of care processes during the trial could have temporarily improved because of the attention given the project, not because of the implementation of the care pathway itself [62;64;79-83].

Secondly, sample sizes included in existing studies tend to be low [46;69-71], providing for insufficient statistical power and thus inconclusive results.

Thirdly, different interventions are classified under the term 'care pathway'. Moreover, many published studies fail to clearly report the development, implementation, and characteristics of their intervention. As a consequence, insufficient details are available for identification of possible active components of the studied intervention, and for replication and application of the intervention in other settings $[46 ; 52 ; 60 ; 69]$.

Fourthly, most previous studies fail to describe and explain contextual factors [52]. Care pathway mechanisms involve active ingredients like integration of a set of key interventions, information on the organisation and design of the care process, and the development and follow-up of the care pathway. However, fine-tuning of the intervention is based on bottlenecks and on the context of the organisation and multidisciplinary teams involved [52]. 
In other words, an effective pathway in one place may be ineffective in another place, and so contextual factors need to be taken into account when evaluating care pathways [52].

In conclusion, we see the need for large multicentre trials that include information on the mechanisms used, and on the context of the involved organisations [84].

\section{European Quality of Care Pathways (EQCP) study}

To answer previous questions, the European Pathway Association (www.E-P-A.org) launched in 2009 the EQCP study. This is an international CRCT conducted with two main aims: (i) to study the effect of the implementation of care pathways on care processes and clinical outcomes, and (ii) to study why and under what circumstances pathways work [84]. The study is being performed in four countries: Belgium, Italy, Ireland, and Portugal.

The EQCP study includes three individual trials [84]: a trial including patients hospitalised with COPD exacerbations [85], a trial including proximal femur fracture (PFF) patients [86], and a trial focussing on multidisciplinary teamwork within both populations [87]. In both COPD and PFF patient populations and teams, structure, process, and outcome indicators are studied (Table 1) [84].

Table 1. The European Quality of Care Pathway study approach [84]

\begin{tabular}{|c|c|c|c|}
\hline EQCP & STRUCTURE & PROCESS & OUTCOMES \\
\hline COPD exacerbation & $\begin{array}{l}\text { - Team structure } \\
\text { indicators } \\
\text { - COPD organisation } \\
\text { factors }\end{array}$ & $\begin{array}{l}\text { Compliance to COPD } \\
\text { evidence-based key } \\
\text { interventions }\end{array}$ & $\begin{array}{l}\text { Performance on COPD } \\
\text { risk-adjusted outcome } \\
\text { indicators }\end{array}$ \\
\hline $\begin{array}{l}\text { Proximal femur } \\
\text { fracture (PFF) }\end{array}$ & $\begin{array}{l}\text { - Team structure } \\
\text { indicators } \\
\text { - PFF organisation } \\
\text { factors }\end{array}$ & $\begin{array}{l}\text { Compliance to PFF } \\
\text { evidence-based key } \\
\text { interventions }\end{array}$ & $\begin{array}{l}\text { Performance on PFF } \\
\text { risk-adjusted outcome } \\
\text { indicators }\end{array}$ \\
\hline Teamwork & $\begin{array}{ll}\text { - Team structure } \\
\text { indicators }\end{array}$ & $\begin{array}{l}\text { Performance on team } \\
\text { process indicators }\end{array}$ & $\begin{array}{l}\text { Performance on team } \\
\text { outcome indicators }\end{array}$ \\
\hline
\end{tabular}

Three different $\mathrm{PhD}$ dissertations have been integrated in the EQCP study according to the three individual trials-(i) COPD exacerbation, (ii) PPF, and (iii) teamwork. This PhD dissertation is integrated in the study on COPD exacerbation and focusses on the first study objective: impact of care pathways for in-hospital management of COPD exacerbations on care processes and clinical outcomes. Thus, it should be noted that the team component is not addressed in this $\mathrm{PhD}$ dissertation but is studied in the other PhD dissertation on teamwork.

As described in Chapter 6, the EQCP study is being conducted in four countries (Belgium, Ireland, Italy, and Portugal). The Belgian EQCP study is one year ahead in 
accomplishing study aims compared to the other countries. The results of the three other countries are expected next year in spring 2013, with finalisation of the data analyses taking place in autumn 2013. Because of timing and feasibility, we decided not to delay the finalisation of this dissertation until the results from the four countries become available. Instead, we decided to limit the results section (Chapters 7 and 8) to those of the Belgian component of the EQCP study. The final results based on data from the four countries and the results answering the second research question ('why and under what circumstances do care pathways work?') will be analysed and reported by the EQCP research group, specifically in future publications and during conference reports in 2013 and 2014.

\section{Objectives and outline of the dissertation}

This PhD dissertation focusses on three main objectives: (i) describe the actual quality of care for patients hospitalised with COPD exacerbations; (ii) develop a methodology for international research on the impact of a COPD exacerbation care pathway on care processes and clinical outcomes; (iii) analyse interim data of the EQCP study collected in Belgian hospitals.

This dissertation addresses six research questions $(R Q)$ :

RQ1: What is the level of adherence to international guidelines with regard to care processes for in-hospital management of COPD exacerbations according to the literature?

RQ2: What is the impact of existing care pathways for in-hospital management of COPD exacerbations according to the literature?

RQ3: Which indicators should be followed up when evaluating the impact of a care pathway for COPD exacerbations?

RQ4: Which set of key interventions should be included in a care pathway for COPD exacerbations?

RQ5: What is the impact of a care pathway for in-hospital management of COPD exacerbations on performance of care processes and clinical outcomes?

RQ6: What is the level of implementation of the key interventions included as active components in a care pathway for in-hospital management of COPD exacerbations?

This dissertation is a compilation of published research articles and pre-published manuscripts. The following section provides an overview of the dissertation. 
In Chapter 2, a literature review on the quality of in-hospital management of COPD exacerbations is presented. This chapter is published in the Journal of Evaluation in Clinical Practice.

Chapter 3 is a literature review on the characteristics of existing care pathways for inhospital management of COPD exacerbations and their impact on performance of care processes, clinical outcomes, and team functioning. This chapter is published in the International Journal of Nursing Studies.

Chapter 4 presents the methodology and results of a Delphi survey conducted to select process and outcome indicators for follow-up of care for patients hospitalised with COPD exacerbations. This chapter is published in the Journal of Advanced Nursing.

Chapter 5 presents the methodology and results on how to build the clinical content of an evidence-based care pathway for COPD exacerbations. This chapter has been submitted for publication.

In Chapter 6, the design and rationale of a phase III trial including an international CRCT on the impact of care pathways for in-hospital management of COPD exacerbations is presented. This chapter is published in Trials.

Chapter 7 reports the preliminary results of the CRCT on the effectiveness of a care pathway for COPD exacerbations. This chapter includes the results of the Belgian EQCP study.

In Chapter 8, an implementation analyses in the Belgian experimental hospitals is presented. This chapter explores the level of implementation of the key interventions included as active components in the care pathway for in-hospital management of COPD exacerbations.

Chapter 9 starts with an overview of the main findings of the dissertation. Next, methodological limitations are addressed. Subsequently, implications for organisation of COPD care and recommendations for research are addressed. Finally, a general conclusion is formulated. Part of this discussion is published in the International Journal of Integrated Care Pathways. 


\section{References}

1 Burge S, Wedzicha JA. COPD exacerbations: definitions and classifications. Eur Respir J Suppl 2003;41:46s-53s.

2 Calverly P, Georgopoulos D. Chronic obstructive pulmonary disease: symptoms and signs. In Siafkas N, (ed): Management of Chronic Obstructive Pulmonary Disease. European Respiratory Monograph. Sheffield, European Respiratory Society Journals Ltd, 2006, vol 11, pp 8-23.

3 Global Initiative for Chronic Obstructive Lung Disease. Global strategy for the diagnosis, management, and prevention of chronic obstructive pulmonary disease, updated 2010. [http://www.goldcopd.org/uploads/users/files/GOLD_Report_2011Dec30.pdf]

4 Siafkas N. Definition and differential diagnosis of chronic obstructive pulmonary disease. In Siafkas N, (ed): Management of Chronic Obstructive Pulmonary Disease. European Respiratory Monograph. Sheffield, European Respiratory Society Journals Ltd, 2006, vol 11, pp 1-6.

5 Annesi-Maesano I. Epidemiology of chronic obstructive pulmonary disease; Management of Chronic Obstructive Pulmonary Disease.European Respiratory Monograph. Sheffield, European Respiratory Society Journals Ltd, 2006, vol 11, pp 4370.

6 Halbert RJ, Natoli JL, Gano A, Badamgarav E, Buist AS, Mannino DM. Global burden of COPD: systematic review and meta-analysis. Eur Respir J 2006;28:523-532.

7 World Health Organization. WHO report on the global tobacco epidemic, 2011: Warning about the dangers of tobacco; 2011. [http://www.who.int/tobacco/global_report/2011/en/]

8 Feenstra TL, van Genugten ML, Hoogenveen RT, Wouters EF, Rutten-van Molken MP. The impact of aging and smoking on the future burden of chronic obstructive pulmonary disease: a model analysis in the Netherlands. Am J Respir Crit Care Med 2001;164:590596.

9 Lopez AD, Shibuya K, Rao C, Mathers CD, Hansell AL, Held LS, Schmid V, Buist S. Chronic obstructive pulmonary disease: current burden and future projections. Eur Respir J 2006;27:397-412.

10 Murray CJ, Lopez AD. Alternative projections of mortality and disability by cause 19902020: Global Burden of Disease Study. Lancet 1997;349:1498-1504.

11 European Respiratory Society. European Respiratory Roadmap: Recommendations for the future respiratory medicine; 2011.

12 Mannino DM, Buist AS. Global burden of COPD: risk factors, prevalence, and future trends. Lancet 2007;370:765-773.

13 World Health Organization. Top Ten Causes of Death. Fact Sheet no. 310; 2008. [http://www.who.int/mediacentre/factsheets/fs310/en/index.html] 
14 Vestbo J. Socioeconomic burden of chronic obstructive pulmonary disease. In Siafkas N, (ed): Management of Chronic Obstructive Pulmonary Disease. European Respiratory Monograph. Sheffield, European Respiratory Society Journals Ltd, 2006, vol 11, pp 463469.

15 Halpin DM, Miravitlles M. Chronic obstructive pulmonary disease: the disease and its burden to society. Proc Am Thorac Soc 2006;3:619-623.

16 Wouters EF. Economic analysis of the Confronting COPD survey: an overview of results. Respir Med 2003;97 Suppl C:S3-14.

17 Chapman KR, Mannino DM, Soriano JB, Vermeire PA, Buist AS, Thun MJ, Connell C, Jemal A, Lee TA, Miravitlles M, Aldington S, Beasley R. Epidemiology and costs of chronic obstructive pulmonary disease. Eur Respir J 2006;27:188-207.

18 Harvard School of Public Health. Costly Non communicable Disases on rise in developing world; 2011.

[http://www3.weforum.org/docs/WEF_Harvard_HE_GlobalEconomicBurdenNonCommun icableDiseases_2011.pdf]

19 Chenna PR, Mannino DM. Outcomes of severe COPD exacerbations requiring hospitalization. Semin Respir Crit Care Med 2010;31:286-294.

20 Izquierdo JL, Barcina C, Jimenez J, Munoz M, Leal M. Study of the burden on patients with chronic obstructive pulmonary disease. Int J Clin Pract 2009;63:87-97.

21 Seemungal TA, Hurst JR, Wedzicha JA. Exacerbation rate, health status and mortality in COPD--a review of potential interventions. Int J Chron Obstruct Pulmon Dis 2009;4:203223.

22 Siafkas N, Wedzicha J. Management of acute exacerbation of chronic obstructive pulmonary disease; in Siafkas N, (ed): Management of chronic obstructive pulmonary disease.European Respiratory Monograph. Sheffield, European Respiratory Society Ltd, 2006, vol 11, pp 387-400.

23 Cao Z, Ong KC, Eng P, Tan WC, Ng TP. Frequent hospital readmissions for acute exacerbation of COPD and their associated factors. Respirology 2006;11:188-195.

24 Garcia-Aymerich J, Farrero E, Felez MA, Izquierdo J, Marrades RM, Anto JM. Risk factors of readmission to hospital for a COPD exacerbation: a prospective study. Thorax 2003;58:100-105.

25 Toy EL, Gallagher KF, Stanley EL, Swensen AR, Duh MS. The economic impact of exacerbations of chronic obstructive pulmonary disease and exacerbation definition: a review. COPD 2010;7:214-228.

26 Miravitlles M, Murio C, Guerrero T, Gisbert R. Costs of chronic bronchitis and COPD: a 1-year follow-up study. Chest 2003;123:784-791. 
27 Geitona M, Hatzikou M, Steiropoulos P, Alexopoulos EC, Bouros D. The cost of COPD exacerbations: a university hospital--based study in Greece. Respir Med 2011;105:402409.

28 Bourbeau J. Activities of life: the COPD patient. COPD 2009;6:192-200.

29 Wang Q, Bourbeau J. Outcomes and health-related quality of life following hospitalization for an acute exacerbation of COPD. Respirology 2005;10:334-340.

30 Groenewegen $\mathrm{KH}$, Schols AM, Wouters EF. Mortality and mortality-related factors after hospitalization for acute exacerbation of COPD. Chest 2003;124:459-467.

31 Yohannes AM, Baldwin RC, Connolly MJ. Predictors of 1-year mortality in patients discharged from hospital following acute exacerbation of chronic obstructive pulmonary disease. Age Ageing 2005;34:491-496.

32 Sethi S, File TM. Managing patients with recurrent acute exacerbations of chronic bronchitis: a common clinical problem. Curr Med Res Opin 2004;20:1511-1521.

33 Ram FS, Wedzicha JA, Wright J, Greenstone M. Hospital at home for patients with acute exacerbations of chronic obstructive pulmonary disease: systematic review of evidence. BMJ 2004;329:315.

34 Hernandez C, Casas A, Escarrabill J, Alonso J, Puig-Junoy J, Farrero E, Vilagut G, Collvinent B, Rodriguez-Roisin R, Roca J. Home hospitalisation of exacerbated chronic obstructive pulmonary disease patients. Eur Respir J 2003;21:58-67.

35 Casas A, Troosters T, Garcia-Aymerich J, Roca J, Hernandez C, Alonso A, del PF, de TP, Anto JM, Rodriguez-Roisin R, Decramer M. Integrated care prevents hospitalisations for exacerbations in COPD patients. Eur Respir J 2006;28:123-130.

36 Connors AF, Jr., Dawson NV, Thomas C, Harrell FE, Jr., Desbiens N, Fulkerson WJ, Kussin P, Bellamy P, Goldman L, Knaus WA. Outcomes following acute exacerbation of severe chronic obstructive lung disease. The SUPPORT investigators (Study to Understand Prognoses and Preferences for Outcomes and Risks of Treatments). Am J Respir Crit Care Med 1996;154:959-967.

37 National Institute for Health and Clinical Excellence (NICE). Chronic obstructive pulmonary disease - Management of chronic obstructive pulmonary disease in adults in primary and secondary care; 2010.

[http://www.nice.org.uk/nicemedia/live/13029/49397/49397.pdf]

38 Shepperd S, Harwood D, Gray A, Vessey M, Morgan P. Randomised controlled trial comparing hospital at home care with inpatient hospital care. II: cost minimisation analysis. BMJ 1998;316:1791-1796.

39 Pierson DJ. Clinical practice guidelines for chronic obstructive pulmonary disease: a review and comparison of current resources. Respir Care 2006;51:277-288. 
40 Celli BR, Macnee W. Standards for the diagnosis and treatment of patients with COPD: a summary of the ATS/ERS position paper. Eur Respir J 2004;23:932-946.

41 Kuzma AM, Meli Y, Meldrum C, Jellen P, Butler-Lebair M, Koczen-Doyle D, Rising P, Stavrolakes K, Brogan F. Multidisciplinary care of the patient with chronic obstructive pulmonary disease. Proc Am Thorac Soc 2008;5:567-571.

42 Siafkas N. Management of chronic obstructive pulmonary disease. Sheffield, European Respiratory Society Ltd, 2006.

43 Campbell H, Hotchkiss R, Bradshaw N, Porteous M. Integrated care pathways. BMJ 1998;316:133-137.

44 Panella M, Marchisio S, Di SF. Reducing clinical variations with clinical pathways: do pathways work? Int J Qual Health Care 2003;15:509-521.

45 Pearson SD, Goulart-Fisher D, Lee TH. Critical pathways as a strategy for improving care: problems and potential. Ann Intern Med 1995;123:941-948.

46 Sermeus W, De Bleser L, Depreitere R, Dewaele K, Vanhaecht k, Vlayen J: An introduction to clinical pathways. In Devriese S, Lambert M, Eyssen M, Van de Sande S, Poelmans J, Van Brabandt H, Sermeus W, Vlayen J, Ramaekers D, (eds): The use of clinical pathways and guidelines to determine physicians' hospital fees prospectively: easier said than done.T. Brussels, Belgian Healthcare Knowledge Centre (KCE). KCE Reports, Volume 18A, 2005. [http:/www.kenniscentrum.fgov.be/nl/publicaties.html, 2005]

47 Vanhaecht K, Bollman M, Bower K, Gallagher C, Gardine A, Guezo J, Jansen U, Massoud R, Moody K, Sermeus W, Van Zelm R, Whittle C, Yazbeck A, Zander K, Massimilian P: Prevalence and use of clinal pathways in 23 countries - an internation survey by the European Pathway Association (www.E-P-A-.org). Intl J Care Pathw 2006;10:28-34.

48 Vanhaecht K, De Witte K, Sermeus W. The Care Process Organisation Triangle: A framework to better understand how clinical pathways work. Intl J Care Pathw 2007;11:1-8.

49 Vanhaecht K, Panella M, Van Zelm R, Sermeus W. Is there a future for care pathways? Five pieces to the puzzle. Intl J Care Pathw 2009;13.

50 Zander K, Bower K. Implementing strategies for managing care. Boston, 2000.

51 Panella $\mathrm{M}$, Vanhaecht $\mathrm{K}$. Is there still need for confusion about pathways? Intl J Care Pathw 2010;14:1-3.

52 Vanhaecht K, Ovretveit J, Elliott MJ, Sermeus W, Ellershaw J, Panella M. Have we drawn the wrong conclusions about the value of care pathways? Is a Cochrane review appropriate? Eval Health Prof 2012;35:28-42.

53 Vleugels A. Why pathways cannot taken of the shelf. Intl J Care Pathw 2009;14:150154. 
54 Harkleroad A, Schirf D, Volpe J, Holm MB. Critical pathway development: an integrative literature review. Am J Occup Ther 2000;54:148-154.

55 Vanhaecht K, Deneckere S, Van Gerven E, Lodewijckx C, Janssens I, Van Zelm R, Boto $P$, Panella M, Biringer E, Sermeus W. The 7-phase method to design, implement and evaluate care pathways. International Journal of Person Centered Medicine 2011. In press.

56 Deming W. Out of the Crisis; Cambridge, Massachusetts Institute of Techonolgy, Center for Advanced Engineering Study, 1993.

57 Panella M, Brambilla R, Marchisio S, Di SF. Reducing Stroke In-Hospital Mortality: Organized Care Is a Complex Intervention. Stroke 2008;39:e186.

58 Vanhaecht K. Comment on: What is a clinical pathway? Development of a definition to inform the debate. BMC Medicine 2010;8. [http://www.biomedcentral.com/17417015/8/31]

59 Medical Research Council. A Framework for development and evaluation of RCTs for Complex Interventions to Improve Health; 2000. [http://www.mrc.ac.uk/Utilities/Documentrecord/index.htm?d=MRC003372]

60 Medical Research Council (2008). Developing and evaluating complex interventions: new guidance, 2008.

[http://www.mrc.ac.uk/Utilities/Documentrecord/index.htm?d=MRC004871]

61 Berwick DM. The science of improvement. JAMA 2008;299:1182-1184.

62 Campbell NC, Murray E, Darbyshire J, Emery J, Farmer A, Griffiths F, Guthrie B, Lester $\mathrm{H}$, Wilson $\mathrm{P}$, Kinmonth $\mathrm{AL}$. Designing and evaluating complex interventions to improve health care. BMJ 2007;334:455-459.

63 Campbell M, Fitzpatrick R, Haines A, Kinmonth AL, Sandercock P, Spiegelhalter D, Tyrer P. Framework for design and evaluation of complex interventions to improve health. BMJ 2000;321:694-696.

64 Craig P, Dieppe P, Macintyre S, Michie S, Nazareth I, Petticrew M. Developing and evaluating complex interventions: the new Medical Research Council guidance. BMJ 2008;337:a1655.

65 Hardeman W, Sutton S, Griffin S, Johnston M, White A, Wareham NJ, Kinmonth AL. A causal modelling approach to the development of theory-based behaviour change programmes for trial evaluation. Health Educ Res 2005;20:676-687.

66 Oakley A, Strange V, Bonell C, Allen E, Stephenson J. Process evaluation in randomised controlled trials of complex interventions. BMJ 2006;332:413-416.

67 Campbell MJ, Donner A, Klar N. Developments in cluster randomized trials and Statistics in Medicine. Stat Med 2007;26:2-19. 
68 Shiell A, Hawe P, Gold L. Complex interventions or complex systems? Implications for health economic evaluation. BMJ 2008;336:1281-1283.

69 Bandolier. Independent evidence-based health care. On Care pathways.; 2003. [http://www.medicine.ox.ac.uk/bandolier/extraforbando/forum2.pdf]

70 Rotter T, Kinsman L, James E, Machotta A, Gothe H, Willis J, Snow P, Kugler J. Clinical pathways: effects on professional practice, patient outcomes, length of stay and hospital costs. Cochrane Database Syst Rev 2010;3:CD006632.

71 Van Herck P, Vanhaecht K, Sermeus W. Effects of Clinical Pathways: do they work? Journal of Integrated Care Pathways. Intl J Care Pathw 2004;8:95-105.

72 Medical Research Council (MRC). Cluster Randomised Trials: Methodological and ethical considerations. Medical Research Council (MRC) 2002.

73 Panella M, Marchisio S, Barbieri A, Di SF. A cluster randomized trial to assess the impact of clinical pathways for patients with stroke: rationale and design of the Clinical Pathways for Effective and Appropriate Care Study [NCT00673491]. BMC Health Serv Res 2008;8:223.

74 Panella M, Marchisio S, Demarchi ML, Manzoli L, Di SF. Reduced in-hospital mortality for heart failure with clinical pathways: the results of a cluster randomised controlled trial. Qual Saf Health Care 2009;18:369-373.

75 Scales DC, Dainty K, Hales B, Pinto R, Fowler RA, Adhikari NK, Zwarenstein M. A multifaceted intervention for quality improvement in a network of intensive care units: a cluster randomized trial. JAMA 2011;305:363-372.

76 Cunningham S, Logan C, Lockerbie L, Dunn MJ, McMurray A, Prescott RJ. Effect of an integrated care pathway on acute asthma/wheeze in children attending hospital: cluster randomized trial. J Pediatr 2008;152:315-320.

77 De Luca A, Toni D, Lauria L, Sacchetti ML, Giorgi RP, Ferri M, Puca E, Prencipe M, Guasticchi G. An emergency clinical pathway for stroke patients--results of a cluster randomised trial (isrctn41456865). BMC Health Serv Res 2009;9:14.

78 Kinsman LD, Rotter T, Willis J, Snow PC, Buykx P, Humphreys JS. Do clinical pathways enhance access to evidence-based acute myocardial infarction treatment in rural emergency departments? Aust J Rural Health 2012;20:59-66.

79 Cook DA, Beckman TJ. Reflections on experimental research in medical education. Adv Health Sci Educ Theory Pract 2008.

80 Polit D, Hungler B. Research Designs for Quantitative studies. In Polit D, Hungler B, (eds): Nursing Research: Principles and methods. Philadelphia, Lippincot Williams \& Wilkins, 1997, pp 175-218. 
81 Trochim W. Single Group Threats. In Research Methods Knowledge Base (Trochim W, ed.), Cornell University Cornell University, 2006. [http://www.socialresearchmethods.net/kb/intsing.php]

82 Trowbridge R, Weingarten S. Making health care safer, a critical analysis of patient safety practices.; 2001.

83 Holmboe ES, Meehan TP, Radford MJ, Wang Y, Marciniak TA, Krumholz HM. Use of critical pathways to improve the care of patients with acute myocardial infarction. Am J Med 1999;107:324-331.

84 Vanhaecht K, Sermeus W, Peers J, Deneckere S, Lodewijckx C, Leigheb F, Panella M. The European Quality of Care Pathways (EQCP) Study: history, project managment and approach. Intl J Care Pathw 2010;14:52-56.

85 Vanhaecht K, Sermeus W, Peers J, Lodewijckx C, Deneckere S, Leigheb F, Decramer M, Panella M. The impact of care pathways for exacerbation of Chronic Obstructive Pulmonary Disease: rationale and design of a cluster randomized controlled trial. Trials 2010;11:111.

86 Vanhaecht K, Sermeus W, Peers J, Lodewijckx C, Deneckere S, Leigheb F, Boonen S, Sermon A, Boto $P$, Mendes R, Panella M. The impact of care pathways for exacerbation of Proximal Femure Fracture: rationale and design of a cluster randomized controlled trial. Trials 2012;11:111.

87 Deneckere S, Euwema M, Lodewijckx C, Panella M, Sermeus W, Vanhaecht K. The European quality of care pathways (EQCP) study on the impact of care pathways on interprofessional teamwork in an acute hospital setting: study protocol: for a cluster randomised controlled trial and evaluation of implementation processes. Implement Sci 2012;7:47. 


\section{Chapter 2:}

In-hospital management of COPD exacerbations: a systematic review of the literature with regard to adherence to international guidelines

This chapter is published and reproduced with the kind permission of the editor:

Lodewijckx C, Sermeus W, Vanhaecht K, Deneckere S, Leigheb F, Panella M, Decramer M. In-hospital management of COPD exacerbations: a systematic review of the literature with regard to adherence to international guidelines. J Eval Clin Pract 2009;15:1101-10. 


\begin{abstract}
Background. Chronic obstructive pulmonary disease (COPD) exacerbations are a leading cause of hospitalisation. Suboptimal in-hospital management is expected to lead to more frequent exacerbations and recurrent hospital admission, and is associated with increased mortality.
\end{abstract}

Objective. To explore in-hospital management of COPD and to compare the results with recommendations from international guidelines.

Methods. A literature search was carried out for relevant articles published 2000-2009 in the databases Medline, Cochrane Library, Cumulative Index for Nursing and Allied Health Literature and Invert. In addition, the reference lists of the selected articles were examined. Main inclusion criteria were as follows: COPD, exacerbation, hospitalisation, description of inpatient management, and clinical trials. Assessment and treatment strategies in different studies were analysed and compared with American Thoracic Society-European Respiratory Society and Global Initiative for Chronic Obstructive Lung Disease guidelines. Outcomes were analysed.

Results. Seven eligible studies were selected. Non-pharmacological treatment was infrequently explored. When compared with international guidelines, diagnostic assessment and therapy were suboptimal, especially non-pharmacological treatment. Respiratory physicians were more likely to perform recommended interventions than non-respiratory physicians.

Conclusions. Adherence to international guidelines is low for in-hospital management of COPD exacerbations, especially in terms of non-pharmacological treatment. Further investigation is recommended to explore strategies like care pathways that improve performance of recommended interventions. 


\section{Introduction}

Chronic obstructive pulmonary disease (COPD) is associated with frequent exacerbations [1;2]. A prospective clinical trial demonstrated that some patients with moderate to severe COPD have three or more exacerbations a year [2]. A COPD exacerbation is characterized by a change in baseline dyspnoea, cough, and/or sputum that is beyond normal day-to-day variations, that is acute in onset, and that may warrant additional treatment in a patient with underlying COPD [3].

Worldwide, COPD exacerbations are a leading cause of acute hospital admission [1;4-8]. An audit of hospital readmissions in 1400 patients showed that around $30 \%$ of patients presenting with a first exacerbation will be readmitted with another event within 8 weeks [7]. In addition, COPD exacerbations have a serious negative impact on a patient's quality of life [9-11], and causes socioeconomic burden in terms of direct costs (costs related to medical goods and services) and indirect costs (lost work and productivity) [8]. Management of exacerbations should therefore focus on prevention and reduction of COPD exacerbations, with the ultimate aim of achieving quality of life after exacerbation and reducing health care resource utilization.

Suboptimal therapy for COPD is expected to lead to more frequent exacerbations and consequently recurrent hospitalisation. In addition, it is associated with patient errors, sometimes leading to a worsening condition, cardiopulmonary arrest, and death [12]. Several international clinical practice guidelines (CPGs) for the assessment and management of patients with COPD are available. These CPGs propose practices aimed at reducing COPD exacerbations. CPGs most important to clinicians are those from the American Thoracic Society-European Respiratory Society (ATS-ERS), the Global Initiative for Chronic Obstructive Lung Disease (GOLD), and the British National Collaborating Centre for Clinical Excellence. These CPGs are remarkably consistent and have very few areas of clinically relevant variation [13].

The aim of this literature review is to explore in-hospital management of COPD and to compare the findings of our review with international guideline recommendations.

\section{Methods}

The methodology used for this review is based on systematic review methods developed by the Cochrane Collaboration and the NHS Centre for Reviews and Dissemination [14].

\section{Search methods}

First, to identify relevant articles published between January 2000 and March 2009, we searched electronic databases - Medline, Cochrane Library, Cumulative Index for Nursing 
and Allied Health Literature, and Invert - using the Medical subject hearing terms COPD, exacerbation, hospitalisation, adherence, management and guideline. Second, we examined the reference lists of selected articles. Finally, we screened the selected articles to determine whether they met the following inclusion criteria: (i) report of original research; (ii) patients hospitalised for a COPD exacerbation; (iii) description of the assessment and treatment of a COPD exacerbation; (iv) clinical trials; and (iv) published in English, Dutch, French or German

\section{Search outcome}

The literature search initially identified 18 eligible studies that fulfilled the search criteria. After reading the full texts with regard to inclusion criteria and quality assessment, we included seven papers for further analysis (Table 1) [15-21].

\section{Quality appraisal}

For the quality appraisal of the studies, the list for assessment of observational studies described by the Centre for Reviews and Dissemination was used [22]. The following criteria were assessed: (i) appropriateness of methodology (sampling method, data collection method, and statistics); (ii) description of the groups and distribution of prognostic factors; (iii) description of the content and prevalence of the performed diagnostic and treatment interventions; (iv) generalizability of the results; and (v) limitations of the studies.

\section{Data synthesis}

We conducted a descriptive data synthesis and assessed heterogeneity. The data synthesis in this review follows Centre for Reviews and Dissemination procedures [23]. Study characteristics (sample size, setting, aim), assessment, treatment interventions and outcomes were tabulated and compared. The sample sizes of the selected studies varied widely; therefore, we included both percentages and corresponding proportions in presenting the results to assist the reader in making a judgment where studies conflict.

\section{Results}

\section{Study characteristics}

The selected articles were published between 2001 and 2007, and the studies were conducted between 1997 and 2004. The characteristics of each study are displayed in Table 1. The seven studies employed an observational design. Data were retrospectively collected by reviewing medical records. Only Cydulka et al. (2003) gathered data prospectively [17]. Four studies were multicentre trials, with sample sizes ranging from 397 to 69820 patients in 
29-360 hospitals [15;17;20;21]. In the three remaining monocentre studies, sample sizes ranged from 50 to 94 patients [16;18;19]. Six studies analysed the entire hospitalisation period, while the study of Cydulka et al. (2003) focused on management in the emergency department [17].

Patients were selected by convenience sampling in six studies, in which all patients consecutively admitted with a COPD exacerbation were included. Bratzler et al. (2004) used computerized random sampling for medical record selection [15]. Results were usually reported as percentages. However, two studies presented variations between hospitals by using interquartile range (IQR) and range of hospital percentages. P-values from Chi-square tests and $95 \%$ confidence intervals were calculated.

Six of seven studies explicitly stated that patients were hospitalised for a COPD exacerbation by listing the ICD code and by describing symptoms of increased breathlessness, increased sputum volume, increased sputum purulence, and worsening cough [15-17;19;21]. Kelly and Elborn (2002) defined three of these symptoms using the Anthonisen criteria, a classification scheme widely used for diagnosing acute exacerbations of COPD [19;24]. Cydulka et al. (2003) also included patients with mixed asthma/COPD (44\%), but all patients were admitted for COPD exacerbation [17].

Table 1. Overview of 7 papers analysed in the present review

\begin{tabular}{|c|c|c|c|c|}
\hline Author & $\begin{array}{l}\text { Study } \\
\text { period }\end{array}$ & Setting & $\begin{array}{l}\text { Patient } \\
\text { sample }\end{array}$ & Design \\
\hline $\begin{array}{l}\text { Roberts et al. } \\
\text { (2001) [21] }\end{array}$ & 1997 & $\begin{array}{l}\mathrm{n}=43 \text {; UK hospitals with } \\
\text { acute respiratory department: } \\
14 \text { university teaching } \\
\text { hospitals and } 29 \text { district } \\
\text { hospitals }\end{array}$ & $\mathrm{n}=1400$ & $\begin{array}{l}\text { Multicentre retrospective } \\
\text { observational study: } \\
\text { medical record audit }\end{array}$ \\
\hline $\begin{array}{l}\text { Kelly \& Elborn } \\
(2002)[19]\end{array}$ & 1998 & $n=1$; Belfast City Hospital & $\mathrm{n}=50$ & $\begin{array}{l}\text { Retrospective observational } \\
\text { study: medical record audit }\end{array}$ \\
\hline $\begin{array}{l}\text { Cydulka et al. } \\
(2003)[17]\end{array}$ & $\begin{array}{l}1999- \\
2001\end{array}$ & $\begin{array}{l}\mathrm{n}=29 ; \text { emergency } \\
\text { departments in } 15 \text { US states } \\
\text { and } 3 \text { Canadian provinces }\end{array}$ & $\mathrm{n}=397$ & $\begin{array}{l}\text { Multicentre prospective } \\
\text { observational study: chart } \\
\text { review, interview, telephone } \\
\text { interview (follow-up) }\end{array}$ \\
\hline $\begin{array}{l}\text { Bratzler et al. } \\
(2004)[15]\end{array}$ & $\begin{array}{l}2000- \\
2001\end{array}$ & $\begin{array}{l}\mathrm{n}=76 ; \text { US community } \\
\text { hospitals }\end{array}$ & $\mathrm{n}=409$ & $\begin{array}{l}\text { Multicentre retrospective } \\
\text { observational study: } \\
\text { medical record audit }\end{array}$ \\
\hline $\begin{array}{l}\text { Harvey et al. } \\
(2005)[18]\end{array}$ & 2001 & $\begin{array}{l}\mathrm{n}=1 ; \text { regional hospital, } \\
\text { metropolitan Melbourne }\end{array}$ & $\mathrm{n}=49$ & $\begin{array}{l}\text { Retrospective observational } \\
\text { study: medical record audit }\end{array}$ \\
\hline $\begin{array}{l}\text { Lindenauer et } \\
\text { al. (2006) [20] }\end{array}$ & 2001 & $\begin{array}{l}\mathrm{n}=360 ; \text { predominantly small- } \\
\text { to-medium-sized non- } \\
\text { teaching facilities, } \\
\text { representing all regions of } \\
\text { the United States }\end{array}$ & $\begin{array}{l}n=6982 \\
0\end{array}$ & $\begin{array}{l}\text { Multicentre retrospective } \\
\text { observational study: } \\
\text { medical record audit }\end{array}$ \\
\hline $\begin{array}{l}\text { Chang et al. } \\
(2007) \text { [16] }\end{array}$ & 2004 & $\begin{array}{l}\mathrm{n}=1 ; \text { secondary and tertiary } \\
\text { referral hospital, Central } \\
\text { North Island of New Zealand }\end{array}$ & $\mathrm{n}=94$ & $\begin{array}{l}\text { Retrospective observational } \\
\text { study: medical record audit }\end{array}$ \\
\hline
\end{tabular}

*Before and after study; only results of pre-test are included 


\section{Patient characteristics}

Patient characteristics are displayed in Table 2. Half of the patients were male. Mean age ranged from 70 to 74 years. The Kelly and Elborn study (2002) was the only study to define disease severity according to British Thoracic Society guidelines [25]: 32\% (16/50) of patients had mild COPD (50-80\% predicted forced expiratory volume in one second [FEV1]); $54 \%$ (27/50) had moderate COPD (30-49\% predicted FEV1); and 14\% (7/50) had severe COPD (<30\% predicted FEV1) [19]. Roberts et al. (2001) and Chang et al. (2007) reported both a median predicted FEV1 of $35 \%$ with ranges of $25-53 \%$ and $14-83 \%$ respectively [16;21]. Arterial blood gases (ABGs) were reported in three studies [15;19;21]: 12\% (6/50) to $16 \%(224 / 1400)$ of patients had a $\mathrm{pH}<7.35$ [19;21]; 32\% (16/50 and 456/1400) of patients had $\mathrm{PaCO} 2>6 \mathrm{kPa}$ [19;21]; $18 \%$ of patients (246/1400) had $\mathrm{PaO} 2<7.3 \mathrm{kPa}$ [21]; and 5.1\% (21/409 and 72/1400) of patients experienced respiratory failure at $\mathrm{pH}<7.26$ and $\mathrm{PaCO} 2>8$ $\mathrm{kPa}[15 ; 21]$.

Table 2. Patient characteristics at admission

\begin{tabular}{|c|c|c|c|c|c|c|c|}
\hline \multirow[t]{2}{*}{ Author } & \multirow[b]{2}{*}{$\begin{array}{c}\text { Patient } \\
\text { sample } \\
\text { n }\end{array}$} & \multicolumn{2}{|c|}{ Sex } & \multirow[b]{2}{*}{$\begin{array}{c}\text { Age } \\
\text { mean } \\
\text { years (SD) }\end{array}$} & \multicolumn{3}{|c|}{ Smoking status } \\
\hline & & $\begin{array}{c}\text { Male } \\
\%\end{array}$ & $\begin{array}{c}\text { Female } \\
\%\end{array}$ & & $\begin{array}{c}\text { Active } \\
\text { smoker } \\
\text { n (\%) }\end{array}$ & $\begin{array}{c}\text { Ex- } \\
\text { smoker } \\
\text { n (\%) }\end{array}$ & $\begin{array}{c}\text { Never } \\
\text { smoked } \\
\text { n (\%) }\end{array}$ \\
\hline $\begin{array}{l}\text { Roberts et al. } \\
(2001) \text { [21] }\end{array}$ & 1400 & 54.6 & 45.4 & $72(10)$ & $445(31.8)$ & $64(4.6)^{*}$ & \\
\hline $\begin{array}{l}\text { Kelly \& Elborn, } \\
2002 \text { [19] }\end{array}$ & 50 & 48.0 & 52.0 & $72(1)$ & $24(48.9)$ & $18(36.7)$ & 7 (14.3) \\
\hline $\begin{array}{l}\text { Cydulka et al. } \\
(2003)[17]\end{array}$ & 397 & 48.1 & 51.9 & $70(9)$ & & & \\
\hline $\begin{array}{l}\text { Bratzler et al. } \\
(2004)[15]\end{array}$ & 409 & 45.2 & 54.8 & $74(6)$ & 117 (28.6) & & \\
\hline $\begin{array}{l}\text { Harvey et al. } \\
(2005) \text { [18] }\end{array}$ & 49 & 53.1 & 46.9 & $72(10)$ & $10(20.4)$ & $35(71.4)$ & $4(8.2)$ \\
\hline $\begin{array}{l}\text { Lindenauer et } \\
\text { al. }(2006)[20]\end{array}$ & 69820 & 42.5 & 57.8 & $\begin{array}{l}70^{\dagger} \text { (IQR: } \\
61-78)\end{array}$ & & & \\
\hline $\begin{array}{l}\text { Chang et al. } \\
\text { (2007) [16] }\end{array}$ & 94 & 57.1 & 42.9 & $70(12)$ & $36(38.3)$ & $25(55.3)$ & $6(6.4)$ \\
\hline
\end{tabular}

${ }^{*}$ Ex-smokers for $\leq 3$ months.

${ }^{\dagger}$ Median age.

Regarding previous admissions before the index admission (first admission of the patient during the studied period), Roberts et al. (2001) detailed that $27 \%$ (384/1400) of patients had been admitted in the preceding 4 months prior to index admission [16]. Cydulka et al. (2003) mentioned that $42 \%(176 / 397)$ of patients were admitted within the previous year [17]. Six studies examined smoking status, with active smokers ranging from $20 \%$ to $49 \%$ (Table 2 ). Co-morbidity was mentioned by Chang et al. (2007) ( $n=94)$, Harvey et al. (2005) ( $n=49)$ and Lindenauer et al. (2006) ( $n=69820)$, with $70-80 \%$ of these patients having at least two co-morbidities [16;18;20]. The most reported co-morbid conditions were ischaemic heart 
disease (52\%, 49/94); hypertension (18-41\%, 17/94 and 28 626/69 820 respectively); diabetes 17-22\%, 16/94 and 15360/69820 respectively); malignancies (11-17\%, 7682/69 820 and 16/94 respectively); anxiety and depression (10-20\%, 6982/69820 and 19/94 respectively); and fluid and electrolyte disorders (18\%, 12 568/69 820) [16;20]. Only Chang et al. (2007) reported body mass index $(n=94$; mean body mass index: 24 ; range: $12.6-$ 52.3) [16].

\section{Diagnostic assessment}

Table 3. Diagnostic assessments during hospitalisation

\begin{tabular}{|c|c|c|c|c|c|c|}
\hline Author & $\begin{array}{c}\text { Patient } \\
\text { sample } \\
n\end{array}$ & $\begin{array}{l}\text { X-ray } \\
\text { n (\%) }\end{array}$ & $\begin{array}{l}\text { ABGs* } \\
\text { n (\%) }\end{array}$ & $\begin{array}{c}\text { Sputum } \\
\text { sample } \\
\text { n (\%) }\end{array}$ & $\begin{array}{l}\text { PEF } \\
\text { n (\%) }\end{array}$ & $\begin{array}{c}\text { Spirometry } \\
\text { n (\%) }\end{array}$ \\
\hline $\begin{array}{l}\text { Roberts et al. } \\
(2001) \text { [21] }\end{array}$ & 1400 & $916(65.4)$ & 1109 (79.2) & & $648(46.3)$ & \\
\hline $\begin{array}{l}\text { Kelly \& Elborn } \\
(2002)[19]\end{array}$ & 50 & $44(88.0)$ & $38(76.0)$ & $24(48.0)$ & $12(24.0)$ & $9(18.0)$ \\
\hline $\begin{array}{l}\text { Cydulka et al. } \\
\text { (2003) [17] }\end{array}$ & 397 & $346(87.1)$ & $191(48.1)$ & $28(7.1)$ & $\begin{array}{c}129 \\
(32.5)^{*}\end{array}$ & \\
\hline $\begin{array}{l}\text { Bratzler et al. } \\
\text { (2004) [15] }\end{array}$ & 409 & $396(96.8)$ & $180(44.0)$ & $31(7.6)$ & $20(4.9)$ & \\
\hline $\begin{array}{l}\text { Harvey et al. } \\
(2005) \text { [18] }\end{array}$ & 49 & & $41(83.7)$ & & & \\
\hline $\begin{array}{l}\text { Lindenauer et } \\
\text { al. (2006) [20] }\end{array}$ & 69820 & $66276(94.9)$ & 44762 (64.1) & $10051(14.4)$ & & 8354 (12.0) \\
\hline $\begin{array}{l}\text { Chang et al. } \\
(2007)[16]\end{array}$ & 94 & $89(94.7)$ & $66(70.2)$ & & & \\
\hline
\end{tabular}

${ }^{*} \mathrm{PEF}$ represented $90 \%$ of spirometry; only $10 \%$ of values were FEV1s.

ABGs, arterial blood gas values; FEV1, forced expiratory volume in one second; PEF, peak expiratory flow.

In the studies analysed, the diagnostic evaluation mainly included chest radiography (X-ray), ABGs, sputum testing, and spirometry (Table 3). The percentage of patients who received Xrays ranged from $87 \%$ to $97 \%$. The percentage reported in the Roberts et al. study (2001) $(65 \%)$ does not indicate the number of patients who received X-rays, but instead the number of patients in which the X-ray was evaluated by a doctor within 24 hours [21]. With the exception of Lindenauer et al. (2006) all studies indicated that ABGs included $\mathrm{pH}, \mathrm{PaCO}$, $\mathrm{PaO} 2$ analyses; three studies also included $\mathrm{SaO} 2$ in their $\mathrm{ABG}$ analyses [15;18;21]. ABGs were performed in $44-84 \%$ of patients, with performance rates varying $20 \%$ across the hospitals that participated in the Roberts et al. (2001) (IQR: 73-90; $n=43$ hospitals) and Lindenauer et al. (2006) (IQR: 52.0-77.0; $n=360$ hospitals) studies [20;21]. In the Roberts et al. study (2001), 34\% of patients (476/1400) who had their ABGs measured at admission also had their ABG measurements repeated within 24 hours of admission [21]. The range of repeat $A B G$ measurements across hospitals was 20\% (IQR: 19-44; $n=43$ hospitals). Moreover, ABGs were more likely to be repeated in acidotic patients [21]. Two studies measured oxygen saturation using oximetry; oxygen saturation ranged from $76 \%(311 / 409)$ to $94 \%(1316 / 1400)[15 ; 21]$. Sputum testing varied from $7 \%$ to $48 \%$, with Lindenauer et al. 
(2006) mentioning a variance of $30 \%$ across 360 hospitals (IQR: $0.0-29.0 ; n=360$ hospitals). In the five studies that measured performance of peak expiratory flow (PEF) and spirometry, 5 to $46 \%$ of the patients underwent one of these or both pulmonary function tests [15;17;19-21] (Table 3).

\section{Pharmacological treatment}

Pharmacological treatment included bronchodilators, corticosteroids and antibiotics (Table 4). Bronchodilator use (b-agonists and anticholinergics) ranged from $91 \%$ to $100 \%$. Four studies mentioned the route of administration [16;18;20;21]. Nebulizer use ranged from $32 \%$ (30/94) [16] to approximately $100 \%$ [18;20;21]. Two studies mentioned metered dose inhaler use, which ranged from $44 \%(10 / 94)$ to $60 \%$ (41 892/69 280) [16;20]. In most cases, corticosteroids were administered in $80-88 \%$ of patients [15;16;18-21][15,16,18-21]; however, in Cydulka et al. (2003) corticosteroid use was 62\% (Table 4) [17]. Only the study of Harvey et al. (2005) reported the duration of corticosteroid therapy, stating that $10 \%(5 / 49)$ of patients remained on therapy for $7-14$ days [18]. In five studies, $80-90 \%$ of patients received antibiotics. However, in Cydulka et al. (2003) only $28 \%$ of patients received antibiotics (Table 4) [17].

\section{Non-pharmacological treatment}

Non-pharmacological treatment included oxygen therapy, smoking cessation advice, education on inhaler therapy, referral to multidisciplinary disciplines, referral to pulmonary rehabilitation, discharge management, follow-up, assisted ventilation, and screening for vaccination. In four of seven studies, $64-90 \%$ of patients received oxygen therapy during admission (Table 4) [15;16;20;21]. Roberts et al. (2001) found that the percentage of patients receiving oxygen therapy varied by more than $20 \%$ across 43 hospitals (IQR: $53-77$ ), while Lindenauer et al. (2006) found that this percentage was comparable across 360 hospitals (IQR: 90-97) [20;21]. Roberts et al. (2001) observed that oxygen was more likely to be prescribed if a patient's $\mathrm{SaO} 2$ (measured by pulse oximetry) was less than $92 \%$; they found no obvious trend with $\mathrm{PaO} 2$ levels [21]. Chang et al. (2007) mentioned that the rationale for oxygen administration was poorly documented, and also found no correlation between initial supplemental oxygen administration and $\mathrm{SaO} 2(r=0.05)$ or ABG values $(r=0.16)$ [16].

Two studies reported that home oxygen therapy was prescribed at discharge, ranging from 18\% (252/1400) in Roberts et al. (2001) to 43\% (21/49) in Harvey et al. (2005) [18;21]. In Roberts et al. (2001) 18\% (246/1400) of patients had a PaO2 < $7.3 \mathrm{kPa}$ at admission, and only few of these (no exact number defined) had a subsequent $\mathrm{PaO} 2>7.3 \mathrm{kPa}$ while breathing room air. However, only $28 \%$ (68/246) of these patients were discharged with home oxygen therapy [21]. 


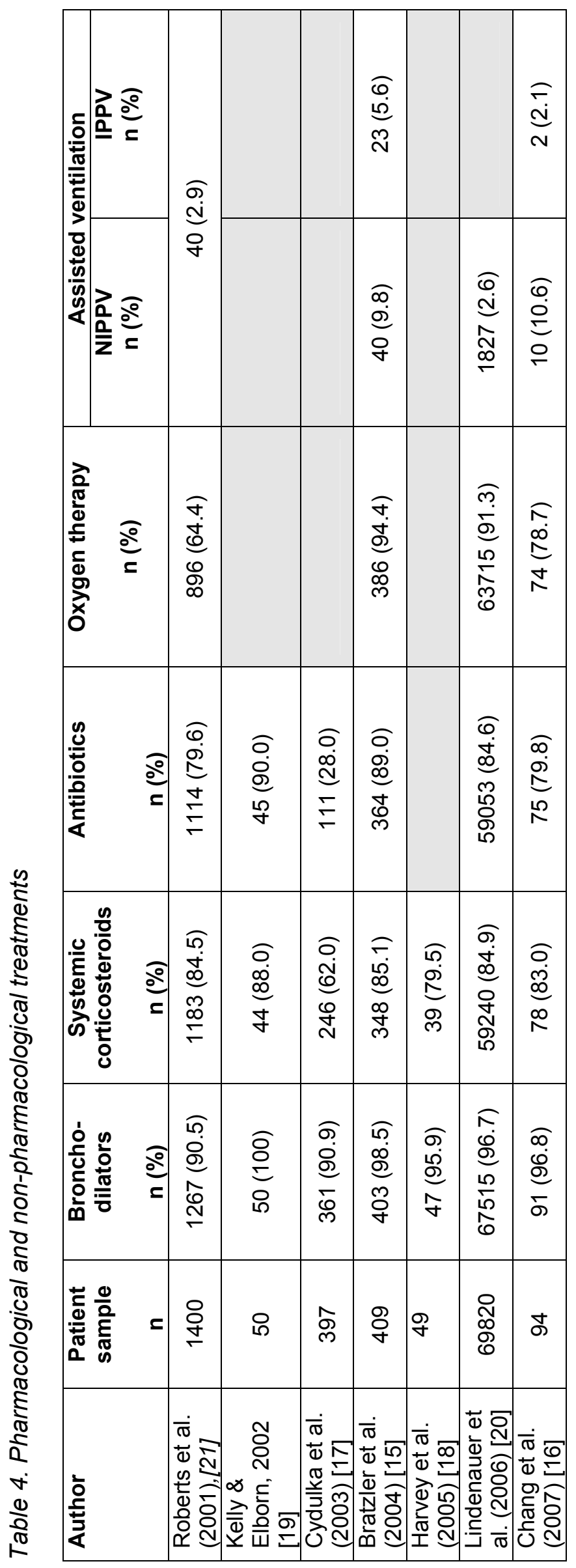


Only Roberts et al. (2001) mentioned education on inhaler therapy. Technique was checked in $20 \%$ of patients (280/1400) and was more likely to be checked during a patient's first admission rather than readmissions (28 vs. 16\%) [21].

Smoking cessation advice for active smokers was explored by three studies; the percentage of patients receiving this advice ranged from 30\% (134/445 current smokers) [21], and 34\% (40/117) [15], to 42\% (10/24) [19]. Moreover, Roberts et al. (2001) found that advice was more likely to be given on a patient's first admission rather than on readmissions (34 vs. $28 \%$ ) [21]. They also reported that smoking cessation advice was provided to $19 \%$ $(12 / 64)$ of patients who had quit smoking since 3 months or less before being hospitalised [21].

Referral to pulmonary rehabilitation was explored by three studies, with the percentage of patients receiving referrals ranging from $3 \%(42 / 1400)$ [21] and $16 \%(8 / 49)$ [18] to $18 \%(9 / 50)$ [19]. Two other studies mentioned referrals to other disciplines: physiotherapy (65\%, 61/94) [16]; a COPD nurse specialist (10-63\%, 5/50 and 59/94 respectively) [16;19]; and a dietician $(26 \%, 24 / 94)[16]$.

Three studies reported assessment of social situation, including living situation (i.e. living alone) [16;18]; social support system, access to telephone emergency contact, geographic remoteness and access to health care at home [16]; household income and whether or not having an medical assurance [17]. In Bratzler et al. (2004) 57\% $(n=409)$ of patients were discharged home without home care; $17 \%$ had home health care services arranged; $9 \%$ required skilled nursing or a swing bed; and $5 \%$ and $6 \%$ were discharged to a rehabilitation facility or a nursing home respectively [15]. Chang et al. (2007) found that 15\% (14/94) of patients previously living at home were discharged to residential care facilities [16]. Two studies reported that $38 \%(19 / 50)$ to $63 \%(882 / 1400)$ of patients received outpatient followup and review appointments [19;21].

Five studies found that $3-11 \%$ of patients received assisted ventilation via non-invasive positive pressure ventilation (NIPPV) (Table 4). Assisted ventilation was more likely to be initiated in patients with acidosis [16;18;21]. Bratzler et al. (2004) reported that 52\% $(213 / 409)$ of patients with $\mathrm{pH}<7.26$ and $\mathrm{PCO} 2>8 \mathrm{kPa}$ received non-invasive ventilation [16]. On the other hand, Roberts et al. (2001) reported that the following received assisted ventilation: $15.3 \%$ of patients $(11 / 77)$ with $\mathrm{pH}<7.26 ; 7.5 \%$ of patients $(34 / 456)$ with $\mathrm{PCO} 2>$ $6 \mathrm{kPa}$; and $12.7 \%$ of patients (25/179) with $\mathrm{pH}<7.35$ and $\mathrm{PCO} 2>6.0$ [21].

Only two studies examined whether COPD patients were screened for vaccinations. Bratzler et al. (2004) (2004) found that 47\% (192/409) of patients were screened for vaccinations, whereas Roberts et al. (2001) noted that only 5\% (70/1400) of patients received vaccination advice $[15 ; 21]$. 


\section{Respiratory vs. non-respiratory physicians}

Three studies compared patient management performed by respiratory physicians and nonrespiratory physicians [16;19;21].

Patients receiving care from respiratory physicians varied from 43\% (602/1400) [21] and $44 \%(22 / 50)$ [19] to $94 \%$ (88/94) [16]. In Roberts et al. (2001) the remaining patients were under care of a geriatrician $(20 \% ; 277 / 1400)$ or another specialty $(32 \% ; 450 / 1400)$. Roberts et al. (2001) observed that respiratory physicians, compared with non-respiratory physicians, significantly more performed FEV1 and PEF with a variance of $20 \%(P<0.001)$ [21]. They also assessed more often patients' inhaler technique (21\% vs. $14 \% ; P<0.001)$; provided more smoking advice to current smokers (36\% vs. $26 \%$; $P<0.03$ ); initiated more often home oxygen therapy $(24 \%$ vs. $14 \%)(P<0.001)$; and prescribed significantly more discharge medications (variances ranged between 10\% and 20\%). Respiratory physicians also arranged significantly more follow-up ( $73 \%$ vs. $46 \%$; $P<0.001)$, and assessed more often the reversibility of bronchodilators (33\% vs. $23 \%$; $P<0.001)$ and steroids $(10 \%$ vs. $4 \%$; $P<$ 0.001). Both respiratory and non-respiratory physicians referred patients to pulmonary rehabilitation to similar extents (5\% to 1\%) [21]. Chang et al. (2007) observed that patients admitted by non-respiratory specialists tended to have longer hospital stays (mean: 4.9 days vs. 3.3 days) [16]. However, Kelly and Elborn (2002) found no difference in length of stay (LOS), spirometry, radiographs performed, or in treatment administered [19].

\section{Outcomes}

Six studies computed the median LOS, which varied from 4 days [16;17;20], 5 days [15], and 6 days [19] to 8 days [21]. Lindenauer et al. (2006) and Kelly and Elborn (2002), respectively, reported that 25\% (17 455/69 820) and 44\% (22/50) of patients remained hospitalised for 7 days or longer [19;20]. Eleven per cent $(7750 / 69820)$ to $18 \%(70 / 397)$ of patients were readmitted within 14 days after discharge [17;20]; 17\% (12 009/69 820) to 27\% (112/409) patients were readmitted within 1 month after discharge [15;20]; and 43\% (176/409) of patients were readmitted 6 months after discharge [15]. Two per cent (8/409) to 5\% $(5 / 94$ and 1793/69 820) of patients died during hospital stay [15;16;20]; 8\% (33/409 and 8/94) died within 1 month after discharge [15;16]; and 24\% (98/409) to $31 \%(29 / 94)$ of patients died within 6 months to 1 year, respectively, after admission [15;16]. 


\section{Discussion}

Our literature search, which was aimed at exploring in-hospital management of COPD exacerbations, identified seven eligible trials for further in-depth analysis. Both ATS-ERS and GOLD guidelines were used as standards to discuss the in-hospital management of COPD exacerbation in the reviewed studies [26;27]. ATS and ERS separately published position papers on the management of COPD in 1995 [28;29]. A cooperative, the ATS-ERS task force, updated the position papers in 2004, resulting in the Standards for the Diagnosis and Treatments of Patients with COPD [26]. GOLD was set up by the US National Heart, Lung and Blood Institute and the World Health Organisation. This expert panel prepared a consensus report based on their review of existing COPD guidelines and new information on pathogenic mechanisms of COPD: 'The Global Strategy for the Diagnosis, Management and Prevention of COPD' [27]. The first report was published in 2001, and was updated in 2008. Table 5 displays the recommendations of both guidelines. Overall, our review of the seven eligible trials showed poor adherence to the international recommendations.

Table 5. Recommendations of ATS-ERS and GOLD guidelines for in-hospital management of an COPD exacerbation [26;27]

\begin{tabular}{|c|c|}
\hline ATS-ERS guidelines & GOLD quidelines \\
\hline \multicolumn{2}{|c|}{ Diagnostic assessment } \\
\hline \multicolumn{2}{|c|}{ History before exacerbation } \\
\hline \multicolumn{2}{|c|}{ Chest radiography } \\
\hline \multicolumn{2}{|c|}{ Arterial blood gases } \\
\hline Sputum testing in all patients & $\begin{array}{l}\text { Sputum testing: if an infectious exacerbation } \\
\text { does not respond to initial antibiotic treatment }\end{array}$ \\
\hline \multicolumn{2}{|c|}{ Electrocardiogram (ECG) } \\
\hline \multicolumn{2}{|c|}{ Assessment of nutritional status } \\
\hline \multicolumn{2}{|c|}{ Pharmacological treatment } \\
\hline \multicolumn{2}{|c|}{ Short-acting bronchodilators } \\
\hline \multicolumn{2}{|c|}{ Corticosteroids: $30-40 \mathrm{mg}$ for 7 to 10 days (GOLD) or 10 to 14 days (ATS-ERS) } \\
\hline $\begin{array}{l}\text { Antibiotics (based on local bacteria resistance } \\
\text { patterns) in the following cases: } \\
\text { - change in sputum characteristics (purulence } \\
\text { and/or volume) } \\
\text { - patients requiring special or care in an } \\
\text { intensive care unit }\end{array}$ & $\begin{array}{l}\text { Antibiotics in the following cases: } \\
\text { - Symtoms: increased sputum purulence, } \\
\text { increased dyspnoea and/or increased } \\
\text { sputum volume } \\
\text { - critically ill and needing mechanical support }\end{array}$ \\
\hline \multicolumn{2}{|c|}{ Non-pharmacological treatment } \\
\hline \multicolumn{2}{|c|}{ Controlled oxygen therapy } \\
\hline \multicolumn{2}{|c|}{ Education on inhaler therapy, coping with dyspnoea, and nature of COPD } \\
\hline \multicolumn{2}{|c|}{ Smoking cessation intervention } \\
\hline \multicolumn{2}{|c|}{ Nutritional support, if necessary } \\
\hline \multicolumn{2}{|c|}{ Physiotherapy } \\
\hline \multicolumn{2}{|c|}{ Referral to pulmonary rehabilitation } \\
\hline Screening for vaccination status not mentioned & $\begin{array}{l}\text { Screening for vaccination status (influenza, } \\
\text { pneumococcal vaccines) }\end{array}$ \\
\hline \multicolumn{2}{|c|}{ Discharge management } \\
\hline \multicolumn{2}{|c|}{ Follow-up appointment } \\
\hline $\begin{array}{r}\text { Non-invasive mechanical ventilation in moderate } \\
\qquad(\mathrm{PaCO} 2>6.0\end{array}$ & $\begin{array}{l}\text { severe acidosis }(\mathrm{pH}<7.35) \text { and/ or hypercapnia } \\
\text { a, } 45 \mathrm{~mm} \mathrm{Hg})\end{array}$ \\
\hline
\end{tabular}




\section{Methodological quality of the existing research}

To limit historical effects, only papers published since 2000 were included for review. Three of the trials reported in these papers used data collected in the late 1990s (Table 1). However, interventions explored in these studies have been internationally recognized as major key interventions since the 1990s, so we believe bias is minimal. Retrospective data collection could bias the accuracy of the results, especially with regard to nonpharmacological management, as those interventions are less likely to be documented and detailed in records. Sample sizes and statistics used in the studies guarantee reliability of the results. Diagnosis of COPD exacerbation was confirmed by explicit definition and ICD code in six of the seven studies.

\section{Demographic characteristics of the studied patients}

The studied patients were largely comparable with regard to gender, age and smoking status (Table 2). FEV1 values reported in three studies indicated that patients hospitalised with a COPD exacerbation were classified mainly as having moderate to severe COPD, according to GOLD spirometric classification scheme for COPD [16;19;21;27]. ABGs were largely comparable for the three studies in which $A B G$ s were assessed [15;19;21]. The number of active smokers (20-49\%; Table 2 ) is of concern, as smoking is the main cause of COPD and also an important prognostic factor for the disease [30;31].

\section{Diagnostic assessment}

According to ATS-ERS and GOLD guidelines, the major components of the in-hospital assessment of a COPD exacerbation are history before exacerbation, chest X-ray, ABGs, electrocardiogram, sputum testing, and assessment of nutritional status (Table 5) [26;27].

Regarding X-rays, we found that $5-13 \%$ of patients presenting with a COPD exacerbation did not receive a chest X-ray (Table 3 ). X-rays are very useful in identifying alternative diagnoses that can mimic the symptoms of an exacerbation [27].

Our literature review revealed that $A B G$ s are very rarely performed. Two of the reviewed studies reported that $A B G$ s were measured in less than $50 \%$ of patients; the other studies reported that $A B G$ s were measured in $64-84 \%$ of patients (Table 3 ). Failing to obtain patients' $A B G$ s may lead to suboptimal management, as $A B G$ values are an important determinant for initiating supplemental oxygen therapy, for prescribing assisted ventilation, and for prescribing home oxygen therapy [32;33].

Sputum stains and cultures are useful in identifying bacterial infections and in directing antibiotic therapy [34]. Performance of sputum tests was very low (7-48\% of patients were tested) (Table 3). ATS-ERS guidelines recommend sputum cultures for all patients hospitalised with an exacerbation, while GOLD guidelines only recommend sputum cultures 
and antibiograms for patients in which an infectious exacerbation does not respond to the initial antibiotic treatment (Table 5). Although ATS-ERS and GOLD guidelines are incongruent with respect to whether or not all patients need sputum testing, both guidelines do agree that, at a minimum, sputum cultures should be performed in patients with purulent sputum and/or before starting antibiotics therapy [26;27].

Our literature review also revealed that spirometry is seldom performed: $5-46 \%$ of patients were reported to undergo spirometry and/or PEF (Table 3). Both ATS-ERS and GOLD guidelines do not routinely recommend spirometric tests, because these tests are inaccurate during acute exacerbations and can even be difficult for a sick patient to perform properly properly [26;27;34]. However, measuring PEFs and especially FEV1s is beneficial in assessing the severity of an exacerbation [35-37].

Other recommended diagnostic interventions (Table 5) that were not or very rarely examined in the included studies will not be discussed.

In conclusion, the studies we analysed revealed that diagnostic assessments according to ATS-ERS and GOLD guidelines are suboptimally performed with regard to X-rays and ABGs.

\section{Pharmacological treatment}

Main pharmacological interventions examined by the studies included in the present review were administration of bronchodilators, corticosteroids and antibiotics, all key pharmacological medications according to ATS-ERS and GOLD guidelines (Table 5).

Adherence to bronchodilator therapy was high, ranging from $90 \%$ to $100 \%$. Bronchodilators were delivered by nebulizer in $80-98 \%$ of cases [18;20;21]. Both ERS and GOLD guidelines advice against the use of nebulizers and recommend use of metereddose inhalers and dry powder inhalers if possible [26;27]. Literature indicates that use of wet nebulizers are more expensive, require appropriate maintenance, and have many adverse effects (i.e. highly variance in performance, less adherence to therapy) [38;39].

Adherence to corticosteroid therapy, however, was less than optimal, as $15-40 \%$ of patients did not receive corticosteroid therapy (Table 4). Systemic glucocorticosteroids shorten recovery time, improve lung function (FEV1) and hypoxemia (PaO2), and may reduce the risk of early relapse, treatment failure, and length of hospital stay [40].

According to evidence and recommendations from ATS-ERS and GOLD guidelines, antibiotics should be given to patients with exacerbations that present with increased sputum purulence, and also show increased dyspnoea and or increased sputum volume (Table 5). Patients who are critically ill and who need mechanical support also should receive antibiotics [26;27;40]. In four studies in which the patients showed the three key symptoms [15;16;19;21], $80-90 \%$ of patients were treated with antibiotics; in Cydulka et al. (2003) only 
$28 \%$ of patients received antibiotics, even though $84 \%$ of the patients also presented with the three key symptoms [17].

In conclusion, adherence to ATS-ERS and GOLD guidelines for bronchodilator and antibiotic treatment was acceptable, while adherence to guidelines for corticosteroid treatment was suboptimal.

\section{Non-pharmacological treatment}

Non-pharmacological treatments comprise an essential part of treatment for exacerbations. However, we discovered that the use of non-pharmacological treatments was poorly studied by the reports we included in our review. In Cydulka et al. (2003) this may have to do with the fact that the study was focused on emergency department management only [17]. Table 5 lists the main nonpharmacological interventions recommended by ATS-ERS and GOLD guidelines [26;27].

Oxygen therapy is the treatment cornerstone for severe COPD exacerbations [41]. Administration of oxygen therapy was mentioned in four studies, and the percentage of patients prescribed oxygen therapy was rather high (Table 4). Appropriateness of oxygen prescriptions cannot be discussed, because the studies rarely reported the ABGs of patients that received oxygen. Only two studies examined the use of home oxygen therapy [18;21]. Furthermore, Roberts et al. (2001) reported that prescribing home oxygen was suboptimal and not adjusted according to low $\mathrm{PaO} 2$ values subsequent to the exacerbation [21].

Only one study, Roberts et al. (2001) examined education provided to patients, and found out that patient education was limited to inhalation therapy and was only given in $20 \%$ of patients [21]. This is a very concerning finding as inhaler therapy is a cornerstone in the management of COPD patients [42;43]. Yet adherence to inhaler therapy with regard to dose and inhaler technique in COPD patients has been shown to be very low [44;45], and research has demonstrated that education can have a large impact on patients' understanding of their medication regimen and on inhaler technique [44-46]. Smoking cessation advice was rarely provided, with only about one-third of active smokers receiving advice [15;19;21]. ATS-ERS and GOLD guidelines state that smokers should be offered the most intensive smoking cessation intervention feasible [26;27]. Ceasing to smoke can prevent or delay the development of airflow limitations or can reduce the progression of these limitations, and can have a substantial effect on subsequent mortality [30;31].

The study of Chang et al. (2007) noted a rather high referral rate for physiotherapy, at $65 \%$ [16]. Three other studies, stated that only $3-18 \%$ of patients were referred to pulmonary rehabilitation [18;19;21][. This finding is of concern, as COPD patients are markedly inactive during and after hospitalisation for an exacerbation, and patients who have low activity levels for 1 month after discharge are more likely to be readmitted within the following year [47]. 
Early outpatient pulmonary rehabilitation after hospitalisation for a COPD exacerbation is safe and results in clinically significant improvement in exercise capacity, health status, and health-related quality of life, and reduces the risk of hospital admission and mortality [48].

Assessment of patients' social situation and discharge management was not examined extensively; however, two included studies showed that a large number of patients (15-57\%) needed referral to home care or institutionalization after hospitalisation for exacerbation [15;16]. Also a study of Gruffydd-Jones et al. (2007) in patients discharged home after an exacerbation found that one-third of these patients were concerned about their social situation, especially with regard to care, housing, social benefits, and the health of their caregiver [49]. Roberts et al. (2001) and Kelly and Elborn (2002) reported that only 38-63\% of patients received outpatient follow-up [19;21], which contrasts with literature indicating that intensive outpatient follow-up significantly improves quality of life after hospitalisation for an acute exacerbation [50].

The NIPPV in patients with hypercapnic respiratory failure reduces the need for intubation and reduces mortality [51-55]. However, Bratzler et al. (2004) reported that only half of the patients with hypercapnic failure received NIPPV, and Roberts et al. (2001) reported that $15 \%$ or less of patients with acidosis or hypercapnia received assisted ventilation (NIPPV) or invasive positive pressure ventilation [15;21]. In conclusion, these results indicate that assisted ventilation is highly underutilized.

The main limitation of the assessment of non-pharmacological treatment is the limited quantity and quality of the data available. In general, non-pharmacological interventions recommended by international guidelines were rarely performed, according to the studies included in this review.

\section{Respiratory vs. non-respiratory physicians}

Roberts et al. (2001) showed that respiratory physicians are significantly more likely to provide optimal management than non-respiratory physicians, especially with regard to nonpharmacological management [21]. These findings are consistent with those of several other clinical trials [56-59], and encourage the involvement of a respiratory physician in the inhospital management of a COPD exacerbation.

\section{Length of stay, readmission and mortality}

In the studies included in the present review, the mean LOS decreased from 8 to 4 days with increasing year of publication, which suggests an overall trend of decreasing LOS for patients hospitalised for COPD exacerbations during the last decades.

Regarding readmission and mortality, the degree to which data could be pooled was restricted by the different reported measures of outcomes, but rates within the same intervals 
were similar. Readmission and mortality was high in the studied patients $[15-17 ; 20]$; however, similar rates were found in other outcome studies on COPD exacerbations [5;5964].

\section{The need for standardization of the care process}

Transparency and standardization of care processes is one of the main challenges for clinicians, managers and policy makers. With respect to the findings in this literature review, we see the need for more standardization in COPD care. One of the possibilities to reorganize the care process around patient needs for COPD is the development of a care pathway, also known as critical pathways or clinical pathways [65-71]. Care pathways are complex interventions for the mutual decision making and organisation of predictable care for a well-defined group of patients during a well defined period (http://www.E-P-A.org) $[66 ; 68 ; 71 ; 72]$. Although they are used worldwide [70], the knowledge on pathways on COPD is not found in literature. International knowledge sharing networks like the European Pathway Association and international respiratory societies should therefore not only focus on the clinical content of the COPD pathways but also on the organisation of the care process. These international societies should develop a list of evidence-based key interventions which should be included in every COPD pathway. Our research team is preparing an international cluster randomized trial to further explore and understand how pathways for COPD should be developed, implemented, evaluated and what their impact is on outcome, efficiency and multidisciplinary teamwork.

\section{Conclusions}

Overall adherence is poor with regard to international guidelines in in-hospital management of COPD exacerbations, especially for non-pharmacological therapy. Further investigation is recommended to investigate strategies that might improve adherence to CPGs and enhance the quality of care, e.g. through the implementation of a care pathway.

\section{Acknowledgements}

We acknowledge the supporting of the Clinical Research Fund of UZ Leuven, Belgium. We also acknowledge Pfizer Belgium, Pfizer Italy, Pfizer Ireland, and Pfizer Portugal, who supported this research by providing an unrestricted educational grant. The autonomy of EP-A and all involved academic institutions with regard to scientific independence and intellectual property on methodology is guaranteed 


\section{References}

1 Izquierdo JL, Barcina C, Jimenez J, Munoz M, Leal M. Study of the burden on patients with chronic obstructive pulmonary disease. Int J Clin Pract 2009;63:87-97.

2 Seemungal TA, Donaldson GC, Paul EA, Bestall JC, Jeffries DJ, Wedzicha JA. Effect of exacerbation on quality of life in patients with chronic obstructive pulmonary disease. Am J Respir Crit Care Med 1998;157:1418-1422.

3 Burge S, Wedzicha JA. COPD exacerbations: definitions and classifications. Eur Respir J Suppl 2003;41:46s-53s.

4 Cao Z, Ong KC, Eng P, Tan WC, Ng TP. Frequent hospital readmissions for acute exacerbation of COPD and their associated factors. Respirology 2006;11:188-195.

5 Garcia-Aymerich J, Farrero E, Felez MA, Izquierdo J, Marrades RM, Anto JM. Risk factors of readmission to hospital for a COPD exacerbation: a prospective study. Thorax 2003;58:100-105.

6 Gibson PG, Wlodarczyk JH, Wilson AJ, Sprogis A. Severe exacerbation of chronic obstructive airways disease: health resource use in general practice and hospital. J Qual Clin Pract 1998;18:125-133.

7 Roberts CM, Lowe D, Bucknall CE, Ryland I, Kelly Y, Pearson MG. Clinical audit indicators of outcome following admission to hospital with acute exacerbation of chronic obstructive pulmonary disease. Thorax 2002;57:137-141.

8 Wouters EF. Economic analysis of the Confronting COPD survey: an overview of results. Respir Med 2003;97 Suppl C:S3-14.

9 Doll H, Grey-Amante P, Duprat-Lomon I, Sagnier PP, Thate-Waschke I, Lorenz J, Rychlik R, Pfeil T. Quality of life in acute exacerbation of chronic bronchitis: results from a German population study. Respir Med 2002;96:39-51.

10 Llor C, Molina J, Naberan K, Cots JM, Ros F, Miravitlles M. Exacerbations worsen the quality of life of chronic obstructive pulmonary disease patients in primary healthcare. Int J Clin Pract 2008;62:585-592.

11 Wang Q, Bourbeau J. Outcomes and health-related quality of life following hospitalisation for an acute exacerbation of COPD. Respirology 2005;10:334-340.

12 Choi PP, Day A, Etchells E. Gaps in the care of patients admitted to hospital with an exacerbation of chronic obstructive pulmonary disease. CMAJ 2004;170:1409-1413.

13 Pierson DJ. Clinical practice guidelines for chronic obstructive pulmonary disease: a review and comparison of current resources. Respir Care 2006;51:277-288.

14 NHS Centre for Reviews and Dissemination. Undertaking Systematic Reviews of Research on Effectiveness: CRD's Guidance for Those Carrying Out or Commissioning Reviews. In NHS Centre for Reviews and Dissemination, (ed): York, UK, 2001. [http://www.york.ac.uk/inst/crd/crdreports.htm] 
15 Bratzler DW, Oehlert WH, McAdams LM, Leon J, Jiang H, Piatt D. Management of acute exacerbations of chronic obstructive pulmonary disease in the elderly: physician practices in the community hospital setting. J Okla State Med Assoc 2004;97:227-232.

16 Chang CL, Sullivan GD, Karalus NC, Hancox RJ, McLachlan JD, Mills GD. Audit of acute admissions of chronic obstructive pulmonary disease: inpatient management and outcome. Intern Med J 2007;37:236-241.

17 Cydulka RK, Rowe BH, Clark S, Emerman CL, Camargo CA, Jr. Emergency department management of acute exacerbations of chronic obstructive pulmonary disease in the elderly: the Multicenter Airway Research Collaboration. J Am Geriatr Soc 2003;51:908916.

18 Harvey PA, Murphy MC, Dornom E, Berlowitz DJ, Lim WK, Jackson B. Implementing evidence-based guidelines: inpatient management of chronic obstructive pulmonary disease. Intern Med J 2005;35:151-155.

19 Kelly MG, Elborn JS. Admissions with chronic obstructive pulmonary disease after publication of national guidelines. Ir J Med Sci 2002;171:16-19.

20 Lindenauer PK, Pekow P, Gao S, Crawford AS, Gutierrez B, Benjamin EM. Quality of care for patients hospitalised for acute exacerbations of chronic obstructive pulmonary disease. Ann Intern Med 2006;144:894-903.

21 Roberts CM, Ryland I, Lowe D, Kelly Y, Bucknall CE, Pearson MG. Audit of acute admissions of COPD. standards of care and management in the hospital setting. Eur Respir J 2001;17:343-349.

22 Khan K, Riet G, Popay J, Nixon J, Kleijnen J. Study quality assessment (stage II, phase 5). In Khan K, Riet G, Glanville J, Sowden A, Kleijnen J, (eds): Undertaking Systematic Reviews of Research on Effectiveness: CRD's Guidance for Those Carrying Out or Commissioning Reviews. York, Centre for Reviews and Dissemination, 2001. [http://www.york.ac.uk/inst/crd/crdreports.htm]

23 Deeks J, Khan K, Song F, Popay J, Nixon J, Kleiijnen J. Data synthesis (stage II phase 7); in Khan K, Riet G, Glanville J, Sowden A, Kleijnen J, (eds): Undertaking Systematic Reviews of Research on Effectiveness: CRD's Guidance for Those Carrying Out or Commissioning Reviews. Report Number 4 ( $2^{\text {nd }}$ edn). York, NHS Centre for Reviews and Dissemination, 2001.

[http://www.york.ac.uk/inst/crd/crdreports.htm]

24 Anthonisen NR, Manfreda J, Warren CP, Hershfield ES, Harding GK, Nelson NA. Antibiotic therapy in exacerbations of chronic obstructive pulmonary disease. Ann Intern Med 1987;106:196-204. 
25 The National Collaborating Centre for Chronic Conditions. Diagnosing COPD. National clinical guideline on management of chronic obstructive pulmonary disease in adults in primary and secondary care, 2004. [http://thorax.bmj.com/cgi/reprint/59/suppl_1/i27]

26 Celli BR, Macnee W. Standards for the diagnosis and treatment of patients with COPD: a summary of the ATS/ERS position paper. Eur Respir J 2004;23:932-946.

27 Global Initiative for Chronic Obstructive Lung Disease (GOLD). Global strategy for the diagnosis, management, and prevention of chronic obstructive pulmonary disease, updated 2009. [http://www.goldcopd.org/guidelines-global-strategy-for-diagnosismanagement.html]

28 Siafakas NM, Vermeire P, Pride NB, Paoletti P, Gibson J, Howard P, Yernault JC, Decramer M, Higenbottam T, Postma DS. Optimal assessment and management of chronic obstructive pulmonary disease (COPD). The European Respiratory Society Task Force. Eur Respir J 1995;8:1398-1420.

29 American Thoracic Society. Standards for the diagnosis and care of patients with chronic obstructive pulmonary disease. Am J Respir Crit Care Med 1995;152:S77-121.

30 Pelkonen M. Smoking: relationship to chronic bronchitis, chronic obstructive pulmonary disease and mortality. Curr Opin Pulm Med 2008;14:105-109.

31 Burrows B, Knudson RJ, Cline MG, Lebowitz MD. Quantitative relationships between cigarette smoking and ventilatory function. Am Rev Respir Dis 1977;115:195-205.

32 Barbera JA, Roca J, Ferrer A, Felez MA, Diaz O, Roger N, Rodriguez-Roisin R. Mechanisms of worsening gas exchange during acute exacerbations of chronic obstructive pulmonary disease. Eur Respir J 1997;10:1285-1291.

33 Calverley PM. Oxygen-induced hypercapnia revisited. Lancet 2000;356:1538-1539.

34 Siafkas N, Wedzicha J. Management of acute exacerbation of chronic obstructive pulmonary disease. In Siafkas N, (ed): Management of chronic obstructive pulmonary disease. European Respiratory Monograph. Sheffield, European Respiratory Society Ltd, 2006, vol 11, pp 387-400.

35 Emerman CL, Cydulka RK. Use of peak expiratory flow rate in emergency department evaluation of acute exacerbation of chronic obstructive pulmonary disease. Ann Emerg Med 1996;27:159-163.

36 Emerman CL, Lukens TW, Effron D. Physician estimation of FEV1 in acute exacerbation of COPD. Chest 1994;105:1709-1712.

37 Emerman CL, Effron D, Lukens TW. Spirometric criteria for hospital admission of patients with acute exacerbation of COPD. Chest 1991;99:595-599.

38 Nikander $\mathrm{K}$, Turpeinen $\mathrm{M}$, Wollmer $\mathrm{P}$. The conventional ultrasonic nebulizer proved inefficient in nebulizing a suspension. J Aerosol Med 1999;12:47-53. 
39 Rau JL. Design principles of liquid nebulization devices currently in use. Respir Care 2002;47:1257-1275.

40 Rodriguez-Roisin R. Toward a consensus definition for COPD exacerbations. Chest 2000;117:398S-401S.

41 Mitrouska I, Tzanakis N, Siafkas N: Oxygen therapy in chronic obstructive pulmonary disease. In Siafkas N, (ed): Management of Chronic Obstructive Pulmonary Disease. European Respiratory Monograph. Sheffield, European Respiratory Society Journals Ltd, 2006, vol 11, pp 302-312.

42 Chen AM, Bollmeier SG, Finnegan PM. Long-acting bronchodilator therapy for the treatment of chronic obstructive pulmonary disease. Ann Pharmacother 2008;42:18321842.

43 Rennard S, Calverly P. Bronchodilators in Chronic Obstructive Pulmonary Disease. In Siafkas N, (ed): Management of Chronic Obstructive Pulmonary Disease.European Respiratory Monograph. Sheffield, European Respiratory Society Journals Ltd, 2006, vol 11, pp 266-280.

44 Fink JB, Rubin BK. Problems with inhaler use: a call for improved clinician and patient education. Respir Care 2005;50:1360-1374.

45 Rau JL: Determinants of patient adherence to an aerosol regimen. Respir Care 2005;50:1346-1356

46 Molimard M. How to achieve good compliance and adherence with inhalation therapy. Curr Med Res Opin 2005;21 Suppl 4:S33-S37.

47 Pitta F, Troosters T, Probst VS, Spruit MA, Decramer M, Gosselink R. Physical activity and hospitalisation for exacerbation of COPD. Chest 2006;129:536-544.

48 Puhan MA, Scharplatz M, Troosters T, Steurer J. Respiratory rehabilitation after acute exacerbation of COPD may reduce risk for readmission and mortality -- a systematic review. Respir Res 2005;6:54.

49 Gruffydd-Jones K, Langley-Johnson C, Dyer C, Badlan K, Ward S. What are the needs of patients following discharge from hospital after an acute exacerbation of chronic obstructive pulmonary disease (COPD)? Prim Care Respir J 2007;16:363-368.

50 Dheda K, Crawford A, Hagan G, Roberts CM. Implementation of British Thoracic Society guidelines for acute exacerbation of chronic obstructive pulmonary disease: impact on quality of life. Postgrad Med J 2004;80:169-171.

51 Bott J, Carroll MP, Conway JH, Keilty SE, Ward EM, Brown AM, Paul EA, Elliott MW, Godfrey RC, Wedzicha JA. Randomised controlled trial of nasal ventilation in acute ventilatory failure due to chronic obstructive airways disease. Lancet 1993;341:15551557. 
52 Brochard L, Mancebo J, Wysocki M, Lofaso F, Conti G, Rauss A, Simonneau G, Benito S, Gasparetto A, Lemaire F. Noninvasive ventilation for acute exacerbations of chronic obstructive pulmonary disease. N Engl J Med 1995;333:817-822.

53 European Respiratory Society, European Society of Intensive Care Medicine, Société de Réanimation de Langue Française. International Consensus Conferences in Intensive Care Medicine: noninvasive positive pressure ventilation in acute Respiratory failure. Am J Respir Crit Care Med 2001;163:283-291.

54 Kramer N, Meyer TJ, Meharg J, Cece RD, Hill NS. Randomized, prospective trial of noninvasive positive pressure ventilation in acute respiratory failure. Am J Respir Crit Care Med 1995;151:1799-1806.

55 Plant PK, Owen JL, Elliott MW. Early use of non-invasive ventilation for acute exacerbations of chronic obstructive pulmonary disease on general respiratory wards: a multicentre randomised controlled trial. Lancet 2000;355:1931-1935.

56 Angus RM, Murray S, Kay JW, Thomson NC, Patel KR. Management of chronic airflow obstruction: differences in practice between respiratory and general physicians. Respir Med 1994;88:493-497.

57 Price LC, Lowe D, Hosker HS, Anstey K, Pearson MG, Roberts CM. UK National COPD Audit 2003: Impact of hospital resources and organisation of care on patient outcome following admission for acute COPD exacerbation. Thorax 2006;61:837-842.

58 Roberts CM, Barnes S, Lowe D, Pearson MG. Evidence for a link between mortality in acute COPD and hospital type and resources. Thorax 2003;58:947-949.

59 Ruse CE, Molyneux AW. A study of the management of COPD according to established guidelines and the implications for older patients. Age Ageing 2005;34:299-301.

60 Almagro P, Barreiro B, Ochoa de EA, Quintana S, Rodriguez CM, Heredia JL, Garau J. Risk factors for hospital readmission in patients with chronic obstructive pulmonary disease. Respiration 2006;73:311-317.

61 Bustamante-Fermosel A, De Miguel-Yanes JM, Duffort-Falco M, Munoz J. Mortalityrelated factors after hospitalisation for acute exacerbation of chronic obstructive pulmonary disease: the burden of clinical features. Am J Emerg Med 2007;25:515-522.

62 Groenewegen KH, Schols AM, Wouters EF. Mortality and mortality-related factors after hospitalisation for acute exacerbation of COPD. Chest 2003;124:459-467.

63 Gunen H, Hacievliyagil SS, Kosar F, Mutlu LC, Gulbas G, Pehlivan E, Sahin I, Kizkin O. Factors affecting survival of hospitalised patients with COPD. Eur Respir J 2005;26:234241.

64 Yohannes AM, Baldwin RC, Connolly MJ. Predictors of 1-year mortality in patients discharged from hospital following acute exacerbation of chronic obstructive pulmonary disease. Age Ageing 2005;34:491-496. 
65 Bandolier. Independent evidence-based health care. On Care pathways.; 2003. [http://www.medicine.ox.ac.uk/bandolier/extraforbando/forum2.pdf]

66 Panella M, Marchisio S, Di SF. Reducing clinical variations with clinical pathways: do pathways work? Int J Qual Health Care 2003;15:509-521.

67 Pearson SD, Goulart-Fisher D, Lee TH. Critical pathways as a strategy for improving care: problems and potential. Ann Intern Med 1995;123:941-948.

68 Sermeus W, De BL, Depreitere R, Dewaele K, Vanhaecht K, Vlayen J. An introduction to clinical pathways. In Devriese S, Lambert M, Eyssen M, Van de Sande S, Poelmans J, Van Brabandt H, Sermeus W, Vlayen J, Ramaekers D, (eds): The use of clinical pathways and guidelines to determine physicians' hospital fees prospectively: easier said than done.T. Brussels, Belgian Healthcare Knowledge Centre (KCE). KCE Reports, Volume 18A, 2005. [http:/www.kenniscentrum.fgov.be/nl/publicaties.html]

69 Trowbridge R, Weingarten S. Making health care safer, a critical analysis of patient safety practices.; 2001.

70 Vanhaecht k, Bollman M, Bower K, Gallagher C, Gardine A, Guezo J, Jansen U, Massoud R, Moody K, Sermeus W, Van Zelm R, Whittle C, Yazbeck A, Zander K, Panella M: Prevalence and use of clinal pathways in 23 countries - an internation survey by the European Pathway Association (www.E-P-A-.org). Intl J Care Pathw 2006;10:2834.

71 Vanhaecht K, De Witte K, Sermeus W. The impact of clinical pathways on the organisation of care processes. Leuven, ACCO, 2007.

72 Vanhaecht K, De WK, Depreitere R, Sermeus W. Clinical pathway audit tools: a systematic review. J Nurs Manag 2006;14:529-537. 



\section{Chapter 3:}

Impact of care pathways for in-hospital management of COPD exacerbation: A systematic review

This chapter is published and reproduced with the kind permission of the editor:

Lodewijckx C, Sermeus W, Vanhaecht K, Panella M, Deneckere S, Leigheb F, Decramer M, for the EQCP study group. Impact of care pathways for in-hospital management of COPD exacerbation: a systematic review. Int J Nurs Stud. 2011;48:1445-56. 


\section{Abstract:}

Background. In-hospital management of COPD exacerbation is suboptimal, and outcomes are poor. Care pathways are a possible strategy for optimizing care processes and outcomes.

Objectives. The aim of the literature review was to explore characteristics of existing care pathways for in-hospital management of COPD exacerbations and to address their impact on performance of care processes, clinical outcomes, and team functioning.

Methods. A literature search was conducted for articles published between 1990 and 2010 in the electronic databases of Medline, CINAHL, EMBASE, and Cochrane Library. Main inclusion criteria were (I) patients hospitalised for a COPD exacerbation; (II) implementation and evaluation of a care pathway; (III) report of original research, including experimental and quasi experimental designs, variance analysis, and interviews of professionals and patients about their perception on pathway effectiveness.

Results. Four studies with a quasi-experimental design were included. Three studies used a pre-posttest design; the fourth study was a non-randomized controlled trial comparing and experimental group where patients were treated according to a care pathway with a control group where usual care was provided. The four studied care pathways were multidisciplinary structured care plans, outlining time-specific clinical interventions and responsibilities by discipline. Statistical analyses were rarely performed, and the trials used very divergent indicators to evaluate the impact of the care pathways. The studies described positive effects on blood sampling, daily weight measurement, arterial blood gas measurement, referral to rehabilitation, feelings of anxiety, length of stay, readmission, and in-hospital mortality.

Conclusions. Research on COPD care pathways is very limited. The studies described few positive effects of the care pathways on diagnostic processes and on clinical outcomes. Though due to limited statistical analysis and weak design of the studies, the internal validity of results is limited. Therefore, based on these studies the impact of care pathways on COPD exacerbation is inconclusive. These findings indicate the need for properly designed research like a cluster randomized controlled trial to evaluate the impact of COPD care pathways on performance of care processes, clinical outcomes, and teamwork. 


\section{Introduction}

Patients with chronic obstructive pulmonary disease (COPD) experience frequent exacerbations of symptoms [1-3]. COPD exacerbations are characterized by a change in baseline dyspnea, cough, and/or sputum, that is beyond normal day-to-day variations, is acute in onset, and may warrant additional treatment in a patient with underlying COPD [4]. The annual rate of COPD exacerbations varies from 0.5 to 3.5 exacerbations per patient $[1 ; 3]$.

COPD exacerbations contribute tremendously to the disease burden. They are a leading cause of hospital admission worldwide, with 35\% of COPD patients having at least one admission a year and up to $40 \%$ of admitted patients having two or more readmissions a year $[2 ; 5 ; 6]$. These acute hospital admissions account for the majority (52-84\%) of the overall direct costs related to COPD. In the Confronting COPD Survey conducted in 2003, the annual direct costs per patient were found to be higher in the USA (US\$4119/s3028) and Spain (US\$3196/2349s) and to be lower in the Netherlands (US\$606/s446) and France (US\$522/s384) [7]. COPD exacerbations also have a serious impact on functional status $[1 ; 8])$ and patients' quality of life $[1 ; 9 ; 10]$, and up to $30 \%$ of patients die within one year after hospitalisation, [11;12]. Furthermore, we see high variation in outcomes after hospitalisation for COPD exacerbation; for example, for 30-day mortality (range 5.2-17.2\%) [13], 1-year mortality (23-37\%) [11;12], and 1-year readmission rate (37-67\%) [2;5;6;14].

Several worldwide established evidence-based clinical practice guidelines (CPGs) are available for the assessment and management of patients with COPD [15]; for example, the guidelines of the Global Initiative for Chronic Obstructive Pulmonary Disease (GOLD) [16]; the American Thoracic Society (ATS)-European Respiratory Society Task Force (ERS) [17]; and the National Institute for Clinical Excellence [18]. These guidelines are remarkably consistent, as only two discrepancies with regard to sputum culture and performance of spirometric tests were found. For these two recommendations no research evidence is available, and so both advices are derived from expert committee reports or opinions and/or clinical experience of respected authorities. Sputum culture is useful in identifying bacterial infections and in directing antibiotic therapy. ATS-ERS guidelines recommend sputum cultures for all patients hospitalised with an exacerbation, while GOLD and NICE guidelines only recommend sputum cultures and antibiograms for patients with purulent sputum and in which an infectious exacerbation does not respond to the initial antibiotic treatment [16-18]. With regard to spirometric tests, ATS-ERS and GOLD guidelines do not routinely recommend spirometric tests because these tests are difficult for a sick patient to perform properly and therefore can be inaccurate during acute exacerbations [17]. On the other hand, NICE guidelines recommend measuring spirometry in all patients before discharge [18]. 
Several studies concerning in-hospital management of COPD exacerbation show that guideline adherence is poor and varies highly across organisations [19-21] Lodewijckx et al. (2009) reviewed delivered care in more than 70,000 patients hospitalised with COPD exacerbation. Results showed that non-pharmacological management is extremely suboptimally performed, especially with regard to smoking cessation intervention $(30-42 \%$ of active smokers), education regarding inhaler therapy (20\%), and referral to pulmonary rehabilitation (3-18\%). Also diagnostic and pharmacological management were found to be suboptimal, especially with regard to arterial blood gas measurement (performed in $44-79 \%$ of patients), and administration of corticosteroids (administered in $62-85 \%$ of patients) [21]. Decramer et al. (2003), who questioned management of COPD in 86 pulmonologists in Belgian Hospitals, also found several areas of non-adherence to recommendations of international guidelines, especially with regard to pulmonary rehabilitation, smoking cessation, and non-invasive ventilation [19]. Finally, Hosker et al. (2007) explored hospital care for COPD exacerbation in 233 UK units and found large differences in organisation of care. To illustrate, a considerable number of hospitalised COPD patients had no access to a specialist respiratory ward (35\% of patients had no access), a pulmonary rehabilitation program (36\%), or an early discharge scheme (56\%) [20].

One possible strategy to standardize care processes and to optimize outcomes after hospitalisation for COPD exacerbation is the implementation of a care pathway, also known as clinical pathway or critical pathway [22-26]. Care pathways are complex interventions for the mutual decision making and organisation of predictable care for a well-defined group of patients during a well-defined period, with the aim to enhance the quality of care across the continuum by improving risk-adjusted patient outcomes, promoting patient safety, increasing patient satisfaction, and optimizing the use of resources [27]. In several reviews positive effects of care pathways on clinical outcomes, performance of care processes, costs, teamwork, and patient satisfaction are reported Rotter, 20101044 /id;Sermeus, 2005154 /id;Van Herck, 2004764 /id\}. Most of care pathways were developed for surgery (50\%) such as hip fracture surgery and knee arthroplasty, and for medical conditions (30\%) such as asthma, pneumonia, and stroke. Other domains included were emergency care, psychiatry, palliative care and rehabilitation. However, none of the reviews reported on COPD care pathways. Therefore, two main research questions are explored in this review: (i) What are the characteristics of existing care pathways for in-hospital management of COPD exacerbation with regard to development, implementation, components, and pathway performance; (ii) What is the impact of existing care pathways for in-hospital management of COPD exacerbation on performance of care processes, clinical outcomes, and team functioning? 


\section{Methods}

The methodology used for this review is based on the PRISMA Statement (Preferred Reporting Items for Systematic Reviews and Meta-Analyses of studies that evaluate healthcare interventions) [28;29], and on systematic review methods developed by the NHS Centre for Reviews and Dissemination [30].

\section{Search strategy}

A three-step search strategy was used by author $C L$ to identify relevant peer-reviewed articles between January 1990 and May 2010 (Fig. 1). Firstly, an electronic search was carried out by the first author (CL) in the electronic databases Medline, CINAHL (Cumulative Index for Nursing and Allied Health Literature), EMBASE, and Cochrane Library. The search terms included chronic obstructive pulmonary disease, combined with critical pathway, clinical pathway, and critical path. Since the electronic search resulted in limited amount of records, no search limits were included. Secondly, reference lists of the selected papers were screened for additional literature. Thirdly, Rotter, who conducted a Cochrane review on impact of care pathways on professional practice, patient outcomes, length of stay and hospital costs [31], was consulted to compare our search results with his literature findings regarding impact of COPD care pathways.

Since the literature search in electronic databases revealed a limited amount of papers, we conducted an additional search for unpublished information. Firstly, Google was explored. The search terms COPD, exacerbation, and critical pathway were used. The first ten Google pages were assessed. Secondly, members of the European Respiratory Society (www.ersnet.org) and the European Pathway Association (www.E-P-A.org) were contacted with a request for additional information regarding COPD and care pathways. Finally, the international care pathway conference held in London 2010 was visited to look for recent conducted studies on development and evaluation of COPD care pathways. 


\section{Figure 1. Search strategy}

- Records identified through electronic database searching: $n=140$

Medline: $n=104$

EMBASE: $n=24$

CINAHL: $n=6$

Cochrane Library: $n=6$

- $\quad$ Records identified through searching reference lists and cochrane database Thomas Rotter: $\mathrm{n}=0$

- Unpublished studies identified through search in Google: $n=1$

Records selected for evaluation on title and abstract: $n=119$

Full text articles independently assessed for eligibility by two reviewers (CL \& KV): $n=10$

Records excluded because not meeting the inclusion criteria: $\mathrm{n}=109$

- Not adressing a care pathway: $n=105$

- Another population: $n=3$

- Another setting: $n=1$

Studies included in the systematic review: $\mathrm{n}=5^{*}$

Full text articles excluded because not meeting the inclusion criteria: $n=5$

- Not adressing a care pathway: $n=1$

- Intervention did not meet characteristics of a care pathway: $n=1$

- Another population: $\mathrm{n}=3$

${ }^{*}$ ) 2 papers addressed the same pathway 


\section{Appraisal for inclusion}

Appraisal of the retrieved records occurred in two phases. Records were primary assessed by the first author $(\mathrm{CL})$ on title and abstract, and a first selection was made based on the description of the studied population, the setting, and the general characteristics of the care pathways. Subsequently, the full text of the selected articles was independently screened by two researchers ( $\mathrm{CL}$ and $\mathrm{KV}$ ) to determine whether they met the following inclusion criteria: (I) patients hospitalised with a COPD exacerbation; (II) implementation and evaluation of a care pathway; (III) report of original research, including experimental and quasi experimental designs, variance analysis, and interviews of professionals and patients about their perception of pathway effectiveness. To appraise whether an intervention could be considered a care pathway, we evaluated the intervention on five criteria, based on the care pathway definition of the European Pathway Association (www.E-P-A.be) [27]: (I) aimed for a well-defined group of patients during a well-defined period; (II) an explicit statement of the goals and key elements of care based on evidence, best practice, patients' expectations, and their characteristics; (III) coordination of the roles and sequencing of the activities of the multidisciplinary care team, patients, and their relatives; (VI) documentation, monitoring, and evaluation of variances and outcomes; $(V)$ identification of relevant resources.

\section{Quality appraisal of included studies}

The quality appraisal of the included studies was based on five criteria: (I) appropriateness of methodology (sampling method, data collection, method, and statistics); (II) description of the groups and distribution of prognostic factors; (III) description of the intervention; (IV) generalizability of the results; and (V) limitations of the studies. The description of the intervention was assessed on two main subjects: (I) development and implementation of the care pathway, based on the ingredients for successful pathway implementation, as described by Harkleroad et al. (2000) [32]; and (II) pathway components and performance, based on the care pathway definition of E-P-A [27].

\section{Data extraction}

For each included study, the following data were extracted and reported in overview tables: publication details (date, title, authors); background; objectives; methodology (design, location, inclusion and exclusion, variables and measurement tools, study procedure, analysis); sample size; relevant results; quality assessment of results; conclusion; and implications. For the three studies, the authors were contacted to provide additional information regarding pathway characteristics and results. However, only McManus et al. (2005) could provide us with additional information, solely on the exact time frame of implementation of the pathway and timing of the measurements [33]. 


\section{Data synthesis}

A descriptive data synthesis was conducted, and heterogeneity was assessed. Due to limited data and use of divergent variables within the studies, a meta-analysis of the results could not be performed. For the corresponding variables, differences in means were reported.

Data of the included studies were summarized according to three main areas: study characteristics (study design, aims of the paper, study location, study population, sample size); pathway characteristics (pathway objectives, development, and implementation; pathway components and performance); pathway indicators; baseline variables; process outcomes; clinical outcomes; and team outcomes. Reported p-values were considered statistically significant if $p<0.05$.

In this review, the organisation of care before pathway implementation is referred to as "usual care," and care after the implementation as "pathway care."

\section{Results}

The literature search of the electronic databases revealed a total of 140 publications. After exclusion of the duplicates and quality appraisal, four articles were selected (Fig. 1) [33-36] (Fig. 1). These four articles included three studies on development and impact of COPD exacerbation care pathways [33;34;36] The fourth paper (Marley, 2000) provided additional information on the development and the outcomes of the care pathway investigated in McManus et al. (2005) [33;35]. The screening of the reference lists of the selected articles and the comparison with the search results of Rotter et al. (2010) did not provide additional papers [31].

The additional search for unpublished information revealed one unpublished study on the impact of a care pathway for COPD exacerbation [37]. The study was presented twice on the European Respiratory Congress, firstly in 2006 in Munich by means of a poster presentation, and secondly in 2008 in Berlin during a detailed oral presentation on development, implementation and impact of the COPD care pathway. Since two authors of the study were also involved in this literature review, detailed data on development, implementation, evaluation method, and results were available, and therefore the study of Celis et al. (2006) was also included in this review [37]. Finally, ten interesting blueprints of COPD care pathways were found, however no further information on development, implementation, evaluation and impact of the care pathways was available, and therefore these results were not eligible for inclusion in the literature review. 


\section{Study characteristics}

The aim of the four studies was to evaluate the impact of a care pathway for COPD exacerbation on performance of care processes [33;34;37] and clinical outcomes (Table 1) [33;34;36;37] All studies are monocenter trials, conducted in four university hospitals in the United States [34] Australia [36], Northern Ireland [33] and in Belgium [37]. The studies were performed between 1994 and 2005.

Three studies used a pre-post design, comparing a group where a care pathway was implemented with a historical control group [33;34;36]. Celis et al. (2006) conducted a monocenter non-randomized controlled trial, where an experimental group in which patients were cared for according to a care pathway were compared with a control group in which usual care was provided [37]. Assignment of the patients to each group occurred retrospectively and was based on the assignment of the supervising medical doctor. The medical doctor in the experimental group treated his patients according to a recently updated care pathway, while the medical doctor of the control group was rather reluctant to the use of care pathways and provided usual care. So according to each group, patients were supervised by a specific medical doctor, cared for by specific team, and hospitalised on a specific ward. The wards on which the patients of the experimental and control group were hospitalised were located next to each other. Samples in the four studies varied from 20 to 94 patients per sample.

Data collection occurred prospectively for all four pathway care groups and for two usual care groups in the study of Santamaria et al. (2004) and Celis et al. (2006) [36;37]. In the two other studies, data of usual care patients were gathered retrospectively by reviewing the medical records over the past 12 months [33;34]. With regard to length of stay (LOS), McManus et al. (2005) compared data after pathway implementation (2000-2001) with data over a three-year period before implementation (1996-1998) [33]. The time span between start of pathway implementation and data collection for evaluation was mentioned in three studies, varying from measurements immediately after pathway introduction [33], to five months after the start of the implementation [34]. In Celis et al. (2006) the care pathway was implemented in 2000 and updated in 2003 with regard to evidence based content and coordination of the multidisciplinary team, and the updated pathway was evaluated four months after re-implementation [37].

Celis et al. (2006) and Santamaria et al. (2004) reported baseline patient data in both usual care and pathway care groups [36;37]. McManus et al. (2005) only gathered baseline data in the usual care group [33]; and in the study of Farley (1995) no baseline data were reported [34]. 
Statistical power was calculated only in the study of Santamaria et al. (2004) (power of $80 \%$ ) [36]. Differences between outcomes in usual care and pathway care groups were statistically analyzed in three studies [34;36;37].

Table 1. Study characteristics

\begin{tabular}{|c|c|c|c|c|}
\hline $\begin{array}{l}\text { Author and } \\
\text { year }\end{array}$ & Aim & Design & $\begin{array}{l}\text { Setting and studied } \\
\text { period }\end{array}$ & Sample \\
\hline $\begin{array}{l}\text { Farley (1995) } \\
\text { [34] }\end{array}$ & $\begin{array}{l}\text { To evaluate the impact of } \\
\text { a care pathway for COPD } \\
\text { exacerbation } \\
\text { performance of care } \\
\text { processes and clinical } \\
\text { outcomes }\end{array}$ & $\begin{array}{l}\text { Pre-post } \\
\text { test design }\end{array}$ & $\begin{array}{l}\text { Setting: University } \\
\text { hospital, Vermont, } \\
\text { USA; } 560 \text { beds } \\
\text { Studied period: } 1993- \\
1994\end{array}$ & $\begin{array}{l}\text { Usual care: } \\
\mathrm{n}=30 \\
\text { Pathway care: } \\
\mathrm{n}=20\end{array}$ \\
\hline $\begin{array}{l}\text { Santamaria et } \\
\text { al. (2004) [36] }\end{array}$ & $\begin{array}{l}\text { To evaluate the impact of } \\
\text { a care pathway for COPD } \\
\text { exacerbation on clinical } \\
\text { outcomes }\end{array}$ & $\begin{array}{l}\text { Pre-post } \\
\text { test design }\end{array}$ & 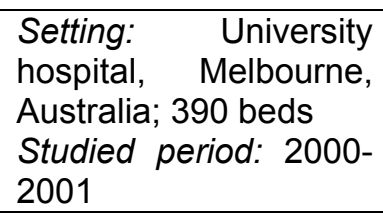 & $\begin{array}{l}\text { Usual care: } \\
\mathrm{n}=90 \\
\text { Pathway care: } \\
\mathrm{n}=88\end{array}$ \\
\hline $\begin{array}{l}\text { McManus et } \\
\text { al. (2005) [33] } \\
\text { Marley (2000) } \\
{[35]}\end{array}$ & $\begin{array}{l}\text { To evaluate the impact of } \\
\text { a care pathway for COPD } \\
\text { exacerbation on } \\
\text { performance of care } \\
\text { processes and clinical } \\
\text { outcomes }\end{array}$ & $\begin{array}{l}\text { Pre-post } \\
\text { test design }\end{array}$ & 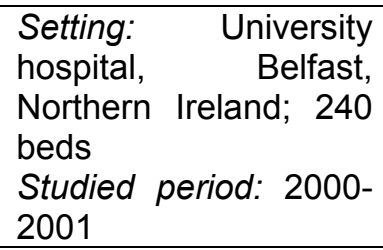 & $\begin{array}{l}\text { Usual care: } \\
\text { not specified } \\
\text { Pathway care: } \\
\mathrm{n}=85\end{array}$ \\
\hline $\begin{array}{l}\text { Celis et al. } \\
(2006) \text { [37] }\end{array}$ & $\begin{array}{l}\text { To evaluate the impact of } \\
\text { a care pathway for COPD } \\
\text { exacerbation on } \\
\text { performance of care } \\
\text { processes and clinical } \\
\text { outcomes }\end{array}$ & $\begin{array}{l}\text { Non } \\
\text { randomized } \\
\text { controlled } \\
\text { trial }\end{array}$ & $\begin{array}{l}\text { Setting: } \quad \begin{array}{l}\text { University } \\
\text { hospital, }\end{array} \text { Leuven, } \\
\text { Belgium, } 1950 \text { beds } \\
\text { Studied period: } 2004\end{array}$ & $\begin{array}{l}\text { Usual care: } \\
n=94 \\
\text { Pathway care: } \\
n=68\end{array}$ \\
\hline
\end{tabular}

\section{Pathway characteristics}

The reported objectives of implementing the care pathway were focused on optimizing processes and clinical outcomes, namely: "delivering evidence-based care" [33;35;37], "improving care" [33;34], "reducing variability" [34], "maximizing the effective use of resources" [36;37], "reducing length of stay and readmission" [33;37], "reducing mortality" [33], and "improving patient understanding and degree of self-control"[36].

In all four studies, a multidisciplinary team was involved in the development and implementation process, and included the following disciplines: medical doctors, nurses physiotherapists, dieticians, occupational therapists, and social workers (Table 2). Two studies, Celis et al. (2006) and Marley (2000) reported the involvement of a clinical nurse specialist COPD, responsible for coordination of the multidisciplinary team, follow-up of patient inclusion and performance of processes, measurement of outcomes, and education of the multidisciplinary team regarding the care pathway [37;38].

As main characteristics of the implementation process, three studies [33;35;37] reported an audit of actual performance of care, reviewing of evidence, piloting of the pathway in 
subsets of patients, and education of hospital staff. None of this was addressed in the study of [36].

Finally, two studies reported involvement of a hospital leader, namely the nurse manager [34], and the head of the respiratory department [37]. The development of the care pathway of McManus et al. (2005) was described in detail in the paper of Marley (2000) [33;35].

With regard to the pathway components and performance, all four pathways included an explicit statement of goals and key elements, and focused on a well-defined group of patients during a well-defined period (Table 2). The four care pathways included key interventions on diagnosis, pharmacological treatment, and non-pharmacological management, according to evidence-based clinical practice guidelines [16-18;39-41]. Furthermore, the four care pathways were multidisciplinary structured care plans, outlining time-specific clinical interventions and responsibilities by discipline [33;34;36;37]. With regard to monitoring and documentation of variances in care and outcomes, Santamaria et al. (2004) mentioned variance tracking and remedial action if a specific intervention was not completed or a timeframe was exceeded [36]. Farley (1995) reported on a semi-automated system of data collection and reporting, in which both compliance to key interventions and documentation was followed up. Finally, none of the studies reported on the identification of appropriate resources [34].

Table 2. Pathway characteristics

\begin{tabular}{|l|c|c|c|c|}
\hline & $\begin{array}{c}\text { Farley } \\
\text { (1995) } \\
{[\text { [34] }}\end{array}$ & $\begin{array}{c}\text { Santamaria } \\
\text { et al. (2004) } \\
{[\text { [36] }}\end{array}$ & $\begin{array}{c}\text { McManus } \\
\text { et al. } \\
\text { (2005) } \\
{[33]}\end{array}$ & $\begin{array}{c}\text { Celis et } \\
\text { al. (2006) } \\
\text { [37] }\end{array}$ \\
\hline $\begin{array}{l}\text { Development and implementation of the } \\
\text { care pathway: } \\
\text { - Multidisciplinary team }\end{array}$ & $\mathrm{X}$ & $\mathrm{X}$ & $\mathrm{X}$ & $\mathrm{X}$ \\
\hline $\begin{array}{l}\text { - Evaluation and analysis of the current care } \\
\text { process }\end{array}$ & $\mathrm{X}$ & & $\mathrm{X}$ & $\mathrm{X}$ \\
\hline $\begin{array}{l}\text { Evaluation of medical evidence and } \\
\text { external practices }\end{array}$ & $\mathrm{X}$ & & $\mathrm{X}$ & $\mathrm{X}$ \\
\hline $\begin{array}{l}\text { - Establishment of preliminary goals and } \\
\text { measurable outcomes }\end{array}$ & $\mathrm{X}$ & $\mathrm{X}$ & $\mathrm{X}$ & $\mathrm{X}$ \\
\hline $\begin{array}{l}\text { Involvement and strong support from } \\
\text { hospital leaders }\end{array}$ & $\mathrm{X}$ & & $\mathrm{X}$ & $\mathrm{X}$ \\
\hline $\begin{array}{l}\text { - Piloting of the care pathway in subsets of } \\
\text { patients }\end{array}$ & $\mathrm{X}$ & & $\mathrm{X}$ & $\mathrm{X}$ \\
\hline - Education of hospital staff & $\mathrm{X}$ & $\mathrm{X}$ & $\mathrm{X}$ & $\mathrm{X}$ \\
\hline $\begin{array}{l}\text { Care pathway components and } \\
\text { performance: }\end{array}$ & Aimed for a well-defined group of patients & $\mathrm{X}$ & & \\
\hline
\end{tabular}




\begin{tabular}{|l|c|c|c|c|}
\hline - Aimed for a well-defined period & X & X & X & X \\
\hline Multidisciplinary team & X & X & X & X \\
\hline $\begin{array}{l}\text { An explicit statement of the goals and key } \\
\text { elements of care }\end{array}$ & $\mathrm{X}$ & $\mathrm{X}$ & $\mathrm{X}$ & $\mathrm{X}$ \\
\hline $\begin{array}{l}\text { The care pathway outlines time specific } \\
\text { clinical interventions on day to day basis } \\
\text { and nominates responsibilities by discipline }\end{array}$ & $\mathrm{X}$ & $\mathrm{X}$ & $\mathrm{X}$ & $\mathrm{X}$ \\
\hline $\begin{array}{l}\text { Documentation, monitoring, and evaluation } \\
\text { of variances and outcomes }\end{array}$ & $\mathrm{X}$ & $\mathrm{X}$ & & \\
\hline - Identification of the appropriate resources & & & & \\
\hline
\end{tabular}

\section{Pathway indicators}

The indicators used to evaluate the care pathways included process, outcome, and team indicators (Table 3). Process indicators were followed up in the studies of Farley (1995) ( $\mathrm{n}=$ 11 process indicators), McManus et al. (2005) ( $n=1$ process indicator) and Celis et al. (2006) ( $n=4$ process indicators) [33;34;37]. Six process indicators focused on diagnostics, three on pharmacological treatment, and five on non-pharmacological interventions.

Most commonly used outcome indicators included LOS, readmission, and in-hospital death [33-37]. Team indicators were only explored in McManus et al. (2005), including effect of the care pathway on multidisciplinary communication, staff satisfaction, and ongoing education [33].

Table 3. Pathway indicators

\begin{tabular}{|c|c|c|c|c|}
\hline & $\begin{array}{l}\text { Farley, } \\
1995[34]\end{array}$ & $\begin{array}{c}\text { Santamaria } \\
\text { et al. (2004) } \\
{[36]}\end{array}$ & $\begin{array}{c}\text { McManus } \\
\text { et al. (2005) } \\
{[33]} \\
\end{array}$ & $\begin{array}{l}\text { Celis et al. } \\
(2006) \text { [37] }\end{array}$ \\
\hline $\begin{array}{l}\text { Process indicators: } \\
\text { - Arterial blood gas measurement }\end{array}$ & $\mathrm{X}$ & & & $\mathrm{X}$ \\
\hline - Performance of chest radiography & $X$ & & & $X$ \\
\hline - Lung function tests & & & & $\mathrm{X}$ \\
\hline $\begin{array}{l}\text { - Daily weight measurement when } \\
\text { ordered }\end{array}$ & $X$ & & & \\
\hline - Blood sampling & $X$ & & & \\
\hline - Oxygen saturation measurement & $\mathrm{X}$ & & & \\
\hline - Prescription of steroids & $X$ & & & \\
\hline - Prescription of antibiotics & $X$ & & & \\
\hline - Use of air driven nebulizer & & & & \\
\hline - Social work consult & $X$ & & & \\
\hline $\begin{array}{l}\text { - Physiotherapist consult within } 24 \\
\text { hours of admission }\end{array}$ & $\mathrm{X}$ & & & \\
\hline - Nutrition consult within 48 hours & $\mathrm{X}$ & & & \\
\hline $\begin{array}{l}\text { Discharge plan documented within } \\
48 \text { hours of admission }\end{array}$ & $X$ & & & \\
\hline
\end{tabular}




\begin{tabular}{|c|c|c|c|c|}
\hline - Referal to rehabilitation & & & & $\mathrm{X}$ \\
\hline $\begin{array}{l}\text { Outcome indicators: } \\
\text { - Length of stay }\end{array}$ & $x$ & $X$ & $x$ & $x$ \\
\hline - Readmission & $x$ & $\mathrm{X}$ & $X$ & $X$ \\
\hline - In-hospital mortality & & $X$ & $\mathrm{X}$ & \\
\hline - Charges per case & $X$ & & & \\
\hline - Oxygen saturation & & $x$ & & \\
\hline - Dyspnoea score & & $\mathrm{X}$ & & \\
\hline - Peak flow & & $x$ & & \\
\hline - Anxiety score & & $x$ & & \\
\hline - Complications rate & & $X$ & & \\
\hline $\begin{array}{l}\text { Team indicators: } \\
\text { - Multidisciplinary communication and } \\
\text { care planning }\end{array}$ & & & $x$ & \\
\hline - Staff satisfaction & & & $\mathrm{X}$ & \\
\hline $\begin{array}{l}\text { Communication with the primary } \\
\text { care team }\end{array}$ & & & $X$ & \\
\hline $\begin{array}{l}\text { Facilitation of staff training and } \\
\text { education }\end{array}$ & & & X & \\
\hline
\end{tabular}

\section{Baseline variables}

Comparison of the baseline data between the usual care and pathway care group was performed in [36;37]. Baseline characteristics in both groups were highly comparable, with the following data being measured: age, gender [36;37], BMI, COPD severity [37], saturation, pulse rate, respiratory rate, peak flow, dyspnea, anxiety, number of comorbidities, and presence of cough [36].

\section{Process indicators}

With regard to diagnostic processes, a significant increase of $47 \%$ was found for "blood sampling" (23\% vs. 70\%; $p=0.01)$ [34] (Table 4). Farley (1995) also reported a large improvement of $28 \%$ for "daily weight measurement when ordered" ( $47 \%$ vs. $75 \%$; $p=0.05)$ and "performance of arterial blood gases" (63\% vs. $90 \%$; $p=0.05)$, but results were not found to be significant [34]. Finally, Celis et al. (2006) assessed the number of diagnostic tests performed per patient [37]. They reported a smaller number of chest X-rays performed per patient (4.6 vs. $3.3 ; p=0.05$ ) and a significant smaller number of arterial blood gas measurements per patient $(9.2$ vs. $3.5 ; p<0.05)$ in the care pathway patients. On the other hand, a considerable higher number of lung function tests per patient was performed in the pathway group (3.1 vs. $7.4 ; p=0.05)$. Also, 22 of 94 patients in the control group $(23.4 \%)$ did not perform any lung function test, while all patients in the experimental group at least performed two lung function tests during hospitalisation [37]. 
With regard to pharmacological management, A 17-fold increase in the use of air-driven nebulizers was reported in the study of McManus et al. (2005), yet no detailed data on the shift of oxygen driven to air-driven nebulizers were reported [33].

Finally, one significant improvement for non pharmacological management was found, namely an increase of more than $25 \%$ with regard to inclusion of patients in a rehabilitation program $(8.8 \%$ vs. $25.3 \%$; $p<0.05)$ [37].

McManus et al. (2005) and Marley (2000) also mentioned overall improvements in the performance of care processes in terms of "improved clinical audit reporting and interpretation," "care exceeding existing quality standards," "more structured approached to care," "reduced undesirable practice variation," "identification of shortfalls in current practice," and "development of a drugs/oxygen protocol." However, no numeric data on these findings were reported [33;35].

\section{Clinical outcomes}

With regard to clinical outcomes, significant improvements were found for LOS and interval before readmission [37], and for feelings of anxiety (Table 4) [36].

Mean LOS was measured in all four studies (Table 4). In the three pre-post test studies, LOS before implementation differed considerably in the three studies, ranging from 6.5 and 7.6 days [34;36], to 9.4 days [33]. LOS after pathway implementation was highly comparable in the three studies, with a reduction in LOS of less than a day in Santamaria et al. (2004) (7.60 vs. 6.71 days) to 4 days in McManus et al. (2005) (9.4 vs. 5.5 days) [33;36]. In Farley (1995), LOS increased by half a day (6.5-7.1 days) [34]. However, LOS results were not statistically significant [36] or not statistically tested [33;34]. Moreover, in McManus et al. (2005) LOS in usual care was calculated over the three-year period before implementation of the pathway [33]. In comparison with the three pre-posttest studies, Celis et al. (2006) reported a considerable higher mean LOS in both pathway care group and usual care group (10.2 vs. 13.2), however the pathway group had a significant shorter LOS of three days ( $p=$ 0.03) [37].

Thirty-day readmission was measured in Santamaria et al. (2004) and McManus et al. (2005), and showed a considerably difference between both studies before implementation (19\% vs. $12 \%$, respectively) (Table 4) [33;36]. After pathway implementation 30-day readmission decreased by $4 \%$ in both studies, varying from $15 \%$ [36] to $8 \%$ [33], although results were not statistically confirmed. Celis et al. (2006) measured readmission rate within one year and found a considerable higher readmission rate in the care pathway group compared to the control group ( $45.6 \%$ vs. $35.1 \%$; $p>0.05)$, however results were not statistically significant. On the other hand, interval before readmission was significantly larger in the pathway group compared to the control group (160.8 vs. 94.4 days; $p=0.029$ ) [37]. 
Anxiety was scored on a $100 \mathrm{~mm}$ Visual Analogue Scale (VAS), with "0" meaning "feeling calm" and "100" meaning "feeling panic." A significant improvement of 4.5 units was found after pathway implementation [36].

Two studies addressed in-hospital mortality (Table 4) [33;36]. Santamaria et al. (2004) reported a $1 \%$ decrease in in-hospital deaths in the care pathway group (10\% vs. 9\%), however this result was not statistically analyzed [36]. McManus et al. (2005) presented a decrease of $57 \%$, though no data on the number of in-hospital deaths were provided [33].

Finally, the standard care group in Santamaria et al. (2004) had numerically more complications than the pathway group (19 vs. 13), however this difference was not found to be significant (Table 4) [36]. Other outcomes of oxygen saturation and dyspnea-score assessed in Santamaria et al. (2004) showed no relevant differences after pathway implementation [36].

\section{Team outcomes}

Team outcomes were only reported by McManus et al. (2005) [33]. Improvement in team functioning was reported in terms of "improved multidisciplinary communication and care planning," "improved staff satisfaction," "facilitation of staff training and education," and "improved communication with the primary care team," though no details on measurements of these team outcomes were mentioned [33;35].

Table 4. Outcomes in usual care group versus pathway care group

\begin{tabular}{|c|c|c|c|}
\hline Farley (1995) [34]: & $\begin{array}{c}\text { Usual care } \\
\qquad n=30\end{array}$ & $\begin{array}{l}\text { Pathway } \\
\text { care } \\
n=20\end{array}$ & $p$ \\
\hline \multirow{3}{*}{$\begin{array}{l}\text { - Mean length of stay, days } \\
\text { - Number of patients in which LOS > } 6 \text { days, } n(\%) \\
\text { - Number of patients in which: }\end{array}$} & 6.5 & 7.1 & l \\
\hline & $14(46.6)$ & $7(35.0)$ & l \\
\hline & & & \\
\hline ○ Daily weight was measured when ordered, $\mathrm{n}(\%)$ & $14(46.6)$ & $15(75.0)$ & 0.05 \\
\hline$\circ \quad$ Chest radiography was performed, $\mathrm{n}(\%)$ & $24(80.0)$ & $17(85.0)$ & l \\
\hline $\begin{array}{l}\text { Arterial blood gases within first } 24 \text { hours were } \\
\text { measured, } \mathrm{n}(\%)\end{array}$ & $19(63.3)$ & $18(90.0)$ & 0.05 \\
\hline ○ Albumin/nutrition profile was obtained, n (\%) & $7(23.3)$ & $14(70.0)$ & 0.01 \\
\hline - Standing orders were used, $\mathrm{n}(\%)$ & 1 & $15(75.0)$ & l \\
\hline $\begin{array}{l}\text { Oxygen saturations were obtained every } 4 \\
\text { hours, } \mathrm{n}(\%)\end{array}$ & I & $12(60.0)$ & I \\
\hline Santamaria et al. (2004) [36]: & $\begin{array}{l}\text { Usual care } \\
\qquad n=90\end{array}$ & $\begin{array}{c}\text { Pathway } \\
\text { care } \\
\text { n=88 }\end{array}$ & $\mathbf{p}$ \\
\hline - Mean length of stay, days (SD) & $7.6(7.0)$ & $6.7(4.3)$ & 0.15 \\
\hline - In-hospital mortality, n (\%) & $9(10.0)$ & $8(9.1)$ & l \\
\hline - Readmission within 30 days, $\mathrm{n}(\%)$ & $19(21.1)$ & $15(17)$ & 0.24 \\
\hline
\end{tabular}




\begin{tabular}{|c|c|c|c|}
\hline $\begin{array}{l}\text { - Number of patients who developed complications, } \mathrm{n} \\
(\%)\end{array}$ & $11(12.2)$ & $4(4.5)$ & I \\
\hline $\begin{array}{l}\text { - Mean dyspnoea score on } 100 \mathrm{~mm} \text { Visual Analogue } \\
\text { Scale (SD) }{ }^{\mathrm{a}}\end{array}$ & $2.2(1.7)$ & $1.8(1.0)$ & 0.11 \\
\hline $\begin{array}{l}\text { - Mean anxiety score, score on } 100 \mathrm{~mm} \text { Visual Analog } \\
\text { Scale (SD) }\end{array}$ & $14.2(1.4)$ & $9.7(0.8)$ & 0.02 \\
\hline - Mean oxygen saturation, \% (SD) & $94.2(22.7)$ & $94.3(19.8)$ & 0.65 \\
\hline McManus et al. (2005) [33]: & $\begin{array}{l}\text { Usual care } \\
\qquad \text { n=not } \\
\text { specified }\end{array}$ & $\begin{array}{c}\text { Pathway } \\
\text { care } \\
\text { n=85 }\end{array}$ & p \\
\hline - Mean length of stay, days & $9.4^{c}$ & 5.5 & I \\
\hline - In-hospital mortality & l & $\begin{array}{l}\text { Reduction of } \\
57 \%\end{array}$ & I \\
\hline - Readmission within 30 days, $\mathrm{n}(\%)$ & $n(12.0)^{d}$ & $7(8.2)$ & I \\
\hline - Use of air driven nebulizers & l & $\begin{array}{l}17 \text { fold } \\
\text { increase }\end{array}$ & l \\
\hline Celis et al. (2006) [37] & $\begin{array}{l}\text { Usual care } \\
\qquad n=94\end{array}$ & $\begin{array}{c}\text { Pathway } \\
\text { care } \\
n=68\end{array}$ & \\
\hline - Mean Length of stay, days (SD) & $13.2(12.7)$ & $10.2(3.9)$ & 0.04 \\
\hline - Readmission rate within one year, $\mathrm{n}(\%)$ & $33(35.1)$ & $31(45.6)$ & $>0.05$ \\
\hline - Interval before readmission, days (SD) & $94.4(95.2)$ & $160.8(117.8)$ & 0.03 \\
\hline - Referred to a rehabilitation program, $\mathrm{n}(\%)$ & $8(8.5)$ & $17(25.0)$ & $<0.05$ \\
\hline $\begin{array}{l}\text { - Mean number of times processes were performed } \\
\text { per patient: }\end{array}$ & & & \\
\hline$\circ$ Chest X-ray was performed, $n$ & 4.6 & 2.3 & 0.05 \\
\hline - Arterial blood gases were performed, $\mathrm{n}$ & 9.2 & 3.5 & $<0.05$ \\
\hline - Lung function tests were performed, $\mathrm{n}$ & 3.1 & 7.4 & 0.05 \\
\hline
\end{tabular}

${ }^{a}$ Scoring Visual Analogue Scale: $0=$ no shortness of breath; $100=$ worst shortness of breath ever experienced

${ }^{\mathrm{b}} 0=$ feel calm; $100=$ feeling panic; ${ }^{\mathrm{c}}$ Calculated over a three-year period $1996-1998 ;{ }^{\mathrm{d}} \mathrm{n}=\mathrm{not}$ specified

\section{Discussion}

COPD exacerbation is worldwide a leading cause of hospital admission. However, care for patients hospitalised with COPD exacerbation is suboptimal according to recommendations of international guidelines, and outcomes during and after hospitalisation are poor and vary highly. These findings indicate the critical need for standardization and optimalisation of the care processes for patients hospitalised with COPD exacerbation. Care pathways are known to improve care processes and to optimize outcomes. A literature search on care pathways for in-hospital management of COPD exacerbation revealed only four studies, of which three studies with a pre-post design, and one randomized controlled trial. The four studied care pathways were multidisciplinary-structured care plans, outlining time-specific clinical 
interventions and responsibilities by discipline. The studies showed positive effects on blood sampling, daily weight measurement, arterial blood gas measurement, feelings of anxiety, LOS, readmission, and in-hospital mortality.

\section{Methodological quality of the studies}

The methodological quality of the included studies was weak for several reasons. Firstly, the design of the studies needs to be discussed. Three of the four studies used a pre-post design, comparing an experimental group in which a care pathway was implemented with a historical control group. This design leads to limited internal validity of the results due to the following reasons. (I) History: Outcomes could have been caused by an historical event, and were possibly not related to the intervention; for instance, financial incentives to reduce LOS. (II) Maturation or effect of time: Because of organisational and management evolutions, the same outcomes could have been achieved without implementing a pathway. (III) Testing or effect of measuring: Performing the pretest could have made the multidisciplinary COPD care team more aware of bottlenecks in the care for COPD patients, and consequently could have made them change their care irrespective of the implementation of a pathway. (IV) The Hawthorne-effect or effect of attention due to the project: Performance of care processes could have been improved because of the attention of the project, not because of the implementation of the care pathway itself [42-44]. In the fourth study of Celis et al. (2006), patients out of a single organisation were assigned to an experimental group where care was provided according to a care pathway, and a control group where usual care was delivered [37]. Assignment did not occur randomly, but was based on assignment to a specific medical doctor. The lack of randomization could lead to incomparable groups which could compromise internal validity of results, however in this study baseline characteristics of age, gender, COPD severity and BMI were highly comparable. The design of Celis et al. (2006) [37] also carries an important risk for contamination of the control group, because the multidisciplinary team and the patients in the pathway group might affect the team and the patients in the control group by sharing information and experiences about the treatment [45]. Finally, the four included trials, all conducted in a single organisation, include the risk for selection bias. When evaluating a complex intervention in a single organisation, with its specific context like the coordination of the care process, the multidisciplinary team and the specific types of patients, it is difficult or even impossible to ascertain whether the results are dependent of the context under study or whether they are generalizable to a wider context [46;47] To overcome these issues and so to appropriately evaluate complex interventions like care pathways, adequately designed research is needed. As described by the medical research council, the golden standard to evaluate complex interventions is a cluster randomized controlled trial (cRCT) [48]. In cRCTs clusters, instead of patients, are 
randomized into an intervention and a control group, and outcomes are measured in the patients within those clusters [45].

A second methodologically issue has to do with power calculation and sample size. Power calculation was only performed in the study of Santamaria et al. (2004) [36], and sample sizes in the four studies were small, especially in Farley (1995) (Table 1) [34]. Also, Farley (1995) and Celis et al. (2006) reported considerably unequal sample sizes in experimental and control groups (Table 1), and therefore power of the statistical t-tests is limited [34;37]. Finally, statistical analyses were limited calculated in three of the four studies $[34 ; 36]$.

Thirdly, comparison of baseline patient characteristics was only performed in the study of Celis et al. (2006) and Santamaria et al. (2004) [36;37] This implies that improvement in outcomes in the studies of Farley (1995) and McManus et al. (2005) are possibly the result of better patient characteristics in the post-test instead of being related to the pathway implementation [33;34]

Finally time span between start of pathway implementation and evaluation varied from measurements immediately after pathway introduction [33] to five months after the start of the implementation [34]. The first months after implementation certain key elements of care and organisational aspects may need refinement or adjustment. To obtain stable and valid results, it is strongly recommended to start a first thoroughly evaluation no earlier than two or three months after pathway implementation [32].

\section{Pathway characteristics}

The care pathways of Celis et al. (2006) [37], Farley (1995) [34] and McManus et al. (2005) [33] were well described with regard to objectives, development, implementation, and characteristics (Table 2), and correspond very well with the care pathway criteria addressed in the definition of E-P-A [27] and in the review of Harkleroad et al. (2000) [32]. In contrast, the pathway of Santamaria et al. (2004) was incompletely described in several aspects (Table 2) [36], which makes it difficult to appraise the quality of the intervention, especially with regard to the evidence-based level of the pathway intervention, focus on bottlenecks in actual care, feasibility of the pathway in clinical practice, and knowledge level of the multidisciplinary care team. Importantly, education of the team needs to include information on the pathway content and process, but also justification on the implementation of the care pathway, in order to encourage team motivation and adherence to the key interventions of the care pathway [32]. Also, only two studies reported involvement of a hospital leader [34;37], and none of the studies addressed identification and utilization of resources like staffing or electronic support, even though both support of hospital leaders and availability of 
appropriate resources are important conditions for successful implementation and performance of the pathway [32].

\section{Pathway indicators}

The four studies mostly addressed outcome indicators (Table 3). Farley (1995) indeed also reported on ten process indicators, but results for only five indicators were very limitedly displayed and discussed (Table 4) [34]. Finally, McManus et al. (2005) also mentioned improved team outcomes but did not detail any results [33;35].

Care pathways are defined by the European Pathway Association as complex interventions comprising active components, such as evidence-based key interventions, feedback on actual performance, and development and implementation strategies [27;49]. Furthermore, context of the organisation (e.g., type of hospital, availability of resources) and the involved multidisciplinary team will influence the effect of the care pathway [50-53]. Therefore, to fully understand the achieved outcomes after implementation of a care pathway, also knowledge on performance of care processes, organisational context, and team working is essential [50]. Consequently, next to outcome indicators, also process indicators, team indicators and variables on organisational context should be measured in research on the impact of complex interventions like care pathways [50;51].

\section{Pathway outcomes}

Although the studies mentioned the follow-up of a considerable number of indicators (Table 3 ), outcomes of these indicators were scarcely reported (Table 4). Also, because of the use of divergent indicators in the four studies, meta-analysis of the results was not possible.

With regard to process outcomes, a clinical important improvement of $30-47 \%$ in the care pathway group was reported for daily weight measurement, arterial blood gas measurement, blood sampling and inclusion in a rehabilitation program, although only the two last results were reported significant (Table 4) However, performance of this care processes was still suboptimal, especially with regard to referral to rehabilitation. Interestingly, Celis et al. (2006) focused on the number of times a particular process was performed per patient [37]. The results showed a lower number of ABG measurements and a lower number of chest X-ray performances per patient in the care pathway group, suggesting a reduction of unnecessary diagnostic tests in patients by implementing a care pathway. On the other hand, in the care pathway group more lung function tests were performed per patient in comparison with the control group (Table 4). Whether this finding indicates a positive or negative result is disputable, since existing guidelines are divergent regarding benefit of performing spirometry tests in acute exacerbated patients [16-18]. However, it is 
certainly questionable if it is necessary to perform so many lung function tests per patient (mean number of seven tests per patient) during hospitalisation for exacerbation.

Concerning clinical outcomes, 30-day readmission rate, interval before readmission, inhospital death, and mean LOS improved after implementation of the pathway (Table 4) [33;36;37], however only one result, interval before readmission, was found significant. In Farley (1995), LOS increased by almost a day after implementation of the care pathway; however, this result was not statistically confirmed [34]. Only feelings of anxiety were found to significantly improve after pathway implementation, but a very little and so not clinical relevant change on the $100 \mathrm{~mm}$ VAS was found [36]. Moreover, the study did not mention on what hospitalisation day and at what time anxiety was measured in both groups. Results of anxiety analogue scales fluctuate over time [54], so it is unclear if this is a valid comparison of anxiety scores between the pre- and posttest group.

Finally, team outcomes reported by McManus et al. (2005) [33] seem reasonable, as one of the characteristics of a care pathway is "coordination of the roles and sequencing of the activities of the multidisciplinary care team, patients and their relatives" [27]. However, due to lack of measuring details these outcomes cannot be verified.

Overall, the weak methodology and limited reporting of pathway outcomes put a serious threat on the internal validity of the results. In addition, three of the four studies were performed 10 years ago or even earlier [33;34;36], which makes the results less applicable for current COPD health care.

\section{Additional literature search}

The findings of the additional search for unpublished information, including an interesting unpublished study [37] and several blueprints of COPD care pathways, indicate that probably hundreds of care pathways for COPD have been developed, but like many quality projects, they not have been evaluated and published. To further understand why and when pathways work, publications on project reports and evaluations of COPD pathways must be supported.

\section{Conclusions}

COPD patients hospitalised with exacerbation are a high volume, a high cost and high risk population, and actual care for these patients has shown to be very suboptimal. Therefore this literature review on the impact of care pathways on COPD processes and outcomes is relevant for all health care professionals caring for COPD patients. Next to that, a comprehensive discussion on evaluation of complex interventions like care pathways is included in this review. 
The four studies included in the review described few positive effects of the care pathways on diagnostic processes and on clinical outcomes, though due to limited statistical analysis and weak design of the studies, the internal validity of the results is limited. Furthermore, limited data and use of different indicators in the four studies make metaanalysis of results impossible. Therefore, based on current research, accurate conclusions on the impact of COPD exacerbation care pathways cannot

be drawn. These findings indicate the need for appropriately designed research like a cluster randomized controlled trial to study the impact of COPD exacerbation pathways.

In 2009 the European Pathway Association launched the European Quality of Care Pathways study (EQCP study) [55;56]. The EQCP study is an international clustered randomized controlled trial, with the aim to measure the impact of care pathways on compliance to care processes and performance of clinical outcomes in patients hospitalised with a COPD exacerbation. An evidence-based set of process and outcome indicators will be followed up in organisations in which a pathway was implemented compared to organisations in which usual care is provided. Additionally, multidisciplinary teamwork and organisational context will be assessed using a set of evidence based team indicators and organisational variables $[27 ; 55 ; 57]$.

\section{Acknowledgements}

We acknowledge the supporting of the Clinical Research Fund of UZ Leuven, Belgium. We also acknowledge Pfizer Belgium, Pfizer Italy, Pfizer Ireland, and Pfizer Portugal, who supported this research by providing an unrestricted educational grant. The autonomy of EP-A and all involved academic institutions with regard to scientific independence and intellectual property on methodology is guaranteed. 


\section{References}

1 Chenna PR, Mannino DM. Outcomes of severe COPD exacerbations requiring hospitalisation. Semin Respir Crit Care Med 2010;31:286-294.

2 Izquierdo JL, Barcina C, Jimenez J, Munoz M, Leal M. Study of the burden on patients with chronic obstructive pulmonary disease. Int J Clin Pract 2009;63:87-97.

3 Seemungal TA, Hurst JR, Wedzicha JA. Exacerbation rate, health status and mortality in COPD--a review of potential interventions. Int J Chron Obstruct Pulmon Dis 2009;4:203223.

4 Burge S, Wedzicha JA. COPD exacerbations: definitions and classifications. Eur Respir J Suppl 2003;41:46s-53s.

5 Cao Z, Ong KC, Eng P, Tan WC, Ng TP. Frequent hospital readmissions for acute exacerbation of COPD and their associated factors. Respirology 2006;11:188-195.

6 Garcia-Aymerich J, Farrero E, Felez MA, Izquierdo J, Marrades RM, Anto JM. Risk factors of readmission to hospital for a COPD exacerbation: a prospective study. Thorax 2003;58:100-105.

7 Wouters EF. Economic analysis of the Confronting COPD survey: an overview of results. Respir Med 2003;97 Suppl C:S3-14.

8 Bourbeau J. Activities of life: the COPD patient. COPD 2009;6:192-200.

9 Seemungal TA, Donaldson GC, Paul EA, Bestall JC, Jeffries DJ, Wedzicha JA. Effect of exacerbation on quality of life in patients with chronic obstructive pulmonary disease. Am J Respir Crit Care Med 1998;157:1418-1422.

10 Wang Q, Bourbeau J. Outcomes and health-related quality of life following hospitalisation for an acute exacerbation of COPD. Respirology 2005;10:334-340.

11 Groenewegen $\mathrm{KH}$, Schols AM, Wouters EF. Mortality and mortality-related factors after hospitalisation for acute exacerbation of COPD. Chest 2003;124:459-467.

12 Yohannes AM, Baldwin RC, Connolly MJ. Predictors of 1-year mortality in patients discharged from hospital following acute exacerbation of chronic obstructive pulmonary disease. Age Ageing 2005;34:491-496.

13 Agabiti N, Belleudi V, Davoli M, Forastiere F, Faustini A, Pistelli R, Fusco D, Perucci CA. Profiling hospital performance to monitor the quality of care: the case of COPD. Eur Respir J 2010;35:1031-1038.

14 Gudmundsson G, Gislason T, Janson C, Lindberg E, Hallin R, Ulrik CS, Brondum E, Nieminen MM, Aine T, Bakke P. Risk factors for rehospitalisation in COPD: role of health status, anxiety and depression. Eur Respir J 2005;26:414-419.

15 Pierson DJ. Clinical practice guidelines for chronic obstructive pulmonary disease: a review and comparison of current resources. Respir Care 2006;51:277-288. 
16 Global Initiative for Chronic Obstructive Lung Disease (GOLD). Global strategy for the diagnosis, management, and prevention of chronic obstructive pulmonary disease, updated 2009. [http://www.goldcopd.org/guidelines-global-strategy-for-diagnosismanagement.html]

17 Celli BR, Macnee W. Standards for the diagnosis and treatment of patients with COPD a summary of the ATS/ERS position paper. Eur Respir J 2004;23:932-946.

18 National Institute for Clinical Excellence (NICE). Chronic obstructive pulmonary disease: national clinical guideline for management of chronic obstructive pulmonary disease in adults in primary and secondary care. Thorax 2004;59:1-53.

19 Decramer M, Bartsch P, Pauwels R, Yernault JC. Management of COPD according to guidelines. A national survey among Belgian physicians. Monaldi Arch Chest Dis 2003;59:62-80.

20 Hosker H, Anstey K, Lowe D, Pearson M, Roberts CM. Variability in the organisation and management of hospital care for COPD exacerbations in the UK. Respir Med 2007;101:754-761.

21 Lodewijckx C, Sermeus W, Vanhaecht K, Panella M, Deneckere S, Leigheb F, Decramer $M$. Inhospital management of COPD exacerbations: a systematic review of the literature with regard to adherence to international guidelines. Journal of Evaluation in Clinical Practice 2009;15:1101-1110.

22 Campbell H, Hotchkiss R, Bradshaw N, Porteous M Integrated care pathways. BMJ 1998;316:133-137.

23 Panella M, Marchisio S, Di SF. Reducing clinical variations with clinical pathways: do pathways work? Int J Qual Health Care 2003;15:509-521.

24 Pearson SD, Goulart-Fisher D, Lee TH. Critical pathways as a strategy for improving care: problems and potential. Ann Intern Med 1995;123:941-948.

25 Vanhaecht K, De Witte K, Panella M, Sermeus W. Do pathways lead to better organised care processes? Journal of Evaluation in Clinical Practice 2009;15:782-788.

26 Zander K, Bower K. Implementing strategies for managing care. Boston, 2000.

27 Vanhaecht K, De Witte K, Sermeus W. The impact of clinical pathways on the organisation of care processes. Leuven, ACCO, 2007.

28 Moher D, Liberati A, Tetzlaff J, Altman DG. Preferred reporting items for systematic reviews and meta-analyses: the PRISMA statement. BMJ 2009;339:b2535.

29 Liberati A, Altman DG, Tetzlaff J, Mulrow C, Gotzsche PC, loannidis JP, Clarke M, Devereaux PJ, Kleijnen J, Moher D. The PRISMA statement for reporting systematic reviews and meta-analyses of studies that evaluate healthcare interventions: explanation and elaboration. BMJ 2009;339:b2700. 
30 NHS Centre for Reviews and Dissemination: Undertaking Systematic Reviews of Research on Effectiveness: CRD's Guidance for Those Carrying Out or Commissioning Reviews. In NHS Centre for Reviews and Dissemination, (ed): York, UK, 2001.

[http://www.york.ac.uk/inst/crd/crdreports.htm]

31 Rotter T, Kinsman L, James E, Machotta A, Gothe H, Willis J, Snow P, Kugler J. Clinical pathways: effects on professional practice, patient outcomes, length of stay and hospital costs. Cochrane Database Syst Rev 2010;3:CD006632.

32 Harkleroad A, Schirf D, Volpe J, Holm MB. Critical pathway development: an integrative literature review. Am J Occup Ther 2000;54:148-154.

33 McManus TE, Marley A, Kidney JC. The Mater Hospital multiprofessional care pathway for acute exacerbations of chronic obstructive pulmonary disease. Intl $\mathrm{J}$ Care Pathw 2005;9:32-36.

34 Farley K. The COPD critical pathway: a case study in progress. Qual Manag Health Care 1995;3:43-54.

35 Marley AM. A care pathway for COPD. Prof Nurse 2000;16:821-823.

36 Santamaria N, Conners A, Osteraas J, Ham J, Boodram B. A prospective cohort study of the effectiveness of clinical pathways for the in-patient management of acute exacerbation of chronic obstructive pulmonary disease (COPD). Collegian 2004;11:1216.

37 Celis G, Lodewijckx C, Schoonis A, Decramer M. Clinical pathway for acute COPD exacerbations reduces hospital stay and readmission; 2007. [http://www.bvpvsbip.be/pdf\%20bestanden/ers2006_geert.pdf]

38 Marley AM. A care pathway for COPD. Professional Nurse 2000;16:821-823.

39 Siafkas, N. Management of exacerbation of chronic obstructive pulmonary disease. Sheffield, European Respiratory Society Ltd, 2006.

40 Map of Medicine. Management of acute exacerbation; Londen, Map of Medicine, 2009. [http://www.mapofmedicine.com]

41 Rodriguez-Roisin R. COPD exacerbations: management. Thorax 2006;61:535-544.

42 Cook DA, Beckman TJ. Reflections on experimental research in medical education. Adv Health Sci Educ Theory Pract 2008.

43 Polit D, Hungler B. Research Designs for Quantitative studies. In Polit D, Hungler B, (eds): Nursing Research: Principles and methods. Philadelphia, Lippincot Williams \& Wilkins, 1997, pp 175-218.

44 Trochim W. Single Group Threats. In Research Methods Knowledge Base (Trochim W, ed.), Cornell University Cornell University, 2006. [http://www.socialresearchmethods.net/kb/intsing.php] 
45 Medical Research Council (MRC). Cluster Randomised Trials: Methodological and ethical considerations. Medical Research Council (MRC) 2002. [http://open.mrc.gm/Statsdatamgt/stats\&datam_files/MRCguide_cluster.pdf]

46 Hallberg IR. Challenges for future nursing research: providing evidence for health-care practice. Int J Nurs Stud 2006;43:923-927.

47 Trochim W. External validity. In Research Methods Knowledge Base (Trochim W, ed.), Cornell University, 2006. [http://www.socialresearchmethods.net/kb/external.php]

48 Craig P, Dieppe P, Macintyre S, Michie S, Nazareth I, Petticrew M. Developing and evaluating complex interventions: the new Medical Research Council guidance. BMJ 2008;337:a1655.

49 Panella M, Vanhaecht K. Is there still need for confusion about pathways? Intl J Care Pathw 2010;14:1-3.

50 Berwick DM. The science of improvement. JAMA 2008;299:1182-1184.

51 Campbell NC, Murray E, Darbyshire J, Emery J, Farmer A, Griffiths F, Guthrie B, Lester $\mathrm{H}$, Wilson $\mathrm{P}$, Kinmonth $\mathrm{AL}$. Designing and evaluating complex interventions to improve health care. BMJ 2007;334:455-459.

52 Panella M, Marchisio S, Gardini A, Di SF. A cluster randomized controlled trial of a clinical pathway for hospital treatment of heart failure: study design and population. BMC Health Serv Res 2007;7:179.

53 Rotter T, Kinsman L, James E, Machotta A, Willis J, Snow P, Kugler J. Have we drawn the wrong conclusions about the value of care pathways? Is a Cochrane review appropriate? Response to the commentary article published by Kris Vanhaecht et al. Eval Health Prof 2012;35:43-46.

54 Cella DF, Perry SW. Reliability and concurrent validity of three visual-analogue mood scales. Psychol Rep 1986;59:827-833.

55 Vanhaecht K, Sermeus W, Peers J, Deneckere S, Lodewijckx C, Leigheb F, Panella M. The European Quality of Care Pathways (EQCP) Study: history, project managment and approach. Intl J Care Pathw 2010;14:52-56.

56 Vanhaecht K, Sermeus W, Peers J, Lodewijckx C, Deneckere S, Leigheb F, Decramer M, Panella M. The impact of care pathways for exacerbation of Chronic Obstructive Pulmonary Disease: rationale and design of a cluster randomized controlled trial. Trials 2010;11:111.

57 Deneckere S, Euwema M, Lodewijckx C, Panella M, Sermeus W, Vanhaecht K. The European quality of care pathways (EQCP) study on the impact of care pathways on interprofessional teamwork in an acute hospital setting: study protocol: for a cluster randomised controlled trial and evaluation of implementation processes. Implement Sci 2012;7:47. 


\section{Chapter 4:}

Quality indicators for in-hospital management of exacerbation of chronic obstructive pulmonary disease: results of an international Delphi study

This chapter is published and reproduced with the kind permission of the editor:

Lodewijckx C, Sermeus W, Panella M, Deneckere S, Leigheb F, Troosters T, Boto PAF, Mendez RV, Decramer M, Vanhaecht K. Quality indicators for in-hospital management of exacerbation of chronic obstructive pulmonary disease: results of an international Delphi study. J Adv Nurs. 2012. Accepted for publication 21 April 2012. 


\section{Abstract}

Background. Management of patients hospitalized with exacerbation of chronic obstructive pulmonary disease is suboptimal and outcomes are poor. To evaluate the impact of care pathways properly, relevant indicators need to be selected.

Objective. To report a Delphi study that was conducted to select process and outcome indicators that are relevant to study quality of care and impact of care pathways for patients hospitalized with exacerbation of chronic obstructive pulmonary disease.

Methods. The study was conducted over 4 months in 2008, with 35 experts out of 15 countries, including 19 medical doctors, 8 nurses and 8 physiotherapists. Participants were asked to rate, for 72 process and 21 outcome indicators, the relevance for follow-up in care pathways for in-hospital management of exacerbation of chronic obstructive pulmonary disease. Consensus (agreement by at least $75 \%$ of the participants) that an indicator is relevant for follow-up was sought in two rounds.

Results. Consensus was reached for 26 of 72 process indicators $(36.1 \%)$ and 10 of 21 outcome indicators (47.6\%). Highest consensus levels were found for the process indicators regarding oxygen therapy (100\%), pulmonary rehabilitation $(100 \%)$ and patient education $(94.5-88.6 \%)$ and for the outcome indicators concerning understanding of therapy (91.4$85.7 \%)$ and self-management (88.6-88.2\%).

Conclusions. The selected indicators appear to be sensitive for improvement. Therefore, researchers and clinicians that want to study and improve the care for patients hospitalized with exacerbation of chronic obstructive pulmonary disease should primarily focus on these indicators. 


\section{Introduction}

Chronic obstructive pulmonary disease (COPD) is a disease state characterized by airflow limitation that is not fully reversible [1]. Worldwide, the disease affects $9.8 \%$ of men and $5.6 \%$ of women [2] and is a leading cause of morbidity and mortality [3].

Patients with COPD experience frequent exacerbations of symptoms, varying from 0.5 3.5 a year [4-6]. COPD exacerbations are characterized by a change in baseline dyspnoea, cough and/or sputum that is beyond normal day-to-day variations; is acute in onset; and may warrant additional treatment in a patient with underlying COPD [7]. COPD exacerbations contribute tremendously to the disease burden. They are a leading cause of hospital admission worldwide, with $35 \%$ of COPD patients having at least one admission a year and up to $40 \%$ of admitted patients having two or more readmissions a year [5;8;9].

Studies about in-hospital management of COPD exacerbations have shown suboptimal performance of care activities recommended by worldwide accepted guidelines, especially for arterial blood gas measurement, administration of corticosteroids, smoking cessation, patient education and referral to pulmonary rehabilitation [10-12]. Similarly, studies about outcomes in patients hospitalized due to a COPD exacerbation have demonstrated poor and varying outcomes, especially for 6-month readmission (30-43\%) [13-15]; 30-day mortality (5.2-17.2\%) [16]; and 1-year mortality (23-37\%) [14;15].

A possible strategy to optimize care processes and to improve outcomes is the implementation of a care pathway, also known as critical pathway or clinical pathway [17-20]. Care pathways are 'complex interventions for the multidisciplinary decision-making and organization of predictable care for a well-defined group of patients during a well-defined period, with the aim to enhance the quality of care across the continuum by improving riskadjusted patient outcomes, promoting patient safety, increasing patient satisfaction and optimizing the use of resources' [21].

Although care pathways are used worldwide [22-25], the effectiveness of care pathways for in-hospital management of COPD exacerbation is not known. A recent literature review on care pathways for COPD exacerbation revealed only four studies [26]. Three studies used a pre-posttest design; the fourth study was a non-randomized controlled trial comparing an experimental group where patients were treated according to a care pathway with a control group where usual care was provided. The studies described few positive effects of the care pathways on diagnostic processes and on clinical outcomes. Although, due to follow-up of very few and diverse indicators, limited statistical analysis and weak design of the studies, the internal validity of results is limited and so reliable conclusions could not be drawn [26]. Therefore, appropriately designed research like a cluster randomized controlled trial is needed to evaluate the impact of COPD care pathways on performance of care processes and clinical outcomes ([27;28]. To study quality of care and impact of care pathways for 
patients hospitalized with COPD exacerbation appropriately, a valid and feasible set of process and outcome indicators needs to be defined [29-31].

\section{Methods}

\section{Objective}

The aim of this Delphi study was to select process and outcome indicators that are relevant to study quality of care and impact of care pathways for patients hospitalized with COPD exacerbation.

\section{Design}

To select relevant process and outcome indicators, the Delphi consensus method was used. This method, which rigorously solicits and synthesizes expert opinion, is recommended in areas of knowledge where methodologically rigorous research evidence is limited and experts disagree on its interpretation. The Delphi method is a group facilitation technique designed to transform individual opinions into group consensus and includes two or more postal rounds of questionnaires. With this technique, a large group of experts can be consulted from a geographically dispersed population [29;32;33]. In this Delphi survey, consensus on relevance of indicators for follow-up in care pathways for COPD exacerbation was sought in two rounds of questionnaires (Figure 1)

\section{Participants}

The objective was to generate an international and multidisciplinary Delphi panel of medical doctors, nurses and physiotherapists [32;33]. Selection of the participants occurred by purpose sampling and was performed by a medical doctor, a clinical nurse specialist and a physiotherapist with internationally recognized experience and networking in COPD care.

For the selection of the medical doctors, members of the committee of the Global Initiative for Chronic Obstructive Lung Disease and the authors who contributed to the European Respiratory Monograph booklet regarding management of COPD were contacted $[1 ; 34]$. The nursing group and the physiotherapists were selected by contacting the allied respiratory professionals, assembly representatives of respective nurses and physiotherapists of the European Respiratory Society (http://www.ersnet.org). Finally, the first authors of the trials included in the reviews about 'adherence to international guidelines' [12] and about 'Impact of COPD care pathways' [26] were contacted.

To avoid major influence of organizational factors such as professional culture and clinical practice in organizations, we included for each of the three disciplines the criterion 
that experts from the same country had to be affiliated with different organizations. Also, the authors of this article were not part of the expert panel.

Figure 1. The Delphi Survey

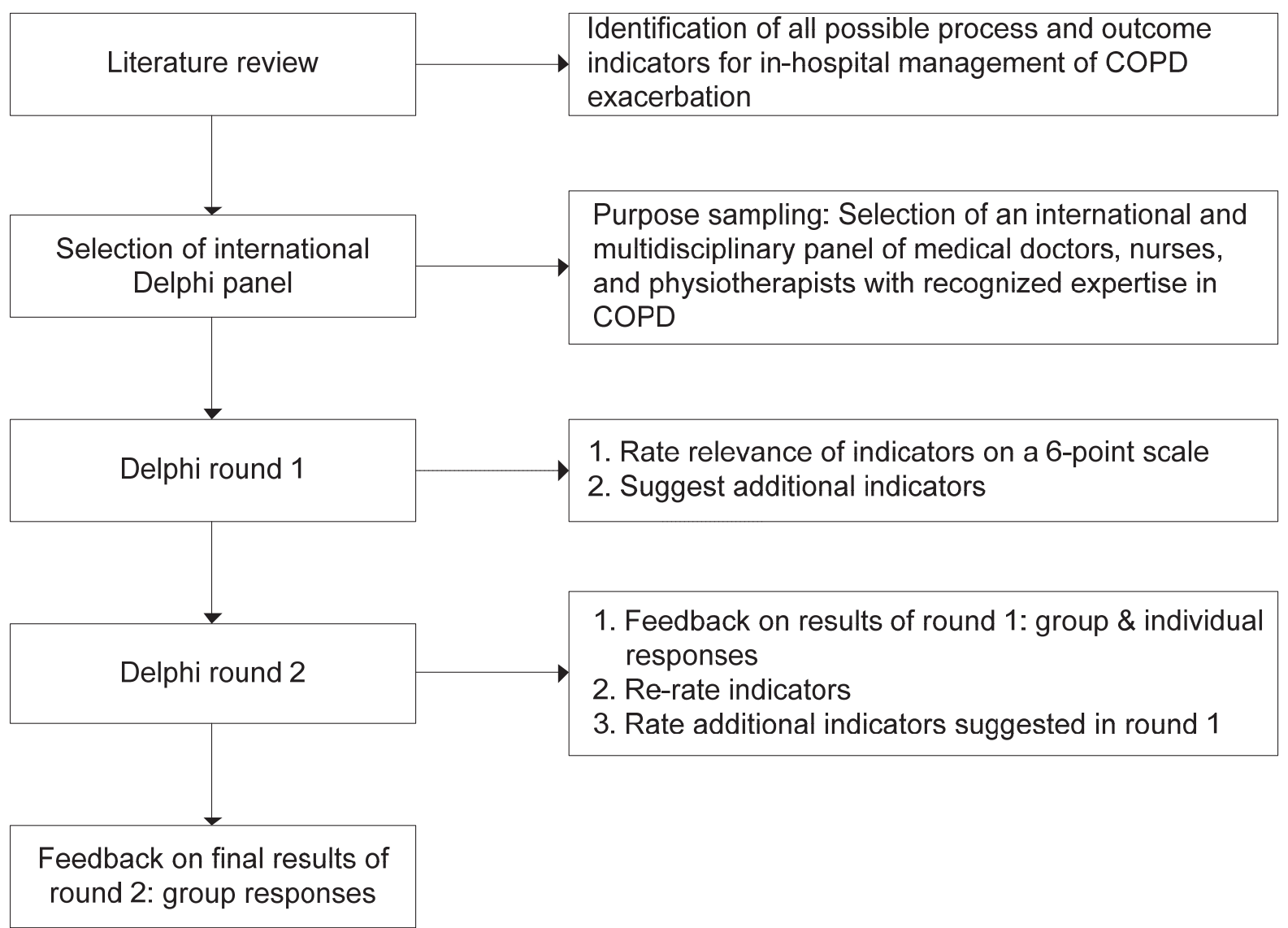

\section{Delphi questionnaire and rating}

To develop a Delphi questionnaire including all possible process and outcome indicators for in-hospital management The objective was to generate an international and multidisciplinary Delphi panel of medical doctors, nurses and of COPD exacerbations, an extensive literature review was conducted by the first author. The following resources were explored: (i) Websites of international respiratory societies: American Thoracic Society (ATS), British Thoracic Society (BTS), European Respiratory Society (ERS), Global Strategy for Diagnosis, Management and Prevention of COPD (GOLD), National Institute for Health and Clinical Excellence (NICE) and (ii) Electronic databases: Medline, EMBASE, Cochrane library, CINAHL. The following search terms were used: COPD, disease exacerbation, management, patient care management, practice guideline and outcomes. Applied limits included: published between 2003-2008; written in English, French, German, Italian or Dutch; and (iii) Map of Medicine (http://www.mapofmedicine.com). A two level screening of the publications was applied. Firstly, publications were assessed on relevance based on review of the title 
and abstract. Subsequently, the full text of the selected guidelines, reviews or process flows were reviewed. Following inclusion criteria were applied: (i) description of management or outcomes of patients hospitalized with COPD exacerbation; (ii) process indicators: evidence was reported in terms of guidelines, reviews or process flows; (iii) published between 20032008; (iv) published in English, French, German; Italian or Dutch; and (v) possible to assess strength of recommendations and the quality of the evidence.

As result five clinical practice guidelines [1;34-37]; two process flows (Map of Medicine, 2009721 /id; Map of Medicine, 2009721 /id\}; and 12 outcome studies were included [8;9;15;38-42]. Based on the selected literature, 72 process and 21 outcome indicators were identified.

The Delphi questionnaire, based on the literature search, included three main parts: 72 process indicators; 21 outcome indicators; and 9 demographic questions (city, country, name and type of organization, number of beds, professional group, years of experience, age and gender) (see appendix 1). The provisional Delphi questionnaire was pretested by a medical doctor, a nurse and a physiotherapist. These experts did not participate in the expert panel. Based on their feedback, the questionnaire was adapted where needed and a final version was constructed for surveying the expert panel.

For the first part with the 72 process indicators, experts were asked to rate, on a 6-point scale, what impact they believe that the listed processes have on clinical outcomes and therefore how relevant they believe that these process indicators are for follow-up in studies investigating quality of in-hospital management of COPD exacerbation. Score ' 1 ' meant 'low impact on outcomes and thus not relevant,' and score ' 6 ' meant 'high impact on outcomes and thus highly relevant.' For the second part with the 21 outcome indicators, experts were asked to rate, on a 6-point scale, how sensitive to change they believe the listed outcome indicators would be when implementing a COPD care pathway and therefore how relevant they believe that these outcome indicators are for follow-up in studies investigating quality of in-hospital management of COPD exacerbations. Score ' 1 ' meant 'low sensitive to change and thus not relevant,' and score ' 6 ' meant 'high sensitive to change and so highly relevant.' A 6-point rating scale was used to avoid a tendency to score 'in the middle' [43]. Panellists were also offered the opportunity to suggest additional process and outcome indicators, or other remarks concerning the Delphi questionnaire.

\section{Content validity index and consensus}

The content validity index $(\mathrm{CVI})$ refers to the proportion of experts who are in agreement about content validity and thus relevance of a specific item [44]. In this study, CVI for a specific indicator refers to that proportion of experts that scored 5 or 6 for that indicator. A CVI of $75 \%$ or higher in round 2 was considered to be consensus by the panel that an 
indicator is relevant for follow-up in COPD exacerbation care pathways [32]. This cut-off point was defined at the outset of the study.

\section{Delphi survey}

The Delphi survey was conducted by electronic mail between September 2008-December 2008 [32]. At the outset of the study, it was decided that the Delphi survey would include two rounds of responses (Figure 1) [32;33]. Invitation for participation in the Delphi study, together with explanation about the aim of the study and the Delphi procedure was included in the mailing of round 1 [32]. Also, as background information, the GOLD guidelines were included. These are evidence-based guidelines for COPD diagnosis, management and prevention, developed by GOLD (2009). For each mailing round, panellists were asked to return the completed datasheets in 2 weeks. Confidentially was guaranteed in this way that respondents will be known to the researcher and even to one another, but their judgments and opinions remain strictly confidential [45].

For the first round, according to each discipline, the panelists were contacted by three recognized leaders of the European Respiratory Society (ERS) (http://www.ersnet.org), namely the vice president (MD), the secretary of the ERS assembly group 'Physiotherapists' and the chair of the ERS assembly group 'Nurses'. We believed this mailing strategy would increase the response rate [32;33]. The mailing for round 2 was sent by the main researcher (CL). A reminder was sent 1 month after the initial mailing [32].

In the first round, the panellists were asked to rate the relevance of each process and outcome indicator and to provide the demographic information. In round 2, feedback on the round 1 responses was provided to all panellists, presented by following summary statistics: number of respondents who answered the questionnaire; number of respondents who rated 1 or 2,3 or 4 and 5 or 6 (percentage); central tendencies (median, mode); and the respondent's own responses [32;33]. Using this information, respondents were asked to rerate the indicators in case they wanted to change their previous answer. Experts were also asked to rate the process and outcome indicators suggested by the respondents in round 1 . The results of round 2 were considered as the final results of the Delphi survey. If participants of round 1 did not respond in round 2, their answers of round 1 were considered as final answers.

In a final and third mailing, feedback on the final group results was provided. This included a final list of all process and outcome indicators for which consensus (CVI $\geq 75 \%$ ) was obtained, or in other words, all the indicators that were rated 5 or 6 by at least $75 \%$ of the panellists in round 2. Also an overview of the involved experts was provided. Ethical considerations 
The research protocol was approved by the research ethics committee at Leuven University (identifier: ML5617). Consent to participation was considered to be present when the participant returned the questionnaire. To inform potential participants in a proper manner, we provided one sheet with explanation and aim of the study, their involvement in it, how the Delphi works and what was expected of them. Finally, to respect privacy of each participant, it was guaranteed to the panellists that their judgments and opinions would remain strictly confidential [45].

\section{Data analysis}

Results were analysed and presented in two ways: results obtained by the overall panel and results obtained per discipline. Descriptive statistics were used to report the expert panel responses. To assess the differences in CVIs between the three disciplines, $P$ values from the Kruskal-Wallis exact test were calculated. Two-tailed tests were used and $P$ values were considered statistically significant if $P<0.05$. If important differences were found, a post hoc Mann-Whitney U-test was performed to assess which pairs of groups had important differences. Finally, to adjust for multiple testing, the Bonferroni correction was used; consequently $P$ values were considered statistically significant if $P<0.017$. Data were analysed using the statistical software program SPSS version 16.0 [IBM SPSS Statistics 19 International Business Machines Corporation (IBM)., Armonk, NY, USA].

\section{Results}

\section{Participant characteristics}

In round 1,35 of 50 contacted experts returned the questionnaire (response rate: $70.0 \%$ ). The panel included representatives from three continents (Table 1) and 15 countries: Australia $(n=1)$, Belgium $(n=4)$, France $(n=2)$, Germany $(n=2)$, Greece $(n=1)$, Ireland $(n$ $=1)$, Italy $(n=1)$, Poland $(n=1)$, Portugal $(n=1)$, Spain $(n=2)$, Sweden $(n=1)$, the Netherlands $(n=2)$, Turkey $(n=1)$, UK $(n=11)$ and USA $(n=4)$. The respondents included 19 medical doctors (54.3\%), 8 nurses (22.9\%) and 8 physiotherapists $(22.9 \%)$. All respondents had at least 5 years of experience in respiratory care, with $77.1 \%$ of the experts reporting 15 years or more of experience. Twenty-five panellists $(71.4 \%)$ were affiliated with academic hospitals and $4(11.4 \%)$ with community teaching hospitals. Other affiliated organizations were respiratory physiotherapy centres $(n=2)$, primary care trusts $(n=2)$ and research centres for medical studies $(n=2)$. The number of beds in the 29 hospitals varied from less than 200 beds $(31.0 \%)$ to 800 beds and more $(27.6 \%)$. In round 2, 31 of 35 panellists who participated in round 1 returned the completed questionnaire (response rate: 
$88.6 \%$ ), including 17 of 19 medical doctors (89.5\%), 6 of 8 nurses $(75.0 \%)$ and all 8 physiotherapists $(100 \%)$.

Table 1. Characteristics of the Delphi panel $(n=35)$

\begin{tabular}{|lr|}
\hline Characteristics & $\mathbf{n}(\mathbf{( \% )}$ \\
\hline Sex & $22(62.9)$ \\
Male & $13(37.1)$ \\
Female & \\
Age $^{*}$ & $14(40.0)$ \\
$30-49$ & $19(54.3)$ \\
$50-69$ & $1(2.9)$ \\
$\geq 70$ & $19(54.3)$ \\
Discipline & $8(22.9)$ \\
Medical doctor & $8(22.9)$ \\
Nurse & \\
Physiotherapist & $7(20.0)$ \\
Years of experience in respiratory care & $11(31.4)$ \\
$5-14$ & $11(31.4)$ \\
$15-24$ & $5(14.3)$ \\
$25-34$ & \\
$\geq 40$ & $25(71.4)$ \\
Type of institution & $4(11.4)$ \\
Academic hospital & $2(5.7)$ \\
Community teaching hospital & $2(5.7)$ \\
Respiratory physiotherapy center & $2(5.7)$ \\
Primary care trust & \\
Research center for medical studies & $30(85.7)$ \\
Number of beds, $n$ (\%) & \\
$<200$ & $4(11.4)$ \\
$200-399$ & $9(31.0)$ \\
$400-599$ & $5(17.2)$ \\
$600-799$ & $6(20.7)$ \\
$\geq 800$ & $5(17.2)$ \\
Continent, $n$ (\%) & $8(27.6)$ \\
Australia & \\
Europe & \\
North America & \\
\hline
\end{tabular}

${ }^{*} \mathrm{n}=34$ (missing: $\mathrm{n}=1 ; 2.9 \%$ ).

${ }^{\dagger} n=29$ hospitals.

\section{Results of the overall panel: process indicators}

Experts reached consensus ( $\mathrm{CVI} \geq 75 \%$ ) for 26 of 72 process indicators (36.1\%). Table 2 lists the indicators in descending order of the CVIs. A CVI of $100 \%$ was reached for three process indicators: 'controlled oxygen therapy', 'initiation of long-term oxygen therapy (LTOT)', and 'referral to pulmonary rehabilitation'. Also, a CVI of more than $90 \%$ was 
reached for five other process indicators: 'education about recognition and treatment of exacerbations' (97.1\%), 'identification for pulmonary rehabilitation' (94.3\%), 'education about inhaler therapy' (94.3\%), 'smoking cessation advice when active smoker' (91.4\%) and 'treatment of comorbid conditions' (91.4\%).

Table 2 also displays the CVIs obtained after round 1. Ten indicators shifted from CVI $<75 \%$ in round 1 to consensus (CVI $\geq 75 \%$ ) in round 2 (Table 2, nos. 9, 11, 15, 19, 20, 22, 23, 24, 25, 26). Furthermore, for all other indicators, except for 'arterial blood gas measurement at admission' (Table 2, no. 21), CVIs increased from 5-10\% in round 2.

Four other process indicators were suggested by participants in round 1: 'glucose control', 'assessment and management of anxiety and depression', 'patient education about coping strategies for possible depression and self-management' and 'monitoring following discharge for at least 2 weeks'. In the second round no consensus was reached for these additional indicators.

\section{Results of the overall panel: outcome indicators}

Consensus ( $C V I \geq 75 \%$ ) was reached by the overall panel for 10 of 21 outcome indicators (47.6\%). Table 2 also lists the outcome indicators in descending order of the CVIs. A CVI of $91.4 \%$ was obtained for the indicator 'correct use of inhaler therapy'. Six indicators reached a CVI between $85-89 \%$ : 'successful management at home' $(88.6 \%)$, 'able to cope in usual environment' $(88.2 \%)$, 'correct use of oral therapy' $(85.7 \%)$, 'correct use of oxygen therapy (85.7\%), 'interval before next admission' (85.7\%) and 'health-related quality of life' $(85.7 \%)$.

Outcome indicators for which consensus $(\mathrm{CVI} \geq 75 \%)$ was obtained in round 1 were the same in round 2; however, CVIs of 8 of the 10 outcome indicators $(80 \%)$ increased in round 2 (Table 2). Six additional indicators were suggested by the panellists: 'fat-free mass index (FMI)', 'fatigue', 'functional status', 'type of social support', 'type of follow-up' and 'unplanned use of healthcare system'. No consensus was reached for these extra indicators in the second round. 
Table 2: Content validity indexes of the process indicators for which consensus was reached by the overall panel*

\begin{tabular}{|c|c|c|}
\hline Indicators & $\begin{array}{c}\text { Content } \\
\text { validity } \\
\text { index* } \\
\text { ROUND } 1 \\
\text { n/n (\%) }\end{array}$ & $\begin{array}{c}\text { Content } \\
\text { validity } \\
\text { index* } \\
\text { ROUND } 2 \\
\text { n/n (\%) }\end{array}$ \\
\hline \multicolumn{3}{|l|}{ Process indicators: } \\
\hline 1. Controlled oxygen therapy in hypoxemic patients & $31 / 35(88.6)$ & $35 / 35(100)$ \\
\hline $\begin{array}{l}\text { 2. Initiation of long-term oxygen therapy (LTOT) if the patient } \\
\text { remains hypoxemic }\end{array}$ & $30 / 35(85.7)$ & $35 / 35100)$ \\
\hline 3. Referral to pulmonary rehabilitation & $34 / 35(97.1)$ & $35 / 35(100)$ \\
\hline $\begin{array}{l}\text { 4. Patient education: Information about recognition and treatment } \\
\text { of exacerbations }\end{array}$ & $32 / 35(91.4)$ & $34 / 35(97.1)$ \\
\hline 5. Identification for pulmonary rehabilitation & $31 / 35(88.6)$ & $33 / 35(94.3)$ \\
\hline $\begin{array}{l}\text { 6. Patient education: Instruction on how to use inhalers and other } \\
\text { treatments }\end{array}$ & $31 / 35(88.6)$ & $33 / 35(94.3)$ \\
\hline 7. Smoking cessation advice when active smoker & $30 / 35(85.7)$ & $32 / 35(91.4)$ \\
\hline 8. Treatment of comorbid conditions & $31 / 35(88.6)$ & $32 / 35(91.4)$ \\
\hline $\begin{array}{l}\text { 9. Medical history before exacerbation: Number of previous } \\
\text { exacerbations in the previous year }\end{array}$ & $25 / 35(71.4)$ & $31 / 35(88.6)$ \\
\hline 10.Medical history before exacerbation: Pre-existing comorbidities & $27 / 35(79.4)$ & $31 / 35(88.6)$ \\
\hline $\begin{array}{l}\text { 11.Pulse oximetry: Prior to discharge in patients hypoxemic during } \\
\text { a COPD exacerbation }\end{array}$ & $26 / 35(74.3)$ & $31 / 35(88.6)$ \\
\hline $\begin{array}{l}\text { 12.Appropriate prescription of long-acting bronchodilatators (B- } \\
\text { agonists and/or anticholinergics) }\end{array}$ & $28 / 35(80.0)$ & $31 / 35(88.6)$ \\
\hline 13.Antibiotics in patients if indicated & $29 / 35(82.9)$ & $31 / 35(88.6)$ \\
\hline 14.Patient education: Information about oxygen treatment & $27 / 35(77.1)$ & $31 / 35(88.6)$ \\
\hline $\begin{array}{l}\text { 15. Medical history before exacerbation: Documentation of possible } \\
\text { limitation of daily activities }\end{array}$ & $26 / 35(74.3)$ & $30 / 35(85.7)$ \\
\hline $\begin{array}{l}\text { 16. Appropriate prescription of glucocorticosteroids: Oral or } \\
\text { intravenous }\end{array}$ & $25 / 35(75.8)$ & $30 / 35(85.7)$ \\
\hline 17.Physiotherapy: Activities of Daily Life & $28 / 35(80.0)$ & $30 / 35(85.7)$ \\
\hline 18.Assessment of differential diagnosis & $28 / 35(80.0)$ & $30 / 35(85.7)$ \\
\hline 19.Medical history before exacerbation: Cardiovascular status & $24 / 35(68.6)$ & 29/35 (82.9) \\
\hline 20.Pulse oximetry at admission & $24 / 35(68.6)$ & 29/35 (82.9) \\
\hline 21. Arterial blood gas measurement at admission & $29 / 35(82.9)$ & 29/35 (82.9) \\
\hline $\begin{array}{l}\text { 22. Arterial blood gas measurement: Prior to discharge in patients } \\
\text { hypoxemic during a COPD exacerbation }\end{array}$ & $24 / 35(70.6)$ & $29 / 35(82.9)$ \\
\hline 23. Fluid administration in dehydrated patients & $26 / 3574.3)$ & 29/35 (82.9) \\
\hline 24.Assessment of symptoms & $23 / 35(65.7)$ & $28 / 35(80.0)$ \\
\hline 25.Assessment and management of social situation & $26 / 35(74.3)$ & $28 / 35(80.0)$ \\
\hline 26.Patient education: Information about the nature of COPD & $22 / 35(62.9)$ & $28 / 35(80.0)$ \\
\hline \multicolumn{3}{|l|}{ Outcome indicators: } \\
\hline $\begin{array}{l}\text { 1. Patient and/or home caregiver fully understands correct use of } \\
\text { inhaler }\end{array}$ & $30 / 35(85.7)$ & $32 / 35(91.4)$ \\
\hline 2. Patient, family, and physician are confident that the patient can & $28 / 35(80.0)$ & $31 / 35(88.6)$ \\
\hline
\end{tabular}


manage successfully at home

3. Able to cope in usual environment

4. Patient and/or home caregiver fully understand correct use of oral therapy

5. Patient and/or home caregiver fully understand correct use of inhaler therapy

6. Patient and/or home caregiver fully understand correct use of oxygen therapy (LTOT)

7. Interval before next admission

8. Health-related Quality of Life

9. Patient, if previously ambulatory, is able to cope with basic needs in his/her situation

10.Mortality within one year after exacerbation

\begin{tabular}{l|l}
$26 / 35(76.5)$ & $30 / 35(88.2)$ \\
$30 / 35(85.7)$ & $30 / 35(85.7)$ \\
$28 / 35(80.0)$ & $30 / 35(85.7)$ \\
$27 / 35(77.1)$ & $30 / 35(85.7)$ \\
$26 / 35(76.5)$ & $30 / 35(85.7)$ \\
$24 / 35(70.6)$ & $30 / 35(85.7)$ \\
$27 / 35(77.1)$ & $28 / 35(80.0)$ \\
$30 / 35(85.7)$ & $28 / 35(80.0)$
\end{tabular}

${ }^{*}$ Content validity index (CVI): Proportion of experts scoring 5 or 6 for a specific indicator (score of 5 or 6 means that the indicator is scored as highly relevant for follow-up); Consensus: CVI $\geq 75 \%$ obtained in round 2 .

\section{Results per discipline: process indicators}

Medical doctors reached consensus ( $C V I \geq 75 \%$ ) for 22 of 72 process indicators $(30.6 \%)$ and nurses and physiotherapists each for 40 of 72 indicators (55.6\%). Table 3 lists all process and outcome indicators for which consensus was reached in each professional group. The indicators are presented in descending order of the CVIs of the medical doctors, because this discipline was mostly represented in the panel (Table 1) and because 39 of 72 scored indicators $(54.2 \%)$ included strict medical indicators. The Kruskal-Wallis test, performed for all 72 scored process indicators, revealed 12 important differences in CVls between disciplines, varying from differences of $5 \%$ to $70 \%$ (Table 3 , nos. $5,8,14,22,24,26,33,38$, $40,42,43)$. One important difference was not displayed in the table, namely 'medical history: documenting frequency and severity of cough,' as no consensus was reached for this indicator by any of the three disciplines. CVIs for this indicator of medical doctors, nurses and physiotherapists were, respectively, $5.3 \%, 25.0 \%$ and $0.0 \%(P=0.026)$.

After Mann-Whitney U-tests with Bonferroni correction, eight important differences in CVIs between disciplines were found (Table 4). These included differences in CVIs of 30 $60 \%$ between medical doctors and physiotherapists about hydration, nutrition, education and physiotherapy (Table 4, nos. 2, 3, 4 and 5) and a difference of more than $60 \%$ between medical doctors and nurses concerning deep venous prophylactics (Table 4, no. 7). 
Table 3: Content validity indexes of process and outcome indicators for which consensus was reached by medical doctors, nurses, and physiotherapists*

\begin{tabular}{|c|c|c|c|c|}
\hline & \multicolumn{3}{|c|}{$\begin{array}{c}\text { Content validity index*T } \\
\text { ROUND } 2\end{array}$} & \multirow[b]{2}{*}{ P§ } \\
\hline & $\begin{array}{l}\text { Medical } \\
\text { doctors } \\
\mathrm{n} / \mathrm{n}(\%)\end{array}$ & $\begin{array}{l}\text { Nurses } \\
\text { n/n (\%) }\end{array}$ & $\begin{array}{l}\text { Physio- } \\
\text { therapists } \\
\text { n/n (\%) }\end{array}$ & \\
\hline Process indicators $^{\dagger}$ & & & & \\
\hline $\begin{array}{l}\text { 1. Controlled oxygen therapy in hypoxemic } \\
\text { patients }^{\ddagger}\end{array}$ & $19 / 19(100)$ & $8 / 8(100)$ & $8 / 8(100)$ & 1.000 \\
\hline $\begin{array}{l}\text { 2. Initiation of long-term oxygen therapy (LTOT) } \\
\text { if the patient remains hypoxemic }{ }^{\ddagger}\end{array}$ & $19 / 19(100)$ & $8 / 8(100)$ & $8 / 8(100)$ & 0.336 \\
\hline 3. Referral to pulmonary rehabilitation ${ }^{\ddagger}$ & $19 / 19(100)$ & $8 / 8(100)$ & $8 / 8(100)$ & 0.065 \\
\hline 4. Treatment of comorbid conditions ${ }^{\ddagger}$ & $19 / 19(100)$ & $6 / 8(75.0)$ & $7 / 8(87.5)$ & 0.885 \\
\hline $\begin{array}{l}\text { 5. Patient education: Information about } \\
\text { recognition and treatment of exacerbations }{ }^{\ddagger}\end{array}$ & $18 / 19(94.7)$ & $8 / 8(100)$ & $8 / 8(100)$ & 0.048 \\
\hline $\begin{array}{l}\text { 6. Medical history before exacerbation: Number } \\
\text { of previous exacerbations in the previous } \\
\text { year }^{\ddagger}\end{array}$ & $18 / 19(94.7)$ & $7 / 8(87.5)$ & $6 / 8(75.0)$ & 0.128 \\
\hline $\begin{array}{l}\text { 7. Medical history before exacerbation: Pre- } \\
\text { existing comorbidities }^{\ddagger}\end{array}$ & $18 / 19(94.7)$ & $7 / 8(87.5)$ & $6 / 8(75.0)$ & 0.803 \\
\hline 8. Identification for pulmonary rehabilitation ${ }^{\ddagger}$ & $17 / 19(89.5)$ & $8 / 8(100)$ & $8 / 8(100)$ & 0.026 \\
\hline $\begin{array}{l}\text { 9. Patient education: Instruction on how to use } \\
\text { inhalers and other treatments }{ }^{\ddagger}\end{array}$ & $17 / 19(89.5)$ & $8 / 8(100)$ & $8 / 8(100)$ & 0.170 \\
\hline $\begin{array}{l}\text { 10. Smoking cessation advice when active } \\
\text { smoker }^{\ddagger}\end{array}$ & $17 / 19(89.5)$ & $7 / 8(87.5)$ & $8 / 8(100)$ & 0.575 \\
\hline 11. Assessment of differential diagnosis ${ }^{\ddagger}$ & $17 / 19(89.5)$ & $7 / 8(87.5)$ & $6 / 8(75.0)$ & 0.813 \\
\hline $\begin{array}{l}\text { 12. Medical history before exacerbation: } \\
\text { Cardiovascular status }{ }^{\ddagger}\end{array}$ & $17 / 19(89.5)$ & $6 / 8(75.0)$ & $6 / 8(75.0)$ & 0.462 \\
\hline $\begin{array}{l}\text { 13. Appropriate prescription of long-acting } \\
\text { bronchodilatators (B-agonists and/or } \\
\text { anticholinergics) }\end{array}$ & $16 / 19(84.2)$ & $8 / 8(100)$ & $7 / 8(87.5)$ & 0.463 \\
\hline 14. Antibiotics in patients if indicated ${ }^{\ddagger}$ & $16 / 19(84.2)$ & $8 / 8(100)$ & $7 / 8(87.5)$ & 0.046 \\
\hline $\begin{array}{l}\text { 15. Patient education: Information about oxygen } \\
\text { treatment }^{\ddagger}\end{array}$ & $16 / 19(84.2)$ & $8 / 8(100)$ & $7 / 8(87.5)$ & 0.347 \\
\hline $\begin{array}{l}\text { 16. Appropriate prescription of } \\
\text { glucocorticosteroids: Oral or intravenous }{ }^{\ddagger}\end{array}$ & $16 / 19(84.2)$ & $8 / 8(100)$ & $6 / 8(75.0)$ & 0.436 \\
\hline $\begin{array}{l}\text { 17. Pulse oximetry: Prior to discharge in patients } \\
\text { hypoxemic during a COPD exacerbation }{ }^{\ddagger}\end{array}$ & 15/19 (78.9) & $8 / 8(100)$ & $8 / 8(100)$ & 0.137 \\
\hline $\begin{array}{l}\text { 18. Arterial blood gas measurement at } \\
\text { admission }^{\ddagger}\end{array}$ & $15 / 19(78.9)$ & $7 / 8(87.5)$ & $7 / 8(87.5)$ & 0.842 \\
\hline $\begin{array}{l}\text { 19. Arterial blood gas measurement: Prior to } \\
\text { discharge in patients hypoxemic during a } \\
\text { COPD exacerbation }{ }^{\ddagger}\end{array}$ & $15 / 19(78.9)$ & $6 / 8(75.0)$ & $8 / 8(100)$ & 0.291 \\
\hline $\begin{array}{l}\text { 20. Assessment and management of social } \\
\text { situation }^{\ddagger}\end{array}$ & $15 / 19(78.9)$ & $6 / 8(75.0)$ & $7 / 8(87.5)$ & 0.391 \\
\hline $\begin{array}{l}\text { 21. Pulmonary testing after discharge: } \\
\text { Spirometry }^{\ddagger}\end{array}$ & $15 / 19(78.9)$ & $4 / 8(50.0)$ & $6 / 8(75.0)$ & 0.357 \\
\hline
\end{tabular}




\begin{tabular}{|c|c|c|c|c|}
\hline 22. Deep venous thrombosis prophylaxis & $15 / 19(78.9)$ & $1 / 8(12.5)$ & $5 / 8(62.5)$ & 0.041 \\
\hline $\begin{array}{l}\text { 23. Medical history before exacerbation: } \\
\text { Documentation of possible limitation of daily } \\
\text { activities }^{\ddagger}\end{array}$ & $14 / 19(73.7)$ & $8 / 8(100)$ & $8 / 8(100)$ & 0.070 \\
\hline 24.Physiotherapy: Activities of Daily Life ${ }^{\ddagger}$ & $14 / 19(73.7)$ & $8 / 8(100)$ & $8 / 8(100)$ & 0.016 \\
\hline 25.Pulse oximetry at admission ${ }^{\ddagger}$ & $14 / 19(73.7)$ & $8 / 8(100)$ & $7 / 8(87.5)$ & 0.395 \\
\hline 26. Fluid administration in dehydrated patients ${ }^{\ddagger}$ & $14 / 19(73.7)$ & $7 / 8(87.5)$ & $8 / 8(100)$ & 0.019 \\
\hline $\begin{array}{l}\text { 27.Patient education: Information about the } \\
\text { nature of COPD }\end{array}$ & 14/19 (73.7) & $6 / 8(75.0)$ & $8 / 8(100)$ & 0.571 \\
\hline $\begin{array}{l}\text { 28.Assessment and management for anxiety } \\
\text { and depression }\end{array}$ & $11 / 1668.8$ & $4 / 5(80.0)$ & $5 / 6(83.3)$ & 0.289 \\
\hline 29.Assessment of symptoms ${ }^{\ddagger}$ & $13 / 19(68.4)$ & $7 / 8(87.5)$ & $8 / 8(100)$ & 0.143 \\
\hline 30.Smoking status & $13 / 19(68.4)$ & $7 / 8(87.5)$ & $6 / 8(75.0)$ & 0.203 \\
\hline $\begin{array}{l}\text { 31.Pulse oximetry: In the following three months } \\
\text { in patients hypoxemic } \\
\text { during a COPD exacerbation }\end{array}$ & $13 / 19(68.4)$ & $7 / 8(87.5)$ & $6 / 8(75.0)$ & 0.836 \\
\hline 32.Assessment of comorbidities & $12 / 19(63.2)$ & $6 / 8(75.0)$ & $4 / 8(50.0)$ & 0.503 \\
\hline 33.Physiotherapy: Endurance exercise training & $12 / 19(63.2)$ & $6 / 8(75.0)$ & $7 / 8(87.5)$ & 0.023 \\
\hline Ication: self-management plan & $10 / 16(62.5)$ & $4 / 5(80.0)$ & $5 / 6(83.3)$ & 0.530 \\
\hline $\begin{array}{l}\text { 35. Medical history before exacerbation: Present } \\
\text { treatment regimen }\end{array}$ & $11 / 19(57.9)$ & $7 / 8(87.5)$ & $5 / 8(62.5)$ & 0.538 \\
\hline $\begin{array}{l}\text { 36.Pulse oximetry: After discharge in patients } \\
\text { with LTOT }\end{array}$ & $11 / 19(57.9)$ & $6 / 8(75.0)$ & $6 / 8(75.0)$ & .388 \\
\hline $\begin{array}{l}\text { 37. Appropriate prescription of short-acting } \\
\text { bronchodilators }\end{array}$ & $10 / 19(52.6)$ & $6 / 8$ & $5 / 8(62.5)$ & 0.296 \\
\hline $\begin{array}{l}\text { 38.Patient education: Strategies for minimizing } \\
\text { dyspnea }\end{array}$ & $10 / 19(52.6)$ & $6 / 8(75.0)$ & $8 / 8(100)$ & 0.005 \\
\hline $\begin{array}{l}\text { 39. Referral to dietician in patient with obesity or } \\
\text { cachexy }\end{array}$ & $10 / 19(52.6)$ & $6 / 8(75.0)$ & $7 / 8(87.5)$ & 0.515 \\
\hline $\begin{array}{l}\text { 40.Physiotherapy: Resistance training to } \\
\text { improve skeletal muscle strength }\end{array}$ & $9 / 19(47.4)$ & $6 / 8(75.0)$ & $8 / 8(100)$ & 0.003 \\
\hline $\begin{array}{l}\text { 41. Monitoring following discharge for at least } 2 \\
\text { weeks }\end{array}$ & $3 / 16(37.5)$ & $4 / 5(80.0)$ & $3 / 6(50.0)$ & 0.224 \\
\hline $\begin{array}{l}\text { 42. Supplementary nutrition in patients with } \\
\text { BMI>20 }\end{array}$ & $7 / 19$ (36.8) & $6 / 8(75.0)$ & $8 / 8(100)$ & 0.001 \\
\hline 43.Physiotherapy: Chest physiotherapy & $6 / 19(31.6)$ & $5 / 8(62.5)$ & $8 / 8(100)$ & 0.002 \\
\hline \multicolumn{5}{|l|}{ Outcome indicators: } \\
\hline 1. Able to cope in usu & $17 / 19(89.5)$ & $7 / 8(87.5)$ & $7 / 8(87.5)$ & 0.941 \\
\hline $\begin{array}{l}\text { 2. Patient and/or home caregiver fully } \\
\text { understand correct use of inhaler }\end{array}$ & $16 / 19(84.2)$ & $8 / 8(100)$ & $8 / 8(100)$ & 0.158 \\
\hline $\begin{array}{l}\text { 3. Patient, family, and physician are confident } \\
\text { that the patient can manage successfully at } \\
\text { home }\end{array}$ & $16 / 19(84.2)$ & $7 / 8(87.5)$ & $8 / 8(100)$ & 0.819 \\
\hline 4. Interval before next admission & $16 / 19(84.2)$ & $7 / 8(87.5)$ & $7 / 8(87.5)$ & 0.553 \\
\hline $\begin{array}{l}\text { 5. Patient and/or home caregiver fully } \\
\text { understand correct use of oral therapy }\end{array}$ & $15 / 19(78.9)$ & $8 / 8(100)$ & $7 / 8(87.5)$ & 0.107 \\
\hline $\begin{array}{l}\text { 6. Patient and/or home caregiver fully } \\
\text { understand correct use of inhaler therapy }\end{array}$ & $15 / 19(78.9)$ & $8 / 8(100)$ & $7 / 8(87.5)$ & 0.248 \\
\hline
\end{tabular}




\begin{tabular}{|c|c|c|c|c|}
\hline $\begin{array}{l}\text { 7. Patient and/or home caregiver fully } \\
\text { understand correct use of oxygen therapy } \\
\text { (LTOT) }\end{array}$ & $15 / 19(78.9)$ & $8 / 8(100)$ & $7 / 8(87.5)$ & 0.095 \\
\hline 8. Health-related Quality of Life & $15 / 19$ (78.9) & $8 / 8(100)$ & $7 / 8(87.5)$ & 0.683 \\
\hline 9. Unplanned use of the healthcare system & $11 / 14(78.6)$ & 2/6 (33.3) & $3 / 6(50.0)$ & 0.406 \\
\hline 10. Mortality within one year after exacerbation & $14 / 19(73.7)$ & $7 / 8(87.5)$ & $7 / 8(87.5)$ & 0.690 \\
\hline $\begin{array}{l}\text { 11.Patient, if previously ambulatory, is able to } \\
\text { cope with basic needs in his/her situation }\end{array}$ & $13 / 19(68.4)$ & $7 / 8(87.5)$ & $8 / 8(100)$ & 0.263 \\
\hline $\begin{array}{l}\text { 12.Patient has been clinically stable for } 12-24 \\
\text { hours }\end{array}$ & $13 / 19(68.4)$ & $7 / 8(87.5)$ & $5 / 8(62.5)$ & 0.941 \\
\hline 13.Symptoms at rest and during exercise & $11 / 18(61.1)$ & $5 / 8(62.5)$ & $7 / 8(87.5)$ & 0.125 \\
\hline 14.Patient satisfaction with therapy and care & $10 / 19(52.6)$ & $6 / 8(75.0)$ & $6 / 8(75.0)$ & 0.082 \\
\hline $\begin{array}{l}\text { 15. Patient is able to eat and sleep without } \\
\text { frequent awakening by dyspnea }\end{array}$ & $10 / 19(52.6)$ & $7 / 8(87.5)$ & $7 / 8(87.5)$ & 0.144 \\
\hline 16.Patient satisfaction with therapy and care & $10 / 19(52.6)$ & $6 / 8(75.0)$ & $6 / 8(75.0)$ & 0.082 \\
\hline $\begin{array}{l}\text { 17.Patient's perception of coordination between } \\
\text { hospital and home health care }\end{array}$ & $9 / 19(47.4)$ & $4 / 7(57.1)$ & $6 / 8(75.0)$ & 0.183 \\
\hline 18. Type of social support & $6 / 14(42.9)$ & $4 / 5(80.0)$ & 2/6 (33.3) & 0.321 \\
\hline 19. Length of stay (LOS) & $8 / 19(42.1)$ & $5 / 8(62.5)$ & $6 / 8(75.0)$ & 0.131 \\
\hline 20.Six-minute walking distance & $7 / 19$ (36.8) & $4 / 8(50.0)$ & $6 / 8(75.0)$ & 0.130 \\
\hline
\end{tabular}

${ }^{*}$ Content validity index (CVI): Proportion of experts scoring 5 or 6 for a specific indicator (score of 5 or 6 means that the indicator is scored as highly relevant for follow-up); Consensus: CVI $\geq 75 \%$ obtained in round 2; Italic means no consensus (CVI $<75 \%$ obtained in round 2 )

$\dagger$ Process and outcome indicators are displayed in descending order of CVIs obtained by medical doctors.

$\ddagger$ Indicators for which overall consensus was obtained in round 2 (nos. 1-20; nos. 23-27; no. 29). $\S p$ values were considered significant if $<0.05$.

\section{Results per discipline: outcome indicators}

Concerning outcome indicators, medical doctors reached consensus for 4 of 20 outcome indicators $(20 \%)$, nurses for 13 of 20 indicators $(60.0 \%)$ and physiotherapists for 11 of 20 indicators $(55.0 \%)$ (Table 3$)$. The outcome indicators are also presented in descending order of the CVls of the medical doctors in Table 3. The Kruskal-Wallis test showed no important differences in CVIs between disciplines; however, non-significant differences in consensus of $30 \%$ or more were found for six outcome indicators (Table 3, nos. 9, 11, 15, 18, 19 and 20). 
Table 4: Significant differences in content validity indexes between disciplines after MannWhitney test with Bonferroni correction

\begin{tabular}{|c|c|c|c|c|}
\hline \multirow[t]{2}{*}{ Process indicators } & \multicolumn{3}{|c|}{$\begin{array}{c}\text { Content validity index } \\
\text { ROUND } 2\end{array}$} & \multirow[b]{2}{*}{$P^{\dagger}$} \\
\hline & $\begin{array}{l}\text { Medical } \\
\text { doctors } \\
\mathrm{n} / \mathrm{n}(\%)\end{array}$ & $\begin{array}{l}\text { Nurses } \\
\mathrm{n} / \mathrm{n}(\%)\end{array}$ & $\begin{array}{l}\text { Physio- } \\
\text { therapists } \\
\mathrm{n} / \mathrm{n}(\%)\end{array}$ & \\
\hline 1. Identification for pulmonary rehabilitation & $17 / 19(89.5)$ & & $8 / 8(100)$ & 0.016 \\
\hline 2. Fluid administration in dehydrated patients & $14 / 19(73.7)$ & & $8 / 8(100)$ & 0.011 \\
\hline $\begin{array}{l}\text { 3. Supplementary nutrition in patients with BMI } \\
>20\end{array}$ & $7 / 19(36.8)$ & & $8 / 8(100)$ & 0.000 \\
\hline $\begin{array}{l}\text { 4. Patient education: Strategies for minimizing } \\
\text { dyspnea }\end{array}$ & $10 / 19(52.6)$ & & $8 / 8(100)$ & 0.002 \\
\hline $\begin{array}{l}\text { 5. Physiotherapy: Resistance training to } \\
\text { improve skeletal muscle strength }\end{array}$ & $9 / 19(47.4)$ & & $8 / 8(100)$ & 0.002 \\
\hline 6. Physiotherapy: Chest physiotherapy & $17 / 19(89.5)$ & & $6 / 8(75.0)$ & 0.001 \\
\hline 7. Deep venous thrombosis prophylaxis & $15 / 19(78.9)$ & $1 / 8(12.5)$ & & 0.010 \\
\hline 8. Physiotherapy: Endurance exercise training & & $6 / 8(75.0)$ & $7 / 8(87.5)$ & 0.001 \\
\hline \multicolumn{5}{|c|}{$\begin{array}{l}\text { Content validity index }(\mathrm{CVI}) \text { : Proportion of experts scoring } 5 \text { or } 6 \text { for a specific indicator (score } \\
6 \text { means that the indicator is scored as highly relevant for follow-up); Consensus: CVI } \geq 75 \% \\
\text { obtained in round } 2 \text {; Italic means no consensus (CVI<75\% obtained in round } 2 \text { ) }\end{array}$} \\
\hline
\end{tabular}

\section{Discussion}

Consensus that an indicator is relevant for follow-up in studies on quality of in-hospital management of COPD exacerbation was reached by the overall Delphi panel for 26 of 72 process indicators $(36.1 \%)$ and 10 of 21 outcome indicators (47.6\%). Highest consensus levels were reached for the process indicators concerning oxygen therapy (100\%), patient education $(100 \%)$ and pulmonary rehabilitation $(100 \%)$ and for the outcome indicators regarding understanding of therapy (91.4-85.7\%) and self-management (88.6-88.2\%) (Table 2).

\section{Strengths and limitations}

Some methodological issues need to be addressed. Firstly, we used the Delphi technique, which is a structured facilitation technique that explores consensus among a group of experts by synthesizing opinions [29;32]. Several other consensus techniques exist, including consensus development conferences, the nominal group technique, the RAND appropriateness method and iterated consensus rating procedures [29].. The Delphi method was selected because it does not require face-to-face contact and therefore enables the 
anonymous inclusion of a large number of individuals across diverse locations and expertise [29]. Moreover, one of the key advantages of Delphi is that persuasive or prestigious experts cannot have undue influence on the opinions of others, as could happen in a face-to-face meeting of experts [33].

Secondly, selection procedure and composition of the expert panel need to be discussed. Delphi studies use individuals with known or demonstrable expertise in the subject being investigated [32;33]. Based on this principle, participants cannot be selected randomly. Instead, purposive sampling needs to be used, which implies that individuals are selected by an experienced investigator based on particular characteristics required of the sample members [46]. The sampling procedure resulted in 35 international experts from 15 developed countries, with 30 experts from Western Europe, one expert from Australia and finally four experts, respectively, from the United States. While 12 of 15 involved countries had a comparable representation of one participant ( $n=8$ countries) or two participants $(n=$ 3 countries) in the panel, two ountries (Belgium and the US) had four representatives. Finally, the UK was represented in the panel by a considerably higher number of 11 experts (including seven medical doctors, three nurses and one physiotherapist). The unequal representation of the countries and lack of representatives from other developed countries in the Delphi panel could have biased the results because of influence of cultural and economic features. However, since 2000, several worldwide established, rigorous evidence-based clinical practice guidelines (CPGs) have been developed for the assessment and management of patients with COPD [47]; for example, the guidelines of the GOLD (2009); the American Thoracic Society (ATS)-European Respiratory Society (ERS Task Force Celli \& Macnee (2004); and the NICE (2004) [1;35;36]. These CPGs are remarkably consistent and have very few areas of clinically relevant discrepancy [47]. Moreover, these guidelines, intended for worldwide use, are available free via the internet and provide for regular updating. Therefore, it is assumed that COPD experts out of developed countries are more or less familiar with these guidelines and the optimal management strategies addressed in the guidelines. In consequence, it is a reasonable assumption that lack or unequal representation of certain developed countries in the panel, although each with their own socio-demographic influences did not have major impact on Delphi results. Also important, no experts from continents like Africa, Asia and South America were included. However, we believe that non-representation of these continents in the Delphi panel would not have affected our results, as our primarily aim was to achieve knowledge for the developed healthcare systems. In conclusion, it is to believe that selected indicators and related management strategies are universal applicable in developed countries [48]. A third issue is the multidisciplinary character of the Delphi panel. This multidisciplinary approach is unique and favourable for validity and credibility of results, since COPD patients require specific 
multidisciplinary care, with medical doctors, nurses and physiotherapists being the prime actors in care for patients hospitalized with COPD exacerbation [49]. After Mann-Whitney test with Bonferroni correction, eight important differences between the disciplines were found, including differences between medical doctors, on the one hand and physiotherapists and nurses, on the other hand (Table 4). These eight indicators were 'non-medical' interventions like physiotherapy, rehabilitation, hydration and nutrition. These results confirm the need for inclusion of a multidisciplinary panel to rate multidisciplinary indicators. Also, these findings suggest that it is recommendable to also consider those indicators for which no overall consensus but consensus in one or two disciplines was obtained (Table 3).

We note that twice as many doctors were included in the Delphi panel in comparison to the nurses and physiotherapists (Table 1). On the one hand, this is justifiable as 39 of 72 scored process indicators $(54.2 \%)$ were strictly medical indicators. On the other hand, this unequal representation could have biased the overall results and the results per discipline. Firstly, as also indicated by the findings of our study (Table 3), it is evident that each panellist tends to rate higher for indicators related to their own discipline. In this study, the higher presentation of medical doctors may have biased the overall results in favour of the strictly medical indicators. In our study, 18 of 26 finally selected process indictors $(69.2 \%)$ were strictly medical indicators (Table 2). Although, this finding could also be explained by the fact that half of 72 process indicators $(54.2 \%)$ included in the Delphi questionnaire were indeed strictly medical indicators. Secondly, with regard to the results per discipline, medical doctors reached consensus for half as many process and outcome indicators (20-30\%) compared with nurses and physiotherapists $(55-60 \%)$ We believe that this finding can possibly be explained by the higher representation of medical doctors in the panel, since it is evident that the more persons are included, the fewer the likelihood that consensus will be reached [43]. A fourth methodological issue has to do with the identification of the indicators to build the Delphi questionnaire. It would have been interesting if we also considered the document of the ATS/ERS about outcomes for COPD pharmacological trials, as this provides a systematic overview of possible outcome measures [50]. Based on this document, outcomes as functional status, dyspnoea, frequency of exacerbation and topics regarding socioeconomic burden (i.e. use of healthcare resources, productivity losses and economic analysis) could also have been included in the questionnaire. The initial included outcome parameters could have been described in a more standardized way. Finally, response rates could be considered high and so favourable for validity of results, as they varied from $70 \%$ in round 1 to $88.6 \%$ in round 2 .

\section{Relevance of the set of process and outcome indicators}


Looking to the 26 process indicators for which consensus was reached by the overall Delphi panel, it turned out that these indicators refer to care activities that are suboptimally performed according to the literature regarding COPD management [10-12]; for example, referral to pulmonary rehabilitation, smoking cessation and patient education. Similarly, the selected outcome indicators refer to clinical outcomes that, according to outcome studies, are poor and show high variability across different hospitals; for example, readmission, mortality and quality of life. The high accordance between Delphi results and the literature suggests that the selected indicators have potential for improvement and therefore are relevant for follow-up when studying the impact of interventions implemented to improve performance on care processes and clinical outcomes concerning in-hospital management of COPD exacerbation [18].

\section{The European Quality of care pathways study on COPD exacerbation}

The European Pathway Association has launched the European Quality of Care Pathways (EQCP) study, a cluster randomized controlled trial, with the aim to measure the impact of care pathways on performance of care processes and clinical outcomes in patients hospitalized with an COPD exacerbation [51]. Care pathways aim to standardize care processes and to improve clinical outcomes [20;52]. In the EQCP study, process and outcome indicators will be followed up in organizations where a pathway was implemented compared with organizations where usual care is provided. The selected set of process and outcome indicators will be applied in this study [51].

\section{Conclusions}

By conducting the Delphi survey with 35 experts out of 15 countries, 26 process and 10 outcome indicators were selected as being relevant for follow-up of care provided to patients hospitalized with COPD exacerbation. The selected indicators refer to care activities and outcomes that, according to earlier studies, are poor and show high variability across different hospitals, which indicate that these indicators are sensitive for improvement. Therefore, researchers and clinicians who want to appropriately study quality of care and impact of care pathways for patients hospitalized with COPD exacerbation should primarily focus on these indicators. In addition, indicators should be embedded in daily clinical practice to encourage continuous quality assessment and improvement. Moreover, variance analysis Future randomized controlled trials are needed to address whether or not the selected indicators are really sensitive to change and furthermore to evaluate reliability and feasibility of the indicators. Also, when applying these indicators in a clinical practice setting, multidisciplinary decision-making by all stakeholders is recommended to decide which of 
these indicators should be followed up with regard to feasibility (data collection, time and man power) and interest of the involved stakeholders.

\section{Acknowledgements}

We gratefully thank all 35 experts who participated in the Delphi study: V. Barbier, P.J. Barnes, B. Boot, P.M.A. Calverley, G. Celis, D. Inal-Ince, M. Emtner, F. Froes, G.J. Gibson, C. Hall, G. Huchon, W. Janssens, R. Josa, P. Joud, M. Kelly, S. Lareau, P. Lindenauer, H. Lode, H.W. MacNee, T. McDonnell, T. McManus, G. Narsavage, G. S.I. Rennard, M. Roberts, R. Rodrı'guez-Roisin, M. Saetta, D. Schuermans, N.M. Siafkas, D.M. Smallwood, G. Smith, K. Suess, J. Williams, J. Williams, C. Zagers, J. Zielinski.

We acknowledge the supporting of the Clinical Research Fund of UZ Leuven, Belgium. We also acknowledge Pfizer Belgium, Pfizer Italy, Pfizer Ireland, and Pfizer Portugal, who supported this research by providing an unrestricted educational grant. The autonomy of EP-A and all involved academic institutions with regard to scientific independence and intellectual property on methodology is guaranteed 


\section{References}

1 Global Initiative for Chronic Obstructive Lung Disease: Global strategy for the diagnosis, management, and prevention of chronic obstructive pulmonary disease, updated 2007. [http://www.goldcopd.org/guidelines-global-strategy-for-diagnosis-management.html]

2 Halbert RJ, Natoli JL, Gano A, Badamgarav E, Buist AS, Mannino DM. Global burden of COPD: systematic review and meta-analysis. Eur Respir J 2006;28:523-532.

3 Mannino DM, Buist AS: Global burden of COPD: risk factors, prevalence, and future trends. Lancet 2007;370:765-773.

4 Chenna PR, Mannino DM. Outcomes of severe COPD exacerbations requiring hospitalization. Semin Respir Crit Care Med 2010;31:286-294.

5 Izquierdo JL, Barcina C, Jimenez J, Munoz M, Leal M. Study of the burden on patients with chronic obstructive pulmonary disease. Int J Clin Pract 2009;63:87-97.

6 Seemungal TA, Hurst JR, Wedzicha JA. Exacerbation rate, health status and mortality in COPD--a review of potential interventions. Int J Chron Obstruct Pulmon Dis 2009;4:203223.

7 Burge S, Wedzicha JA. COPD exacerbations: definitions and classifications. Eur Respir J Suppl 2003;41:46s-53s.

8 Cao Z, Ong KC, Eng P, Tan WC, Ng TP. Frequent hospital readmissions for acute exacerbation of COPD and their associated factors. Respirology 2006;11:188-195.

9 Garcia-Aymerich J, Farrero E, Felez MA, Izquierdo J, Marrades RM, Anto JM. Risk factors of readmission to hospital for a COPD exacerbation: a prospective study. Thorax 2003;58:100-105.

10 Decramer M, Bartsch P, Pauwels R, Yernault JC. Management of COPD according to guidelines. A national survey among Belgian physicians. Monaldi Arch Chest Dis 2003;59:62-80.

11 Hosker H, Anstey K, Lowe D, Pearson M, Roberts CM. Variability in the organisation and management of hospital care for COPD exacerbations in the UK. Respir Med 2007; 101:754-761.

12 Lodewijckx C, Sermeus W, Vanhaecht k, Panella M, Deneckere S, Leigheb F, Decramer M. Inhospital management of COPD exacerbations: a systematic review of the literature with regard to adherence to international guidelines. Journal of Evaluation in Clinical Practice 2009;15:1101-1110.

13 Almagro P, Barreiro B, Ochoa de EA, Quintana S, Rodriguez CM, Heredia JL, Garau J. Risk factors for hospital readmission in patients with chronic obstructive pulmonary disease. Respiration 2006;73:311-317. 
14 Bratzler DW, Oehlert WH, McAdams LM, Leon J, Jiang H, Piatt D. Management of acute exacerbations of chronic obstructive pulmonary disease in the elderly: physician practices in the community hospital setting. J Okla State Med Assoc 2004;97:227-232.

15 Groenewegen $\mathrm{KH}$, Schols AM, Wouters EF. Mortality and mortality-related factors after hospitalization for acute exacerbation of COPD. Chest 2003;124:459-467.

16 Agabiti N, Belleudi V, Davoli M, Forastiere F, Faustini A, Pistelli R, Fusco D, Perucci CA. Profiling hospital performance to monitor the quality of care: the case of COPD. Eur Respir J 2010;35:1031-1038.

17 Campbell H, Hotchkiss R, Bradshaw N, Porteous M. Integrated care pathways. BMJ 1998;316:133-137.

18 Panella M, Marchisio S, Di SF. Reducing clinical variations with clinical pathways: do pathways work? Int J Qual Health Care 2003;15:509-521.

19 Pearson SD, Goulart-Fisher D, Lee TH. Critical pathways as a strategy for improving care: problems and potential. Ann Intern Med 1995;123:941-948.

20 Vanhaecht K, De Witte K, Panella M, Sermeus W. Do pathways lead to better organised care processes? Journal of Evaluation in Clinical Practice 2009;15:782-788.

21 Vanhaecht K, De Witte K, Sermeus W. The impact of clinical pathways on the organisation of care processes. Leuven, ACCO, 2007.

22 Rotter T, Kinsman L, James E, Machotta A, Gothe H, Willis J, Snow P, Kugler J. Clinical pathways. effects on professional practice, patient outcomes, length of stay and hospital costs. Cochrane Database Syst Rev 2010;3:CD006632.

23 Sermeus W, De BL, Depreitere R, Dewaele K, Vanhaecht k, Vlayen J: An introduction to clinical pathways. In Devriese S, Lambert M, Eyssen M, Van de Sande S, Poelmans J, Van Brabandt H, Sermeus W, Vlayen J, Ramaekers D, (eds): The use of clinical pathways and guidelines to determine physicians' hospital fees prospectively: easier said than done.T. Brussels, Belgian Healthcare Knowledge Centre (KCE). KCE Reports, Volume 18A, 2005. [http:/www.kenniscentrum.fgov.be/nl/publicaties.html]

24 Van Herck P, Vanhaecht k, Sermeus W: Effects of Clinical Pathways: do they work? Journal of Integrated Care Pathways. Intl J Care Pathw 2004;8:95-105.

25 Vanhaecht K, Bollman M, Bower K, Gallagher C, Gardine A, Guezo J, Jansen U, Massoud R, Moody K, Sermeus W, Van Zelm R, Whittle C, Yazbeck A, Zander K, Massimilian P: Prevalence and use of clinal pathways in 23 countries - an internation survey by the European Pathway Association(www.E-P-A-.org. Intl J Care Pathw 2006;10:28-34.

26 Lodewijckx C, Sermeus W, Vanhaecht k, Panella M, Deneckere S, Leigheb F, Decramer M: Impact of care pathways for in-hospital management of COPD exacerbations: a systematic review. Int J Nurs Stud. 2011; 48:1445-56. 
27 Campbell NC, Murray E, Darbyshire J, Emery J, Farmer A, Griffiths F, Guthrie B, Lester $\mathrm{H}$, Wilson $\mathrm{P}$, Kinmonth $\mathrm{AL}$. Designing and evaluating complex interventions to improve health care. BMJ 2007;334:455-459.

28 Craig P, Dieppe P, Macintyre S, Michie S, Nazareth I, Petticrew M. Developing and evaluating complex interventions: the new Medical Research Council guidance. BMJ 2008;337:a1655.

29 Campbell SM, Braspenning J, Hutchinson A, Marshall MN. Research methods used in developing and applying quality indicators in primary care. BMJ 2003;326:816-819.

30 Mainz J. Defining and classifying clinical indicators for quality improvement. Int J Qual Health Care 2003;15:523-530.

31 Rubin HR, Pronovost P, Diette GB. From a process of care to a measure: the development and testing of a quality indicator. Int J Qual Health Care 2001;13:489-496.

32 Hasson F, Keeney S, McKenna H. Research guidelines for the Delphi survey technique. J Adv Nurs 2000;32:1008-1015.

33 Keeney S, Hasson F, McKenna H. Consulting the oracle: ten lessons from using the Delphi technique in nursing research. J Adv Nurs 2006;53:205-212.

34 Siafkas N, Wedzicha J. Management of acute exacerbation of chronic obstructive pulmonary disease. In Siafkas N, (ed): Management of chronic obstructive pulmonary disease.European Respiratory Monograph. Sheffield, European Respiratory Society Ltd, 2006, vol 11, pp 387-400.

35 Celli BR, Macnee W. Standards for the diagnosis and treatment of patients with COPD: a summary of the ATS/ERS position paper. Eur Respir J 2004;23:932-946.

36 National Institute for Clinical Excellence (NICE). Chronic obstructive pulmonary disease: national clinical guideline for management of chronic obstructive pulmonary disease in adults in primary and secondary care. Thorax 2004;59:1-53.

37 Rodriguez-Roisin R. COPD exacerbations.5: management. Thorax 2006;61:535-544.

38 Gudmundsson G, Gislason T, Janson C, Lindberg E, Hallin R, Ulrik CS, Brondum E, Nieminen MM, Aine T, Bakke P. Risk factors for rehospitalisation in COPD: role of health status, anxiety and depression. Eur Respir J 2005;26:414-419.

39 Roberts CM, Barnes S, Lowe D, Pearson MG. Evidence for a link between mortality in acute COPD and hospital type and resources. Thorax 2003;58:947-949.

40 Seemungal TA, Donaldson GC, Paul EA, Bestall JC, Jeffries DJ, Wedzicha JA. Effect of exacerbation on quality of life in patients with chronic obstructive pulmonary disease. Am J Respir Crit Care Med 1998;157:1418-1422.

41 Wang $Q$, Bourbeau J. Outcomes and health-related quality of life following hospitalization for an acute exacerbation of COPD. Respirology 2005;10:334-340. 
42 Yohannes AM, Baldwin RC, Connolly MJ. Predictors of 1-year mortality in patients discharged from hospital following acute exacerbation of chronic obstructive pulmonary disease. Age Ageing 2005;34:491-496.

43 Polit DF, Beck CT. The content validity index: are you sure you know what's being reported? Critique and recommendations. Res Nurs Health 2006;29:489-497.

44 Wynd CA, Schmidt B, Schaefer MA. Two quantitative approaches for estimating content validity. West J Nurs Res 2003;25:508-518.

45 McKenna HP. The Delphi technique: a worthwhile research approach for nursing? J Adv Nurs 1994;19:1221-1225.

46 Trochim W. Non probability sampling. In Research Methods Knowledge Base (Trochim W, ed.), Cornell University Cornell University, 2006.

[http://www.socialresearchmethods.net/kb/external.php]

47 Pierson DJ. Clinical practice guidelines for chronic obstructive pulmonary disease: a review and comparison of current resources. Respir Care 2006;51:277-288.

48 Marshall MN, Shekelle PG, McGlynn EA, Campbell S, Brook RH, Roland MO. Can health care quality indicators be transferred between countries? Qual Saf Health Care 2003;12:8-12.

49 Kuzma AM, Meli Y, Meldrum C, Jellen P, Butler-Lebair M, Koczen-Doyle D, Rising P, Stavrolakes K, Brogan F. Multidisciplinary care of the patient with chronic obstructive pulmonary disease. Proc Am Thorac Soc 2008;5:567-571.

50 Cazzola M, Macnee W, Martinez FJ, Rabe KF, Franciosi LG, Barnes PJ, Brusasco V, Burge PS, Calverley PM, Celli BR, Jones PW, Mahler DA, Make B, Miravitlles M, Page CP, Palange P, Parr D, Pistolesi M, Rennard SI, Rutten-van Molken MP, Stockley R, Sullivan SD, Wedzicha JA, Wouters EF. Outcomes for COPD pharmacological trials: from lung function to biomarkers. Eur Respir J 2008;31:416-469.

51 Vanhaecht K, Sermeus W, Peers J, Lodewijckx C, Deneckere S, Leigheb F, Decramer M, Panella M. The impact of care pathways for exacerbation of Chronic Obstructive Pulmonary Disease: rationale and design of a cluster randomized controlled trial. Trials 2010;11:111.

52 Vanhaecht K, De Witte K, Sermeus W. The Care Process Organisation Triangle: A framework to better understand how clinical pathways work. Intl J Care Pathw 2007;11:1-8. 
Appendix 1: The Delphi questionnaire

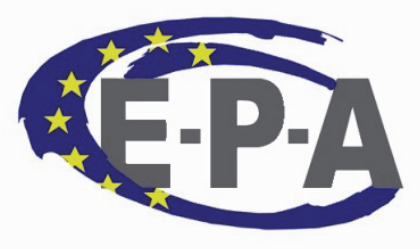

EUROPEAN

PATHWAY

ASSOCIATION

WWW.E-P-A.org

\title{
EQCP-PROJECT
}

EUROPEAN QUALITY OF CARE PATHWAYS

\section{INTERNATIONAL EXPERT PANEL QUESTIONNAIRE ROUND 1}

\author{
European Pathway Association (www.E-P-A.org) \\ Center for Health Services and Nursing Research, \\ Faculty of Medicine, Katholieke Universiteit Leuven, Belgium \\ School of Public Health, Faculty of Medicine, \\ Amedeo Avogadro University of Eastern Piemont, Italy
}

\section{Address of correspondence:}

\section{cathy.lodewijckx@uzleuven.be}

Kris Vanhaecht, RN, $\mathrm{PhD}^{\star \wedge}$, Walter Sermeus, RN, $\mathrm{PhD}^{\star \wedge}$, Jan Peers, MD, $\mathrm{PhD}^{\circ}$, Svin Deneckere, RN, MSc, PhD Cand^, Fabrizio Leigheb, MD, PhD Cand", Cathy Lodewijckx, RN, MSc, $\mathrm{PhD}$ Cand $^{\wedge}$, Marc Decramer, MD, $\mathrm{PhD}^{\wedge}$ and Massimiliano Panella, MD, PhD*” 


\section{IMPORTANT TO READ BEFORE FILLING IN THE QUESTIONNAIRE}

Care pathways, also known as clinical pathways or critical pathways, are used worldwide for a variety of patient groups to lower unwanted variation and standardize care based on the latest evidence. Nonetheless very few strong prospective studies have been performed and published on the impact of pathways on quality and efficiency of care. The goal of the European Quality of Care Pathways (EQCP) study is to evaluate the effectiveness of a care pathway for patients with an acute exacerbation of Chronic Obstructive Pulmonary Disease (COPD) in acute hospitals and the immediate link with primary care. Inclusion criteria on patient level are: patients admitted with an acute exacerbation of COPD; an ASA-score of 2 or 3 (patient with mild or systemic disease that is not in constant threath of life). Exclusion criteria on patient level are: admission required to intensive care unit; need for Non Invasive Positive Pressure Ventilation (NIPVV) or Invasive Positive Pressure Ventilation (IPVV); cognitive impairment; and expected not to be discharged at home.

To evaluate the impact of the care pathway, the adherence to key interventions and the obtained clinical outcomes will be compared between an experimental and control group through a cluster randomized controlled trial. The project will be conducted in several European countries.

As it is not feasible to follow up all possible interventions and outcomes published in literature, we would like your expert opinion and assistance in selecting these key interventions and outcome indicators to follow up in our study. Regarding the variance in management of a COPD exacerbation worldwide, we want to consult a multidisciplinary and multinational panel of experts to guarantee that our research results can be generalised to a broad population and are relevant for international clinical practice. 
The questionnaire is built up in three parts:

\section{Part l: Selection of key interventions for follow-up}

Based on the GOLD guideline (Global Strategy for Diagnosis, Management, and Prevention of COPD) (appendix 1), a list of interventions for the management of a COPD exacerbation was defined. We would like you to indicate, on a 6-point rating scale, which impact you believe that the listed key interventions have on clinical outcomes in patients with a COPD exacerbation. The interventions with highest impact on outcomes, according to the international expert panel, will be selected for follow-up in our study.

\section{Part II: Selection of clinical outcome indicators}

Based on literature review a selection of outcome indicators was defined. We would like you to indicate, on a 6-point rating scale, how sensitive for change you believe the listed outcome indicators would be when implementing an evidence based care pathway for patients with a COPD exacerbation. The indicators which are most sensitive for change, according to the international expert panel, will be selected for follow-up in our study.

\section{Part III: Demographic information}

In this part we would like you to fill in some general information to describe our expert panel.

This questionnaire will be answered by a selected group of experts on COPD on an international level. We would like you to return the answered questionnaire to cathy.lodewijckx@uzleuven.be by October 24th. Completion of the survey has to be done electronically by marking and filling in the grey boxes below and will take you about twenty minutes. In a second round you will receive feedback on the group results compared with your own results. In addition you will have the possibility to adjust your answers based on the group responses. Anonymity is guaranteed.

We would like to thank you in advance for your effort in helping us with our project. Please do not hesitate to contact us if you have questions about the project. 


\section{PART I: KEY INTERVENTIONS IN THE HOSPITAL MANAGEMENT OF A COPD EXACERBATION}

Please indicate on a 6-point rating scale, which impact you believe that the following key interventions have on clinical outcomes in patients with an exacerbation of COPD. For example:

Low impact on outcomes High impact on outcomes

$\begin{array}{lcccccc}\text { Key intervention } X & 1 & 2 & 3 & 4 & 5 & 6 \\ & \square & \square & \square & \square & \square & \square\end{array}$

If you mark 6, this would mean that you believe that key intervention $X$ has a high impact on clinical outcomes and therefore should be followed up in the study.

\section{Low impact on outcomes}

123
High impact on outcomes

$\begin{array}{lll}4 & 5 & 6\end{array}$

1. Medical history before exacerbation:
a. Spirometric classification of severity
b. Documenting frequency and severity of attacks of breathlessness
c. Documenting frequency and severity of chronic cough
d. History of chronic sputum production
e. Documenting possible limitation of daily activities

f. Prior arterial blood gas measurements in stable condition

g. Number of previous exacerbations in the previous year

h. Pre-existing co-morbidities

i. Cardiovascular status

j. Screening for diabetes

k. Present treatment regimen

I. Smoking status

2. Assessment of symptoms

Definition: changes in baseline dyspnoe, cough and sputum production

3. Physical examination

Definition: inspection, palpation and percussion, and auscultation 
Low impact on outcomes

4. Assessment of co-morbidities

5. Monitoring of fluid balance

6. Body mass index (BMI)

7. Temperature

8. Pulse rate

9. Blood pressure

10. Pulse oximetry

a. At admission

b. Prior to discharge in patients hypoxemic during a COPD exacerbation

c. In the following three months in patients hypoxemic during a COPD exacerbation

d. After discharge in patients with Long-Term

Oxygen Therapy (LTOT)
High impact on outcomes

$\begin{array}{llllll}1 & 2 & 3 & 4 & 5 & 6\end{array}$

$\square \quad \square \quad \square \quad \square \quad \square \quad \square$

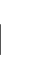


17. Pulmonary testing after discharge

$\begin{array}{llllll}1 & 2 & 3 & 4 & 5 & 6\end{array}$
f. Spirometry
g. Residual volume
h. Lung diffusion testing
i. Bronchodilator reversibility testing
j. Total Lung Capacity (TLC)

18. Identification for pulmonary rehabilitation

19. Identification for lung volume reduction surgery

20. CT THORAX: $1 X$ year

21. ECHO CARDIO: $1 \mathrm{X}$ year

22. Appropriate prescription of short-acting bronchodilatators

23. Appropriate prescription of long-acting bronchodilatators ( $\beta$-agonists and/or anticholinergics)

24. Appropriate prescription of glucocorticosteroids: oral or intravenous

25. Appropriate prescription of methylxanthines (theophylline or aminophylline) Indication: inadequate or insufficient respons to short-acting bronchodilators

26. Antibiotics in patients if indicated Indication:

- Patients with 1) increased dyspnoe, 2) increased sputum volume and 3) increased sputum purulence OR

- Patients with 1) increased sputum purulence, 2) increased sputum volume or increased dyspnoe, 3) need for mechanical ventilation

27. Controlled oxygen therapy in hypoxemic patients

28. Initiation of long-term oxygen therapy (LTOT) if the patient remains hypoxemic

29. Assessment and management of social situation (i.e. living status, visiting nurse, meal provisions, etc.)

30. Fluid administration in dehydrated patients

31. Supplementary nutrition in patients with BMI $<20$ 
Low impact on outcomes

12

32. Deep venous thrombosis prophylaxis

Definition: mechanical devices, heparins, etc.

33. Smoking cessation advice when active smoker

34. Patient Education:

a. Information about the nature of COPD

b. Instruction on how to use inhalers and other treatments

c. Information about oxygen treatment

b. Information about recognition and treatment of exacerbations

C. Strategies for minimizing dyspnoe

35. Physiotherapy:

a. Chest physiotherapy for breathing and sputum clearance when increased sputum volume and/or impaired mucus transport

b. Endurance exercise training

c. Resistance training to improve skeletal muscle strength

d. Activities of Daily Life l.e.: walking stairs, cooking diner, dressing, going outside, cleaning, ...

36. Referral to dietician in patient with obesity or cachexie

37. Referral to pulmonary rehabilitation

38. Treatment of co-morbid conditions l.e.: heart failure, arrhythmias, etc.

39. Assessment of differential diagnosis

Definition: Re-evaluation of other medical conditions that can aggravate symptoms or mimic COPD exacerbations when patients with apparent exacerbation do not respond to treatment (i.e. pneumonia, congestive heart failure, pneumothorax, pleural effusion, pulmonary embolism and cardiac arrhythmia).

\section{OTHER SUGGESTIONS ON KEY INTERVENTIONS:}




\section{PART II: OUTCOME INDICATORS}

Please indicate on a 6-point rating scale how sensitive for change you believe the listed outcome indicators would be when implementing a care pathway for patient hospitalized with an exacerbation of COPD.

For example:

Low sensitive for change High sensitive for change

Outcome indicator $X$

$\begin{array}{cccccc}1 & 2 & 3 & 4 & 5 & 6 \\ \square & \square & \square & \square & \square & \bigotimes\end{array}$

If you mark 6 , this would mean that you believe that outcome indicator $X$ will be very sensitive for change when implementing a care pathway for patient hospitalized with an exacerbation of COPD and therefore should be followed up in the study.

\section{Outcome indicators AT discharge}

Low sensitive for change

12

1. Inhaled $\beta$-agonist therapy is required no more frequently than every 4 hours

2. Patient, if previously ambulatory, is able to cope with basic needs in his/her situation

3. Patient is able to eat and sleep without frequent awakening by dyspnea

4. Patient has been clinically stable for 12-24 hours

5. Last measure of arterial blood gases were acceptable according to condition of the patient

6. Patient and/or home caregiver fully understands correct use of therapy:
a. Oral medication therapy
b.
Inhaler therapy
c.
Oxygen therapy if LTOT

7. Patient and/or home caregiver fully understands correct use of inhaler

8. Patient, family and physician are confident that the patient can manage successfully at home

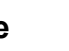

\section{High sensitive for change}

$\begin{array}{lllll}3 & 4 & 5 & 6\end{array}$

$\square$



9. Ability to cope in usual environment
1

23
45
6
10. Forced Expiratory Volume in one second $\left(\mathrm{FEV}_{1}\right)$
11. Forced Vital Capacity (FVC)
12. Inspiratory capacity
13. 6 minute walking distance
14. Symptoms at rest and during exercise
15. Length of stay (LOS)
16. Quality of sleep

\section{Outcome indicators AFTER discharge}

Low sensitive for change

$$
12
$$

17. Interval before next admission

18. Health Related Quality of Life (HRQL)

19. Patients' perception of coordination between hospital and home health care

20. Patient satisfaction with therapie and care

21. Mortality within 1 year after exacerbation
High sensitive for change

$\begin{array}{lll}4 & 5 & 6\end{array}$

\section{OTHER SUGGESTIONS ON OUTCOME INDICATORS:}




\section{PART III: DEMOGRAPHIC INFORMATION}

1. City and Country in which you are currently working:

2. Name of your hospital / organization:

3. Type of hospital:

$\square \quad$ Academic hospital

$\square \quad$ Community teaching hospital

$\square \quad$ Community hospital

$\square$ Other:

4. Number of beds in your organization: beds

5. Professional group:

Medical doctor

Nurse

$\square \quad$ Physiotherapist

6. Years of experience in respiratory care: years

7. Age:

$\square$ 20-29 $\square$ 30-39 $\square$ 40-49 $\square$ 50-59 $\square$ 60-69 $\square>70$

8. Sex:
Male
Female

9. Date you completed the questionnaire: / / 


\section{Chapter 5:}

How to build the clinical content of an evidence-based care pathway for COPD exacerbation

This chapter was submitted for publication in 2012 as: How to build the clinical content of an evidence-based care pathway for COPD exacerbation. Lodewijckx C, Decramer M, Sermeus W, Panella S, Deneckere S, Vanhaecht K. 


\begin{abstract}
Background: Optimisation of the clinical care process by integration of evidence-based knowledge is one of the active components in care pathways. When studying the impact of a care pathway by using a cluster-randomised design, standardisation of the care pathway intervention is crucial.
\end{abstract}

Objective: To develop the clinical content of an evidence-based care pathway for in-hospital management of COPD exacerbations in the context of a cluster-randomised controlled trial (cRCT) on care pathway effectiveness.

Methods: The clinical content of the COPD care pathway was developed using an eight-step method, following recognized process design and guideline development methods.

Results: The development strategy resulted in a set of 38 key interventions for in-hospital management of COPD exacerbations, and a set of 24 process and 15 outcome indicators. Nine Belgian multidisciplinary teams piloted both the key interventions and indicators. The key intervention set was judged by the teams as being valid and clinically applicable. The pilot study determined that the measurements on the indicators were feasible for the involved clinicians and patients.

Conclusions: The set of 38 key interventions and the set of process and outcome indicators were found to be appropriate for the development and standardisation of the clinical content of the COPD care pathway in the context of a CRCT on pathway effectiveness. The newly developed eight-step method may facilitate multidisciplinary teams who care for other patient populations in designing the clinical content of their own proposed care pathways. 


\section{Background}

Standardisation of the clinical care process through integration of evidence-based knowledge has proven to be an effective strategy for reducing unwanted variations in treatment and for minimising the probability of medical errors [1]. However, major difficulties arise when introducing evidence and clinical guidelines into routine daily practice, and many patients, as a result, do not receive appropriate care, or receive unnecessary or harmful care [2-5].

A possible tool to facilitate implementation of evidence into practice is a care pathway. Care pathways are complex interventions for mutual decision making, organisation, and standardisation of predictable care for a well-defined group of patients during a well-defined period [6-8]. One of the active ingredients in care pathways is the integration of a set of evidence-based key interventions [8;9].

Care pathways induce change at different levels of the organisation (i.e. patient, team, hospital); consequently, variability at individual level outcomes may reflect the impact of higher-level complexity processes. To deal with these multilevel effects, cluster randomised designs should be used when studying the impact of care pathways [10;11]. Importantly, in cluster randomised controlled trials (cRCTs) the care pathway under evaluation is implemented at different sites. Consequently, a challenge within CRCT designs is to standardise the intervention in order to deliver the 'same' intervention at the different sites under study [10;12-14]. Standardisation in complex interventions refers to adaptation of the care pathway components to the context level, without compromising the integrity of the intervention being evaluated across multiple sites [10;14;15].

In 2009, the European Pathway Association (E-P-A) launched the European Quality of Care Pathways (EQCP) study, an international CRCT addressing the impact of a care pathway for chronic obstructive pulmonary disease (COPD) exacerbations [9]. In the context of the EQCP study, the evidence-based clinical content of a care pathway for COPD exacerbations needed to be developed, including a set of evidence-based key interventions and a set of process and outcome indicators, which could be implemented at the different experimental sites.

This paper describes the development of the clinical content of a care pathway for inhospital management of COPD exacerbations.

\section{Methods}

The method for developing the evidence-based clinical content of the COPD care pathway included eight different steps (Figure 1). The applied method is based on the process design methodology developed by Berry et al. [16], and the guideline development methods of the American College of Chest Physicians (ACCP) [17], the World Health Organization (WHO) 
[18], and the Healthcare Infection Control Practices Advisory Committee (HICPAC) [19].

Figure 1. Eight-step method for clinical content development of an evidence-based care pathway for COPD exacerbation

\begin{tabular}{|l|l|}
\hline $\begin{array}{l}\text { 1. Specification of the care population \& } \\
\text { composition of an expert panel }\end{array}$ & $\begin{array}{l}- \text { Population: patients hospitalised with COPD } \\
\text { exacerbation }\end{array}$ \\
$\begin{array}{l}\text { Panel: Pulmonologist, physiotherapist, clinical } \\
\text { nurse specialist, epidemiologist, two experts in } \\
\text { patient care management }\end{array}$ \\
\hline
\end{tabular}

\begin{tabular}{|l|l|l|l}
\hline $\begin{array}{l}\text { 2. Literature review \& identification of } \\
\text { clinical activities and outcomes }\end{array}$ & $\longrightarrow \begin{array}{l}\text { - Selected literature: guidelines }(n=3) \text {; care maps } \\
(n=2) ; \text { reviews }(n=3) \\
\text { - Identified clinical activities: } n=58 \\
\text { - Identified outcomes: } n=34\end{array}$ \\
\hline
\end{tabular}

\begin{tabular}{|l|l|}
\hline $\begin{array}{l}\text { 3. International Delphi study: Rating of } \\
\text { content validity }\end{array} \quad \begin{array}{l}\text { Process indicators with content validity }>75 \% \text { : } \\
\mathrm{n}=21 / 72(36.1 \%) \\
\text { Outcome indicators with content validity }>75 \% \text { : } \\
\mathrm{n}=10 / 21(47.6 \%)\end{array}$ \\
\cline { 2 - 3 }
\end{tabular}

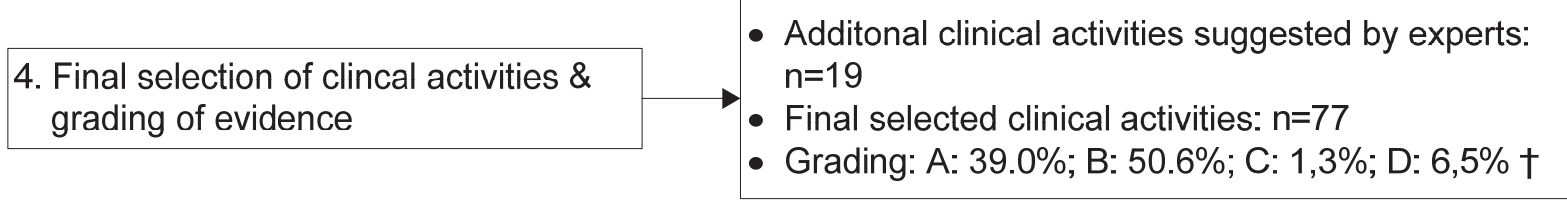

\begin{tabular}{|l|l|}
\hline $\begin{array}{l}\text { 5. Process flow chart: Categorisation of } \\
\text { clinical activities into key interventions } \\
+ \text { subcomponents }\end{array}$ & $\rightarrow \begin{array}{l}\text { - } 77 \text { clinical activities }=>38 \text { key interventions }+ \\
\text { subcomponents } \\
\text { - Process flow chart: } 3 \text { core processes }\end{array}$ \\
\hline
\end{tabular}
6. Detailed description of each key intervention: rationale, description, references and grading
- Manual with process flow chart and 38 detailed key interventions

7. Translation into a set of proces and outcome indicators

- Set of indicators: $\mathrm{n}=24$ process and 20 outcome indicators

- Baseline measures: $\mathrm{n}=23$ baseline variables
8. Piloting by multidisciplinary teams in different organisations
- Piloting by nine in-hospital multidisciplinary COPD teams

\section{† Scottish Intercollegiate Guidelines Network (SIGN) grading system [20]}

1++ High-quality meta-analyses, systematic reviews of RCTs, or RCTs with a very low risk of bias

1+ Well-conducted meta-analyses, systematic reviews, or RCTs with a low risk of bias

1- Meta-analyses, systematic reviews, or RCTs with a high risk of bias

2++ High-quality systematic reviews of case control or cohort or studies High-quality case control or cohort studies with a very low risk of confounding or bias and a high probability that the relationship is causal

$2^{+}$Well-conducted case control or cohort studies with a low risk of confounding or bias and a 
moderate probability that the relationship is causal

2- Case control or cohort studies with a high risk of confounding or bias and a significant risk that the relationship is not causal

3 Non-analytic studies, e.g. case reports, case series

4 Expert opinion

A At least one meta-analysis, systematic review, or RCT rated as $1++$, and directly applicable to the target population; or a body of evidence consisting principally of studies rated as $1+$, and directly applicable to the target population and demonstrating overall consistency of results

B A body of evidence including studies rated as 2++, directly applicable to the target population and demonstrating overall consistency of results

C A body of evidence including studies rated as $2+$, and directly applicable to the target population and demonstrating overall consistency of results; or extrapolated evidence from studies rated as $2++$

D Evidence level 3 or 4 ; or extrapolated evidence from studies rated as $2+$

\section{Results}

A set of 38 evidence-based key interventions (Appendix 1) and a set of 24 process and 15 outcome indicators (Table 3 ) were developed in eight different steps. In the following section, descriptions and rationale for each development step are presented.

Step 1: Specification of the care population and selection of an expert panel [8;18;19;21;22]

The patient population under study was specified as 'Patients hospitalised with COPD exacerbation'. To ensure clinical validity and feasibility of the end product, an expert panel was involved in each step of the development method. This panel was composed of the following: (i) three clinicians with internationally recognised clinical and scientific expertise in COPD exacerbations: a pulmonologist (MD), who is also president of the European Respiratory Society; a physiotherapist (TT), who specialises in pulmonary rehabilitation, and a clinical nurse specialist in COPD (CL); (ii) an epidemiologist (MP), who specialises in organisation of primary and secondary chronic care; and (iii) two professors (WS, KV) in patient care management, who have extensive clinical and scientific expertise in development and implementation of care pathways. All six experts had extensive research experience.

\section{Step 2: Literature review and extraction of clinical activities and outcomes [23]}

An extensive literature review was conducted by the main researchers, CL and KV (Figure 2). Firstly, an initial literature search was carried out in April 2008 in the context of the Delphi study, and an updated search was performed in June 2011. In the following section, the updated search is described. The following resources were explored: (I) websites of 
international respiratory societies: American Thoracic Society (ATS) (www.thoracic.org); British Thoracic Society (BTS) (www.brit-thoracic.org.uk); European Respiratory Society (ERS) (www.ersnet.org); Global Strategy for Diagnosis, Management, and Prevention of COPD (GOLD) (www.goldcopd.org); National Institute for Health and Clinical Excellence (NICE) (www.nice.org.uk); Scottish Intercollegiate Guidelines Network (SIGN) (www.sign.ac.uk); (II) Public resources for evidence-based clinical practice guidelines (www. guideline.gov, www.g-i-n.net); (III) electronic databases including Medline and Embase and Cochrane; (IV) available process flow diagrams founded on evidence-based medicine (www.mapofmedicine.com, http://group.bmj.com/products/evidence-centre.com).

For guidelines developed by international societies, only those guidelines were considered that were updated within the last five years. For Pubmed and Cochrane, we used the MeSH terms 'COPD' combined with (i) 'practice guideline', (ii) 'disease exacerbation and patient care management', and (iii) 'outcomes'. For Embase, we used the MeSH terms 'chronic obstructive lung disease' combined with (i) 'practice guideline' and (ii) 'disease exacerbation and patient care', and (iii) 'outcomes'. Non-MeSH terms used in Embase were 'COPD' in combination with 'exacerbation and management'. Search limit parameters included: (i) [dp], published between 2005 and 2011, and (ii) [lang], written in English, French, German, Italian, or Dutch.

Secondly, we performed a two-phase screening evaluation of publications selected from websites of the respiratory societies, Map of Medicine, and the electronic databases. In the first phase, publications were scrutinised for relevance based on appropriateness of the title and abstract. If relevance was unclear, or if the abstract was unavailable, the publication was included for further appraisal of the full text for relevance. In the second phase, two independent researchers $(\mathrm{CL}$ and $\mathrm{KV}$ ) reviewed the full text of the selected guidelines, reviews, or process flow diagrams. The following inclusion criteria were used: (i) reportage of clinical processes and outcomes regarding in-hospital management of COPD exacerbation; (ii) evidence was reported in terms of guidelines, process flow diagrams, reviews, or overview papers; (iv) published between 2005 and 2011; (v) published in English, French, German, Italian, or Dutch; and (vi) quality of underlying evidence can be appraised by in-text references. The literature research revealed initially three guidelines, one process-flow diagram, and 2939 digital records from the electronic medical databases (Figure 2). After exclusion of irrelevant publications ( $n=2851$ ), we included for development of the evidencebased clinical content of the care pathway three guidelines, two process flow diagrams, and 37 reviews [5;5;24-57]. 
Figure 2. Flow diagram of literature search strategy and numbers of identified candidate articles at each step

- Guidelines identified through websites of international respiratory societies: $n=3$

- Process flow diagrams identified through Map of Medicine (MOM) and BMJ Best Practice: $n=2$

- Reviews identified through electronic database searching: $n=2939$

Medline: $n=739$

Embase: $n=2031$

Cochrane: $n=169$

Screening on title and abstract/short description

Full text articles independently assessed for eligibility by two reviewers (CL \& KV):

Guidelines: $n=3$

Process flow diagram: $n=2$

Electronic records: $n=88$

Selected for development of the clinical content:

Guidelines: $n=3$

Process flow diagram: $n=2$

Electronic records: $n=37$ 
Finally, the selected literature was thoroughly screened for identification of all possible clinical activities and outcomes related to in-hospital management of COPD exacerbations. The detected clinical activities were extracted and listed, and the corresponding literature sources were recorded. In total, 58 different clinical activities were extracted from the selected literature (Table 1, no. 1-58). Besides these, 34 outcome categories were identified (Table 2).

Table 1. Identified clinical activities for in-hospital management of COPD exacerbations

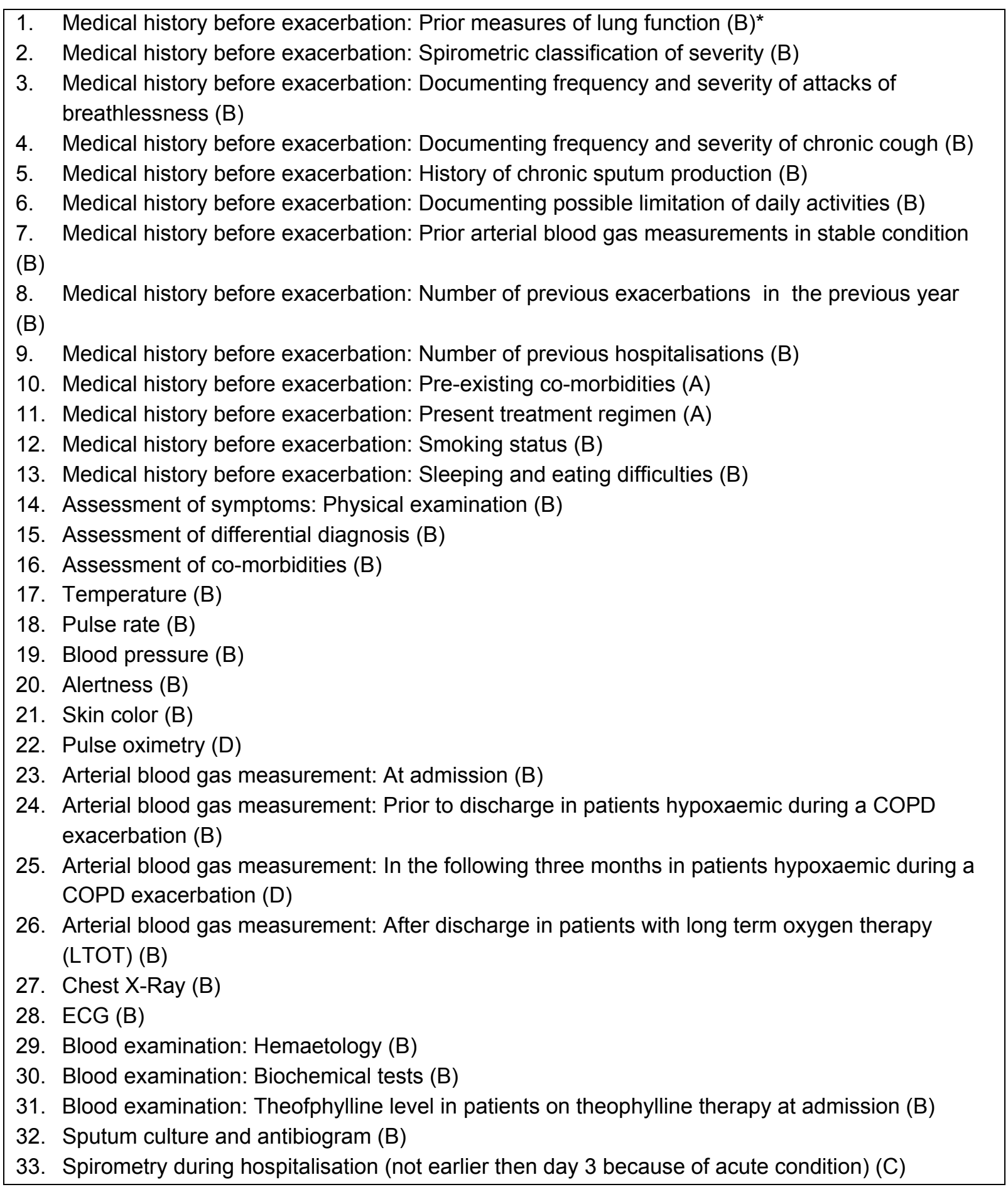


34. Admission of ICU if exacerbation is life treathening (B)

35. Appropriate prescription of short-acting bronchodilatators $(A)$

36. Appropriate prescription of long-acting bronchodilatators ( $\beta$-agonists and/or anticholinergics) (A)

37. Appropriate prescription of inhaled corticosteroids (A)

38. Appropriate prescription of glucocorticosteroids: oral or intravenous $(A)$

39. Appropriate prescription of methylxanthines (theophylline or aminophylline) $(A)$

40. Antibiotics in patients if indicated $(A)$

41. Controlled oxygen therapy in hypoxemic patients $(A)$

42. Assisted ventilation if necessary (A)

43. Smoking cessation advice when active smoker (A)

44. Patient Education Information about recognition and treatment of exacerbation (A)

45. Patient Education: Instruction on how to use inhalers $(A)$

46. Chest physiotherapy: sputum clearance $(A)$

47. Referral to pulmonary rehabilitation (A)

48. Monitoring of fluid balance (A)

49. Fluid administration in dehydrated patients $(A)$

50. Supplementary nutrition in patients with $\mathrm{BMI}<20$ (B)

51. Screening and update of vaccination status (B)

52. Deep venous thrombosis prophylaxis $(A)$

53. Treatment of co-morbid conditions $(A)$

54. Initiation of long-term oxygen therapy (LTOT) if the patient remains hypoxemic (A)

55. Assessment of medical discharge criteria (D)

56. Assessment and management of home situation (A)

57. Oral information and discharge letter regarding predyspnscribed home therapy and follow-up appointment (B)

58. Arrangement of follow-up appointment 4-6 weeks after discharge (D)

59. Medical history before exacerbation: Number of previous admissions to ICU (D)

60. Medical history before exacerbation: Cardiovascular status (B)

61. Glucose monitoring (B)

62. CT THORAX: $1 X$ year $(B)$

63. ECHO CARDIO: $1 \mathrm{X}$ year $(\mathrm{B})$

64. Patient Education: nformation about the nature of COPD (A)

65. Patient education: Self-management plan (A)

66. Patient Education Strategies for minimising dyspnoea $(A)$

67. Patient Education Information about oxygen treatment $(A)$

68. Physiotherapy: Breathing techniques (A)

69. Physiotherapy: Activities of Daily Life (A)

70. Physiotherapy: Positioning (A)

71. Identification for pulmonary rehabilitation determinant $(B)$

72. Body mass index (BMI) determinant (A)

73. Screening for weight loss $(A)$

74. Referral to dietician in patient with obesity or cachexie (B)

75. Assessment and management of anxiety and depression (B)

76. Information letter for general practitioner (B)

77. Discharge checklist (B)

*SIGN grading system (see explanation in Figure 1) [20] 
Table 2. Identified outcomes for in-hospital management of COPD exacerbations

- Readmission: 30-day, 3-month, 6-month, 1year

- Number of hospital admissions

- Interval before next admission

- Frequency and severity of exacerbation

- Mortality: In-hospital, 30-day, 3-month, 6month, 1-year

- Survival: 1-year

- Length of stay (LOS)

- Level of understanding of inhaler therapy

- Compliance with home oxygen therapy

- Performance of physical exercise

- Smoking status: 30-day, 3-month, 6 month, 1year

- Symptoms of anxiety and depression

- Health-related quality of life (HRQL): symptoms, disability, morbidity and quality of life; psychological well being)

- Health status

- Quality-adjusted life expectancy measure (QALY) and disability adjusted life years (DALY)

- Functional capacity

- Exercise capacity

- Physical performance: 6-Minute walking distance (6-MWD), 20-MWD, Shuttle walk test, maximum workload, treadmill time, maximum oxygen uptake, quadriceps strength, hand grip force, maximal inspiratory mouth pressure

- Severity of breathlessness: dyspnoea, symptoms at rest and during exercise
- Inhaled $\beta$-agonist therapy is required no more frequently than every 4 hours

- Patient, if previously ambulatory, is able to cope with basic needs in his/her situation, in usual environment

- Patient is able to eat and sleep without frequent awakening by dyspnoea

- Patient has been clinically stable for 12-24 hours

- Last measure of arterial blood gases (ABGs) were acceptable according to condition of the patient

- Patient and/or home caregiver fully understands correct use of therapy: oral medication therapy, inhaler therapy, oxygen therapy if home oxygen therapy

- Patient, family, and physician are confident that the patient can manage successfully

- Lung function parameters: Forced expiratory volume in one second $\left(F E V_{1}\right)$, forced vital capacity (FVC), inspiratory capacity

- Quality of sleep

- Nutritional status

- Patients' perception of coordination between hospital and home healthcare

- Patient satisfaction with therapy and care

- Adverse event related to regular clinical examination by an investigator

- Cost of illness (COI) analysis

- Absenteeism

\section{Step 3: International Delphi study for rating of content validity [58-61]}

Content validity was rated for 72 process and 21 outcome indicators by conducting an international Delphi study with a panel composed of 35 medical professionals from 15 countries. This panel consisted of 19 medical doctors, 8 nurses, and 8 physiotherapists. The detailed methodology and the results of this study are published [61] and appears as Chapter 4 in this dissertation.

In summary, panellists were asked to rate the relevance for follow-up of the process and outcome indicators in care pathways for COPD exacerbations. Consensus was defined as agreement by at least $75 \%$ of panel members that an indicator is relevant for follow-up. Consensus was reached for 26 of 72 process indicators (36.1\%) and 10 of 21 outcome 
indicators $(47.6 \%)$. Highest consensus was reached for the process indicators for oxygen therapy (100\%), pulmonary rehabilitation (100\%), and patient education (94.5 to $88.6 \%$ ), and for the outcome indicators for understanding of therapy (91.4 to 85.7\%) and selfmanagement (88.6 to $88.2 \%)$ [61].

\section{Step 4: Final selection of the clinical activities and grading of evidences}

Firslty, the list of 58 extracted clinical activities (step 2), together with the Delphi results (step 3 ), were sent by mail to the clinical experts of the panel (MD, TT, and CL) with a request to complete two tasks: (i) to review the 58 identified activities for validity and feasibility; and (ii) if indicated, to propose any additional clinical activities they believe are essential for in-hospital management of COPD exacerbations and which were lacking in the current list of clinical activities. Secondly, a consensus meeting was held with the entire expert panel (step 1) in order to make a final selection of the clinical activities. As a result, all 58 clinical activities were appraised to be valid and feasible. In addition, 19 clinical activities beyond the 58 original ones were included (Table 1, nos. 59-77). Interestingly, for almost all these additional clinical activities, a more or less comprehensive description was available in the guidelines for management of stable COPD [28;33;62].

Finally, strength of the evidence for the final 77 clinical activities was graded, so that clinicians know how much confidence they can place on the clinical recommendations included in the clinical care pathway [63]. The grading was performed by the clinical nurse specialist (CL) using the SIGN approach [20]. The systematic grading approach of SIGN was chosen because it is very transparent and workable from the perspective of the user of evidence-based recommendations [20;63;64]. Importantly, if the level of evidence could not be derived based on the selected literature out of the search in step 2, an additional literature search was performed in Medline, Embase, and Cochrane. Search terms included 'COPD' and key words related to the particular key intervention. Primarily, the search for additional evidence was focussed on reviews performed according to standard criteria for reviews [23]. If not available, an additional search for clinical trials was conducted. Subsequently, two other clinical experts of the panel (MD and TT) checked the final grading. As a result, 30 activities were graded as evidence level A (39.0\%), 39 activities as level B (50.6\%), 1 activity as level $C(1.3 \%)$, and 5 as level D (6.5\%) (Table 1$)$.

An extensive list of care activities was generated by following the above-mentioned steps. However, providing such an exhaustive list of 77 care activities to the multidisciplinary teams would likely not encourage them to use this evidence in practice. Therefore, the next two steps were specifically undertaken to distil the list of care activities to a set of key interventions that would be usuable and manageable in clinical practice. 


\section{Step 5: Clustering of clinical activities into key interventions and categorisation into process flow diagram}

Firstly, the 77 clinical activities were clustered into key interventions with subcomponents, based on the following criteria: (i) clinical activities are inextricably linked to each other (i.e. measurement of basal metabolic index (BMI), advice on malnutrition, supplementary nutrition, etc. were clustered into 'nutrition'); (ii) clinical activities need to be performed by a specific team member (i.e. breathing exercises, positioning, etc. were categorised under physiotherapy); (iii) clinical activities need to be performed at a specific time point or within a specific time span of the care process (i.e. activities regarding discharge management). As result, the 77 clinical activities were clustered into 38 key interventions, with 9 of them comprising 2-15 subcomponents (Appendix 1).

Secondly, the key interventions were categorised into three core processes (diagnostic, pharmacological, and non-pharmacological management) and subsequently presented by means of a process flow diagram. In addition, within each of three core processes, key interventions were grouped into care blocks based on the overall content of these key interventions (e.g. education, ventilation) (Appendix 1).

\section{Step 6: Detailed description of the key interventions (Figure 3)}

For each key intervention, the following components were included in the detailed description: (i) rationale, which addresses why it is of crucial importance that the key intervention is performed, and which describes expected impact on patient outcomes; (ii) description, which defines the exact content of the key intervention; (iii) in-text references and reference list; and (iv) grading of evidence (Figure 3). In order to search for detailed information on the description and the rationale, selected publications and their reference list were explored. Secondly, information from the additional literature search, performed to establish level of evidence (step 5), was included.

Figure 3: Example of detailed description of one key intervention: arterial blood gas measurement

\section{Argumentation}

Measurement of arterial blood gases (ABGs) is essential to detect hypercapnia and to assess the severity of an exacerbation. Consequently, $A B G$ values are the key determinant for initiating supplemental oxygen therapy, prescribing assisted ventilation, and prescribing home oxygen therapy. $\mathrm{A} \mathrm{PaO}_{2}<8.0 \mathrm{kPa}(60 \mathrm{~mm} \mathrm{Hg})$ and/or $\mathrm{SaO}_{2}<90 \%$ with or without $\mathrm{PaCO}_{2}>$ $6.7 \mathrm{kPa}(50 \mathrm{mmHg})$ when breathing room air indicate respiratory failure. In addition, moderateto-severe acidosis $(\mathrm{pH}<7.36)$ plus hypercapnia $\left(\mathrm{PaCO}_{2}>6-8 \mathrm{kPa} ; 45-60 \mathrm{mmHg}\right)$ in a patient with respiratory failure is an indication for mechanical ventilation (Barbera et al., 1997; Calverley, 2000; Celli et al., 2004; Gibson et al., 2008; GOLD, 2009; NICE, 2004; Rodriguez-Roisin, 2006; Siafkas \& Wedzicha, 2006).

In the Delphi study $82.9 \%$ of experts were convinced that the key intervention has a high impact on clinical outcomes and therefore should be included in the pathway. 
Description: (Celli et al., 2004; Gibson et al., 2008; GOLD, 2009; NICE, 2004; Rodriguez-Roisin, 2006; Siafkas \& Wedzicha, 2006)

Measurement of $\mathrm{PaO}_{2}, \mathrm{PaCO}_{2}, \mathrm{H}_{2} \mathrm{CO}_{3}^{-}, \mathrm{SaO}_{2}$, and $\mathrm{pH}$ by arterial puncture (a. radialis, brachialis, or femoralis) while breathing room air at admission. If measurement of ABGs while breathing room air is not feasible (severe cases), oxygen flow ( $/ / \mathrm{min}$ ) should be noted. Twenty to 30 minutes should pass before rechecking the gas tensions when the $\mathrm{FiO}_{2}$ has been changed.

\section{References:}

Barbera, J. A., Roca, J., Ferrer, A., Felez, M.A., Diaz, O., Roger, N., Rodriguez-Roisin, R. (1997). Mechanisms of worsening gas exchange during acute exacerbations of chronic obstructive pulmonary disease. European Respiratory Journal, 10, 1285-91.

Calverley, P.M. (2000). Oxygen-induced hypercapnia revisited. Lancet, 356:1538-1539.

Celli, B. R. \& Macnee, W. (2004). Standards for the diagnosis and treatment of patients with COPD: a summary of the ATS/ERS position paper. European Respiratory Journal, 23(6), 932-946.

Gibson G \& Macnee W. (2008). Chronic Obstructive pulmonary disease: Investigations and assessment of severity. In: Siafkas (Ed), European Respiratory Monograph: Management of exacerbation of chronic obstructive pulmonary disease (pp. 24-40). Sheffield: European Respiratory Society Ltd.

Global Initiative for Chronic Obstructive Lung Disease (GOLD) (2009). Global strategy for the diagnosis, management, and prevention of chronic obstructive pulmonary disease. Last accessed: January 27, 2010. http://www.goldcopd.com/Guidelineitem.asp?|1=2\&l2=1\&intld=2003

National Institute for Clinical Excellence (NICE) (2004). Chronic obstructive pulmonary disease: national clinical guideline for management of chronic obstructive pulmonary disease in adults in primary and secondary care. Thorax, 59 (Suppl. 1), 1-53.

Rodriguez-Roisin, R. (2006). COPD exacerbations: management. Thorax 61, 535-544.

Siafkas N. M. \& Wedzicha J. A. (2006). Management of exacerbation of COPD. In: Siafkas (Ed), European Respiratory Monograph: Management of exacerbation of chronic obstructive pulmonary disease ( $p p$. 387400). Sheffield: European Respiratory Society Ltd.

\section{Step 7: Translation into a set of process and outcome indicators [65-67]}

Besides the set of key interventions, a set of process and outcome indicators needed to be developed to verify compliance to key interventions and to follow up the impact on outcomes. Firstly, to select the final set of indicators, the expert panel convened for a consensus meeting. The selection process was based on the (updated) literature search (step 2), the Delphi survey (step 3), and the developed set of 38 evidence-based key interventions (step 5) [61]. As result, a set of 24 process and 15 outcome indicators was developed (Table 3 ). The 24 process indicators include measurements on performance of diagnostic, pharmacological, and non-pharmacological interventions. The 15 outcome indicators include measurements on readmission, mortality, length of stay (LOS), understanding of inhaler therapy, compliance with home oxygen therapy, performance of physical exercise, smoking status, anxiety and depression, health-related quality of life, management at home, functional status, self-reported health condition, medical consumption, and an economic evaluation (Table 3). On the basis of their expertise, the panel also selected a set of 15 baseline variables, including medical, socioeconomic, demographic, and COPD-specific data (Table 3). 
Table 3. Set of selected process and outcome indicators

\begin{tabular}{|c|c|c|c|}
\hline Process indicators & Typology & erion met & Unit \\
\hline $\begin{array}{l}\text { 1. Performance of arterial blood gas (ABG) } \\
\text { measurement during first } 24 \text { hours of admission }\end{array}$ & Process & $\begin{array}{l}\text { Performed in } \\
\text { all patients }\end{array}$ & Percentage \\
\hline $\begin{array}{l}\text { 2. Performance of chest X-ray during first } 24 \text { hours of } \\
\text { admission }^{\dagger}\end{array}$ & Process & $\begin{array}{l}\text { Performed in } \\
\text { all patients }\end{array}$ & Percentage \\
\hline $\begin{array}{l}\text { 3. Performance of electrocardiogram during first } 24 \\
\text { hours of admission }^{\dagger}\end{array}$ & Process & $\begin{array}{l}\text { Perforn } \\
\text { all patie }\end{array}$ & Percentage \\
\hline $\begin{array}{l}\text { 4. Performance of sputum culture and antibiogram } \\
\text { during hospitalisation (additional information) }\end{array}$ & Process & $\begin{array}{l}\text { Differences in } \\
\text { rates }\end{array}$ & Percentage \\
\hline 5. Measu & Process & sin & Percentage \\
\hline g bronchodilators & Process & & Percentage \\
\hline ion of long-acting bronchodilators & Process & & Percentage \\
\hline 8. Adequate prescription of systemic glucocorticoids ${ }^{\dagger}$ & Process & & Percentage \\
\hline 9. Prescription of antibiotics (additional information) & Process & & Percentage \\
\hline $\begin{array}{l}\text { 10. Administration of controlled oxygen therapy in } \\
\text { patients hypoxaemic during admission }{ }^{\dagger}\end{array}$ & Process & in & Percentage \\
\hline 11. Asse & Process & & Percentage \\
\hline $\begin{array}{l}\text { 12. Smoking cessation intervention in active smokers at } \\
\text { admission }^{\dagger}\end{array}$ & Process & & ntage \\
\hline ucation regarding inhaler & Process & & Percentage \\
\hline 14. Adequate education regarding home oxygen therapy ${ }^{\dagger}$ & Process & & Percentage \\
\hline mance of rehabilitation tests during the past & Process & & Percentage \\
\hline $\begin{array}{l}\text { 16. Referral to pulmonary rehabilitation during the past } \\
\text { year }^{\dagger}\end{array}$ & Process & in & tage \\
\hline 17. Assessment of nutritional status & Process & & ntage \\
\hline 18. Adequate management of underweight ${ }^{\dagger}$ & Process & & Percentage \\
\hline 19. Adequate management of overweight ${ }^{\dagger}$ & Process & & Percentage \\
\hline 20. Scr & Process & $\begin{array}{l}\text { formed in } \\
\text { patients }\end{array}$ & Percentage \\
\hline raccination & Proce & $\begin{array}{l}\text { rmed in } \\
\text { tients }\end{array}$ & Percentage \\
\hline $\begin{array}{l}\text { 22. Measurement of ABGs } 1 \text { or } 2 \text { days before discharge } \\
\text { inpatients hypoxemic at admission }\end{array}$ & Process & $\begin{array}{l}\text { Performed in } \\
\text { all patients }\end{array}$ & Percentage \\
\hline $\begin{array}{l}\text { 23. Prescription of home oxygen therapy in patients } \\
\text { hypoxaemic at discharge }^{\dagger}\end{array}$ & Process & $\begin{array}{l}\text { Performed in } \\
\text { all patients }\end{array}$ & Percentage \\
\hline
\end{tabular}




\begin{tabular}{|c|c|c|c|}
\hline 24. Adequate discharge management ${ }^{\dagger}$ & Process & $\begin{array}{l}\text { Performed in } \\
\text { all patients }\end{array}$ & Percentage \\
\hline Outcome indicators & Typology & Criterion met & Unit \\
\hline 1. Readmission: 30-day, 6-month & Outcome & $\begin{array}{l}\text { Differences in } \\
\text { rates }\end{array}$ & Percentage \\
\hline 2. Mortality: In-hospital, 30-day, 6-month & Outcome & $\begin{array}{l}\text { Differences in } \\
\text { rates }\end{array}$ & Percentage \\
\hline 3. Length of stay (LOS) & Outcome & $\begin{array}{l}\text { Differences in } \\
\text { values }\end{array}$ & Days \\
\hline 4. Level of understanding of inhaler therapy & Outcome & $\begin{array}{l}\text { Differences in } \\
\text { values }\end{array}$ & Score \\
\hline $\begin{array}{l}\text { 5. Compliance with home oxygen therapy } 30 \text { days after } \\
\text { discharge }^{a}\end{array}$ & Outcome & $\begin{array}{l}\text { Differences in } \\
\text { values }\end{array}$ & Score \\
\hline $\begin{array}{l}\text { 6. Performance of physical exercise during } 30 \text { days after } \\
\text { discharge }\end{array}$ & Outcome & $\begin{array}{l}\text { Differences in } \\
\text { values }\end{array}$ & Score \\
\hline $\begin{array}{l}\text { 7. Smoking status: } 30 \text { days after discharge, } 6 \text { months } \\
\text { after discharge }\end{array}$ & Outcome & $\begin{array}{l}\text { Differences in } \\
\text { rates }\end{array}$ & Percentage \\
\hline $\begin{array}{l}\text { 8. Symptoms of anxiety and depression: at discharge, } \\
30 \text { days after discharge } \\
\text { Hospital Anxiety and Depression Scale (HADS) } \\
\text { (Zigmond } 1983\end{array}$ & Outcome & $\begin{array}{l}\text { Differences in } \\
\text { rates }\end{array}$ & Percentage \\
\hline $\begin{array}{l}\text { 9. Health-related quality of life (HRQL) } 30 \text { days after } \\
\text { discharge } \\
\text { Saint George Respiratory Questionnaire (SGRQ )[68] }\end{array}$ & Outcome & $\begin{array}{l}\text { Differences in } \\
\text { values }\end{array}$ & Score \\
\hline $\begin{array}{l}\text { 10. Able to cope at home/place of residence at } 30 \text { days } \\
\text { after discharge }\end{array}$ & Outcome & $\begin{array}{l}\text { Differences in } \\
\text { values }\end{array}$ & Score \\
\hline $\begin{array}{l}\text { 11. Functional status: at discharge, } 30 \text { days and } 6 \\
\text { months after discharge } \\
\text { Katz Scale [69] }\end{array}$ & Outcome & $\begin{array}{l}\text { Differences in } \\
\text { rates }\end{array}$ & Percentage \\
\hline $\begin{array}{l}\text { 12. Self-reported health condition: at discharge, } 30 \text { days } \\
\text { and } 6 \text { months after discharge }\end{array}$ & Outcome & $\begin{array}{l}\text { Differences in } \\
\text { values }\end{array}$ & Score \\
\hline $\begin{array}{l}\text { 13. Severity of breathlessness at } 30 \text { days after discharge } \\
\text { Modified Medical Research Council Dyspnoea scale } \\
\text { [70] }\end{array}$ & Outcome & $\begin{array}{l}\text { Differences in } \\
\text { values }\end{array}$ & Score \\
\hline $\begin{array}{l}\text { 14. Number of visits by general practitioner at } 30 \text { days } \\
\text { after discharge }\end{array}$ & Outcome & $\begin{array}{l}\text { Differences in } \\
\text { values }\end{array}$ & Score \\
\hline $\begin{array}{l}\text { 15. Health status } \\
\text { http://www.euroqol.org/ }\end{array}$ & Outcome & $\begin{array}{l}\text { Used for } \\
\text { economic } \\
\text { analyses }\end{array}$ & Score \\
\hline
\end{tabular}

\section{Baseline variables}

- Socioeconomic variables: income, medical insurance, level of education, profession

- Demographic variables: age, gender, nationality

- COPD-related variables: COPD severity, comorbidities, cognitive status, smoking status at admission, COPD-related hospitalisation in the previous year, medication prescribed before hospitalisation, use of home oxygen therapy before admission, body mass index, lung function parameters before discharge, arterial blood gas values at admission, non-invasive positive pressure ventilation (NIPPV)

\footnotetext{
${ }^{\dagger}$ Multi-component indicators.
} 
Subsequently, the selected indicators and baseline variables were operationalised into objective measurements [66]. Based on the guidance of the Agency for Health Care Research and Quality (www.qualitymeasures.ahrq.gov) and the Joint Commission (www.jointcommission.org), each indicator and baseline variable was defined in an indicator protocol by the main researcher $(\mathrm{CL})$. This process included defining of description, rationale or relation to quality, type of indicator (process, outcome, baseline), nominator and denominator, data collection method, data elements, data reporting (i.e. proportion, relative proportion), criteria to meet, expected outcomes, and references (Figure 4). Subsequently, the indicator protocol was mailed to the entire expert panel with a request to appraise each indicator description thoroughly for accuracy and feasibility. A meeting with the entire expert panel was convened to discuss the feedback and finalise the indicator protocol.

Figure 4. Example description on an indicator

\begin{tabular}{|c|c|}
\hline $\begin{array}{l}\text { Indicator } \\
\text { number }\end{array}$ & 2.1. \\
\hline Indicator name & Arterial blood gas (ABG) measurement at admission \\
\hline Description & $\begin{array}{l}\text { At admission, measurement of } \mathrm{PaO}_{2}, \mathrm{PaCO}_{2}, \mathrm{H}_{2} \mathrm{CO}_{3}^{-}, \mathrm{SaO}_{2} \text {, and } \mathrm{pH} \text { by arterial } \\
\text { puncture (radialis, brachialis, or femoralis), while breathing room air in patients } \\
\text { admitted with the principal diagnosis ICD-9-CM code } 491.21 \text {. } \\
\text { If measurement of } \mathrm{ABG} \text { while breathing room air is not feasible (severe cases), } \\
\text { oxygen flow ( } / \text { min) should be noted. Twenty to } 30 \text { minutes should pass before } \\
\text { rechecking the } \mathrm{ABG} \text { tensions when the } \mathrm{FiO}_{2} \text { has been changed. }\end{array}$ \\
\hline $\begin{array}{l}\text { Rationale/ } \\
\text { Relation to } \\
\text { quality }\end{array}$ & $\begin{array}{l}\text { Blood gas monitoring is mandatory for patients that require hospitalisation during } \\
\text { acute exacerbations of COPD, as measurement of } \mathrm{ABGs} \text { is important to assess } \\
\text { the severity of an exacerbation. } \mathrm{A} \mathrm{PaO} 2<8.0 \mathrm{kPa}(60 \mathrm{~mm} \mathrm{Hg}) \text { and/or } \mathrm{SaO}_{2}<90 \% \\
\text { with or without } \mathrm{PaCO}_{2}>6.7 \mathrm{kPa}(50 \mathrm{mmHg} \text { ) when breathing room air indicate } \\
\text { respiratory failure. In addition, moderate-to-severe acidosis (pH }<7.36 \text { ) plus } \\
\text { hypercapnia ( } \mathrm{PaCO} \mathrm{CO}_{2}>6-8 \mathrm{kPa} ; 45-60 \mathrm{mmHg} \text { ) in a patient with respiratory failure } \\
\text { is an indication for mechanical ventilation. Since arterial blood pH is usually } \\
\text { relatively normal in stable COPD, its value during an hypercapnic exacerbation is } \\
\text { a useful index of the acute rise in } \mathrm{PaCO}_{2} \text {, and in turn, is also related to the } \\
\text { prognosis of the exacerbation. In conclusion, failing to obtain patients' ABGs may } \\
\text { lead to suboptimal management, as } \mathrm{ABG} \text { values are an important determinant } \\
\text { for initiating supplemental oxygen therapy, for prescribing assisted ventilation, } \\
\text { and for prescribing home oxygen therapy. Furthermore, patients presenting with } \\
\text { exacerbations often suffer from hypercapnia, which can only be detected through } \\
\text { ABG measurement. Studies point out that performance of ABGs range from } 44 \% \\
\text { to } 84 \% \text {, with a variance across hospitals of more than } 20 \% \text {. }\end{array}$ \\
\hline $\begin{array}{l}\text { Type of } \\
\text { indicator }\end{array}$ & Process \\
\hline Numerator & $\begin{array}{l}\text { Number of patients in which ABG measurement at admission was performed } \\
\text { among cases meeting the inclusion and exclusion criteria for the denominator } \\
\text { among cases meeting the inclusion and exclusion criteria for the denominator. }\end{array}$ \\
\hline Denominator & $\begin{array}{l}\text { Total number of patients discharged with a principal diagnosis ICD-9-CM code } \\
491.21 \text { as defined in Preface Table } 1 . \\
\text { Inclusion criteria: all inclusion criteria defined in Preface Table } 2 . \\
\text { Exclusion criteria: all exclusion criteria defined in Preface Table } 2 .\end{array}$ \\
\hline
\end{tabular}




\begin{tabular}{|c|c|}
\hline $\begin{array}{l}\text { Data collection } \\
\text { method }\end{array}$ & $\begin{array}{l}\text { Retrospective: Patient record } \\
\text { Who: External researcher } \\
\text { Time point: After discharge from the ward } \\
\frac{\text { Data: }}{\text { - }} \text { ABG measurement within first } 24 \text { hours of admission? (ABGAD) } \\
\text { Data for check: } \\
\text { - Date of admission (PRADDate) } \\
\text { - Date of first } A B G \text { measurements at admission }(A B G A D D a) \\
\text { - } A B G \text { values }\left(\mathrm{PaO}_{2}, \mathrm{PaCO}_{2}, \mathrm{pH}, \mathrm{SaO}_{2}, \mathrm{H}_{2} \mathrm{CO}_{3}\right) \text { measured at times } 1,2 \text {, } \\
\quad \text { and } 3\end{array}$ \\
\hline $\begin{array}{l}\text { Data elements } \\
\text { for indicator }\end{array}$ & - $\mathrm{ABG}$ measurement at day of admission? (ABGAD) \\
\hline $\begin{array}{l}\text { Data reported } \\
\text { as }\end{array}$ & Aggregate rate $(\%)$ generated form count data $(n)$ reported as proportion $(n / n)$ \\
\hline $\begin{array}{l}\text { Expected } \\
\text { outcome }\end{array}$ & $44-84 \%$ \\
\hline Criteria to meet & Performed in all patients $(100 \%)$ \\
\hline References: & $\begin{array}{l}\text { (Barbera et al., 1997; Bratzler et al., 2004; Calverley, 2000; Celli \& Macnee, } \\
\text { 2004; Chang et al., 2007; Cydulka et al., 2003; Gibson \& Macnee, 2008; Global } \\
\text { Initiative for Chronic Obstructive Lung Disease, 2008a; Harvey et al., 2005; Kelly } \\
\text { \& Elborn, 2002; Lindenauer et al., 2006b; Roberts et al., 2001; Rodriguez-Roisin, } \\
\text { 2006a; Siafkas \& Wedzicha, 2006) }\end{array}$ \\
\hline
\end{tabular}

Finally, based on the indicator protocol, the objective measurement forms were developed by the main researcher $(\mathrm{CL})$. In summary, data collection need to be performed at three time points, including: a structured interview performed by a team member at discharge from the ward, patient questionnaires completed at discharge from the ward, patient questionnaires completed 30 days after discharge from the ward, and two structured telephone interviews performed by the study coordinator 30 days and 6 months after discharge from the ward. Additionally, a patient record analysis is performed by the study coordinator after inclusion of the 20 patients. The completed forms were sent to the entire expert panel for feedback, and during a subsequent consensus meeting, the forms were discussed and finalised.

\section{Step 8: Piloting by multidisciplinary teams}

The set of 38 key interventions, and the set of 24 process and 15 outcome indicators, were piloted by nine Belgian experimental COPD teams in the context of the EQCP study [9]. The multidisciplinary teams included pulmonologists, nurses, physiotherapists, dieticians, social workers, and ergotherapists. The piloting occurred in four phases. Firstly, feasibility of data collection was evaluated during a clinical audit before pathway implementation. For this phase, 105 patients from nine hospitals were included [9]. Mean age was 67 years (SD: 10.0 ), and $68.6 \%$ of patients were male. Approximately half of the patients had severe COPD, $21 \%$ had moderate COPD, and another $21.9 \%$ had very severe COPD. Overall, after 
data analyses we determined that data collection is feasible, and only minor adaptations in the patient record analysis were made.

Secondly, during a workshop in which team members of all nine multidisciplinary COPD teams attended, the process flow diagram, including the 38 key interventions, was presented. Subsequently, all possible remarks were extensively discussed. Thirdly, the detailed set of key interventions was mailed as pdf to the study coordinator of each hospital. We requested that all members of the multidisciplinary COPD team extensively review the key intervention set and subsequently to provide feedback within two weeks. As a result, the feedback given during the workshop and provided after extensive appraisal by all teams showed that teams were very enthusiastic about the process flow diagram and underlying key interventions. Moreover, they agreed by consensus that the set of key interventions was valid and applicable for use in their practice. Six main remarks regarding spirometry, inhaler medications, content and workload of patient education, and feasibility of pulmonary rehabilitation were provided by the teams. All remarks were thoroughly appraised by the expert panel and discussed with the teams, and after consensus the necessary modifications were made.

Finally, the nine multidisciplinary COPD teams implemented the set of key interventions as an active component of their care pathway for in-hospital management of COPD exacerbation in the context of the EQCP study [9]. Six months after start of development and implementation of the care pathway, the nine teams had the opportunity to report experiences, barriers, and successful actions during a workshop. One major difficulty in implementing the educational package into a team's daily work routine was reported. Overall, the teams confirmed validity and clinical applicability of the set of 38 key interventions.

\section{Discussion}

A set of 38 evidence-based key interventions for in-hospital management of COPD exacerbation was developed (Appendix 1) and subsequently piloted and approved for validity and clinical applicability by nine Belgian multidisciplinary COPD teams from nine different hospitals. This unanimous approval indicates that the set of key interventions is appropriate for the development and standardisation of the clinical content of the evidence-based care pathway for COPD exacerbation. Secondly, a set of 24 process and 15 outcome indicators was also developed. The pilot study showed that the measurements on the indicators were feasible for the multidisciplinary teams and the patients; only some minor adaptations were required.

The literature on management of COPD is mostly in agreement, including congruency of guidelines, process flow diagrams, and reviews. Only two important discrepancies 
concerning sputum culture and performance of spirometric tests were found [71]. Availability of rigorous evidence was very beneficial for 'easy' selection of the care activities (step 4). For other disease states, such as proximal femur fracture (PFF), conflicting evidence exists, or available evidence is scarce (www.mapofmedicine.com/hipfracture). This situation will considerably complicate the selection and description of the key interventions for PFF.

The applied strategy will likely inspire and guide other teams in the development of evidence-based content of their own future care pathways. It is important to note that designing the care pathway content according to the eight-step strategy is a time-consuming process, especially with regard to the Delphi survey (step 3) and pilot testing (step 8). However, results of the Delphi survey and piloting are essential to ensure that the key intervention set is widely clinically applicable. This is especially important when conducting a CRCT, in which the 'same' care pathway intervention needs to be implemented by different teams at different sites and possibly in different countries [9]. Teams developing care pathways should budget enough time in their project plan for proper development of the clinical content of their care pathway.

An important limitation in the current strategy is the lack of patient involvement [72]. Patients can bring a different perspective to the quality improvement process, as they are likely to prioritise different aspects of care compared to clinicians, including interpersonal and amenity aspects; for example, communication with healthcare staff and quality of the food, rather than the technical and clinical aspects [73]. We believe that patients, for instance by contacting patient societies, should have been involved in three phases of the eight-step method: (i) step 4: final selection of the clinical activities; (ii) step 7: Translation of outcome measures; and (ii) step 8: piloting of the final set of key interventions. Including patients in these phases could have provided extra activities and outcomes, important from the patient perspective. After implementation of the key interventions, it will be interesting to gather information on patient preferences and opinions by performing open interviews with the patient and relatives, or by performing walkthroughs together with the patient [74]. Also, when applying the evidence-based care intervention in daily practice, clinicians should ensure that each of their individual patients are involved in decision making [72]. In this context, it is also recommended to develop a patient version that includes a brief and understandable summary of the set of key interventions.

We believe that developing the clinical care pathway content by using this newly developed and validated eight-step method will facilitate adequate integration of evidencebased knowledge into daily practice. Since the beginning of the 1990s, evidence-based clinical practice guidelines for almost all domains of medicine have been available worldwide, accessible more recently via the Internet $[4 ; 71 ; 75]$. However, we see high variability in the integration of knowledge from evidence-based guidelines into daily practice [4;76]. Common 
barriers for integration of evidence-based knowledge are disagreement with the evidence; lack of outcome expectancy; lack of time; and available evidence, such as guidelines being unnecessarily complex, and thus not so directly applicable for clinical practice $[4 ; 76 ; 77]$. This eight-step methodology can facilitate translation of evidence-based knowledge into clinically applicable key interventions, which can overcome barriers and assist clinicians both in selecting best treatment options and in delivering safe and effective care [4]. However, besides providing a set of detailed evidence-based key interventions, consideration of factors like culture (safety, commitment to do better in practice, peer norms); teamwork; skills management; communication; leadership alignment; and support will be critical to successfully integrate evidence into practice and improve the care process [78]. In this context, care pathways can be very effective tools, as they bring all these pieces together [8;26;79].

Finally, we want to emphasise the potential role of professional medical associations in clinical content development for evidence-based care pathways. Many national and international societies have extensive clinical and research experience in the patient population of their clinical field, comprise a global network of experts in the field, have funding available, and, last but not least, have comprehensive understanding and experience in synthesising evidence-based knowledge and making this knowledge usable for daily clinical practice. Therefore, we think that professional societies could play a major role in developing the clinical content of future evidence-based care pathways, especially in terms of clinical support, expert networking, and input of resources.

\section{Conclusion}

The set of 38 key interventions was determined to be appropriate for the development and standardisation of clinical content of the COPD care pathway. Implementation of the set of key interventions in the three other countries involved in the EQCP study (Italy, Ireland, and Portugal) will provide additional information on transferability of the key intervention set to other countries. The novel eight-step method developed in this PhD work will likely help teams to shape the clinical content of their future evidence-based care pathways; for instance, those developed for pathologies such as hip fracture, heart failure, and diabetes.

\section{Acknowledgements}

We acknowledge the support of the Clinical Research Fund of UZ Leuven, Belgium. We also acknowledge Pfizer Belgium, Pfizer Italy, Pfizer Ireland, and Pfizer Portugal, who supported this research by providing an unrestricted educational grant. The autonomy of E-P-A and all 
involved academic institutions with regard to scientific independence and intellectual property on methodology is guaranteed. We further thank the Map of Medicine ${ }^{\circledR}$ for providing us evidence-based information, which helped us to develop the clinical pathway content. We acknowledge Rafaela Camacho Bejarano and Thierry Troosters for performing a pre-peer review of the manuscript. 


\section{References}

1. Institute of Medicine. Creating safety systems in helath care organizatoins: To err is human: building a safer health system. Washington, DC, National Academy Press, 2000, pp 155-201.

2. Grol R, Grimshaw J. From evidence to best practice: Effective implementation of change in patients' care. Lancet 2003;362:1225-1230.

3. Grol R, Wensing M. What drives change? Barriers to incentives for achieveing evidence based practice. Med J Aust 2004;180:S57-S60.

4. Institute of Medicine. Applying evidence to health care delivery. Crossing the quallity chasm: A new health system for the $21^{\text {st }}$ century. Washington, DC, National Academy Press, 2001, pp 145-163.

5. Lodewijckx C, Sermeus W, Vanhaecht k, Panella M, Deneckere S, Leigheb F, Decramer M. Inhospital management of COPD exacerbations: a systematic review of the literature with regard to adherence to international guidelines. Journal of Evaluation in Clinical Practice 2009;15:1101-1110.

6. Campbell H, Hotchkiss R, Bradshaw N, Porteous M. Integrated care pathways. BMJ 1998;316:133-137.

7. Pearson SD, Goulart-Fisher D, Lee TH. Critical pathways as a strategy for improving care: problems and potential. Ann Intern Med 1995;123:941-948.

8. Vanhaecht K, De Witte K, Sermeus W. The Care Process Organisation Triangle: A framework to better understand how clinical pathways work. Intl J Care Pathw 2007;11:18.

9. Vanhaecht K, Sermeus W, Peers J, Lodewijckx C, Deneckere S, Leigheb F, Decramer M, Panella M. The impact of care pathways for exacerbation of Chronic Obstructive Pulmonary Disease: rationale and design of a cluster randomized controlled trial. Trials 2010;11:111.

10. Medical Research Council (2008). Developing and evaluating complex interventions: new guidance, 2008. [http://www.mrc.ac.uk/Utilities/Documentrecord/index.htm?d=MRC004871]

11. Sermeus W, De Bleser L, Depreitere R, Dewaele K, Vanhaecht k, Vlayen J. An introduction to clinical pathways. In Devriese S, Lambert M, Eyssen M, Van de Sande S, Poelmans J, Van Brabandt H, Sermeus W, Vlayen J, Ramaekers D, (eds): The use of clinical pathways and guidelines to determine physicians' hospital fees prospectively: easier said than done.T. Brussels, Belgian Healthcare Knowledge Centre (KCE). KCE Reports, Volume 18A, 2005. [http:/www.kenniscentrum.fgov.be/nl/publicaties.html]. 
12. Medical Research Council (MRC). Cluster Randomised Trials: Methodological and ethical considerations. Medical Research Council (MRC) 2002. [http://open.mrc.gm/Statsdatamgt/stats\&datam_files/MRCguide_cluster.pdf]

13. Oakley A, Strange V, Bonell C, Allen E, Stephenson J. Process evaluation in randomised controlled trials of complex interventions. BMJ 2006;332:413-416.

14. Vanhaecht K, Ovretveit J, Elliott MJ, Sermeus W, Ellershaw J, Panella M. Have we drawn the wrong conclusions about the value of care pathways? Is a Cochrane review appropriate? Eval Health Prof 2012;35:28-42.

15. Hawe P, Shiell A, Riley T. Complex interventions: how "out of control" can a randomised controlled trial be? BMJ 2004;328:1561-1563.

16. Berry SA, Doll MC, McKinley KE, Casale AS, Bothe A, Jr.. ProvenCare: quality improvement model for designing highly reliable care in cardiac surgery. Qual Saf Health Care 2009;18:360-368.

17. Schunemann HJ, Cook D, Guyatt G. Methodology for antithrombotic and thrombolytic therapy guideline development: American College of Chest Physicians Evidence-based Clinical Practice Guidelines (8th Edition). Chest 2008;133:113S-122S.

18. Schunemann HJ, Hill SR, Kakad M, Vist GE, Bellamy R, Stockman L, Wisloff TF, Del MC, Hayden F, Uyeki TM, Farrar J, Yazdanpanah Y, Zucker H, Beigel J, Chotpitayasunondh T, Hien TT, Ozbay B, Sugaya N, Oxman AD. Transparent development of the WHO rapid advice guidelines. PLoS Med 2007;4:e119.

19. Umscheid CA, Agarwal RK, Brennan PJ. Updating the guideline development methodology of the Healthcare Infection Control Practices Advisory Committee (HICPAC). Am J Infect Control 2010;38:264-273.

20. Scottish Intercollegiate Guidelines Network: SIGN 50 A guideline developer's handbook: Annex B; 2008. [http://www.sign.ac.uk/guidelines/fulltext/50/annexb.html]

21. Goldmann D. Five puzzle pieces, ten cautionary notes. Intl J Care Pathw 2010;14:33-35.

22. Vanhaecht K, Deneckere S, Van Gerven E, Lodewijckx C, Janssens I, Van Zelm R, Boto $P$, Panella M, Biringer E, Sermeus W. The 7-phase method to design, implement and evaluate care pathways. Int J Pers Cent Med 2011. In press.

23. NHS Centre for Reviews and Dissemination. Undertaking Systematic Reviews of Research on Effectiveness: CRD's Guidance for Those Carrying Out or Commissioning Reviews; in NHS Centre for Reviews and Dissemination, (ed): York, UK, 2001. [http://www.york.ac.uk/inst/crd/crdreports.htm]

24. Anzueto A, Sethi S, Martinez FJ. Exacerbations of chronic obstructive pulmonary disease. Proc Am Thorac Soc 2007;4:554-564.

25. BMJ. Acute exacerbation of chronic obstructive pulmonary disease; 2012. [http://bestpractice.bmj.com/best-practice/monograph/8.html] 
26. Cazzola M, Macnee W, Martinez FJ, Rabe KF, Franciosi LG, Barnes PJ, Brusasco V, Burge PS, Calverley PM, Celli BR, Jones PW, Mahler DA, Make B, Miravitlles M, Page CP, Palange P, Parr D, Pistolesi M, Rennard SI, Rutten-van Molken MP, Stockley R, Sullivan SD, Wedzicha JA, Wouters EF. Outcomes for COPD pharmacological trials: from lung function to biomarkers. Eur Respir J 2008;31:416-469.

27. Evensen AE. Management of COPD exacerbations. American Family Physician 2010;81:607-613.

28. Global Initiative for Chronic Obstructive Lung Disease (GOLD):: Global strategy for the diagnosis, management, and prevention of chronic obstructive pulmonary disease, updated 2010. [http://www.goldcopd.org/guidelines-global-strategy-for-diagnosismanagement.html]

29. Glaab T, Vogelmeier C, Buhl R. Outcome measures in chronic obstructive pulmonary disease (COPD): strengths and limitations. Respir Res 2010;11:79.

30. Hurst JR, Wedzicha JA. Management and prevention of chronic obstructive pulmonary disease exacerbations: a state of the art review. BMC Med 2009;7:40.

31. Kunisaki KM, Rice KL, Niewoehner DE. Management of acute exacerbations of chronic obstructive pulmonary disease in the elderly: an appraisal of published evidence. Drugs Aging 2007;24:303-324.

32. Map of Medicine. Specialist management of acute exacerbation.; Londen, Map of Medicine, 2009. [http://www.mapofmedicine.com]

33. National Institute for Health and Clinical Excellence (NICE). Chronic obstructive pulmonary disease - Management of chronic obstructive pulmonary disease in adults in primary and secondary care; 2010. [http://guidance.nice.org.uk/CG101]

34. Osthoff M, Leuppi JD. Management of chronic obstructive pulmonary disease patients after hospitalization for acute exacerbation. Respiration 2010;79:255-261.

35. Rabbat A, Guetta A, Lorut C, Lefebvre A, Roche N, Huchon G. Management of acute exacerbations of COPD. Rev Mal Respir 2010;27:939-953.

36. Rodriguez-Roisin R. COPD exacerbations. Management. Thorax 2006;61:535-544.

37. Scullion J. Patient-focused outcomes in chronic obstructive pulmonary disease. Nurs Stand 2008;22:50-56.

38. Siafkas N, Wedzicha J. Management of acute exacerbation of chronic obstructive pulmonary disease. In Siafkas N, (ed): Management of chronic obstructive pulmonary disease. European Respiratory Monograph. Sheffield, European Respiratory Society Ltd, 2006, vol 11, pp 387-400.

39. Vogelmeier C, Buhl R, Criee CP, Gillissen A, Kardos P, Kohler D, Magnussen H, Morr H, Nowak D, Pfeiffer-Kascha D, Petro W, Rabe K, Schultz K, Sitter H, Teschler H, Welte T, Wettengel $\mathrm{R}$, Worth $\mathrm{H}$. [Guidelines for the diagnosis and therapy of COPD issued by 
Deutsche Atemwegsliga and Deutsche Gesellschaft fur Pneumologie und Beatmungsmedizin]. Pneumologie 2007;61:e1-40.

40. Bahadori K, FitzGerald JM. Risk factors of hospitalization and readmission of patients with COPD exacerbation--systematic review. Int $\mathrm{J}$ Chron Obstruct Pulmon Dis 2007;2:241-251.

41. Chenna PR, Mannino DM. Outcomes of severe COPD exacerbations requiring hospitalization. Semin Respir Crit Care Med 2010;31:286-294.

42. Dal Negro R. Optimizing economic outcomes in the management of COPD. Int J Chron Obstruct Pulmon Dis 2008;3:1-10.

43. Decramer M, Celli B, Kesten S, Lystig T, Mehra S, Tashkin DP. Effect of tiotropium on outcomes in patients with moderate chronic obstructive pulmonary disease (UPLIFT): a prespecified subgroup analysis of a randomised controlled trial. Lancet 2009;374:11711178.

44. Doll H, Miravitlles M. Health-related QOL in acute exacerbations of chronic bronchitis and chronic obstructive pulmonary disease: a review of the literature. Pharmacoeconomics 2005;23:345-363.

45. Effing T, Monninkhof EM, Van Der V, Van Der PJ, van Herwaarden CL, Partidge MR, Walters EH, Zielhuis GA. Self-management education for patients with chronic obstructive pulmonary disease. Cochrane Database Syst Rev 2007;CD002990.

46. Eisner MD, Blanc PD, Yelin EH, Katz PP, Sanchez G, Iribarren C, Omachi TA: Influence of anxiety on health outcomes in COPD. Thorax 2010;65:229-234.

47. Gartlehner G, Hansen RA, Carson SS, Lohr KN. Efficacy and safety of inhaled corticosteroids in patients with COPD: a systematic review and meta-analysis of health outcomes. Ann Fam Med 2006;4:253-262.

48. Hartman JE, Boezen HM, de Greef MH, Bossenbroek L, Ten Hacken NH. Consequences of physical inactivity in chronic obstructive pulmonary disease. Expert Rev Respir Med 2010;4:735-745.

49. Lodewijckx C, Sermeus W, Panella M, Deneckere S, Leigheb F, Decramer M, Vanhaecht K. Impact of care pathways for in-hospital management of COPD exacerbation: a systematic review. Int J Nurs Stud 2011;48:1445-1456.

50. Poole PJ, Chacko E, Wood-Baker RW, Cates CJ. Influenza vaccine for patients with chronic obstructive pulmonary disease. Cochrane Database Syst Rev 2006;CD002733.

51. Roche N, Rabbat A, Zureik M, Huchon G. Chronic obstructive pulmonary disease exacerbations in emergency departments: predictors of outcome. Curr Opin Pulm Med 2010;16:112-117. 
52. Rotter T, Kinsman L, James E, Machotta A, Gothe H, Willis J, Snow P, Kugler J. Clinical pathways: effects on professional practice, patient outcomes, length of stay and hospital costs. Cochrane Database Syst Rev 2010;3:CD006632.

53. Seemungal TA, Hurst JR, Wedzicha JA. Exacerbation rate, health status and mortality in COPD--a review of potential interventions. Int J Chron Obstruct Pulmon Dis 2009;4:203223.

54. Steer J, Gibson GJ, Bourke SC. Predicting outcomes following hospitalization for acute exacerbations of COPD. QJM 2010;103:817-829.

55. Stockley RA, Whitehead PJ, Williams MK. Improved outcomes in patients with chronic obstructive pulmonary disease treated with salmeterol compared with placebo/usual therapy: results of a meta-analysis. Respir Res 2006;7:147.

56. Van Wetering CR, Hoogendoorn M, Mol SJ, Rutten-van Molken MP, Schols AM. Shortand long-term efficacy of a community-based COPD management programme in less advanced COPD: a randomised controlled trial. Thorax 2010;65:7-13.

57. Yohannes AM, Willgoss TG, Vestbo J.: Tiotropium for treatment of stable COPD: a metaanalysis of clinically relevant outcomes. Respir Care 2011;56:477-487.

58. Campbell SM, Braspenning J, Hutchinson A, Marshall MN. Research methods used in developing and applying quality indicators in primary care. BMJ 2003;326:816-819.

59. Hasson F, Keeney S, McKenna H. Research guidelines for the Delphi survey technique. J Adv Nurs 2000;32:1008-1015.

60. Keeney S, Hasson F, McKenna H. Consulting the oracle: ten lessons from using the Delphi technique in nursing research. J Adv Nurs 2006;53:205-212.

61. Lodewijckx C, Sermeus W, Panella M, Deneckere S, Leigheb F, Troosters T, Boto P, Mendeze R, Decramer M, Vanhaecht K. Quality indicators for in-hospital management of exacerbation of chronic obstructive pulmonary disease: results of an international Delphi study. J Adv Nurs. 2012. [Epub ahead of print].

62. Siafkas N. Management of chronic obstructive pulmonary disease. Sheffield, European Respiratory Society Ltd, 2006.

63. Atkins D, Best D, Briss PA, Eccles M, Falck-Ytter Y, Flottorp S, Guyatt GH, Harbour RT, Haugh MC, Henry D, Hill S, Jaeschke R, Leng G, Liberati A, Magrini N, Mason J, Middleton P, Mrukowicz J, O'Connell D, Oxman AD, Phillips B, Schunemann HJ, Edejer TT, Varonen H, Vist GE, Williams JW, Jr., Zaza S. Grading quality of evidence and strength of recommendations. BMJ 2004;328:1490.

64. Atkins D, Eccles M, Flottorp S, Guyatt GH, Henry D, Hill S, Liberati A, O'Connell D, Oxman AD, Phillips B, Schunemann H, Edejer TT, Vist GE, Williams JW, Jr. Systems for grading the quality of evidence and the strength of recommendations I: critical appraisal of existing approaches The GRADE Working Group. BMC Health Serv Res 2004;4:38. 
65. Department of Health and Human Services Agency for Healthcare Research and Quality: Guide to Inpatient Quality Indicators: Quality of Care in Hospitals - Volume, Mortality, and Utilization; 2007. [http://www.qualityindicators.ahrq.gov/downloads/iqi/iqi_guide_v31.pdf]

66. Mainz J: Defining and classifying clinical indicators for quality improvement. Int J Qual Health Care 2003;15:523-530.

67. The Joint Commission. Performance Measurements Initiative: Current Specification Manual for National Hospital Quality Measures; 2009.

[http://www.jointcommission.org/PerformanceMeasurement/PerformanceMeasurement/C urrent+NHQM+Manual.htm]

68. Jones PW, Quirk FH, Baveystock CM. The St George's Respiratory Questionnaire. Respir Med 1991;85 Suppl B:25-31.

69. Katz S, Ford AB, Moskowitz RW, Jackson BA, Jaffe MWO. Studies of illness in the aged: A standardized measure of biological and phsychosocial function. JAMA 1963;185:914919.

70. Bestall JC, Paul EA, Garrod R, Garnham R, Jones PW, Wedzicha JA. Usefulness of the Medical Research Council (MRC) dyspnoea scale as a measure of disability in patients with chronic obstructive pulmonary disease. Thorax 1999;54:581-586.

71. Pierson DJ. Clinical practice guidelines for chronic obstructive pulmonary disease: a review and comparison of current resources. Respir Care 2006;51:277-288.

72. Institute of Medicine. Improving the 21st-Centurey health care system; in Institute of Medicine, (ed): Crossing the quality Chiasm. Washington, DC 20418, National Academy Press, 2011, pp 39-60.

73. Jaques $\mathrm{H}$. Putting patients at the heart of quality. BMJ 2012;344:e3164.

74. Vanhaecht K, Panella M, Van Zelm R, Sermeus W. Is there a future for care pathways? Five pieces to the puzzle. Intl J Care Pathw 2009;13.

75. Fervers B, Carretier J, Bataillard A. Clinical practice guidelines. J Visc Surg 2010;147:e341-e349.

76. Cabana MD, Rand CS, Powe NR, Wu AW, Wilson MH, Abboud PA, Rubin HR: Why don't physicians follow clinical practice guidelines? A framework for improvement. JAMA 1999;282:1458-1465.

77. Pierson DJ. Translating evidence into practice. Respir Care 2009;54:1386-1401.

78. Dixon-Woods M, Bosk CL, Aveling EL, Goeschel CA, Pronovost PJ. Explaining Michigan: developing an ex post theory of a quality improvement program. Milbank Q 2011;89:167205.

79. Panella M, Marchisio S, Brambilla R, Di SF. A cluster randomized trial to asses the effect of clincal pathways for patients with stroke. BMC Med 2012;10:71 
Appendix 1. Set of 38 key interventions for in-hospital management of COPD exacerbations

\section{DIAGNOSTIC ASSESSMENT}

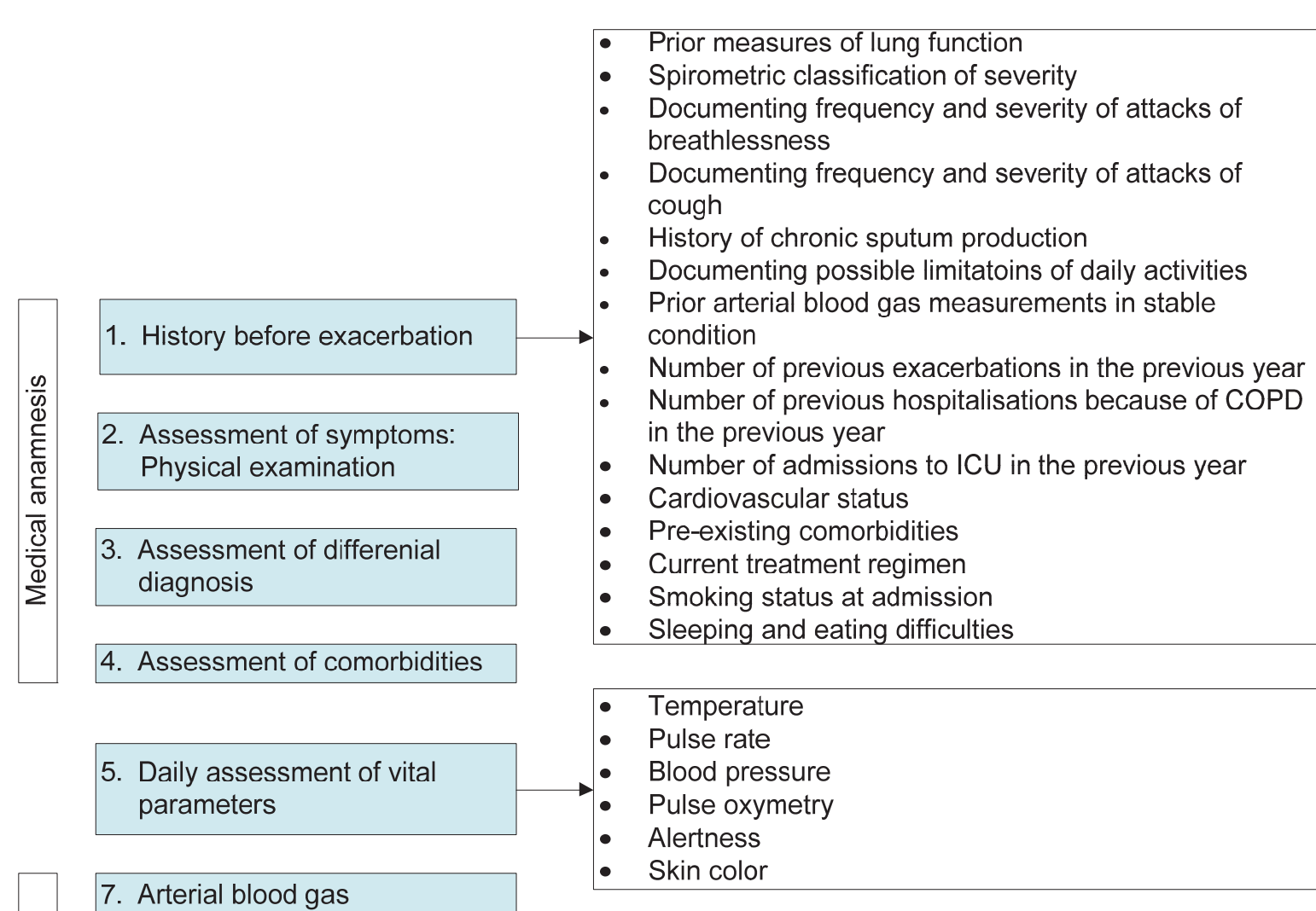

\section{Chest X-ray}

\section{Electrocardiogram}

\section{Blood examination}

6. Glucose monitoring

11. Sputum culture and antibiogram

12. Spirometry

\section{1-yearly CT Thorax}

14. 1-yearly Echo cardio

15. Admission of ICU if exacerbation is life treathening
- Hemaetology

- Biochemical tests (i.e. blood glucose monitoring)

- Theophylline level in patients on theophylline therapy at admission 


\section{PHARMACOLOGICAL MANAGEMENT}

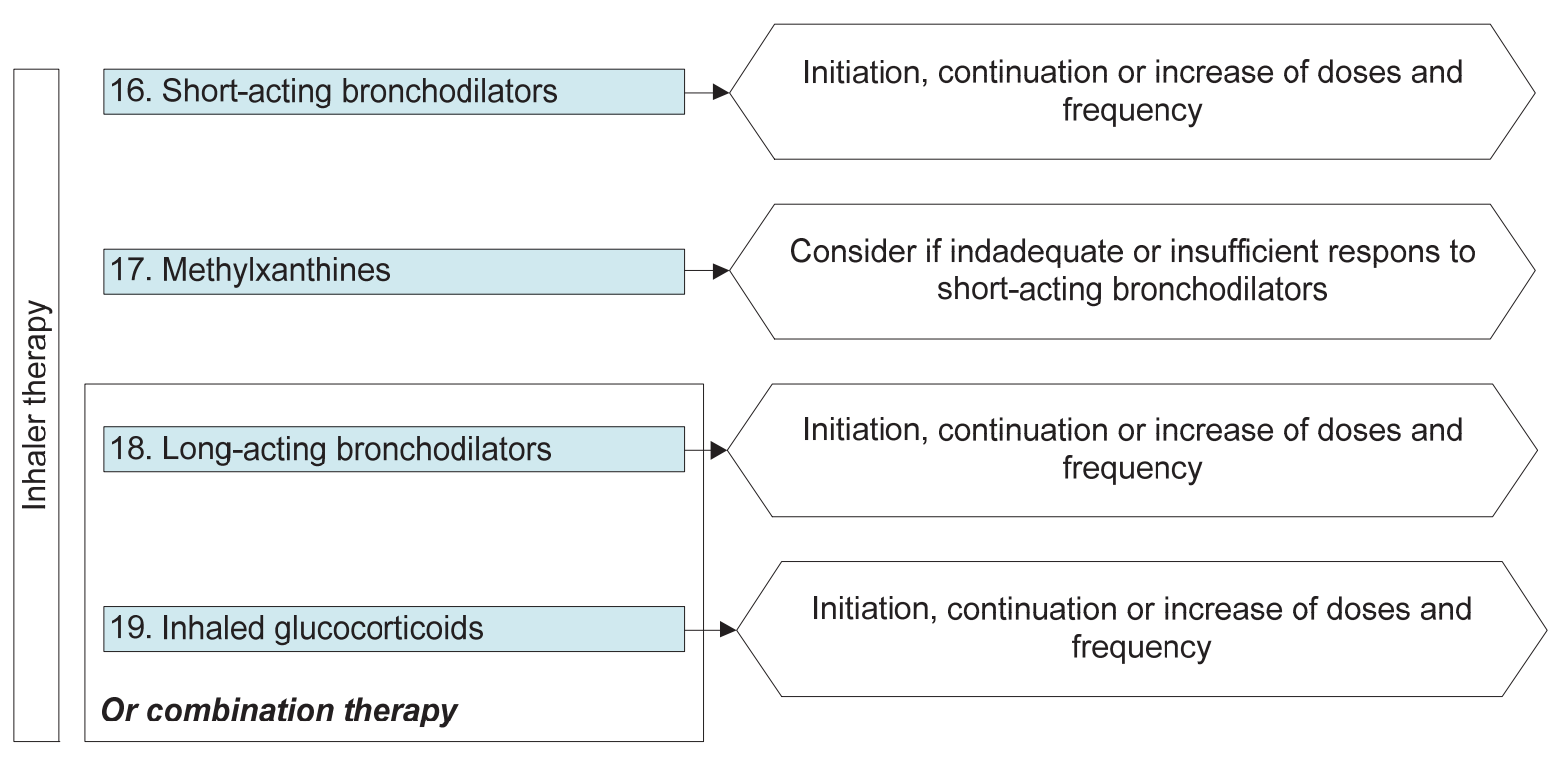

20. Oral prednisolone $30-40 \mathrm{mg}$ during 7-14 days

Indication:

- Patients with increased sputum purulence, and also show increased dyspnoea and or increased sputum volume

21. Antibiotics if indicated

- Patients who are critically ill and who need mechanical support

- Consolidation on a chest radiograph

- Clinical signs of pneumonia 


\section{NON-PHARMACOLOGICAL MANAGEMENT}

\section{Controlled oxygen therapy in patients} hypoxemic during admission

23. Assisted ventilation if indicated

24. Smoking cessation advice in active smokers

25. Patient education: COPD \& self management

26. Patient education: Inhaler therapy

27. Patient education: Home oxygen therapy

28. Physiotherapy

29. Pulmonary rehabilitation

- Training in activities of daily life

- Positioning

- Chest Physiotherapy: airway clearance

- Breathing techniques

- Identification for pulmonary rehabilitation Referral to pulmonary rehabilitatoin

30. Screening and updating of vaccinational status: influenza; pneumococcus

31. Nutritional status

32. Deep venous thrombosis prophylaxis

33. Fluid balance

34. Treatment of co-morbid conditions

35. Assessment and management of anxiety and depression

36. Arterial blood gas measurement prior to discharge in patients hypoxemic during exacerbation

37. Prescription of home oxygen therapy in patients who remain hypoxemic at discharge from the ward

\section{Discharge management}

Nature of COPD

treatment of exacerbations

Self management strategies

Strategies for minimizing dyspnoea
- Assessment:

$\square$ BMI

$\square$ Weight loss

- Dietician:

$\square$ Maltnutrition: nutritional supplement; advice

$\square$ Overweight: advice

- Monitoring of fluid balance

Fluid administration in dehydrated patients

- Assessment of medical discharge criteria

- Assessment and management of home situation

- Oral information and discharge letter regarding prescribed home therapy and follow-up appointment

- Arrangement of follow-up appointment 4-6 weeks after discharge

$\square$ The patient's ability to cope at home

$\square$ Measurement of FEV1

$\square$ Re-assessment of inhaler technique and understanding treatment regime

$\square$ In severe COPD: need for LTOT and/or home nebuliser usage

$\square$ Advice on smoking cessation as necessary

$\square$ Arterial blood gas measurement:

- In the following three months in patients hypoxemic during a COPD exacerbation

- After discharge with LTOT

- Information letter for general practitioner

- Discharge checklist 


\section{Chapter 6:}

\section{Impact of a care pathway for COPD exacerbation: rationale and design of a cluster randomised controlled trial}

This chapter is published and reproduced with the kind permission of the editor:

Vanhaecht K, Sermeus W, Peers J, Lodewijckx C, Deneckere S, Leigheb F, Decramer M, Panella M, for the EQCP study group. The impact of care pathways for exacerbation of chronic obstructive pulmonary disease: Rationale and design of a cluster randomised controlled trial (NCT00962468). Trials 2010,11:111 doi:10.1186/1745-6215-11-111.

This chapter is not identical to the original publication in the journal Trials. References to newly published papers related to the study protocol were added. Additional new details obtained as the study was being conducted were included in the following sections: Sample size, The complex intervention, Measurements, and Data collection. 


\section{Abstract}

Background: Hospital treatment of chronic obstructive pulmonary disease (COPD) frequently does not follow published evidence. This lack of adherence can contribute to the high morbidity, mortality, and readmissions rate.

Aim: The European Quality of Care Pathway (EQCP) study on acute exacerbations of COPD (NTC00962468) was undertaken to determine how care pathways as complex interventions for hospital treatment of COPD affect care variability, adherence to evidence-based key interventions, and clinical outcomes. This chapter presents the rationale and design of the EQCP study.

Methods: An international cluster randomised controlled trial (CRCT) will be performed in Belgium, Italy, Ireland, and Portugal. Power analysis showed that a sample of 40 hospital teams and 398 patients are required for the study. In the control arm of the study, usual care will be provided. The experimental teams will implement a care pathway as a complex intervention. This intervention will include three active components: a formative evaluation of the quality and organisation of care, a set of evidence-based key interventions, and support for the development and implementation of the care pathway. The main outcome will be 6month readmission rate. As a secondary endpoint, a set of clinical outcome and performance indicators (including care process evaluation and team functioning indicators) will be measured in both groups.

Discussion: The EQCP study is the first international CRCT on care pathways. The EQCP project is designed as both a research study and a quality improvement project and will include a realistic evaluation framework and process analysis to further understand why and when care pathways can best work.

Trial Registration number: NCT00962468 


\section{Background}

Healthcare is changing towards more patient-focussed care. The organisation of the care process related to quality, efficiency, and accessibility is one of the main areas of interest in the next years for clinicians, healthcare managers, and policy makers. A main method to (re)organise a care process is the development and implementation of a care pathway. Care pathways, also known as clinical pathways or critical pathways, are used worldwide for a variety of patient groups [1-7]. A care pathway is defined as a complex intervention for the mutual decision making and organisation of predictable care for a well-defined group of patients during a well-defined period. Defining characteristics of pathways includes an explicit statement of the goals and key elements of care based on evidence, best practice, and patient expectations; facilitation of communication and coordination of roles; sequencing activities of the multidisciplinary care team, patients, and their relatives; documentation, monitoring, and evaluation of variances and outcomes; and identification of relevant resources [8-10].

A care pathway is explicitly defined as a 'complex intervention' [8-12]. Complex interventions in healthcare, whether therapeutic or preventive, comprise a number of interacting components that seem essential to the proper functioning of the intervention, although the effective 'active component' of the intervention is difficult to specify. When considering a spectrum of low to high complexity, developing a drug would be at the low end of the complexity spectrum, while the evaluation of the effect of a stroke unit would be at the high end of the spectrum. The greater the difficulty in defining precisely what the 'active component' of an intervention is and how these component(s) relate to each other, the greater the likelihood that one is dealing with a complex intervention. Pathways in the realm of stroke units seem to be at the higher end of the complexity spectrum [13-16]. Active ingredients of a care pathway complex intervention might be the level of multidisciplinary teamwork, the integration of a package of evidence-based key interventions, and the active follow-up of the care process [6].

A recent Cochrane review concludes that clinical pathways reduce in-hospital complications and improve documentation without negatively affecting length of stay (LOS) and hospital costs [17]. The effects, however, are still quite small in comparison to what we might expect theoretically. One possible reason is the high variability in effect from one organisation to another, which seems to stress the idea that context factors might be extremely important [9;18-20]. These context factors are not considered in these metaanalyses. An indicator of context influence is the heterogeneity of meta-analyses, which seem to be quite high in the Rotter meta-analysis paper [17]. Completion of large multicentre trials that include information on the mechanisms used and the context of the involved 
organisations will be necessary to fully understand why and when pathways lead to their effect $[9 ; 16 ; 21]$.

To evaluate pathway effectiveness, the European Pathway Association (E-P-A), an international not-for-profit association, launched the European Quality of Care Pathways (EQCP) study on exacerbation of chronic obstructive pulmonary disease (COPD) [21]. COPD exacerbations are a leading cause of acute hospital admissions worldwide [22-24]. Patients with COPD exacerbations need multidisciplinary care. Moreover, the coordination of the care process among multiple caregivers is complex [25;26]. Thirty-five percent of COPD patients are admitted because of acute exacerbations within one year, and up to $40 \%$ of admitted patients have two or more readmissions a year [22-24]. A systematic review about in-hospital management of COPD exacerbations showed that implementation of care processes recommended by widely accepted guidelines is very poor and show high variance, especially for performance of non-pharmacological interventions [27]. Also, Decramer et al. observed several important deviations from international guidelines in the management of COPD by pulmonologists and general practitioners [28].

Up to now, four non-randomised trials on the impact of a care pathway for inpatient management of COPD exacerbations have been published [29]. The studies were conducted between 2000 and 2001, and the methodology was rather weak. However, there are some indications in these studies suggesting that a COPD exacerbation care pathway improves performance with regard to diagnostic assessment and use of standing orders, and that it may reduce LOS and the number of hospitalisations [29].

\section{Objectives}

The primary goal of the EQCP study on COPD exacerbations is to evaluate care pathway effectiveness in acute hospitals. A secondary goal is to understand how and under which circumstances the implementation of a care pathway for COPD exacerbations is successful.

\section{Methods}

\section{The project}

The EQCP study is an international multicentre research project launched by the E-P-A (www.E-P-A.org) [21]. The E-P-A has been collaborating with the Centre for Health Services and Nursing Research of the Faculty of Medicine of the Catholic University Leuven (Belgium) and the School of Public Health of the Amedeo Avogadro University of Eastern Piedmont (Italy) for the scientific lead in the this study. The study is conducted in four countries: Belgium, Ireland, Italy, and Portugal. In each country, a research centre coordinates the project in that country based on the agreed international protocol. In Belgium, the lead 
coordinating centre is the Centre for Health Services and Nursing Research of the Faculty of Medicine of the Catholic University Leuven. For Ireland, the lead centre is the Health Service Executive in Dublin. In Italy, the School of Public Health of the Amedeo Avogadro University of Eastern Piedmont coordinates the project with support from ARESS Piedmonte. In Portugal, the lead coordinating centre is the National School of Public Health in Lisbon. In each of the four countries hospitals will be selected by E-P-A in close cooperation with a national coordinator. In every participating hospital a pathway facilitator is appointed as a local facilitator for implementing the care pathway. In each country except Belgium, the E-PA team trains the pathway facilitator in implementing care pathways. In Belgium, hospitals were selected from the members of the Belgian-Dutch Clinical Pathway Network (BDCPN), and all pathway facilitators were trained beforehand within the network [21].

\section{Study design}

The complex intervention and the trial are designed according to the 'Framework for development and evaluation of complex interventions' [15;16]. This study is a phase 3 study that includes a cluster randomised controlled trial (cRCT) [15;16;30]. In cRCTs, organisations, rather than individuals, are randomised to intervention and control groups, and outcomes are measured on individuals within the clusters [30]. Care pathways induce change at different levels of the organisation (i.e. patient, team, hospital, etc.). To deal with these multilevel effects when evaluating a care pathway, it will be appropriate to use a CRCT, implying randomisation occurs at the highest level of the intervention (i.e. randomise the team rather than the practitioners or patients) [12;16;30-33]. In addition, if the effect of a care pathway would be explored in a single organisation, the intervention given to the individuals in the experimental group may also inadvertently affect individuals of the control group within that organisation (i.e. contamination) [30;33].

In this study, each cluster will consist of a hospital where patients are hospitalized for COPD exacerbation and cared for by a specific multidisciplinary team [21]. Hospitals will be randomised to an experimental group, where a care pathway will be implemented, and to a control group, where usual care will be delivered (no intervention). To ensure that hospitals in both arms are balanced, we will use stratified randomisation based on country level, hospital type (teaching versus non-teaching) and hospital size ( $<600$ and $\geq 600$ beds) [34;35]. Additionally, several organisational factors will be explored: availability of an early discharge scheme, presence of a formal pulmonary rehabilitation programme, availability of noninvasive ventilation, and volume of patients annually treated for COPD exacerbations [34;35]. These variables will be treated as covariates in the data analysis.

Measurements will include follow-up of care processes and clinical outcomes (Figure 1), and results of the intervention and control groups will be compared to evaluate whether the 
implementation of a care pathway leads to better compliance to care processes and improved clinical outcomes.

Figure 1. Study design of the European Quality of Care Pathways (EQCP) study on COPD exacerbation

\section{Cluster Randomised Controlled Trial (cRCT)}

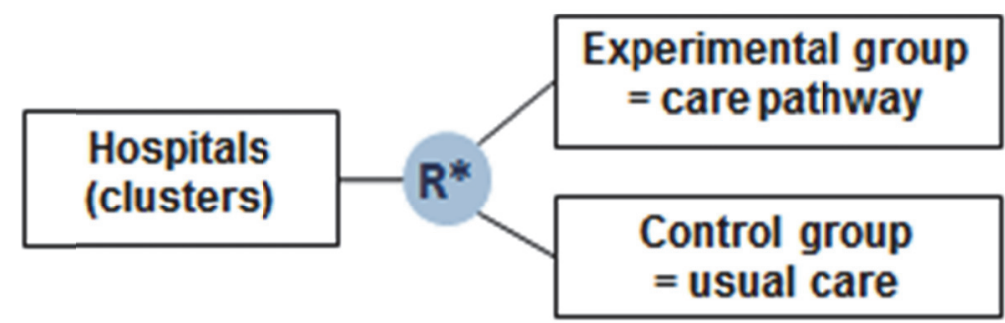

R Randomisation

* Stratification: country, type, size

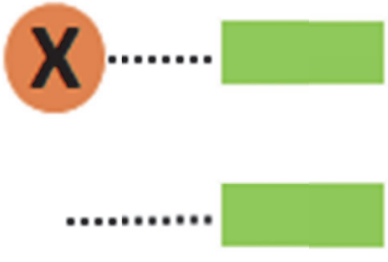

Measurements on process and outcome indicators

\section{Inclusion-exclusion criteria}

Organisations can be included if (i) they provide written agreement to participate in the study; and (ii) if they agree not to develop and implement a pathway for COPD within the time frame of the study when randomised into the control group.

In every hospital, 20 consecutive patients need to be followed up. Patients can be included in the study if (i) admitted with COPD exacerbation as the primary diagnosis, (ii) hospitalised for at least 48 hours, (iii) admitted in a ward where COPD exacerbations are usually treated, (iv) able to understand and read the native language, and (v) written informed consent is given. A patient can be included in the study only once, specifically at his or her first admission during the study period. Patients are excluded if one of the following criteria is present: (i) already included in another study of which the measurements could influence the measurements or outcomes of the EQCP study; and/or (ii) need for invasive positive pressure ventilation (IPPV) at admission into the hospital.

Patients initially included in the study could drop out for three reasons: (i) if patient voluntarily decides to withdraw from the study, (ii) if patient is incorrectly diagnosed with a COPD exacerbation, and (iii) if diagnosis of COPD exacerbation remains unconfirmed. If the patient dies or is transferred to another hospital, the data collection ceases for that particular patient, but the patient remains included in the study and so is part of the total sample of 20 patients in the particular hospital. Hospitals will be asked to keep a logbook for included 
patients, to keep a summary of the included patients, and especially to be able to look for additional information when necessary and to check why patients dropped out or were not followed up during the whole study. Secondly, they will be asked to keep a logbook for excluded patients in order to check for selection bias.

\section{Study sample}

An important consequence of a cluster randomised design is that, unlike individually randomised trials, the outcome for each participant cannot be assumed to be independent of any other participant, since those within a cluster are more likely to have similar outcomes. Thus, the statistical power of a cRCT may be substantially less than that of a similar-sized, individually randomised trial [30]. In order to take into account the cluster effect, the variance term in standard statistical formulae for sample size calculation needs to be increased by the 'design effect', also called the 'inflation factor'. In other words, the design effect is a measure for the number of extra patients needed to deal with this cluster effect. The design effect is calculated based on the intra-cluster correlation coefficient (ICC) [36-38], which accounts for the relatedness of clustered data by comparing the variance within clusters with the variance between clusters. The ICC needs to be estimated from previous studies that used similarsized clusters containing similar types of individuals and used the same outcome [36-38]. The dependency in outcomes also implies that increasing the number of clusters offers more power than does increasing the number of individuals per cluster. However, this adjustment is sometimes very difficult, considering the logistical and economic implications when performing a cRCT. Furthermore, cRCTs with fewer than five clusters per arm are inadvisable, since parametric tests may be unreliable with such small numbers and since nonparametric tests require at least four to six clusters per arm to achieve statistical significance [30].

Sample size calculation in cRCTs is based on the improvement in the main outcome parameters [36;38]. The selection of main outcomes for the EQCP study is based on three parameters: frequency of use in the literature, opinions of experts, and timing of the research with regard to organisational factors (sustainability of the design, time to include patients). Based on these criteria, 6-month readmission rate was identified as the main study outcome for in-hospital management of COPD exacerbations [39;40]. Other important parameters are LOS, 30-day readmission, and 6-month mortality [39;40]. Achieving a power of $80 \%$ and a significant $\alpha$ of 0.05 , requires 296 patients per arm to observe a $10 \%$ reduction in readmission rates of $41 \%$ to $30 \%$ [39;40]. After adjustment for the cluster design, based on two previous cRCTs by Panella et al. (ICC: 0.018 ; Design effect: $1.342 ; n=20$ ) [12;31;41], the effective sample size is increased to 398 patients per arm. This means that, with our criterion of 20 consecutive admitted patients in each unit, 20 hospitals are required to be included in 
both the intervention and control group. As four countries are involved in the study, each country had to enrol at least 10 hospitals, with randomisation into five intervention cases and five control cases.

Between September 2008 (Belgium) and September 2009 (Ireland, Italy, and Portugal), 117 hospitals out of the four countries were invited to participate in the study (Figure 2). Seventy-one of them consented. After assessment of eligibility, 65 hospitals were included in the study (Belgium: $n=15$; Ireland: $n=14$; Italy: $N=12$; Portugal: $N=24$ ) (Figure 2). The participating hospitals in Belgium were all members of the BDCPN, which explains the unusually high number of hospitals in Belgium excluded (i.e. already having a COPD care pathway in operation). Based on stratified randomisation according to country level, hospital type (teaching vs. non-teaching), and of hospital size ( $<600$ and $\geq 600$ beds) [34;35], in total 33 hospitals were enrolled in the intervention group and 32 hospitals in the control group (Figure 2). As a consequence, up to 600 potential patients will be included in each arm.

\section{The complex intervention: care pathway implementation in the experimental arm}

The care pathway will include three active components. (i) A formative evaluation on the quality and organisation of the care process before care pathway implementation. A clinical audit, including follow-up of 24 process indicators in 20 patients (Chapter 5 , Table 2), will be performed 6 months before developing the care pathway and during a 2-3 month period. During a workshop, a formative feedback report, based on the results of the clinical audit, will be provided to the teams describing the relative performance of every team against the evidence-based protocol and against the performance of all other teams in the study. This feedback will help the teams in understanding their bottlenecks and their actual overall organisation of the care process.

(ii) Integration of a set of evidence-based key interventions on in-hospital management of COPD exacerbations (Chapter 5, Appendix 1). A set of 38 evidence-based key interventions will be provided to the multidisciplinary team of all participating hospitals, and a workshop on the content of the key interventions will be organised. This set of key interventions was developed based on (i) the literature, (ii) an international Delphi study [42], and (iii) a consensus meeting with a multidisciplinary expert panel, including a medical doctor, a physiotherapist, and a clinical nurse specialist-each with extensive clinical and scientific expertise in COPD—and three experts in patient care management (Chapter 5 , Appendix 1).

(iii) Training on care pathway development and implementation (Plan Do Study Act [PDSA] cycle and teamwork). The pathway facilitator of each hospital is trained to develop and implement a care pathway, based on the findings of the formative evaluation of the care process and the set of evidence-based key interventions. Pathway facilitators use a care 
pathway implementation protocol based on the Deming-PDSA cycle [43]. Meetings with the pathway facilitators are organised to present and discuss the feedback reports and the set of evidence-based key interventions, and to discuss actual bottlenecks in implementing the care pathway. Change is supported by providing the possibility for participants to exchange best practices. During these meetings local clinical champions and team change experts support and stimulate the pathway facilitators to effective knowledge sharing processes.

Figure 2. Flow diagram: hospital recruitment and randomisation

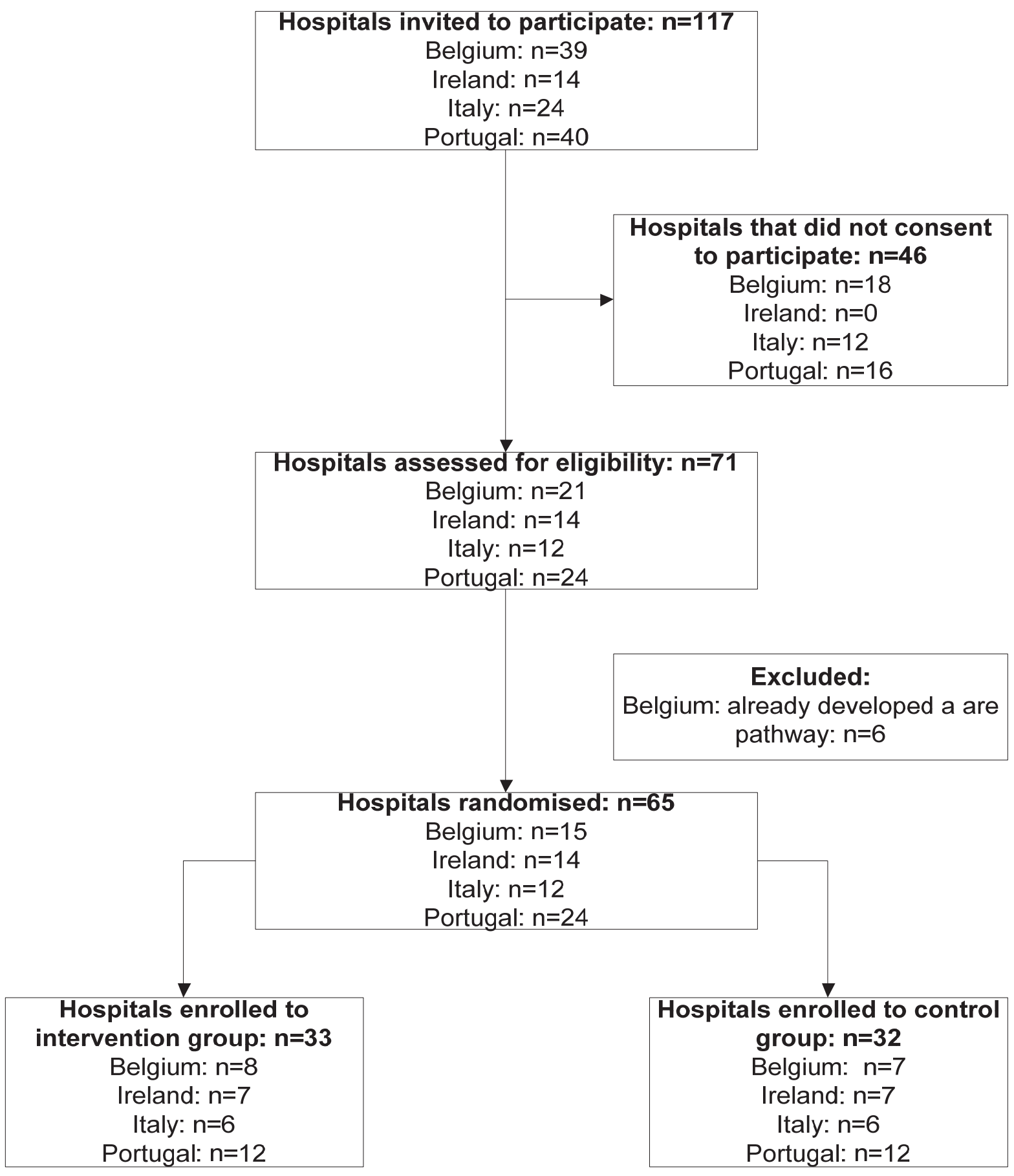




\section{The control group}

In the control group, the complex intervention will not be implemented, and so the control hospitals agree not to change their actual organisation of the care process and not to develop a care pathway during the study period. The team members provide care in the same way as they did before the start of the study. This is referred to as usual care. The hospitals included in the control group will be offered the opportunity to develop a care pathway one year later, based on the protocol and experience gained in the experimental group. By this means, the design incorporated some characteristics of a step wedge design in which the implementation of the intervention is spread over time.

\section{Measurements}

To measure compliance to care processes and performance of clinical outcomes, a set of 24 process and 15 outcome indicators will be followed up. These indicators were developed on the basis of (i) an extensive literature review, (ii) an international Delphi survey [42], and (iii) consensus meetings with a multidisciplinary expert panel that included a pulmonologist, a physiotherapist, a clinical nurse specialist in COPD, and three experts in patient care management (Chapter 5, Table 2). The primary outcome measure in the EQCP study is 6month readmission. Main secondary outcome measures included 30-day readmission, 30day mortality, 6-month mortality, LOS, and quality of life, (Chapter 5, Table 3). Measurements on the quality of the clinical care processes include monitoring the performance of diagnostic, pharmacological, and non-pharmacological processes during hospital stay and at discharge (Chapter 5, Table 3). Finally, 15 baseline variables will be measured, including socioeconomic, demographic, and COPD-specific data (Chapter 5, Table 3). Process and outcome indicators were translated into objective measurements by the multidisciplinary expert panel, according to the guidelines of the Agency for Healthcare Research and Quality (www.qualitymeasures.ahrq.gov) and The Joint Commission (www.jointcommission.org) (Chapter 5, Figures 4 and 5).

To further understand why pathways are effective, information on the context of the organisation is important. Therefore, in a parallel study on teamwork (included in another $\mathrm{PhD}$ dissertation), a set of both generic and COPD-specific context indicators and team structure indicators will followed up [21;44;45].

\section{Data collection}

Data collection will occur at three time points through (i) structured interviews performed by a team member at discharge, (ii) patient questionnaires to be completed at discharge and 30 days after discharge from the ward, and (iii) two structured telephone interviews performed by the study coordinator 30 days and 6 months after discharge from the ward. 
Additionally, the study coordinator together with a clinician will perform a patient record analysis after inclusion of the 20 patients. To carry out these analyses, an external researcher will be involved to ensure that an objective 'snapshot' of the patient record will be obtained. Should a team member carry out the patient record analyses, a high risk for bias would be present, as the member might also report care activities that were not documented in the patient record as 'performed', but of which the caregiver is convinced that they were being performed in that particular patient. In our opinion, if performance of a care activity or the results of performing an activity (for instance, lab results or understanding after education on inhaler therapy) are not documented in the patient record, this performance and these results are not detectable by the other team members caring for this patient. As a consequence, they will not know if the particular care activity was carried out or not, and if the intervention was effective or not. In such circumstances, the results cannot be used to optimise further care for the patient. So in conclusion, non-documentation of performance of a care activity or related results was interpreted as non-optimal performance in our study. In addition, team members could provide a 'better snapshot' of their care in the context of 'social desirability', which is also avoided by assigning an external researcher to the patient record analyses. Also, it was recommended that the external researchers ask a clinician for assistance when analysing the first patient record to ensure that all available data in the patient record will be captured.

Overall, in order to minimise risk for missing data, we limited the amount of data collected by the patient questionnaire at 30 days to those data that could not be collected in another way. Thus, most data collected through the patient record analyses and questionnaires will be completed by the team at discharge. All outcomes will be measured using validated instruments available in literature.

The data collection forms were printed and classified per collection time point for 20 patients, and delivered into two binders to each organisation. All data will be collected centrally in every hospital, and then will be provided to the national coordinators of all participant countries. Data will be entered into a central database at the Catholic University Leuven. 


\section{Registration and Ethical approval}

The study is registered as a CRCT at clinicaltrials.gov (identifier: NCT00962468). The ethical approval will be country specific, but overall ethical approval will be maintained on three levels: (i) ethical approval by the ethical committee of the coordinating centre at the country level; (ii) ethical approval with regard to participation in the intervention at the cluster level, namely by the ethical committee of each of the participating hospitals; and (iii) individual informed consent will be sought from the patients with regard to the access to the patient record and participation in surveys. As indicated by the Medical Research Council, patients' consent to participate in the study is not possible, because randomisation occurs at the hospital level and not at the patient level [30]. Moreover, the aim of the study is to improve adherence to evidence-based care through clinical pathways in the intervention group. In the control group, no intervention will be implemented and, thus, patients will receive usual care. Therefore, being included in the experimental or control group should not imply any risk for the patients.

Approval from the ethical committee of the coordinating centre at Leuven University was obtained (identifier: ML5617), and the proposal was also approved by the ethical committees of all participating hospitals.

\section{Discussion}

The EQCP study is the first international CRCT on the effect of care pathways [21]. Within this study, a cRCT design is combined with a realistic evaluation approach [46]. In this way, any differences between the experimental and control arms can be analysed, but also the process evaluations within the experimental arm itself can be followed up and evaluated [47]. As suggested by Berwick in 2008, it is not only important to understand whether an intervention is effective, but it is also important to understand why and under what circumstances it works [19]. The approach in the EQCP study will allow us to analyse whether pathways work and also will provide information on when and how they work [21]. Within this international trial, three active ingredients define the complex intervention: feedback on the actual situation, information on the evidence-based key interventions, and implementation and design process.

Hawe and colleagues argued that the crucial point in the evaluation of complex interventions lies in what is standardised: In complex interventions, the function and process of the intervention should be standardised, not only the components themselves [48]. This argument is important for pathway research and was previously addressed by Panella et al. [11]. In pathway research, the pathway process or quality improvement cycle that is run 
through is part of the intervention. In that way the improvement and implementation process is included as one of the basic active ingredients.

One challenge in carrying out multicentre trials on pathways, studying quality improvement methods in general, or in comparing pathways from or between different organisations, is to understand the role of context. Pawson and Tilley defined an action as causal only if its outcome is triggered by a mechanism acting in a context (context + mechanism = outcome) [46]. They argued that programmes work (i.e. have good outcomes) only insofar as they introduce the appropriate ideas and opportunities (the mechanism) to groups in the appropriate social and cultural conditions (the context) [19;46]. This realistic evaluation paradigm has already been used in pathway research [7] and was recently suggested by Berwick in a publication on the science of improvement [19]. For pathways, the mechanism will need to be based on the basic active ingredients described above. However, the fine-tuning of the intervention will be based on the actual bottlenecks and on the context of the organisation and multidisciplinary team involved. Therefore, in the present international CRCT on pathways, also a set of team indicators and organisational factors will be measured [44]. The process and outcome indicators will provide data to help us understand whether pathways work, but the team indicators will help us understand why and how they work $[21 ; 44 ; 45]$.

With this study, E-P-A will be able to influence health professionals and hospital managers in actively improving the quality and efficiency of care [21]. The teams receive support in the reorganisation of the COPD care processes and can later use this implementation knowledge in other care processes. Teams will receive feedback on their own organisation, including benchmark data in comparison with other international teams. In this way the design of the EQCP project is both a research study and a quality improvement project.

The following chapters (Chapters 7 and 8 , respectively) describe (i) the preliminary results of the EQCP study, including the results of the Belgian EQCP study, and (ii) an implementation analyses with regard to the second component of the complex intervention, 'integration of a set of evidence-based key interventions'.

\section{Acknowledgements}

We gratefully acknowledge Pfizer Belgium, Pfizer Italy, Pfizer Ireland, and Pfizer Portugal for the unrestricted educational grants for this research project, permitting E-P-A to support the EQCP study in all scientific and logistical independence. The autonomy of E-P-A and the involved academic institutions with regard to all intellectual property related to the results and methodology is guaranteed. We further thank Map of Medicine ${ }^{\circledR}$ for providing us evidence- 
based information that assisted us in developing the intervention. We thank all members of the EQCP study group for their help and support. The EQCP study group consists of the following researchers: Belgium: Kris Vanhaecht, Walter Sermeus, Jan Peers, Cathy Lodewijckx, Svin Deneckere, Martin Euwema, Marc Decramer, and Steven Boonen; Italy: Massimiliano Panella, Fabrizio Leigheb, Wilma Cittaro, and Domenico Tangolo; Ireland: William Reddy and Antoinette Doocey; Portugal: Paulo Alexandre Faria Boto and Rita Veloso Mendez. 


\section{References}

1 Bower K. Clinical pathways: 12 lessons learned over 25 years of experience. Intl J Care Pathw 2009;13:78-81.

2 Campbell H, Hotchkiss R, Bradshaw N, Porteous M. Integrated care pathways. BMJ 1998;316:133-137.

3 Panella M, Marchisio S, Di SF. Reducing clinical variations with clinical pathways: do pathways work? Int J Qual Health Care 2003;15:509-521.

4 Pearson SD, Goulart-Fisher D, Lee TH. Critical pathways as a strategy for improving care: problems and potential. Ann Intern Med 1995;123:941-948.

5 Trowbridge R, Weingarten S. Making health care safer, a critical analysis of patient safety practices.; 2001.

6 Vanhaecht K, Bollman M, Bower K, Gallagher C, Gardine A, Guezo J, Jansen U, Massoud R, Moody K, Sermeus W, Van Zelm R, Whittle C, Yazbeck A, Zander K, Massimilian P. Prevalence and use of clinal pathways in 23 countries - an internation survey by the European Pathway Association (www.E-P-A-.org). Intl J Care Pathw 2006;10:28-34.

7 Vanhaecht K, De Witte K, Sermeus W. The impact of clinical pathways on the organisation of care processes. Leuven, ACCO, 2007.

8 Vanhaecht K, De Witte K, Sermeus W. The Care Process Organisation Triangle: A framework to better understand how clinical pathways work. Intl J Care Pathw 2007;11:1-8.

9 Vanhaecht K. Comment on: What is a clinical pathway? Development of a definition to inform the debate. BMC Medicine 2010;8.

10 Panella M, Vanhaecht K. Is there still need for confusion about pathways? Intl J Care Pathw 2010;14:1-3.

11 Panella M, Brambilla R, Marchisio S, Di SF. Reducing Stroke In-Hospital Mortality: Organized Care Is a Complex Intervention. Stroke 2008.

12 Panella M, Marchisio S, Demarchi ML, Manzoli L, Di SF. Reduced in-hospital mortality for heart failure with clinical pathways: the results of a cluster randomised controlled trial. Qual Saf Health Care 2009;18:369-373.

13 Campbell M, Fitzpatrick R, Haines A, Kinmonth AL, Sandercock P, Spiegelhalter D, Tyrer $P$. Framework for design and evaluation of complex interventions to improve health. BMJ 2000;321:694-696.

14 Craig P, Dieppe P, Macintyre S, Michie S, Nazareth I, Petticrew M: Developing and evaluating complex interventions: the new Medical Research Council guidance. BMJ 2008;337:a1655. 
15 Medical Research Council. A Framework for development and evaluation of RCTs for Complex Interventions to Improve Health; 2000.

[http://www.mrc.ac.uk/Utilities/Documentrecord/index.htm?d=MRC003372]

16 Medical Research Council (2008): Developing and evaluating complex interventions: new guidance, 2008.

[http://www.mrc.ac.uk/Utilities/Documentrecord/index.htm?d=MRC004871]

17 Rotter T, Kinsman L, James E, Machotta A, Gothe H, Willis J, Snow P, Kugler J. Clinical pathways: effects on professional practice, patient outcomes, length of stay and hospital costs. Cochrane Database Syst Rev 2010;3:CD006632.

18 Campbell NC, Murray E, Darbyshire J, Emery J, Farmer A, Griffiths F, Guthrie B, Lester $\mathrm{H}$, Wilson $\mathrm{P}$, Kinmonth $\mathrm{AL}$. Designing and evaluating complex interventions to improve health care. BMJ 2007;334:455-459.

19 Berwick DM. The science of improvement. JAMA 2008;299:1182-1184.

20 Barbieri A, Vanhaecht K, Van HP, Sermeus W, Faggiano F, Marchisio S, Panella M: Effects of clinical pathways in the joint replacement: a meta-analysis. BMC Med 2009;7:32.

21 Vanhaecht K, Sermeus W, Peers J, Deneckere S, Lodewijckx C, Leigheb F, Panella M. The European Quality of Care Pathways (EQCP) Study: history, project managment and approach. Intl J Care Pathw 2010;14:52-56.

22 Cao Z, Ong KC, Eng P, Tan WC, Ng TP. Frequent hospital readmissions for acute exacerbation of COPD and their associated factors. Respirology 2006;11:188-195.

23 Garcia-Aymerich J, Farrero E, Felez MA, Izquierdo J, Marrades RM, Anto JM. Risk factors of readmission to hospital for a COPD exacerbation: a prospective study. Thorax 2003;58:100-105.

24 Izquierdo JL, Barcina C, Jimenez J, Munoz M, Leal M. Study of the burden on patients with chronic obstructive pulmonary disease. Int J Clin Pract 2009;63:87-97.

25 Kuzma AM, Meli Y, Meldrum C, Jellen P, Butler-Lebair M, Koczen-Doyle D, Rising P, Stavrolakes K, Brogan F. Multidisciplinary care of the patient with chronic obstructive pulmonary disease. Proc Am Thorac Soc 2008;5:567-571.

26 Global Initiative for Chronic Obstructive Lung Disease (GOLD). Global strategy for the diagnosis, management, and prevention of chronic obstructive pulmonary disease, updated 2010. [http://www.goldcopd.org/guidelines-global-strategy-for-diagnosismanagement.html]

27 Lodewijckx C, Sermeus W, Vanhaecht k, Panella M, Deneckere S, Leigheb F, Decramer M: Inhospital management of COPD exacerbations: a systematic review of the literature with regard to adherence to international guidelines. Journal of Evaluation in Clinical Practice 2009;15:1101-1110. 
28 Decramer M, Bartsch P, Pauwels R, Yernault JC. Management of COPD according to guidelines. A national survey among Belgian physicians. Monaldi Arch Chest Dis 2003;59:62-80.

29 Lodewijckx C, Sermeus W, Vanhaecht k, Panella M, Deneckere S, Leigheb F, Decramer M. Impact of care pathways for in-hospital management of COPD exacerbations: a systematic review. Int J Nurs Stud. 2011;48:1445-56.

30 Medical Research Council (MRC): Cluster Randomised Trials: Methodological and ethical considerations. Medical Research Council (MRC) 2002.

[http://open.mrc.gm/Statsdatamgt/stats\&datam_files/MRCguide_cluster.pdf]

31 Panella M, Marchisio S, Barbieri A, Di SF: A cluster randomized trial to assess the impact of clinical pathways for patients with stroke: rationale and design of the Clinical Pathways for Effective and Appropriate Care Study [NCT00673491]. BMC Health Serv Res 2008;8:223.

32 Scales DC, Dainty K, Hales B, Pinto R, Fowler RA, Adhikari NK, Zwarenstein M. A multifaceted intervention for quality improvement in a network of intensive care units: a cluster randomized trial. JAMA 2011;305:363-372.

33 Sermeus W, De Bleser L, Depreitere R, Dewaele K, Vanhaecht k, Vlayen J. An introduction to clinical pathways. In Devriese S, Lambert M, Eyssen M, Van de Sande S, Poelmans J, Van Brabandt H, Sermeus W, Vlayen J, Ramaekers D, (eds): The use of clinical pathways and guidelines to determine physicians' hospital fees prospectively: easier said than done.T. Brussels, Belgian Healthcare Knowledge Centre (KCE). KCE Reports, 2005.Volume 18A. [http:/www.kenniscentrum.fgov.be/nl/publicaties.html]

34 Hosker H, Anstey K, Lowe D, Pearson M, Roberts CM. Variability in the organisation and management of hospital care for COPD exacerbations in the UK. Respir Med 2007;101:754-761.

35 Roberts CM, Barnes S, Lowe D, Pearson MG. Evidence for a link between mortality in acute COPD and hospital type and resources. Thorax 2003;58:947-949.

36 Campbell MK, Mollison J, Grimshaw JM. Cluster trials in implementation research: estimation of intracluster correlation coefficients and sample size. Stat Med 2001;20:391-399.

37 Killip S, Mahfoud Z, Pearce K. What is an intracluster correlation coefficient? Crucial concepts for primary care researchers. Ann Fam Med 2004;2:204-208.

38 Ukoumunne OC, Gulliford MC, Chinn S, Sterne JA, Burney PG. Methods for evaluating area-wide and organisation-based interventions in health and health care: a systematic review. Health Technol Assess 1999;3:iii-92. 
39 Almagro P, Barreiro B, Ochoa de EA, Quintana S, Rodriguez CM, Heredia JL, Garau J. Risk factors for hospital readmission in patients with chronic obstructive pulmonary disease. Respiration 2006;73:311-317.

40 Bratzler DW, Oehlert WH, McAdams LM, Leon J, Jiang H, Piatt D. Management of acute exacerbations of chronic obstructive pulmonary disease in the elderly: physician practices in the community hospital setting. J Okla State Med Assoc 2004;97:227-232.

41 Panella M, Marchisio S, Gardini A, Di SF. A cluster randomized controlled trial of a clinical pathway for hospital treatment of heart failure: study design and population. BMC Health Serv Res 2007;7:179.

42 Lodewijckx C, Sermeus W, Panella M, Deneckere S, Leigheb F, Troosters T, Boto P, Mendeze R, Decramer M, Vanhaecht K. Quality indicators for in-hospital management of exacerbation of chronic obstructive pulmonary disease: results of an international Delphi study. J Adv Nurs. 2012 (Epub ahead of print).

43 Vanhaecht K, Deneckere S, Van Gerven E, Lodewijckx C, Janssens I, Van Zelm R, Boto P, Panella M, Biringer E, Sermeus W. The 7-phase method to design, implement and evaluate care pathways. Intl J Pers Cent Med 2011. In press.

44 Deneckere S, Robyns N, Vanhaecht K, Euwema M, Panella M, Lodewijckx C, Leigheb F, Sermeus W, Study Group. Indicators for Follow-Up of Multidisciplinary Teamwork in Care Processes: Results of an International Expert Panel. Eval Health Prof 2010.

45 Deneckere S, Euwema M, Lodewijckx C, Panella M, Sermeus W, Vanhaecht K. The European quality of care pathways (EQCP) study on the impact of care pathways on interprofessional teamwork in an acute hospital setting: study protocol for a cluster randomised controlled trial and evaluation of implementation processes. Implement Sci 2012;7:47.

46 Pawson R, Tilly N. Realistic evaluation. London, SAGE Publications, 1997.

47 Oakley A, Strange V, Bonell C, Allen E, Stephenson J. Process evaluation in randomised controlled trials of complex interventions. BMJ 2006;332:413-416.

48 Hawe P, Shiell A, Riley T. Complex interventions: how "out of control" can a randomised controlled trial be? BMJ 2004;328:1561-1563. 
Chapter 7:

Impact of a care pathway for COPD exacerbation: preliminary results of the European Quality of Care Pathways (EQCP) Study 


\section{Context}

Chapter 6 presented the design and rationale for the European Quality of Care Pathways (EQCP) study on COPD exacerbations. This study is conducted in four countries (Belgium, Ireland, Italy, and Portugal) with two aims: (i) to evaluate whether the implementation of a care pathway, compared with usual care, improves compliance to evidence-based care processes and performance of clinical outcomes for patients hospitalised with COPD exacerbations; and (ii) to study why and under what circumstances care pathways work.

This PhD dissertation research was integrated into the EQCP study and focusses on the first study aim: the impact of care pathways for in-hospital management of COPD exacerbations on care processes and clinical outcomes. The Belgium component of the EQCP study is one year ahead of the other countries and is also considered to be a pilot test. Because of timing and feasibility of the $\mathrm{PhD}$ dissertation, only the results of the Belgium EQCP study are included in the results section and are described in the present chapter. Final results based on the data of all four countries are expected to be analysed in autumn 2013. These results will be disseminated by the EQCP study group via publications and conference proceedings in 2013 and 2014.

\section{Belgian sample size and interpretation of results}

\section{Belgian sample size}

Of the 12 hospitals included in the Belgium component of the EQCP study, 7 hospitals were randomly assigned to the experimental group and 5 to the control group, resulting in a final sample size of 136 patients in the experimental group and 100 patients in the control group (cf. results section). Power analyses show that 400 patients should be included in each arm to have a statistical power of $80 \%$ and a significant $\alpha$ of 0.05 (Chapter 6) [1]. As the current sample size of the Belgian study is too small to achieve this level of statistical power, these data were analysed as first phase results. These results will not be published as a separate paper in a peer-reviewed journal. A final analysis will be performed on the combined data of the four participating countries at the end of the EQCP study, as this final sample size will be sufficient to guarantee a statistical power of $80 \%$ [1].

\section{Interpretation of results}

Because of low statistical power, the chance for detecting statistically significant results is reduced [2-4]. However, with regard to process indicators, even non-significant results provide valid information regarding quality of care and differences in both groups. Indeed, clinical practice guidelines, which are very congruent and continuously updated [5-8], recommend unambiguously that the evaluated indicators should be performed in every 
patient that is hospitalised for COPD exacerbations. In other words, the criterion to meet for every process indicator is $100 \%$ performance, regardless of patient characteristics. Consequently, results on the process indicators do reflect performance levels of the teams, and so should not be considered to be coincidental results arising from chance variation in small samples.

For outcome indicators, statistical power is essential for detecting true differences between the control and experimental groups. Thus, with low statistical power, only less confident conclusions can be drawn. In addition, risk adjustment is needed to identify and adjust for variation in patient outcomes that stem from differences in patient characteristics (or risk factors) across both groups [9-15]. Furthermore, the main outcome for the EQCP study was assessed at three time points: 6-month readmission, 30-day readmission, and 6month mortality. However, according to power calculation at least 400 patients are needed to detect an effect size of up to $11 \%$ for 6 -month readmission.

Since the outcome indicators are very prone to bias related to limited statistical power of the Belgian trial, this chapter will mainly focus on the results on the process indicators.

\section{Methods}

\section{Design}

To evaluate pathway effectiveness, a cluster randomised controlled trial (CRCT) was conducted, in which the experimental group included patients treated according to a specific care pathway, while the control group included patients receiving usual care. The methodology of the study was described in detail in Chapter 6 [1].

In the next three sections, some specific remarks are included on outcome measures, data input, and interim statistical analyses. In Appendix 1, statistical model details are provided.

\section{Outcome measurements}

In the overall EQCP study, the primary outcome measure is 6 -month readmission. The secondary outcome measures are 30-day readmission, 30-day and 6-month mortality, quality of life, and finally, performance on 24 process indicators regarding diagnostic, pharmacological, and non-pharmacological management. A complete overview of the outcome measures is provided in Table 3 of Chapter 5 . As explained above, this results chapter will mainly focus on the findings on the 24 process indictors (Chapter 5, Table 2). 


\section{Data input}

Data of 20 patients were collected centrally in every hospital and subsequently provided to Leuven University, where the data were input into a central database. A Microsoft Access ${ }^{\circledR}$ database was developed by a non-profit organisation specialising in healthcare information systems (http://www.higis.eu.org/). The database was designed in English to facilitate input of the data sheets from the different languages of the four countries in the EQCP study. Data input was extensively tested for errors and feasibility by the responsible researcher CL and KV.

Four students, enrolled in the Masters in Management and Policy programme, entered data into four central computers. Data input was supervised by the main researcher $(\mathrm{CL})$. The students were blinded with regard to the data and thus did not have information on the study aim and design. Three steps were taken to facilitate proper data input. Firstly, a user manual was produced that included (i) contact details of the responsible researcher (CL), (ii) detailed instructions on how to use the application; and (iii) specific remarks with regard to the patient data itself (i.e. medications, risks of errors, etc.). Secondly, the four students were trained for two days to master the data-input procedure. Thirdly, to minimise the risk of input errors, students were asked to report specific remarks (i.e. missing bundles on a specific time point) and uncertainties in an excel logbook. Finally, quality controls on data input were performed twice weekly by the responsible researchers ( $C L$ and $K V)$ in terms of verification of randomly picked samples of five patients. No major errors were found.

\section{Interim statistical analysis}

Differences in patient characteristics were analysed by using $\mathrm{Chi}^{2}$ and t-tests for categorical and continuous variables, respectively. Statistical significance was defined as a two-sided $p$ value of $<0.05$. Differences in results on process and outcome indicators between groups were evaluated at an individual level using random effects logistic regression (binary variables) or linear regression (continuous variables), accounting for the clustering effect (Appendix 1) [16]. Results on outcome indicators were adjusted for patient characteristics, including age, gender, comorbidities, previous hospital admissions, COPD severity, and selected clinical parameters (Table 1). All analyses were intention-to-treat and were carried out using SAS statistical software, version 9.2 for Windows.

\section{EQCP Belgium: preliminary results}

\section{Hospital inclusion}

For Belgium, 39 hospitals were invited to participate in the study in September 2008. Fifteen were interested, and after assessment of eligibility, 13 hospitals were included. Based on 
stratified randomisation [17;18], seven hospitals were assigned to the experimental group and six hospitals to the control group. After the randomisation process, one hospital in the control group withdrew because of changing leadership (Figure 1).

Figure 1. Flow diagram of hospital inclusion and randomisation

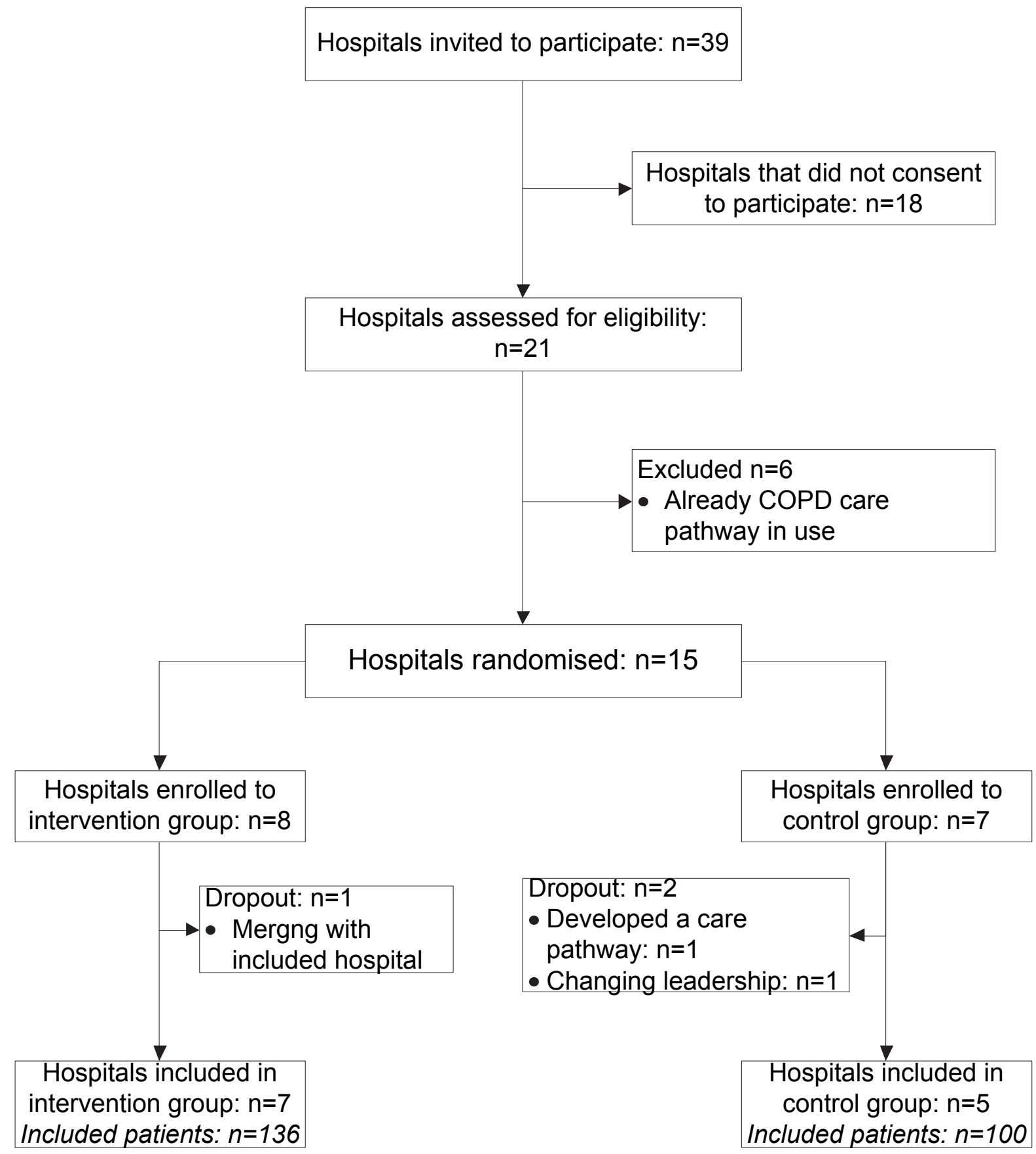

\section{Study timing}

The clinical audit before implementation was carried out between April and July 2009. Feedback on the results of the clinical audit was provided in March 2010. Consequently, organisations developed a care pathway between May and December 2010. Between March 
and November 2011 measurements on process and outcome indicators were performed in both the seven experimental hospitals and the five control hospitals. Data input and analysis occurred between September 2011 and January 2012.

Table 1. Baseline characteristics of the sample

\begin{tabular}{|c|c|c|c|}
\hline Variable & $\begin{array}{c}\text { Care pathway (CP) } \\
n=136\end{array}$ & $\begin{array}{l}\text { Usual care (UC) } \\
\quad n=100\end{array}$ & P Value* \\
\hline Male gender, n (\%) & $90(66.2)$ & $63(63.0)$ & 0.679 \\
\hline Mean age, years (SD) & $68.4(10.8)$ & $68.8(9.5)$ & 0.765 \\
\hline Cardiac failure, $n(\%) \dagger$ & $43(31.6)$ & $36(36.0)$ & 0.486 \\
\hline Diabetes, n (\%)‡ & $17(12.5)$ & $13(13.0)$ & 1.000 \\
\hline Smoker at admission, $\mathrm{n}(\%)$ & (51) 37.5 & $30(30.0)$ & 0.300 \\
\hline \multicolumn{4}{|l|}{$\begin{array}{l}\text { Number of hospitalisations in the } \\
\text { previous year, } \mathrm{n}(\%) \S\end{array}$} \\
\hline None & $84(61.8)$ & $50(50.0)$ & 0.315 \\
\hline 1 & $23(16.9)$ & $19(19.0)$ & \\
\hline 2 & $11(8.1)$ & $11(11.0)$ & \\
\hline 3 or more & $14(10.3)$ & $16(16.0)$ & \\
\hline BMI (SD) & $24.7(6.0)$ & $24.7(5.2)$ & 0.927 \\
\hline FEV1\% & $45.4(16.1)$ & $46.8(20.6)$ & 0.528 \\
\hline Missing data, $n(\%)$ & $24(17.6)$ & $22(22.0)$ & \\
\hline \multicolumn{4}{|l|}{ COPD severity, $n(\%) \S$} \\
\hline GOLD I: Mild & $4(2.9)$ & $7(7.0)$ & 0.031 \\
\hline GOLD 2: Moderate & $47(34.6)$ & $21(21.0)$ & \\
\hline GOLD 3: Severe & $57(41.9)$ & $38(38.0)$ & \\
\hline GOLD 4: Very Severe & $27(19.9)$ & $31(31.0)$ & \\
\hline $\mathrm{PaO}_{2}(\mathrm{kPa})$ & $9.34(3.43)$ & $9.34(3.00)$ & 0.998 \\
\hline Missing data, $n(\%)$ & $23(16.9)$ & $21(21.0)$ & \\
\hline $\begin{array}{l}\text { Treated by a pulmonologist, } n \\
(\%)\end{array}$ & $131(96.3)$ & $97(97.0)$ & 1.000 \\
\hline $\begin{array}{l}\text { Hospitalised in a } \\
\text { ward, } \mathrm{n}(\%)\end{array}$ & $113(83.3)$ & $82(82.2)$ & 0.728 \\
\hline
\end{tabular}

BMI, basal metabolic index ; FEV1, forced expiratory volume ; GOLD, Global Initiative for Obstructive Lung Disease (stages 1-4).

${ }^{*} \mathrm{Chi}^{2}$ and t-tests for categorical and continuous variables, respectively.

†Includes heart failure, arrhythmia, valvular disease, acute myocardial infarction, Ischemic heart disease [19].

łIncludes diabetes, uncomplicated and complicated [19].

§Missing data: (i) Previous readmissions: CP: $n=4$, UC: $n=3$; COPD severity: CP: $n=1$; UC: $n=3$.

\section{Hospital characteristics}

The total number of beds of included hospitals varied from 314 to 749 beds in the experimental group, and from 169 to 714 beds in the control group. Annual volume of hospitalised COPD patients varied from 126 to 405 patients in the experimental group, and from 133 to 377 in the control group. Four of 7 experimental hospitals were teaching hospitals, while only one control hospital had a teaching status. Dedicated pneumology 
wards were present in only two control hospitals. A formal rehabilitation programme was available in all seven experimental hospitals, but in only 1 of 5 control hospitals.

\section{Patient characteristics}

The final sample consisted of 236 patients, with 136 patients receiving care pathway care, and 100 patients receiving usual care (Table 1). At admission, there were no significant differences with regard to age, gender, selected clinical conditions, or number of previous admissions. However, in the control group, the number of patients with very severe COPD was $11 \%$ higher (UC: $31.0 \%$ vs. CP: $19 \%$ ), and the number of patients with moderate COPD was $13 \%$ lower (UC: $21.0 \%$ vs. CP: $34.6 \%)(p=0.031)$.

\section{Results on process indicators}

Results on process indicators are presented in Table 2, according to each core process: diagnostic management (Table 2, nos. 1-5); pharmacological management (Table 2, nos. 69); and non-pharmacological management (Table 2, nos. 10-24). Appendix 2 provides a guided on the results tables (table 2, 3 and 4). Seven of 24 indicators (29.2\%) (Table 2, nos. $3,10,13,14,17,19,24)$ and 25 of 42 subcomponents (59.5\%) (Table 2, nos. 3a, 7a, 8c-d, 12a-c, 13a-d, 14a-e, 17a, 18a-c, 19a-b, 24a, 24i-j, 24I) showed better results of $10 \%$ and up to $50 \%$ in the care pathway group (Table 2). However significant improvements were found for only three indicators, specifically: education on inhaler therapy (CP: $40.7 \%$ vs. UC: $1.0 \%$; OR=2120.27; $95 \% \mathrm{Cl}, 3.17-1417636.22$ ); education on oxygen therapy (CP: $40.0 \%$ vs. UC: $0.0 \%$; OR=11.77; $95 \% \mathrm{Cl}, 1.59-87.25$ ); measurement of basal metabolic index (BMI) (CP: $75.5 \%$ vs. UC: $27.0 \%$; OR=78.61; $95 \% \mathrm{Cl}, 2.26-2736.73$ ); and for 10 subcomponents. The 10 subcomponents were adequate dose prescription of corticoids (CP: $92.1 \%$ vs. UC: 74.4\%; OR=2.80; 95\% Cl, 1.24-6.33); education on inhaler medication (CP: $68.1 \%$ vs. UC: 3.1\%; OR=64.12; $95 \% \mathrm{Cl}, 19.22-213.88$ ); education on inhaler technique (CP: $67.4 \%$ vs. UC: 3.1\%; OR=62.69; 95\% Cl, 18.18-208.93); education on inhaler device (CP: $67.4 \%$ vs. UC: $4.1 \%$; OR=46.01; $95 \% \mathrm{Cl}, 15.89-133.20$ ); providing leaflet on inhaler therapy (CP: $55.7 \%$ vs. UC: $39.2 \%$; OR=4.60; $95 \% \mathrm{Cl}, 1.69-12.50$ ); education on oxygen source (CP: $56.7 \%$ vs. UC: $0.0 \%$; OR=13.60; $95 \% \mathrm{Cl}, 1.85-99.53$ ); education on oxygen equipment (CP: $53.3 \%$ vs. UC: $0.0 \%$; OR $=21.41 ; 95 \% \mathrm{Cl}, 6.99-66.63$ ); education on oxygen precautions (CP: $60.0 \%$ vs. UC: $0.0 \%$; OR=14.27; $95 \% \mathrm{Cl}, 1.95-104.50)$; providing patient letter with information on follow-up appointment (CP: $59.1 \%$ vs. UC: $43.4 \%$; OR=4.18; 95\% Cl, 1.64-10.64); and planning of follow-up appointment (CP: $89.0 \%$ vs. UC: $67.0 \%$; OR=4.43; 95\% Cl, 1.05-18.65) (Table 2). In addition, two indicators in the control group-arterial blood gas (ABG) measurement at discharge and assessment of social support within two days-had lower performance at $20 \%$ 
(UC: $48.6 \%$ vs. CP: $27.1 \%$; OR=0.34; $95 \% \mathrm{Cl}, 0.09-1.29$ ) and $10 \%$, respectively (UC: $92.5 \%$ vs. $\mathrm{CP}: 82.6 \% \mathrm{OR}=0.27 ; 95 \% \mathrm{Cl}, 0.00-17.89)$. This difference, however, was not significant.

Overall, optimal performance-defined as correct performance of an indicator in more than $90 \%$ of patients-was found in both groups for three indicators: performance of chest X-ray, prescription of short-acting bronchodilators, and prescription of long-acting dilatators (Table 2, nos. 2, 6, 7). Optimal performance was also observed for five subcomponents: performance of X-ray during hospitalisation, performance of X-ray within 24 hours, systemic glucorticosteroids prescribed during hospitalisation, assessment of residential status within 3 days of admission, and availability of letter for general practitioner in medical record (Table 2, nos. 2a-b, 8a, 24b, 24k). Additionally, in the care pathway group optimal performance was found for two indicators: assessment of smoking status and administration of controlled oxygen therapy (Table 2, nos. 10, 11). Optimal performance was also found for two subcomponents: performance of electrocardiogram during hospitalisation and assessment of residence during hospitalisation (Table 2, nos. 3a, 24a). In the control group, optimal performance for two subcomponents was found: assessment of living status within 3 days and assessment of social support within 3 days (Table 2, nos. 24d, 24f).

Aside from these results, performance showed a downward trend. Very suboptimal performance, defined as correct performance of an indicator in less than $50 \%$ of patients, was found in both groups for 12 of 24 indicators (50.0\%), including adequate prescription of corticoids, smoking cessation intervention education for inhaler and oxygen therapy, performance of rehabilitation tests and referral to rehabilitation, management of nutritional overweight and underweight, pneumococcal vaccination, adequate discharge management, ABG measurement before discharge (Table 2, nos. 8, 12-16, 18, 19, 21-24); and for 8 of 42 subcomponents $(19.0 \%)$ for nutritional management, adequate prescription of corticoids, smoking cessation, and prescription of home oxygen therapy (Table 2, nos. 8b, 12b, 12e, 18a-c, 23a-). Additionally in the control group, very suboptimal management was found for 16 additional subcomponents. Except for oral administration of corticoids, these subcomponents dealt with non-pharmacological management (Table 2, nos. 8d, 12a, 12c, $12 d, 13 a-d, 14 a-e, 19 a-b, 24 g, 24 i)$. However, it is notable that 5 of 24 indicators $(20.8 \%)$ (Table 2, nos. 12, 13, 14, 23, 24), and 12 of 42 subcomponents (28.6\%) (Table 2, nos. 12a-c, $12 \mathrm{e}, 13 \mathrm{~d}, 14 \mathrm{~d}-\mathrm{e}, 23 \mathrm{~b}, 24 \mathrm{~g}-\mathrm{i}, 24 \mathrm{l})$ had missing data of up to $60 \%$; both groups had about the same amount of missing data. All of these missing data were related to patient questionnaires. The biggest reason for this high rate of missing data was that 40 patient questionnaires were lost due to internal organisation mail errors. 


\section{Results on outcome indicators}

Risk adjustment was used to account for the impact of individual risk factors as reported in Table 1. No significant differences were found between care pathway and control groups (Table 3 and 4), although potentially interesting non-significant improvements in the care pathway group were found for 30 -day readmission (CP: $13.6 \%$ vs. UC: $22.2 \%$ ) (Table 3 ) and length of stay (LOS) (CP: 11.65 days vs. UC: 13.36 days) (Table 4). 


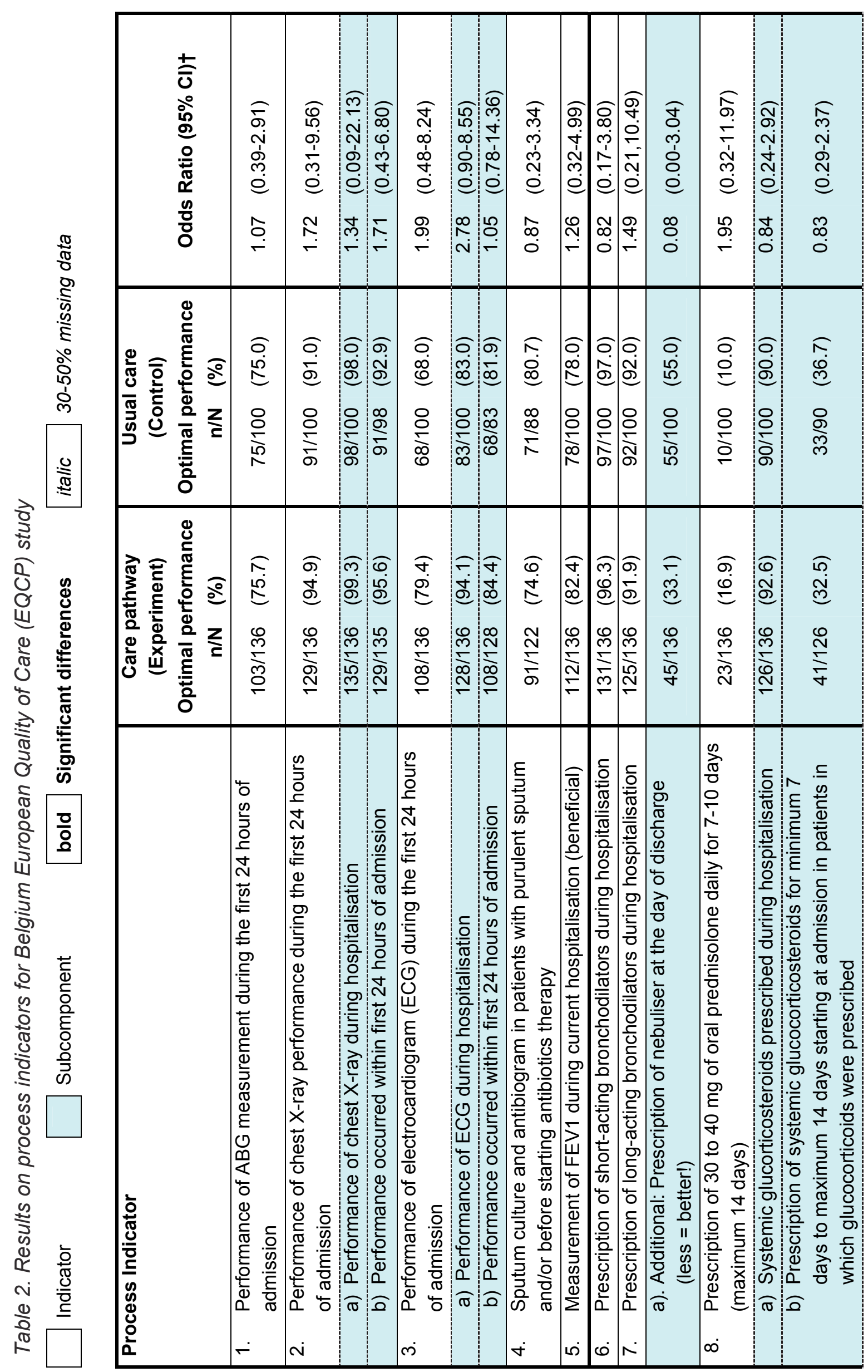




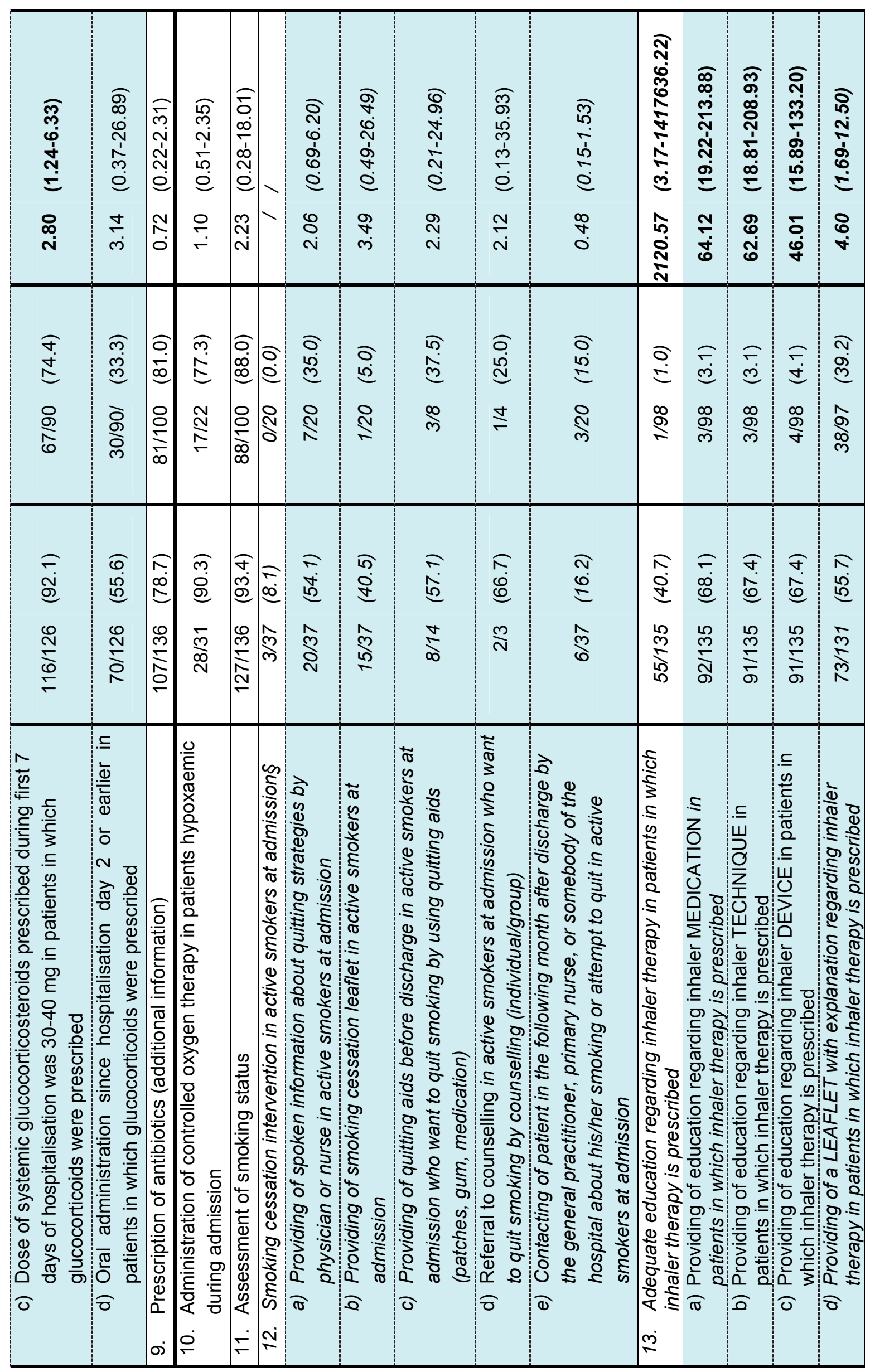




\begin{tabular}{|c|c|c|c|c|c|c|c|c|c|c|c|c|c|c|c|c|c|}
\hline 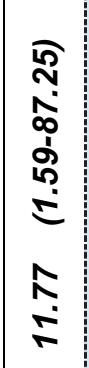 & 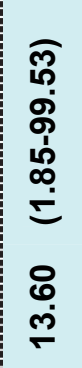 & 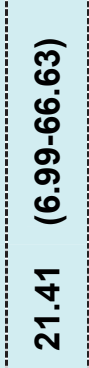 & 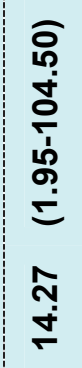 & 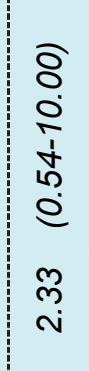 & 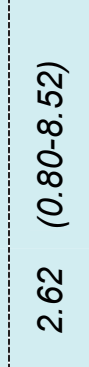 & $\begin{array}{l}\widehat{\widehat{0}} \\
0 \\
0 \\
0 \\
0 \\
0 \\
0 \\
\hat{0} \\
\hat{1} \\
0\end{array}$ & 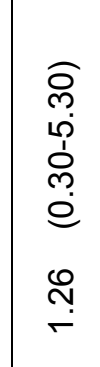 & 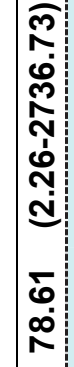 & 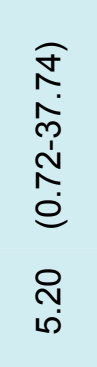 & 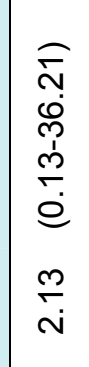 & 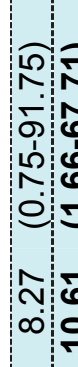 & 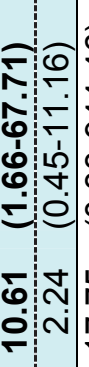 & 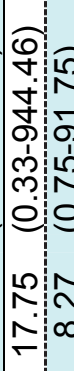 & 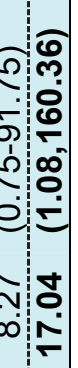 & 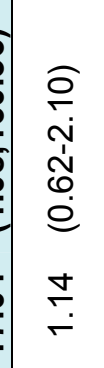 & $\begin{array}{l}\widehat{\sigma} \\
\dot{+} \\
\dot{1} \\
\dot{+} \\
\dot{0} \\
\infty \\
\infty \\
\stackrel{0}{0}\end{array}$ & 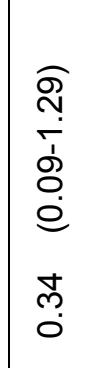 \\
\hline 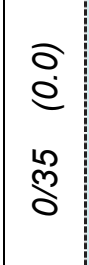 & $\begin{array}{l}0 \\
0 \\
0 \\
\stackrel{m}{0} \\
\stackrel{0}{0}\end{array}$ & $\begin{array}{l}0 \\
0 \\
0 \\
\stackrel{0}{0} \\
\stackrel{0}{0}\end{array}$ & 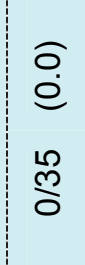 & 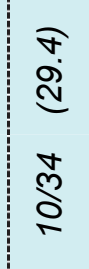 & 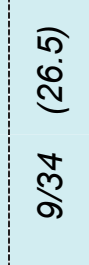 & 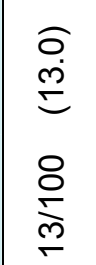 & 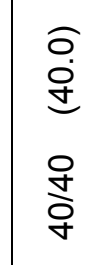 & 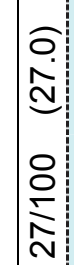 & 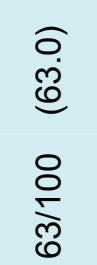 & $\begin{array}{l}\widehat{\infty} \\
\stackrel{\dot{J}}{\Xi} \\
\stackrel{N}{\mathcal{J}}\end{array}$ & $\begin{array}{l}\infty \\
+ \\
5\end{array}$ & 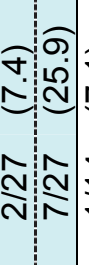 & $\stackrel{\nabla}{\stackrel{\nabla}{二}}$ & $\begin{array}{l}\stackrel{v}{*} \\
\end{array}$ & 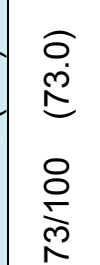 & 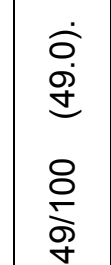 & 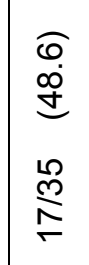 \\
\hline 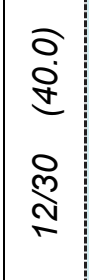 & $\begin{array}{l}\widehat{T} \\
0 \\
0 \\
0 \\
\stackrel{0}{N} \\
\stackrel{\Gamma}{=}\end{array}$ & $\begin{array}{l}\text { m } \\
\text { Dं } \\
\stackrel{0}{0} \\
0 \\
0 \\
0\end{array}$ & $\begin{array}{l}0 \\
0 \\
0 \\
0 \\
\frac{m}{\infty} \\
\infty\end{array}$ & $\begin{array}{l}\widehat{0} \\
\stackrel{0}{0} \\
\hat{0} \\
\hat{N} \\
\stackrel{N}{2}\end{array}$ & 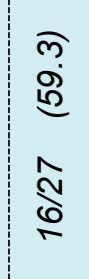 & 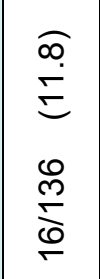 & 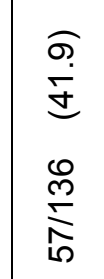 & 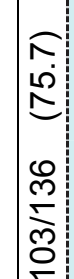 & 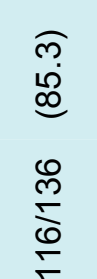 & 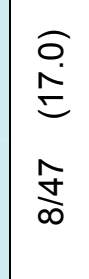 & 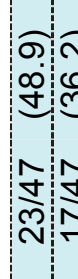 & \begin{tabular}{c:c}
\cline { 1 - 1 } & \multirow{\gamma}{*}{} \\
\hdashline & 0
\end{tabular} & Ni: & 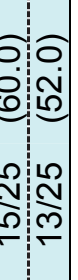 & 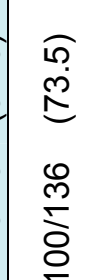 & 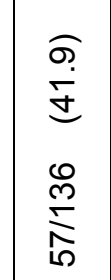 & 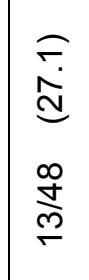 \\
\hline 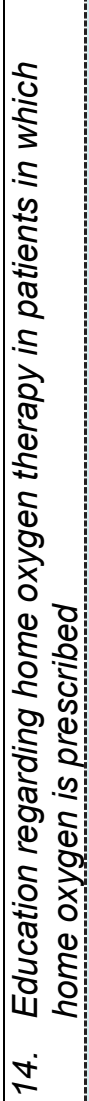 & 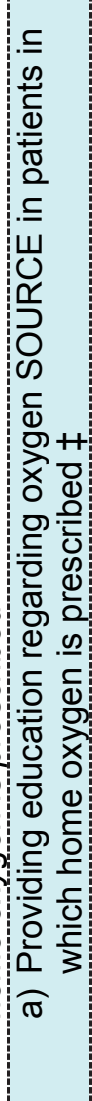 & 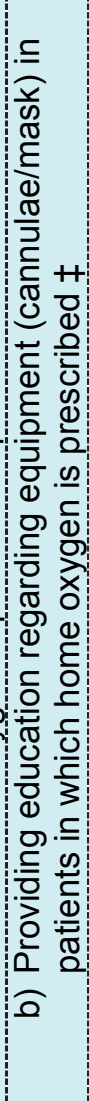 & 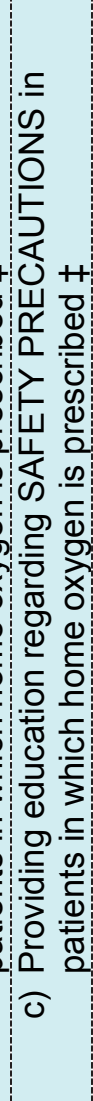 & 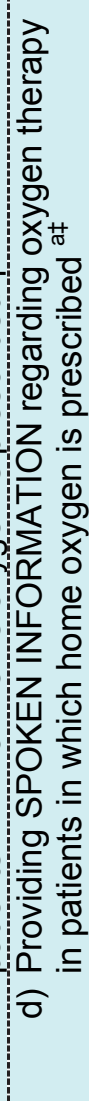 & 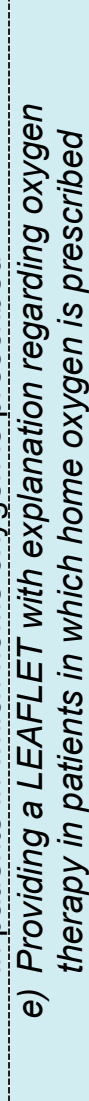 & 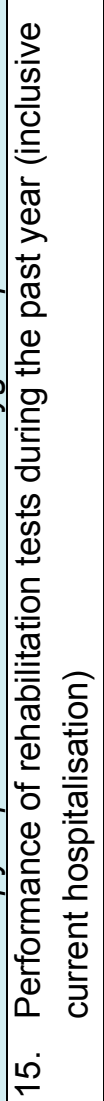 & 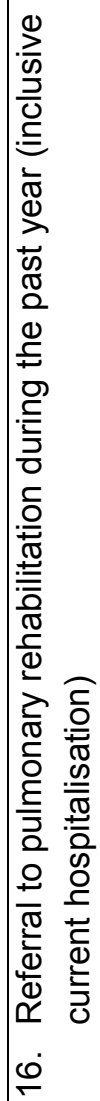 & 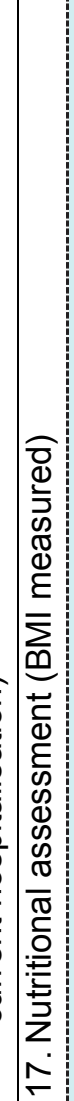 & 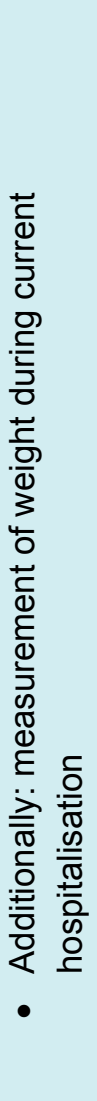 & 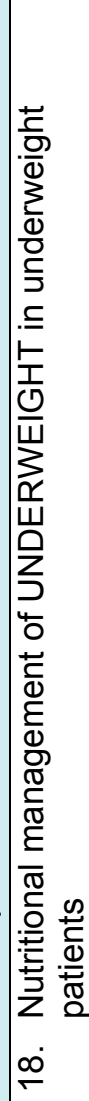 & 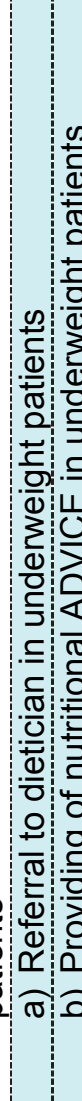 & 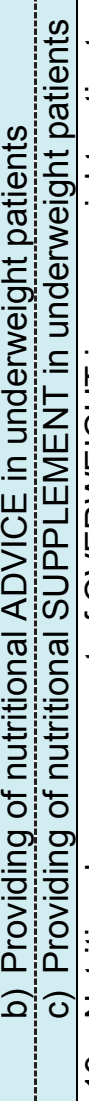 & 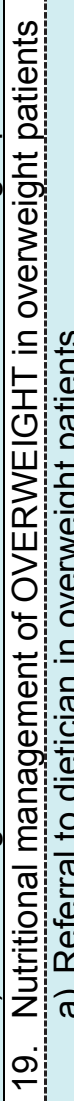 & 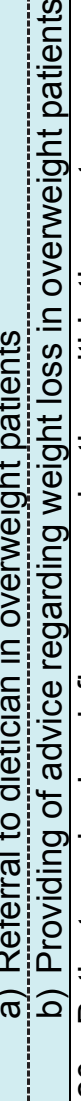 & 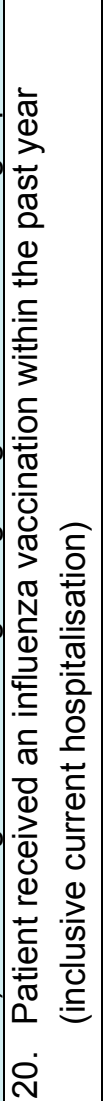 & 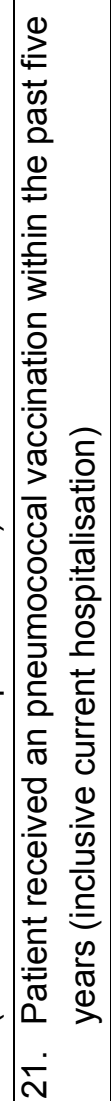 & 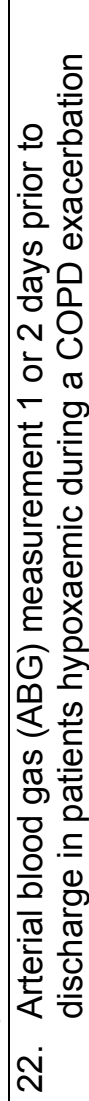 \\
\hline
\end{tabular}




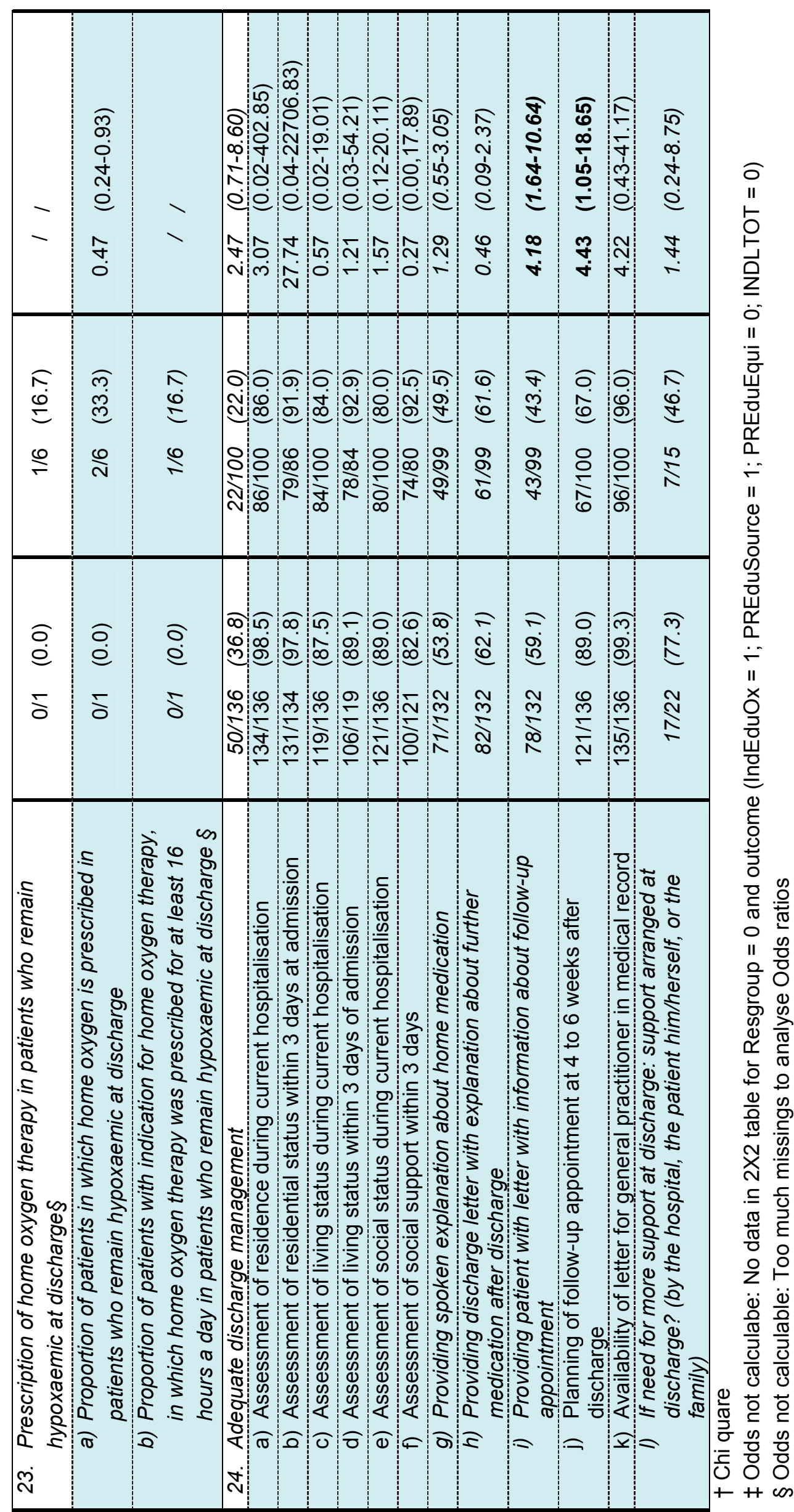




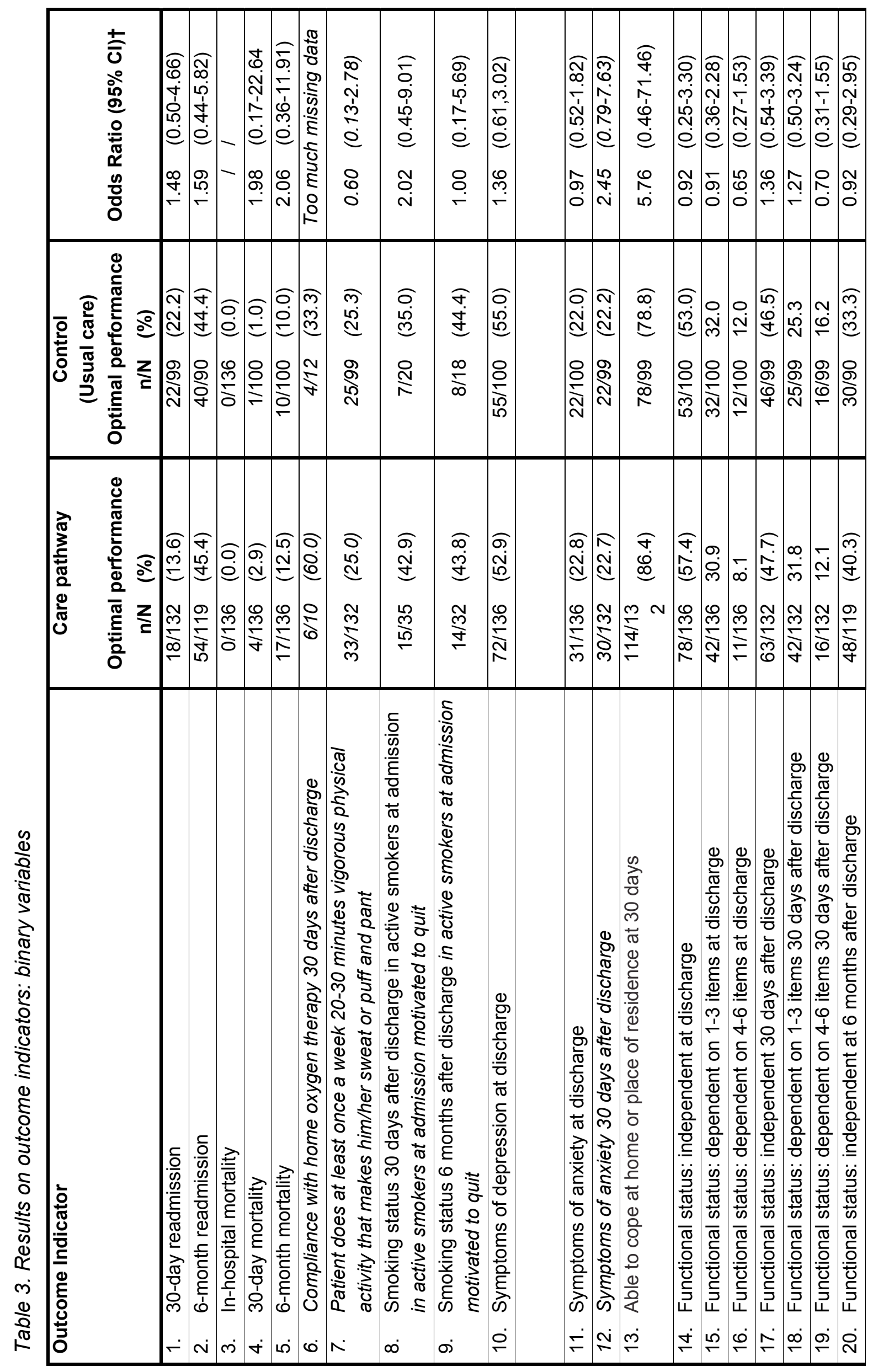




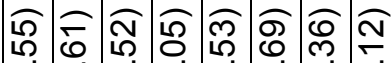
ง

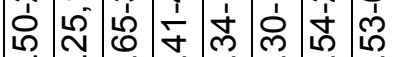
e e e e e e

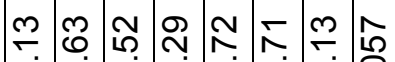
$\because 0 \div 000$

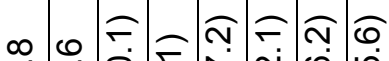

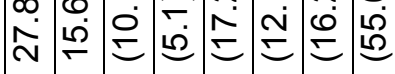
৪ ৪ ৪ ৪ ৪ ঞ

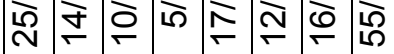

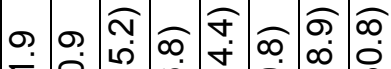

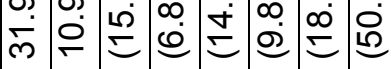

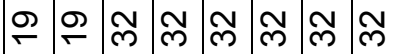
雍

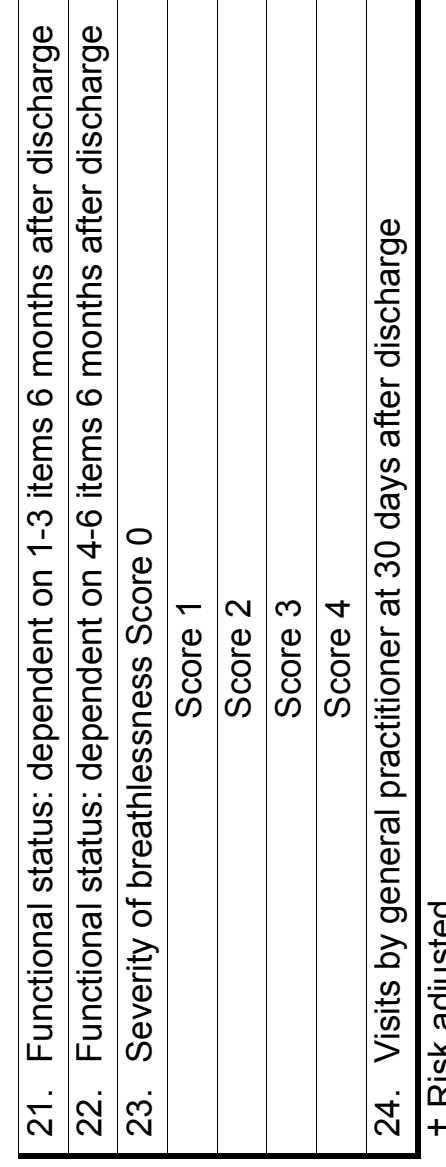

\begin{tabular}{|c|c|c|c|c|c|c|c|c|c|c|c|c|}
\hline 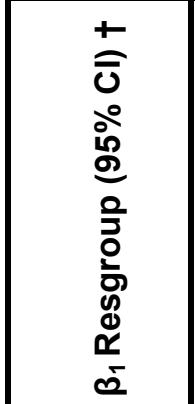 & 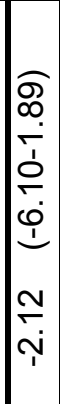 & 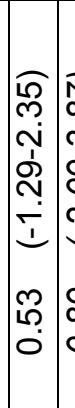 & 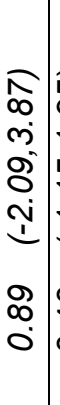 & 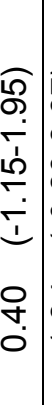 & 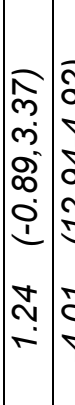 & 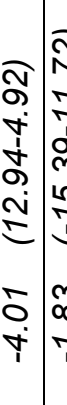 & 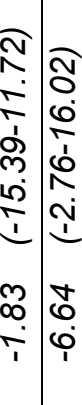 & 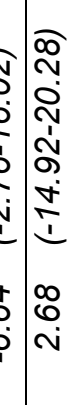 & 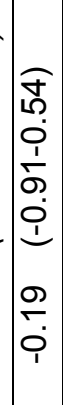 & $\begin{array}{l}\widehat{T} \\
\infty \\
0 \\
0 \\
\infty \\
\infty \\
0 \\
0 \\
1 \\
\\
8 \\
8 \\
0 \\
1\end{array}$ & 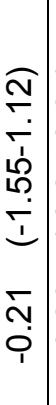 & 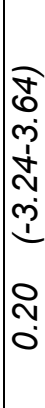 \\
\hline 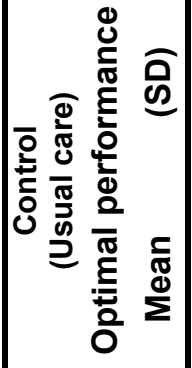 & 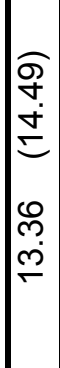 & 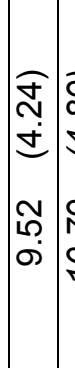 & 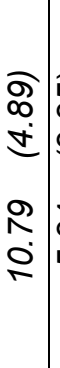 & $\begin{array}{l}\widehat{\omega} \\
\tilde{m} \\
\tilde{m} \\
\dot{m} \\
\tilde{m} \\
\dot{\omega}\end{array}$ & 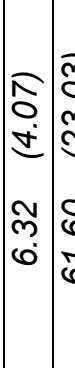 & 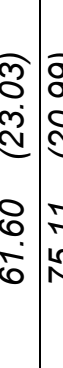 & 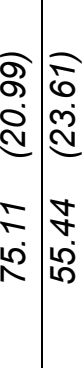 & 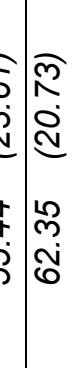 & 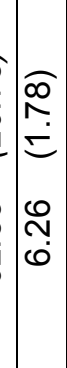 & 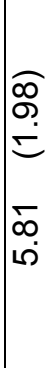 & 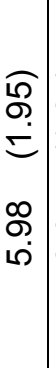 & 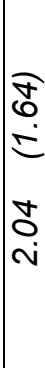 \\
\hline 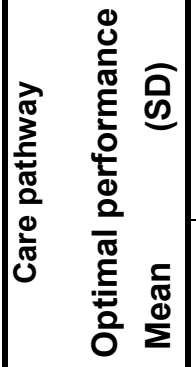 & 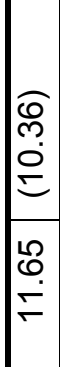 & 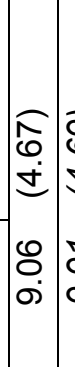 & $\begin{array}{l}\sigma \\
\sigma \\
\dot{\theta} \\
\vdots \\
\sigma \\
\sigma\end{array}$ & 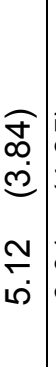 & 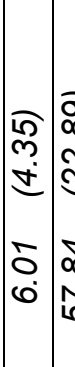 & 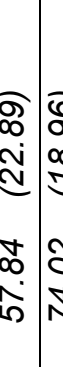 & 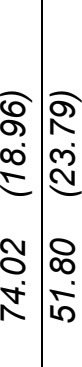 & 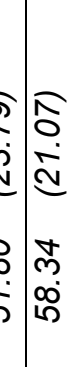 & 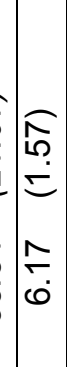 & $\begin{array}{l}\widehat{0} \\
\stackrel{0}{=} \\
= \\
0 \\
0\end{array}$ & 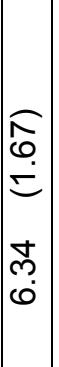 & 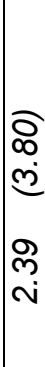 \\
\hline
\end{tabular}
$\hat{\imath}$ 


\section{Discussion}

Findings of the Belgium component of the EQCP study show that in the experimental group (i.e. care pathway was implemented), 7 of 24 process indicators $(29.2 \%)$ and 25 of 42 process subcomponents (59.5\%) improved from $10 \%$ up to $50 \%$ (Table 2). In addition, better results were found for outcome indicators regarding 30-day readmission and LOS (Table 23). Statistical significance was rarely found, but this was expected because of the low statistical power resulting from analysing only the Belgian part of the larger EQCP study. According to sample size calculations, at least 400 patients in each arm were required to attain a statistical power of $80 \%(\alpha=0.05)$. The Belgian sample size included 100 and 136 patients in the experimental and control group, respectively, implying that statistical power was very low. Therefore, the chance of detecting a statistically significant difference was small. However, as discussed earlier, our criterion was all process indicators had to meet $100 \%$ performance, regardless of patient characteristics. Consequently, for the process indicators, improvement of up to $50 \%$ in the care pathway group reflect better performance levels, and so should not be considered to be coincidental results arising from chance variation in small samples.

Despite large improvements in the care pathway group, there still exists room for much improvement, as 11 of 24 indicators $(45.8 \%)$ and 8 of 42 subcomponents (20\%) had a performance of less than $50 \%$. We need to bear in mind that in the case of multicomponent indicators, low performance of just one or two subcomponents will result in suboptimal performance of the main indicator (Table 2, i.e. nos. 15, 18, 32). For several indicators, organisations performed quite well for most subcomponents. Thus, to improve the main indicator, they need to focus on improving only one or two subcomponents.

The normalisation theory of May et al. [20] states that the normalisation process consists of the collective action-the work-involved in enacting a complex intervention. When that work leads to the routine embedding of an intervention in everyday practice, it may be said to have become normalised. Normalisation is only one possible outcome of collective action. Others include adoption, where a complex intervention is adopted but does not become routinely embedded in everyday work, and rejection, where users disregard, subvert, or otherwise refuse to a use a complex intervention [20]. In our study, a considerable amount of indicators are still suboptimal performed, which indicates that by implementing the care pathway, the set of key interventions was adopted but not yet routinely embedded in daily practice. Therefore, we believe that continuous quality improvement will be needed to obtain optimal performance on the different indicators, and furthermore to enhance sustainability of the improved results.

Results on outcome indicators show a non-significant improvement in 30-day readmission and LOS. Compared to the literature, we found that the 30 -day readmission rate 
in the care pathway group $(13.6 \%)$ was more or less within the range of rates reported in the literature (range: $8.9-16 \%$ ) [9;11;21]. Moreover, rather low rates were found in both groups for in-hospital mortality (both groups: 0.0\%), 30-day mortality (CP: 2.9\%; UC: 1.0 ), and 6month mortality (CP: 12.5\%; UC 10.0\%) (Table 4), in comparison with earlier studies, which found much higher rates for In-hospital mortality (4.7-8.3\%) [13;22-27], 30-day mortality (4.5$8.4 \%)[24 ; 25]$, and 6-month mortality (18-24\%) [21;26]. However, the present results need to be interpreted with caution due to limited statistical power.

\section{Methodological strengths and limitations}

Firstly, an important strength of our research is its cluster randomised design. When evaluating a complex intervention that affects different levels of the organisation, this kind of design provides the most valid results. In contrast, with a quasi-experimental design (see review on care pathways and COPD, Chapter 3 [28]), there is a strong possibility that better results arise not because of care pathway implementation, but because of other reasons like history effect, Hawthorn effect, selection bias, or contamination of the control group.

Secondly, close examination of the randomisation strategy using stratification [1], reveals that hospitals were comparable with regard to size and annual volume of hospitalised patients. Also type of hospital (teaching vs. non-teaching) was balanced in the initial sample. However, because of dropout of two hospitals in the control group, 4 of 7 hospitals $(57.1 \%)$ in the experimental group, as opposed to 1 of 5 hospitals (20\%) in the control group that had a teaching status, which might have influenced the results. On the other hand, all participating hospitals in the Belgian EQCP study were members of the Belgian Dutch Clinical Pathway Network (BDCPN; www.nkp.be) [29], implying that the study coordinators of both experimental and control groups were already experienced in the development, implementation, and evaluation of care pathways.

Thirdly, we want to highlight the three components included in the complex intervention. The first component included feedback on actual performance. Participants of the experimental hospitals clearly stated that the feedback on the actual care process (before care pathway implementation) showed them exactly where the bottlenecks were in their actual care process. This helped them to focus on those key interventions that really needed improvement. The results on process indicators seem to confirm these statements. Indeed, the most important improvements were found for process indicators that were suboptimally performed in the clinical audit before implementation, including prescription of corticoids, education, smoking cessation, and referral to rehabilitation (Table 2). Overall, understanding their bottlenecks - through the comparison of results on actual care processes and evidencebased key interventions-appears to motivate teams to improve their actual care process and is therefore believed to be a strong determinant for adoption of new knowledge [30-33]. 
The second component included the integration of the set of 38 evidence-based key interventions. As described in Chapter 5, the set of key interventions produced by the eightstep method, was well accepted by the seven experimental teams. This was because of validity and clinical applicability of the interventions, indicating that the eight-step strategy (Chapter 5) was an important approach to increase adoption of these key interventions by the different teams. However, to know to what extent the key interventions were effectively implemented and which actions were undertaken to improve performance on process indicators, implementation analyses needed be performed (Chapter 8).

Finally, the third component-including (i) a structured protocol for development and implementation of the care pathway, and (ii) strategies for effective knowledge sharingturned out to be very useful for distilling knowledge out of the feedback and bringing evidence into practice. This especially occurred during the meetings with the team and team change experts, where experiences, successes and bottlenecks (i.e. difficulties regarding implementation of educational strategies) were discussed.

Fourthly, another strength of this study concerns the validity of quality measures: The process and outcome indicators were developed based on the literature, Delphi survey, and face-to-face consensus meetings, and were piloted during the clinical audit before pathway implementation [34].

Fifthly, we highlight the importance of using a logbook listing excluded patients. These patients were admitted with COPD exacerbations but were not included in the study due to a specific reason. Seven of 12 participating Belgian hospitals provided a logbook containing blinded data on excluded patients. Two other hospitals (one experimental and one control), coordinated by one study coordinator, estimated that each hospital had around five excluded patients. However, the coordinator stated that the logbooks of both hospitals were lost by mail.

Of the 7 hospitals that provided a logbook, 6 hospitals reported a range of 6 to 12 excluded patients, while one hospital reported three excluded patients. For the seven hospitals, a total of 67 patients admitted with COPD exacerbations were not included in the study; 34 of the patients were admitted in the experimental hospitals, and 33 in the control hospitals. The mean age of the excluded patients was comparable to that of patients included in the study, for both experimental (care pathway or CP) and control (usual care or UC) groups (CP: 70.4, SD 2.0; UC: 73.3 years, SD 2.1). With regard to gender, in the experimental group 17 of 34 excluded patients were male $(50 \%)$, while in the control group only 9 of 33 excluded patients were male (27.3\%). Although this difference was not significant (Fisher exact, $p=0.08$ ), we need to interpret these findings with caution because of the small sample size. The most frequently reported reason for exclusion was 'not interested in participating' (CP: $n=17 / 34,50 \%$; UC: $n=18 / 33$; $54.5 \%$ ). Most of the remaining patients 
were excluded because of the preset exclusion criteria: (i) having mental disorders and thus unable to provide informed consent and/or to understand and read the native language (CP: 9/34, 25.5\%; 7/33, 21.1\%); admitted to another ward (CP: $1 / 34,2.9 \%$; UC: $4 / 33,12.1 \%$ ); in bad condition (CP: $2 / 34,5.9 \%$; UC: $2 / 33,6.1 \%$ ); and already included in another study (CP: $n=2 / 34,5.9 \%$; UC: $n=0 / 34,0.0 \%$ ). Of the 3 remaining patients, 1 'needed a pacemaker' (CP), 1 was discharged without notifying the researchers $(\mathrm{CP})$, and 1 was admitted for less than 3 days (UC). Overall, these findings indicate that one in every two or three admitted patients were not included in the study, leading to possible selection bias. Although excluded patients were comparable to included patients in age, they differed with regard to gender distribution ( $50 \%$ males vs. $27.3 \%$, respectively). For future studies, we recommend that more detailed information should be collected on the patient characteristics of excluded patients, specifically with regard to their comorbidities and COPD severity.

Finally, one of the challenges of cRCTs is that data collection occurs at different sites. Hence, it is difficult and time-consuming to follow up the data collection across the different organisations. In our study, only 20 patients per hospital needed to be followed up, and the data collection duties were distributed among three parties: teams, patients, and external researcher. We realise that many indicators were followed up, though, with regard to all process indicators and 8 of 15 outcome indicators, all indicators were binary, implying that they were measured by using one variable. In case of the 10 multicomponent process indicators, we measured two to maximum five variables to compose the indicators. Overall, data collection was very complete with regard to these binary indicators, especially when performed by the team members and the external researcher. This indicated that the workload burden for data collection for these parties was feasible. We think that the low number of patients that needed to be included per organisation, as well as providing the data collection forms classified per collection time point and delivered in two binders for each organisation, played an important role in making data collection successful. With regard to data collected via self-reported patient questionnaires, we observed a high rate of missing data for questionnaires that needed to be returned by mail 30 days after discharge. Indeed, up to $40 \%$ of missing data were noted for 5 of 24 indicators $(20.8 \%)$ and 12 of 42 of their underlying subcomponents (28.6\%), and for 3 of 15 outcome indicators (20\%). In total 84 of 236 patients did not return their questionnaire (35.6\%). However, 40 of these 84 patient questionnaires (47.6\%) from two hospitals were lost due to mailbox problems associated with the study coordinator responsible for these two hospitals.

In conclusion, although logistic and economic issues can make conducting cRCTs challenging, we believe that opportunities to collect data through multicentre studies should be fully utilised. However, self-reported patient questionnaires, especially during the follow-up period, should be limited. Consequently, collecting data on patient opinions and experiences 
during the follow-up period should be integrated into other opportunities like follow-up consultations.

\section{Conclusion}

The results of the Belgium component of the larger EQCP study suggest that implementation of a care pathway has potential to improve care processes and clinical outcomes. However, due to the necessarily small sample size, and hence limited statistical power, strong conclusions on effectiveness can only be confidently drawn when the final results of the other three involved countries become available in 2013.

Continuous quality improvement will be needed to obtain optimal performance on the different indicators, and to enhance sustainability of the improved results.

\section{Acknowledgements}

We acknowledge the support of the Clinical Research Fund of UZ Leuven, Belgium. We also acknowledge Pfizer Belgium, Pfizer Italy, Pfizer Ireland, and Pfizer Portugal, who supported this research by providing an unrestricted educational grant. The autonomy of E-P-A and all involved academic institutions with regard to scientific independence and intellectual property on methodology is guaranteed. We also acknowledge Timothy Mutsvari for performing the multilevel analyses. 


\section{References}

1 Vanhaecht K, Sermeus W, Peers J, Lodewijckx C, Deneckere S, Leigheb F, Decramer M, Panella M. The impact of care pathways for exacerbation of Chronic Obstructive Pulmonary Disease: rationale and design of a cluster randomized controlled trial. Trials 2010;11:111.

2 Campbell MK, Mollison J, Grimshaw JM. Cluster trials in implementation research: estimation of intracluster correlation coefficients and sample size. Stat Med 2001;20:391399.

3 Fitzner K, Heckinger E. Sample size calculation and power analysis: a quick review. Diabetes Educ 2010;36:701-707.

4 Ukoumunne OC, Gulliford MC, Chinn S, Sterne JA, Burney PG. Methods for evaluating area-wide and organisation-based interventions in health and health care: a systematic review. Health Technol Assess 1999;3:iii-92.

5 Global Initiative for Chronic Obstructive Lung Disease (GOLD). Global strategy for the diagnosis, management, and prevention of chronic obstructive pulmonary disease, updated 2010. [http://www.goldcopd.org/guidelines-global-strategy-for-diagnosismanagement.html]

6 National Institute for Health and Clinical Excellence (NICE). Chronic obstructive pulmonary disease - Management of chronic obstructive pulmonary disease in adults in primary and secondary care; 2010. [http://guidance.nice.org.uk/CG101]

7 Pierson DJ. Clinical practice guidelines for chronic obstructive pulmonary disease: a review and comparison of current resources. Respir Care 2006;51:277-288.

8 Siafkas N, Wedzicha J. Management of acute exacerbation of chronic obstructive pulmonary disease In Siafkas N, (ed): Management of chronic obstructive pulmonary disease. European Respiratory Monograph. Sheffield, European Respiratory Society Ltd, 2006, vol 11, pp 387-400.

9 Almagro P, Barreiro B, Ochoa de EA, Quintana S, Rodriguez CM, Heredia JL, Garau J. Risk factors for hospital readmission in patients with chronic obstructive pulmonary disease. Respiration 2006;73:311-317.

10 Garcia-Aymerich J, Farrero E, Felez MA, Izquierdo J, Marrades RM, Anto JM. Risk factors of readmission to hospital for a COPD exacerbation: a prospective study. Thorax 2003;58:100-105.

11 Gonzalez C, Servera E, Ferris G, Blasco ML, Marin J. Risk factors of readmission in acute exacerbation of moderate-to-severe chronic obstructive pulmonary disease. Arch Bronconeumol 2004;40:502-507. 
12 Gonzalez C, Servera E, Marin J. Importance of noninvasively measured respiratory muscle overload among the causes of hospital readmission of COPD patients. Chest 2008;133:941-947.

13 Price LC, Lowe D, Hosker HS, Anstey K, Pearson MG, Roberts CM. UK National COPD Audit 2003: Impact of hospital resources and organisation of care on patient outcome following admission for acute COPD exacerbation. Thorax 2006;61:837-842.

14 Roberts CM, Lowe D, Bucknall CE, Ryland I, Kelly Y, Pearson MG. Clinical audit indicators of outcome following admission to hospital with acute exacerbation of chronic obstructive pulmonary disease. Thorax 2002;57:137-141.

15 Shaughnessy P, Hittle D. Overview of risk adjustment and outcome measures for home health care agencey OBQI reports; 2012.

16 Diez-Roux AV. Multilevel analysis in public health research. Annu Rev Public Health 2000;21:171-192.

17 Hosker H, Anstey K, Lowe D, Pearson M, Roberts CM. Variability in the organisation and management of hospital care for COPD exacerbations in the UK. Respir Med 2007;101:754-761.

18 Roberts CM, Barnes S, Lowe D, Pearson MG. Evidence for a link between mortality in acute COPD and hospital type and resources. Thorax 2003;58:947-949.

19 Elixhauser A, Steiner C, Harris DR, Coffey RM. Comorbidity measures for use with administrative data. Med Care 1998;36:8-27.

20 May C, Finch T, Mair F, Ballini L, Dowrick C, Eccles M, Gask L, MacFarlane A, Murray E, Rapley T, Rogers A, Treweek S, Wallace P, Anderson G, Burns J, Heaven B. Understanding the implementation of complex interventions in health care: the normalization process model. BMC Health Serv Res 2007;7:148.

21 Groenewegen KH, Schols AM, Wouters EF. Mortality and mortality-related factors after hospitalization for acute exacerbation of COPD. Chest 2003;124:459-467.

22 Aburto M, Esteban C, Moraza FJ, Aguirre U, Egurrola M, Capelastegui A. COPD exacerbation: mortality prognosis factors in a respiratory care unit. Arch Bronconeumol 2011;47:79-84.

23 Bustamante-Fermosel A, De Miguel-Yanes JM, Duffort-Falco M, Munoz J. Mortalityrelated factors after hospitalization for acute exacerbation of chronic obstructive pulmonary disease: the burden of clinical features. Am J Emerg Med 2007;25:515-522.

24 Chang CL, Sullivan GD, Karalus NC, Mills GD, McLachlan JD, Hancox RJ. Predicting early mortality in acute exacerbation of chronic obstructive pulmonary disease using the CURB65 score. Respirology 2011;16:146-151.

25 Eriksen N, Vestbo J. Management and survival of patients admitted with an exacerbation of COPD: comparison of two Danish patient cohorts. Clin Respir J 2010;4:208-214. 
26 Gunen H, Hacievliyagil SS, Kosar F, Mutlu LC, Gulbas G, Pehlivan E, Sahin I, Kizkin O. Factors affecting survival of hospitalised patients with COPD. Eur Respir J 2005;26:234241.

27 Roche N, Zureik M, Soussan D, Neukirch F, Perrotin D. Predictors of outcomes in COPD exacerbation cases presenting to the emergency department. Eur Respir J 2008;32:953961.

28 Lodewijckx C, Sermeus W, Vanhaecht k, Panella M, Deneckere S, Leigheb F, Decramer M: Impact of care pathways for in-hospital management of COPD exacerbations: a systematic review. Int J Nurs Stud. 2011; 48:1445-56.

29 Van Gerven E, Vanhaecht K, Deneckere S, Vleugels A, Sermeus W. Management challenges in care pathways: conclusions of a qualitative study within 57 health-care organization. Intl J Care Pathw 2010;142-149.

30 Harkleroad A, Schirf D, Volpe J, Holm MB. Critical pathway development: an integrative literature review. Am J Occup Ther 2000;54:148-154.

31 Institute of Medicine. Taking the first steps; in Institute of Medicine, (ed): Crossing the quality Chiasm. Washington, DC 20418, National Academy Press, 2001, pp 39-60.

32 Pearson SD, Goulart-Fisher D, Lee TH. Critical pathways as a strategy for improving care: problems and potential. Ann Intern Med 1995;123:941-948.

33 Vanhaecht K, Deneckere S, Van Gerven E, Lodewijckx C, Janssens I, Van Zelm R, Boto $P$, Panella M, Biringer E, Sermeus W. The 7-phase method to design, implement and evaluate care pathways. Intl J Pers Cent Med 2011. In press.

34 Lodewijckx C, Sermeus W, Panella M, Deneckere S, Leigheb F, Troosters T, Boto P, Mendeze R, Decramer M, Vanhaecht K. Quality indicators for in-hospital management of exacerbation of chronic obstructive pulmonary disease: results of an international Delphi study. J Adv Nurs. 2012. Accepted for publication 21 April 2012. 


\section{Appendix 1: Statistical model details}

It is reasonable to assume that observations or data from the same group or cluster would be correlated. Hence, naïve approaches for analysing data cannot be used since they assume that data are independent (i.e. no clustering). Ignoring the clustering of data may lead to incorrect conclusions, since variability would be over- or underestimated, resulting in biased p-values. When data are independent, regression models can be used. However, in the presence of correlations, regression models are extended to multilevel models.

Figure 2. Two-level model

Level 1: Hospital
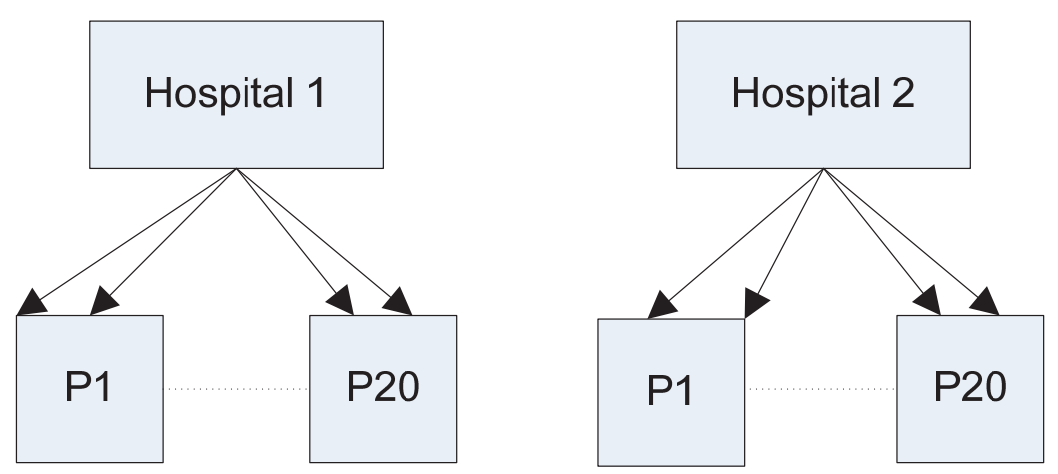

\section{Statistical multilevel model:}

$Y_{i j}=\beta_{0}+\beta_{1} x_{i j}+b_{i}+\varepsilon_{i j}$

- $\quad$ where $\mathrm{Y}_{\mathrm{ij}}$ is the dependent variable or outcome from patient $j$ belonging to hospital $i$,

- $\quad$ and $\mathrm{x}_{\mathrm{ij}}$ is the covariate from patient $\mathrm{j}$ belonging to hospital $\mathrm{i}$

In this model, $x_{i j}$ includes the covariate 'Resgroup' $(1=$ Experimental group; $2=$ control group),

- $\beta_{0}$ is the intercept

- $\quad \beta_{1}$ is the regression coefficients explaining the effect of the covariate $x_{i j}$ "Resgroup" (Experimental / control)

- $\quad b_{i}$ is the random effects at hospital level (clustering effect)

With $b_{i} \sim N\left(0, \sigma^{2}\right) \quad\left(\mathrm{N}\right.$ : b has a normal distribution; $\sigma^{2}=$ tau $=$ variance at cluster level (very high = very high clustering effect)

$$
\begin{aligned}
& \text { Continuous outcomes: } \\
& \text { UN }(1,1)=\sigma_{1}^{2}=\text { variance on hospital level (clustering effect) } \\
& \text { Residual }=\sigma_{2}^{2}=\text { variance at patient level } \\
& \text { ICC }=\frac{U[1,1]}{U[1,1]-\text { Residual }}
\end{aligned}
$$


- $\varepsilon_{\mathrm{ij}}$ is the residuals/errors at the patient level (deviation for the overall mean only for continuous variables).

With $\varepsilon_{i j}=N\left(0, \sigma^{2}\right)==>\sigma^{2}=$ variance at the patient level

\section{Statistical models for specific outcomes:}

1) Binary outcomes: multilevel

Logit $\frac{P R(Y=1)}{1-P R(Y=1)}=\beta_{0}+\beta_{1}$ Resgroup $+\beta_{i}$

With $b_{i} \sim N\left(0, \sigma^{2}\right)$

2) Continuous outcomes: multilevel

$Y_{i j}=\beta_{0}+\beta_{1}$ Resgroup $+b_{i}+\varepsilon_{i j}$

With $b_{i} \sim N\left(0, \sigma_{1}^{2}\right)$

And $\varepsilon_{i j} \sim N\left(0, \sigma_{2}^{2}\right)$ 


\section{Appendix 2: Guided by the results}

\section{Presentation of the indicators}

There will be single component and multicomponent indicators.

- Single component indicators are composed of one component. A particular case is scored as ' 1 ' if the single component is well performed, and thus satisfies the conditions of the indicator.

- Multicomponent indicators are composed of two or more components. A particular case is scored as ' 1 ' if all underlying components are scored as ' 1 ' (and thus are well performed).

Indicators are indicated by a number and displayed without shading.

Components are indicated by a letter and displayed with blue shading.

\section{Presentation of results}

- Odds ratios and $95 \%$ confidence interval $(\mathrm{Cl})$

\section{Odds ratio:}

- The odds ratio is one of a range of statistics used to assess the risk/chance of a particular outcome (or disease) if a certain factor (or exposure) is present. The odds ratio is a relative measure of risk that reveals the likelihood that a subject who is exposed to the factor under study will develop the outcome as compared to another subject who is not exposed.

- If the odds are greater than one then the event is more likely to happen than not. If the odds are less than one, then the outcome is less likely to occur. http://www.blackwellpublishing.com/specialarticles/jcn_10_268.pdf

Example: The odds ratio for performance of chest $\mathrm{X}$-ray in care pathway group/usual care is 1.72 . Thus, patients in the care pathway group are 1.72 times more likely for to receive a chest X-ray.

95\% Cl:

- When the $95 \% \mathrm{Cl}$ for the differences in two proportions includes the value 1 , the accompanying significance test does not provide a significant result.

- When the $95 \% \mathrm{Cl}$ for the differences in two proportions does not include the value 1 , the accompanying significance test provides a significant result. 
- $\quad \beta_{1}$ Resgroup and $95 \% \mathrm{Cl}$

\section{$\beta 1$ Resgroup:}

- $\quad \beta 1: \beta$ is the regression coefficient that explains the slope of the difference between the scores of the intervention and the control group

- If the coefficient is greater than 0 , the difference is positive (outcome in intervention group > control group); if coefficient is less than zero, difference is negative (outcome in experimental group < outcome in control group).

Example: Odds for LOS is -1.76 , so LOS in intervention group will be lower than in control group (under condition being significant!)

\section{5\% Cl:}

- When the $95 \% \mathrm{Cl}$ for the differences in two proportions includes the value 0 , the accompanying significance test does not provide a significant result.

- When the $95 \% \mathrm{Cl}$ for the differences in two proportions does not include the value 0 , the accompanying significance test provides a significant result.

\section{Specific meaning of scores on HADS Scale and SGRQ}

- HADS: Hospital Anxiety and Depression Scale:

- Depression/anxiety was measured with the Hospital Anxiety and Depression Scale (score: 0-21).

- Score of $\geq 8$ means caseness (possible or probable presence of depression/anxiety)

- Caseness can be specified in two categories:

- score of 8-10 means possible case (possible presence for depression/anxiety)

- score of $\geq 11$ means probable case (probable presence for depression/anxiety)

- SGRQ: St. George Respiratory Questionnaire

- Quality of life was measured with the St. George Respiratory Questionnaire. The scoring includes four separate scores:

- Total score (0-100)

- 3 subscores: symptoms, activity, and impact (0-100)

- NOTE: the lower the score, the better the HRQL 
Chapter 8:

Process analyses in seven Belgian hospitals: level of implementation of a set of evidence-based key interventions for inhospital management of COPD exacerbation 


\section{Context}

Chapter 6 presented the rationale and design of the European Quality of Care Pathways (EQCP) study on the impact of care pathways for COPD exacerbations. Chapter 7 presented the preliminary results of the Belgian EQCP study. The present chapter presents results of a process evaluation of the Belgian EQCP study.

Process evaluations within trials explore the implementation, receipt, and setting of an intervention. These evaluations assist researchers in several ways. Firstly, they promote understanding on how outcomes are achieved and what factors promote or hinder them [14]. Secondly, they help determine why a programme was or was not successful, and they are essential in order to distinguish between interventions that are inherently faulty (failure of intervention concept or theory) and those that are just poorly delivered (implementation failure) $[1 ; 2 ; 5 ; 6]$. Finally, process evaluations are particularly useful in multisite trials, where the 'same' intervention may be implemented and received in different ways [2].

Elements of process evaluations include assessment of fidelity (quality), dose delivered (completeness), dose received (exposure and satisfaction), reach (participation rate), recruitment, and context [7].

In the Belgian EQCP study, all seven participating experimental hospitals implemented a care pathway that included three active components: (i) feedback on actual performance, (ii) integration of a set of evidence-based key interventions for in-hospital management of COPD exacerbations (Chapter 5), and (iii) training on development and implementation of the care pathway [8]. The process evaluation described in this chapter addresses the implementation of the second component of the care pathway: integration of a set of 38 evidence-based key interventions. This implementation analyses focusses on four implementation aspects (fidelity, dose delivered, recruitment, and context) and has three main aims: (i) to explore the level of complete inclusion of the different key interventions, (ii) to study the actions undertaken to improve performance of the implemented key interventions, and (iii) to explore barriers for implementation of the key interventions.

\section{Methodology}

\section{Questionnaire for implementation analyses}

To explore the level of implementation, undertaken improvement actions, and barriers for implementation, we developed a self-reporting questionnaire.

The questionnaire included all care activities that were followed up in the EQCP study by the 24 process indicators (Chapter 5, Table 3). Essentially, these 24 process indicators refer to care activities that (i) have high impact on patient outcomes according to the literature and 
expert opinion [9-12], and (ii) are suboptimally performed according to both earlier studies [13] and results of the seven Belgian hospitals (Chapter 7, Table 2). In other words, we are particularly interested in the results of the implementation analysis on these care activities, because strong implementation of these key interventions has high potential for improving the performance of care processes and for optimising results on clinical outcomes [9-12]. In addition, including these care activities allowed us to correlate results on the implementation analyses with the results on the performance indicators.

It was explicitly decided to not study all 38 key interventions and underlying components (which refer to a total of 77 care activities; Chapter 5, Table 1). Indeed, this would have been excessively time-consuming for the respondents and consequently might compromise the accuracy and completeness of reporting overall.

In total, based on the 24 process indicators and subcomponents, 48 activities were included for implementation analysis in the questionnaire. This questionnaire included three main parts based on the three core processes for in-hospital management of COPD exacerbations: diagnostic tests, pharmacological management, and non-pharmacological management. For each of the 48 care activities, respondents were asked to fill out whether the particular key intervention was entirely included in their developed care pathway (Yes/No). Consequently, if the answer was 'yes', the respondent was asked to indicate whether specific actions were undertaken to improve the performance of this key intervention (Yes/No). If the answer was again 'yes', the respondent was asked to describe the undertaken answers. If the answer on the initial question regarding complete inclusion of the key intervention was 'no', respondents were asked to report their reason for failing to include or only partially including the key intervention. Possible answer categories for the latter question were (i) 'not organisable' (respondents were asked to report why it was not organisable); (ii) 'no consensus within the team'; and (iii) 'other' (respondents were asked to describe what was meant by 'other'). Multiple answers were possible.

The questionnaire was piloted by a care pathway coordinator of one of the seven included Belgian experimental hospitals. We asked him to appraise the questionnaire for clarity, feasibility, completeness, and time needed to complete it. Additionally, we requested this feedback within one week. Some minor suggestions were made on formulation of a few key interventions, but overall, the questionnaire was approved for all these criteria.

\section{Survey and participants}

The process evaluation was conducted in the seven experimental hospitals included in the Belgian EQCP study. The implementation analysis was conducted by e-mail. The questionnaire was sent to the study coordinators on Monday, 12 January 2012, by the first author (CL). Invitation for participation in the implementation analysis, together with 
explanation about the aim of the evaluation and the procedure was included. The study coordinators were asked to complete the questionnaire together with one or more team members, and to return the completed questionnaires by e-mail no later than Friday, 27 January 2012. In addition, respondents were requested to include in their reply developed care pathway documents, like time tasks and checklists, to give the research team an idea about the composition and structure of the care pathway. Confidentiality was guaranteed in this way that the results of the respondents remained strictly confidential to the researchers [14]. A reminder e-mail was sent to coordinators on Monday, 30 January 2012. For missing values or unclear answers, the study coordinators were queried by mail or phone.

\section{Data analyses}

We analysed the reported levels of implementation of care activities using the following summary statistics: (i) number of hospitals where the care activity was completely implemented in the care pathway, and (ii) number of hospitals where a specific action was undertaken. In addition, reported actions undertaken to improve performance of the included care activities and reported reasons for failing to include or partial inclusion were listed and categorised into general concepts based on content and format. Data were analysed using the statistical software program SPSS version 19 (International Business Machines Corporation, Armonk, New York, 2011).

\section{Results}

\section{Response rate}

Study coordinators of all seven hospitals returned the completed questionnaire within the provided time span. An additional e-mail with the request to complete missing values resulted in $100 \%$ completion.

\section{Hospital characteristics}

Four of the 7 hospitals were teaching hospitals (57.1\%) (Table 1). Hospital size ranged between 300 and 400 beds in four hospitals (57.1\%), while in the other three hospitals size varied from 589 to 749 beds. None of the hospitals had dedicated respiratory wards; however, in each hospital, 26 to 34 beds were dedicated to hospitalised COPD patients. Finally, all included hospitals had a rehabilitation programme for COPD patients. 
Table 1. Hospitals characteristics

\begin{tabular}{|c|c|c|c|c|}
\hline Hospital & Teaching status & $\begin{array}{c}\text { Total number of } \\
\text { beds }\end{array}$ & $\begin{array}{c}\text { Annual patient } \\
\text { volume (2007) }\end{array}$ & $\begin{array}{c}\text { Number of beds } \\
\text { dedicated for } \\
\text { COPD patients }\end{array}$ \\
\hline H1 & Teaching & 314 & 126 & 30 \\
\hline H2 & Non-teaching & 334 & 169 & 32 \\
\hline H3 & Non-teaching & 369 & 155 & 33 \\
\hline H4 & Non-teaching & 382 & 233 & 34 \\
\hline H5 & Teaching & 589 & 170 & 26 \\
\hline H6 & Teaching & 598 & 405 & 33 \\
\hline H7 & Teaching & 749 & 208 & 32 \\
\hline
\end{tabular}

\section{Overall implementation level and undertaken actions}

According to respondents, 24 of 48 evaluated care activities $(50.0 \%)$ were completely included in all seven hospitals (100\%), and 18 of 48 care activities (37.5\%) were fully implemented in 6 of 7 hospitals (85.7\%) (Table 2). Only 4 care activities (8.2\%) were reported as partially implemented, ranging from inclusion in 2 hospitals (28.6\%) to 4 hospitals (57.1\%). These four activities were "measurement of ABGs between 30 and 60 minutes after start of oxygen therapy", "follow-up contact with regard to smoking cessation, "performance of revalidation tests", and "arterial blood gas (ABG) measurement prior to discharge in hypoxemic patients".

Furthermore, the reported implementation level of the care activities according to the three core processes (diagnostic, pharmacological, and non-pharmacological management) indicated that diagnostic care activities were best implemented, and pharmacological interventions were least included (Table 2).

Table 2. Level of implementation of care activities based on the number of hospitals in which each care activity was reported as completely included in the care pathway.

\begin{tabular}{|c|c|c|c|c|c|}
\hline & \multicolumn{5}{|c|}{ Reported implementation level } \\
\hline & $\begin{array}{c}\text { Completely } \\
\text { implemented } \\
\text { in all } 7 \\
\text { hospitals } \\
(100.0 \%)^{*}\end{array}$ & $\begin{array}{c}\text { Completely } \\
\text { implemented } \\
\text { in } 6 \text { of } 7 \\
\text { hospitals } \\
(85.7 \%)\end{array}$ & $\begin{array}{l}\text { Completely } \\
\text { implemented } \\
\text { in } 5 \text { of } 7 \\
\text { hospitals } \\
(71.4 \%)\end{array}$ & $\begin{array}{c}\text { Completely } \\
\text { implemented } \\
\text { in } 4 \text { of } 7 \\
\text { hospital } \\
(57.1 \%)\end{array}$ & $\begin{array}{c}\text { Completely } \\
\text { implemented } \\
\text { in } 2 \text { of } 7 \\
\text { hospitals } \\
(28.6 \%)\end{array}$ \\
\hline $\begin{array}{l}\text { All care activities, } \\
\mathrm{n} / \mathrm{N}(\%)\end{array}$ & $24 / 48(50.0)$ & $18 / 48(37.5)$ & $2 / 48(4.2)$ & 1/48 (2.1) & $3 / 48(6.3)$ \\
\hline $\begin{array}{l}\text { Diagnostic care } \\
\text { activities, n/N (\%) }\end{array}$ & $4 / 5(80.0)$ & $1 / 5(20.0)$ & & & \\
\hline $\begin{array}{l}\text { Pharmacological } \\
\text { care activities, } \\
\mathrm{n} / \mathrm{N}(\%)\end{array}$ & $3 / 8(37.5)$ & $3 / 8(37.5)$ & 2/8 (25.0) & & \\
\hline $\begin{array}{l}\text { Non- } \\
\text { pharmacological } \\
\text { care activities, } \\
\mathrm{n} / \mathrm{N}(\%)\end{array}$ & $17 / 35(48.6)$ & $14 / 35(40.0)$ & & $1 / 35(2.9)$ & $3 / 35(8.6)$ \\
\hline
\end{tabular}

${ }^{*}$ Relative number of hospitals where the care activity is reported as implemented. 
Examining the reported implementation level per hospital, we found a range of $80 \%$ to $100 \%$ (Figure 1). Only one hospital $(\mathrm{H} 2)$ reported a lower implementation level of $66.7 \%$, with less pharmacological and non-pharmacological interventions being reported as completely included.

Figure 1. Reported percentage of completely included care activities at the hospital level

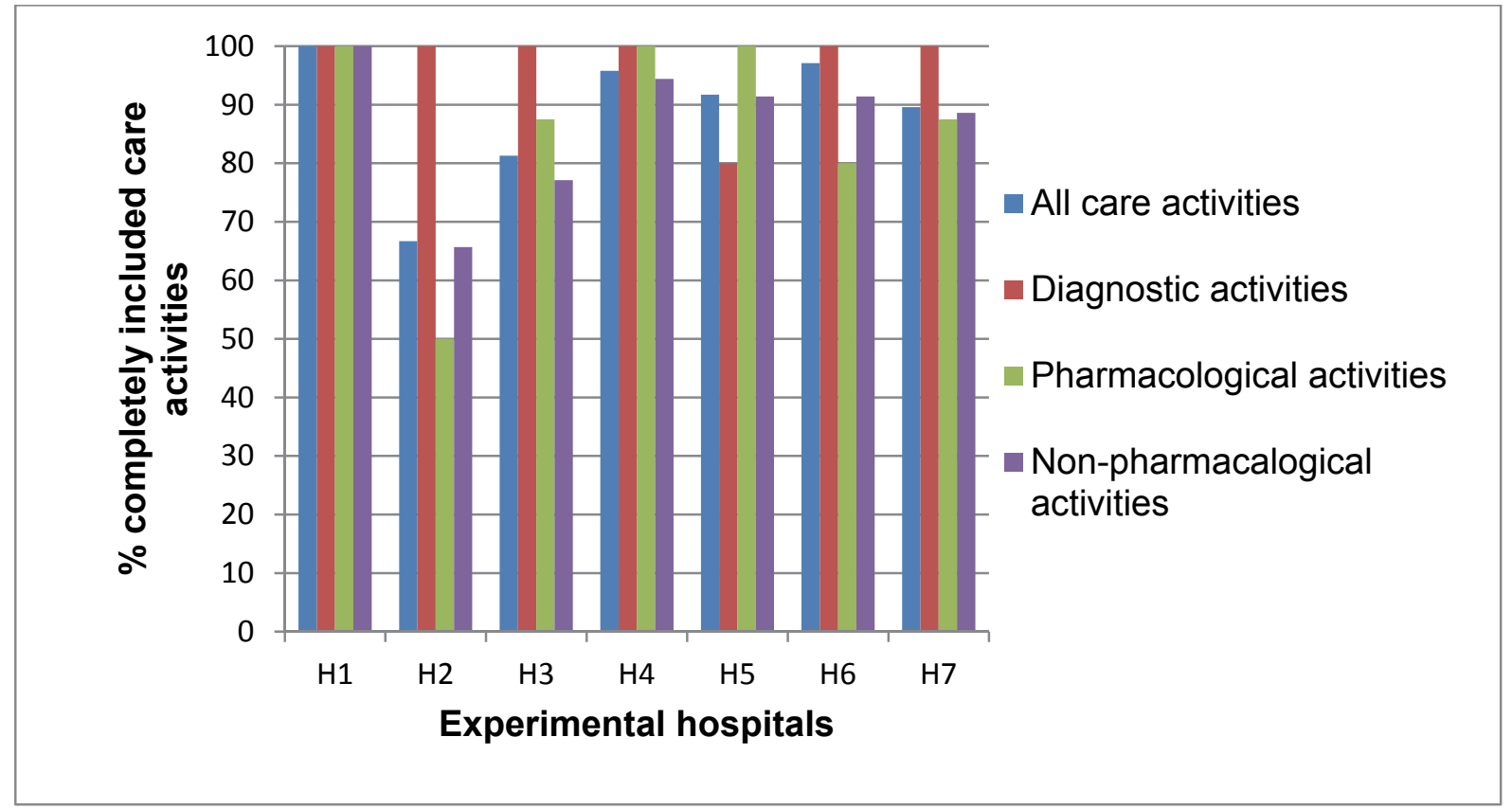

The percentage of completely included key interventions for which improvement actions were reported ranged from $28.6 \%$ to $97.7 \%$ over the seven hospitals (Figure 2). Looking at the overall included care activities, two hospitals ( $\mathrm{H} 2$ and $\mathrm{H} 6)$ reported considerably fewer improvement actions. Furthermore, $\mathrm{H} 2$ was the only hospital that reported no improvement actions for pharmacological care activities. Most frequently reported actions were (i) inclusion in checklist of the care pathway, standing order, standard performed action; recruitment or specific assignment of multidisciplinary staff (tabaccologist, occupational therapist, physiotherapist, dietician, and social worker); staff education, information technology (IT) applications (reminders, automatic generation of e-mails); and generation of materials and time slots for patient education.

Most frequently reported reasons for non-inclusion or partial inclusion of the key interventions were associated with organisational factors. Detailed descriptions of these organisational factors were rarely provided. These include 'tabaccologist not recruited yet' and 'devices for rehabilitation tests very recently purchased'. Other commonly reported reasons for non-implementation were 'no consensus within the team', 'depending on the prescription of the physician', and 'depending on the condition of the patient'. 
Figure 2. Percentage of included care activities for which an action was reported at the hospital level

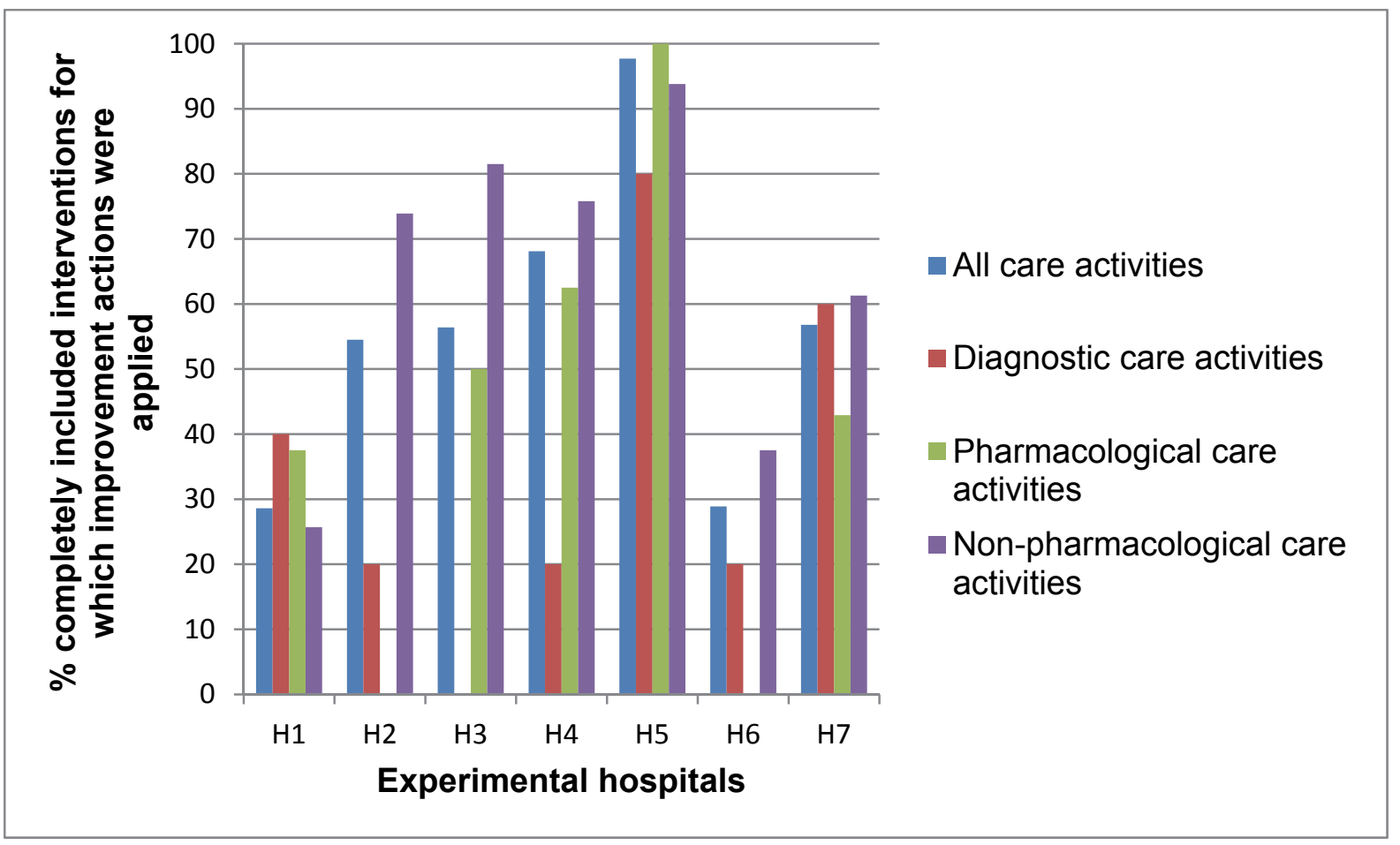

\section{Reported implementation level and undertaken actions according to diagnostic, pharmacological, and non-pharmacological management}

Table 3 shows for each evaluated care activity (i) the number of hospitals that reported complete inclusion of the care activity into the care pathway, (ii) the number of hospitals that reported an improvement action for the included care activity, (iii) the reported action, (iv) the reported reason for failing to include or for only partial inclusion of the care activity in the care pathway.

With regard to diagnostic management (Table 3, Part I), according to respondents, 4 of 5 care activities (80.0\%) were completely implemented in all hospitals, whereas the remaining activity, performance of sputum culture, was completely implemented in six hospitals (Table 2; Table 3, Part I). With regard to actions for improving the performance of diagnostic care activities, the greatest number of actions were reported for inclusion of arterial blood gas (ABG) measurement at admission, in example "inclusion into pathway checklist", "reminder in patient record", and "education of staff" (Table 3 Part I, no. 1).

For the second core process of pharmacological management (Table 3, Part II), 6 of 8 evaluated interventions $(75.0 \%)$ were reported as completely implemented in six to seven hospitals, (Table 2; Table 3, Part II). Reported as less optimally implemented were specific interventions regarding systemic corticoid therapy (dose, time span, and administration route) and prescription of long-acting bronchodilators and inhaled corticoids (Table 3, Part II, 
no. 5). The most frequently reported reasons for non-implementation were 'therapy depends on condition of the patient' and 'therapy depends on prescription of the patient' (Table 3, Part II). In addition, remarkable reasons for non-implementation were found for the subcomponent 'switch of intravenous to oral corticoid therapy' (Table 3, Part II, no. 5c):, 'no consensus within the team', and 'what would patient think of care if no intravenous therapy was started'. Finally, most improvement actions were taken for prescription of corticoids, including checklists, standard orders, and use of standard medication schemes (Table 3, Part II, no. $5 a-5 c)$.

Finally, with regard to non-pharmacological interventions, 17 of 34 evaluated activities $(48 \%)$ were fully implemented in all seven hospitals, and 14 of 35 activities (40\%) were completely included in six of seven hospitals (Table 2; Table 3, Part III). Only four nonpharmacological care activities $(11.4 \%)$ were reported as not or partially implemented in two to four hospitals (Table 2; Table 3, Part III), mostly because of organisational reasons and no consensus within the team: (i) ABG measurement after starting oxygen, (ii) follow-up contact regarding smoking cessation one month after discharge, (iii) performance of rehabilitation tests, and (iv) ABG measurement in hypoxaemic patients before discharge (Table 3, Part III, nos.1, 4e, 7, 15). Furthermore, the number of reported actions undertaken to improve performance of non-pharmacological interventions was considerably higher than those for diagnostic and pharmacological management. These included specific interventions like alignment of specialised caregivers like tabaccologist, dieticians, occupational therapists, and physiotherapists; development and use of education tools like leaflets and placebo inhalers; planning of education session for patients; and generation of automatic e-mails to a dietician and social worker when a COPD patient is admitted.

\section{Care pathway documents}

All seven hospitals provided their care pathway documents, which all included a Gantt Chart or time-task matrix listing the different interventions in one column according to the responsible team members and cross-aligning these entries with columns pertaining to time $[15 ; 16]$. In all hospitals the time task was integrated into the patient record and included a clear starting and end point. The most important differences in time tasks were alignment of the tasks to the different professional disciplines, integration of the key interventions at different points in the time process, and the overall time span of the care pathway, which varied from 4 to 10 days. 


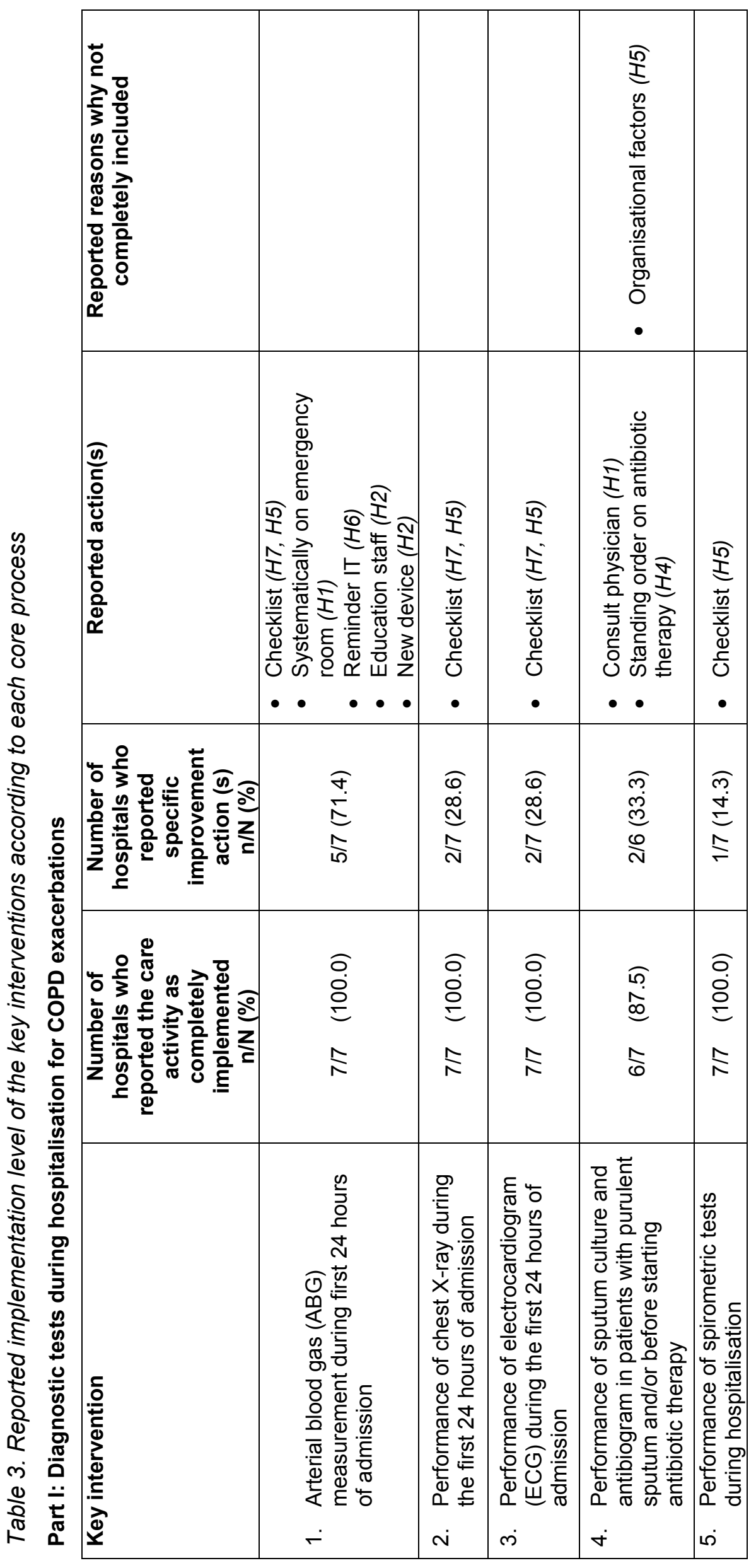




\begin{tabular}{|c|c|c|c|c|c|c|c|c|}
\hline 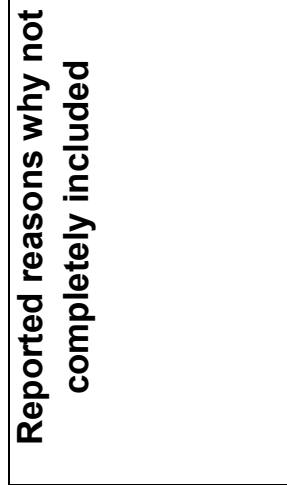 & & 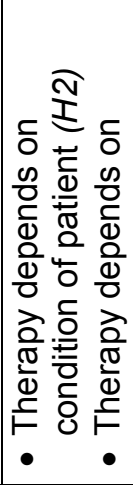 & 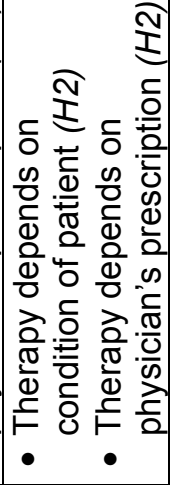 & & & 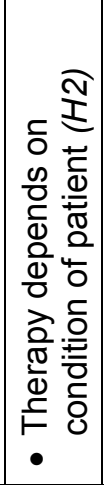 & 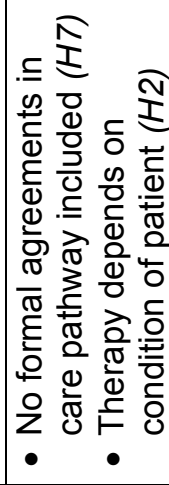 & 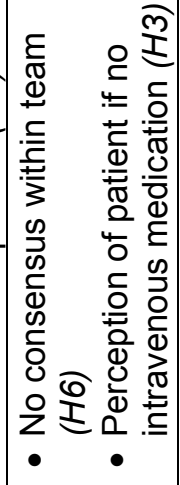 \\
\hline 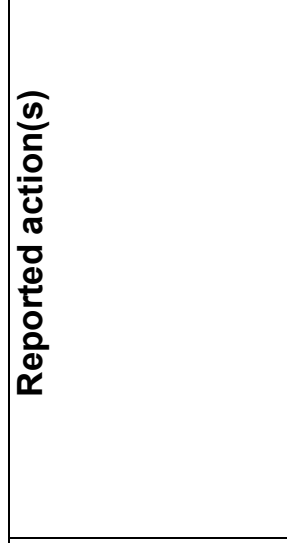 & 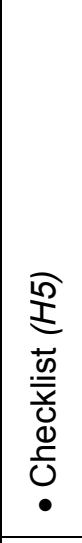 & 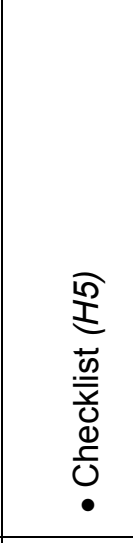 & 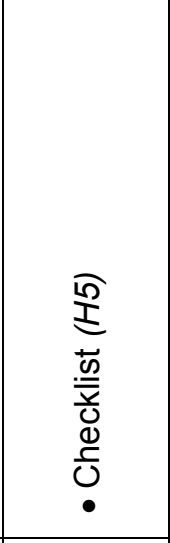 & 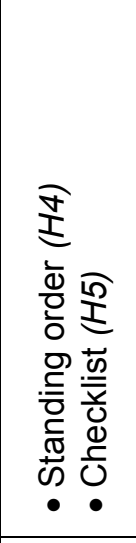 & 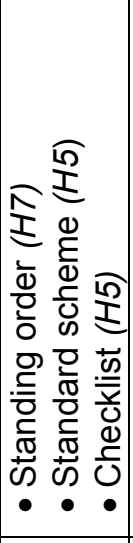 & 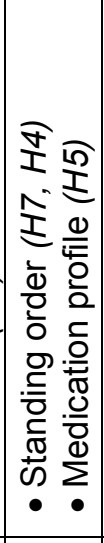 & 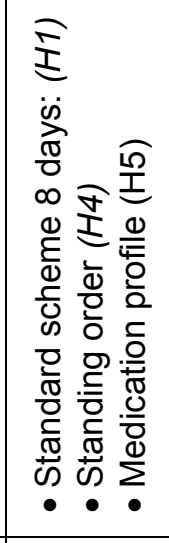 & 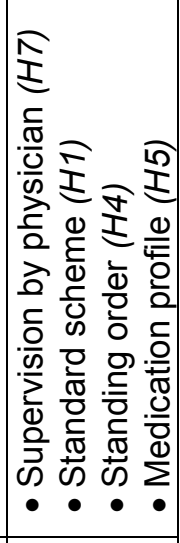 \\
\hline 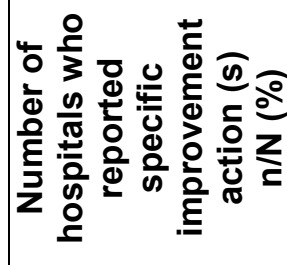 & 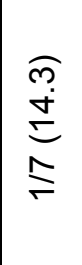 & $\begin{array}{l}\underset{\hat{T}}{\omega} \\
\stackrel{0}{\sigma} \\
\stackrel{0}{\sigma}\end{array}$ & $\begin{array}{l}\underset{T}{\omega} \\
\stackrel{0}{\sigma} \\
\stackrel{0}{\sigma}\end{array}$ & 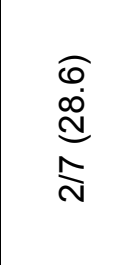 & $\begin{array}{l}\stackrel{\widehat{D}}{\mathrm{~N}} \\
\frac{\mathfrak{J}}{\mathrm{N}}\end{array}$ & $\begin{array}{l}\widehat{0} \\
\stackrel{0}{0} \\
\stackrel{0}{0} \\
\stackrel{0}{m}\end{array}$ & $\begin{array}{l}0 \\
0 \\
0 \\
\frac{0}{0} \\
m\end{array}$ & $\begin{array}{l}\widehat{\partial} \\
\stackrel{0}{0} \\
\infty \\
\frac{\infty}{\gamma}\end{array}$ \\
\hline 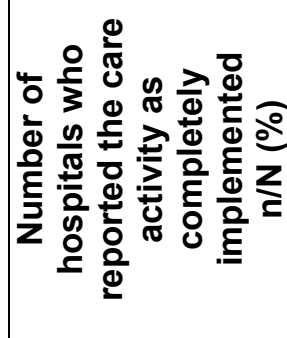 & 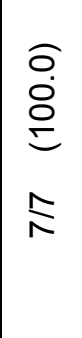 & $\begin{array}{l}\widehat{\widehat{D}} \\
\dot{\infty} \\
\infty \\
\hat{\sigma}\end{array}$ & $\begin{array}{l}\hat{\widehat{T}} \\
\stackrel{1}{0} \\
\infty \\
\hat{\sigma}\end{array}$ & $\begin{array}{l}\widehat{0} \\
\stackrel{8}{0} \\
\stackrel{ }{=} \\
\stackrel{N}{N}\end{array}$ & 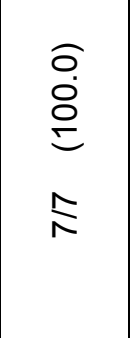 & $\begin{array}{l}\widehat{\widehat{c}} \\
\dot{\rho} \\
\infty \\
\hat{\sigma}\end{array}$ & 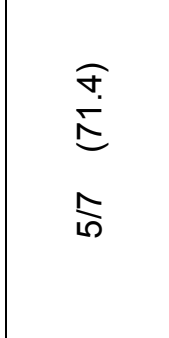 & 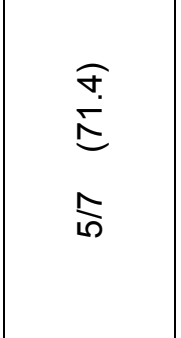 \\
\hline 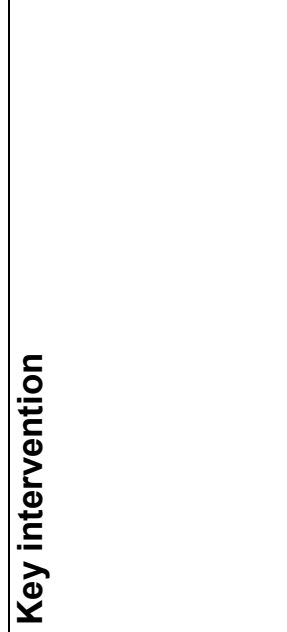 & 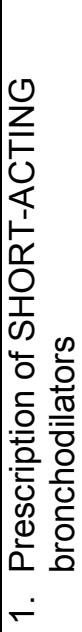 & 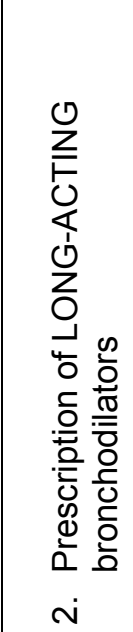 & 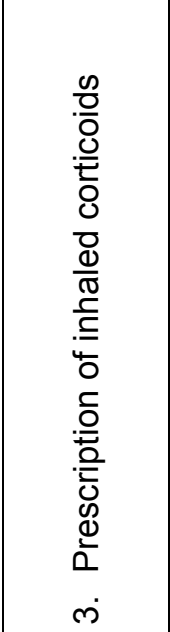 & 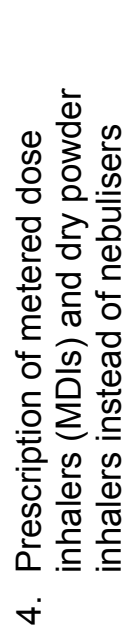 & 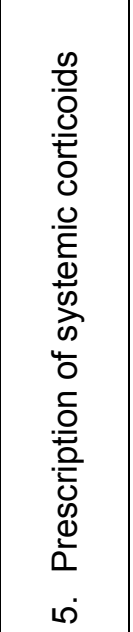 & 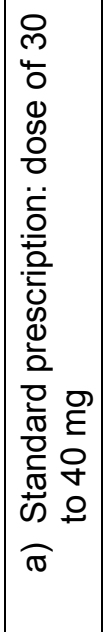 & 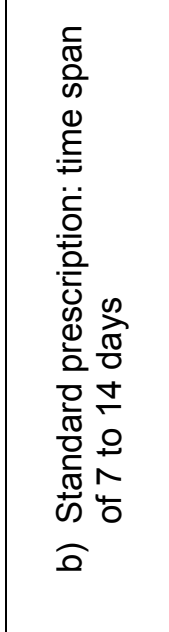 & 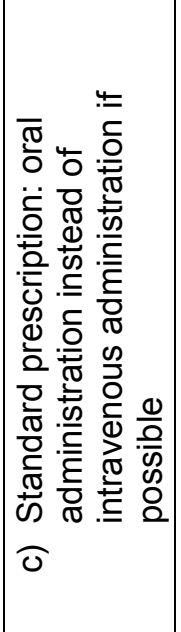 \\
\hline
\end{tabular}




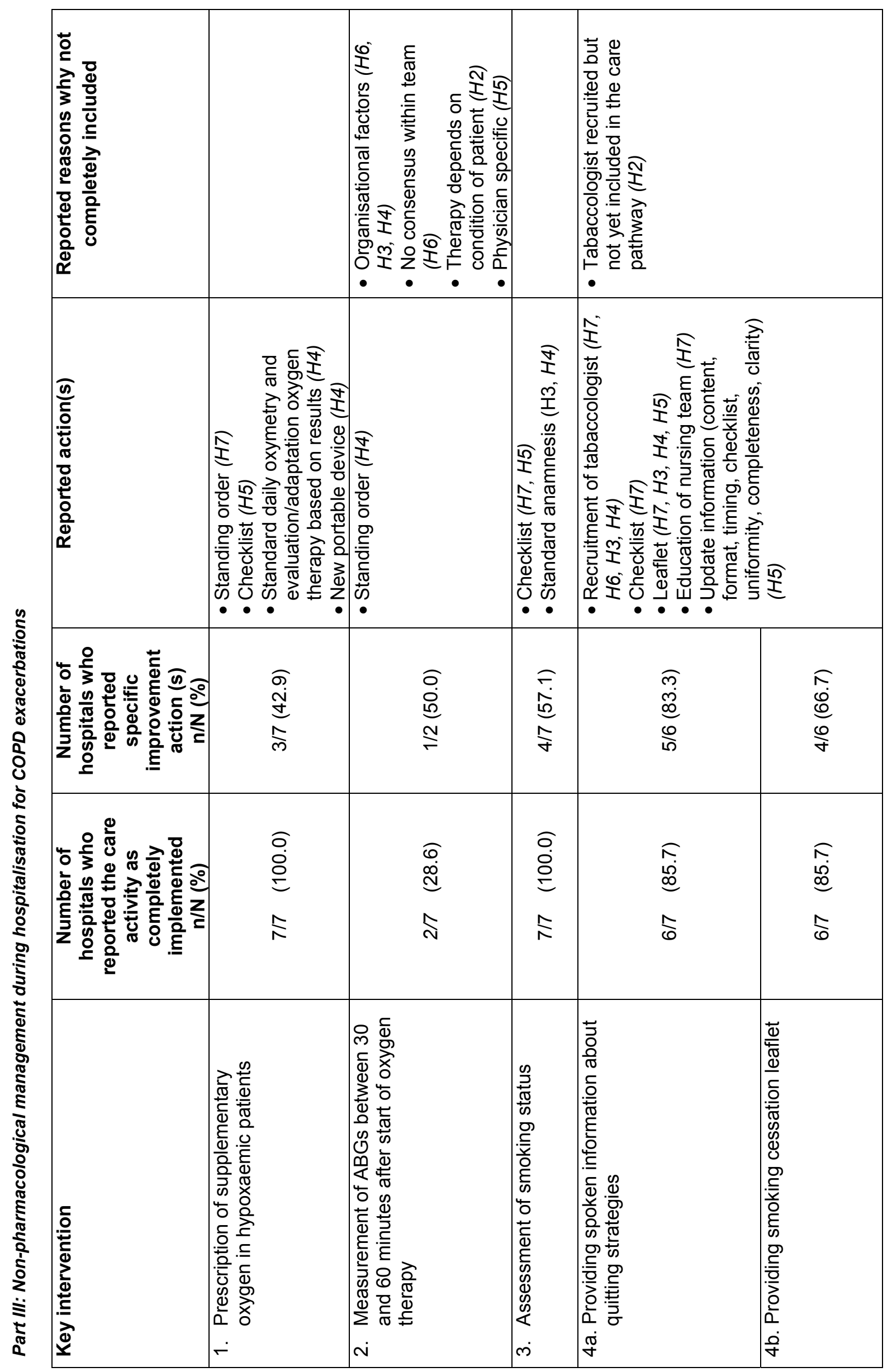




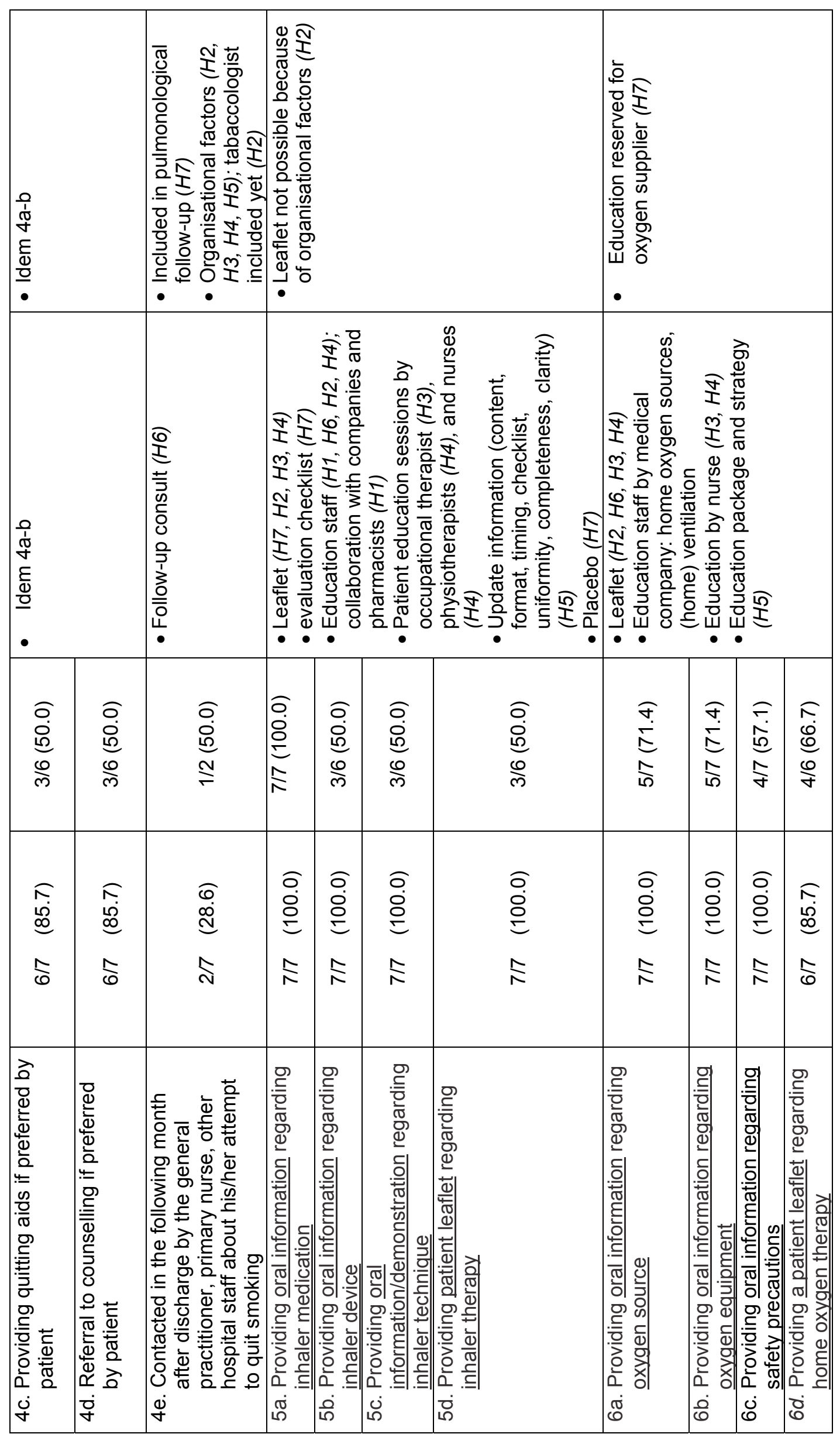




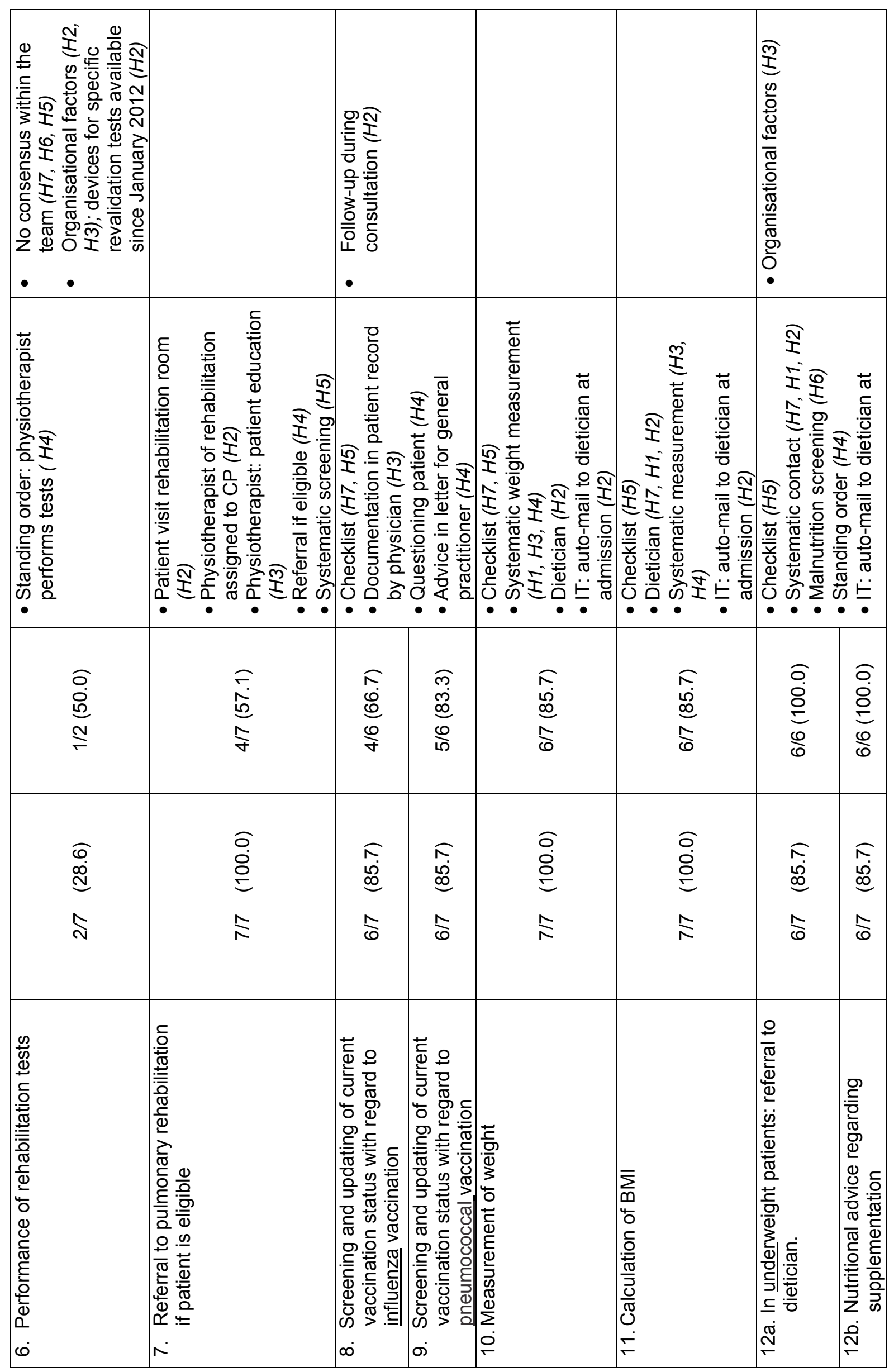




\begin{tabular}{|c|c|c|c|c|c|c|c|c|c|}
\hline & 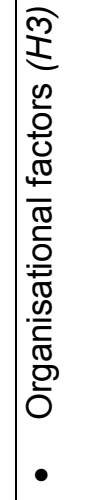 & & 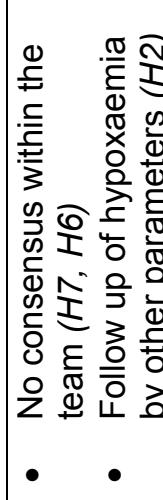 & & 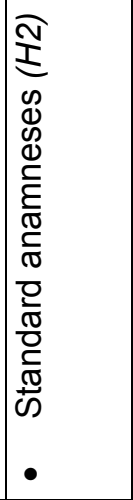 & 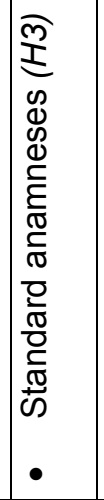 & & & \\
\hline 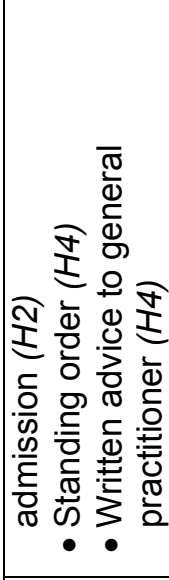 & 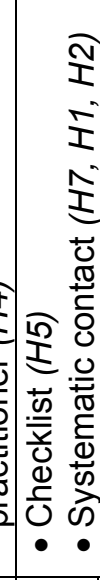 & 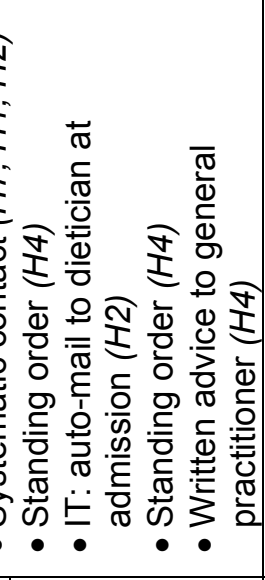 & 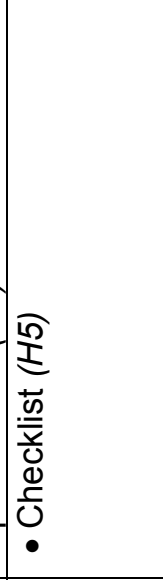 & 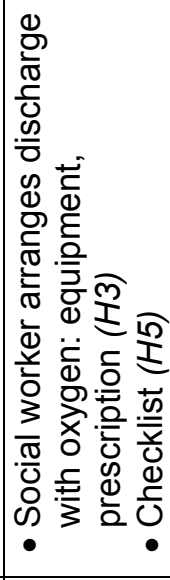 & 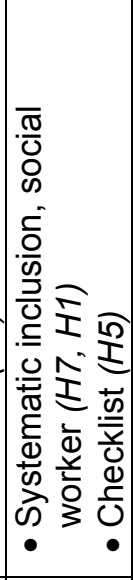 & 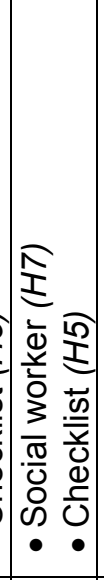 & 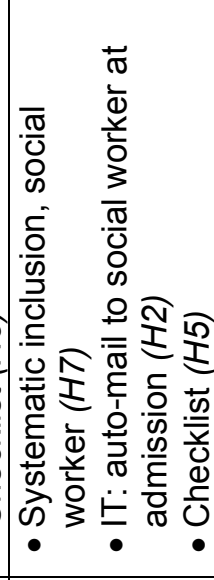 & 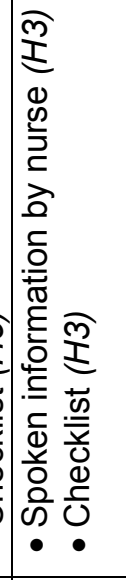 & 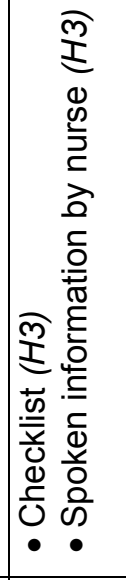 \\
\hline 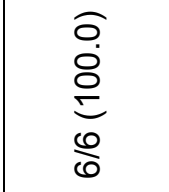 & $\begin{array}{l}\widehat{0} \\
\tilde{\infty} \\
\infty \\
\frac{0}{\omega} \\
\omega\end{array}$ & 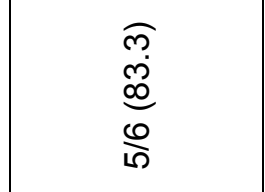 & $\begin{array}{l}\underset{0}{0} \\
\stackrel{\leftrightarrow}{\mathbb{N}} \\
\stackrel{ \pm}{\sim}\end{array}$ & $\begin{array}{l}\widehat{0} \\
\stackrel{0}{\mathfrak{N}} \\
\stackrel{N}{\mathrm{~N}}\end{array}$ & 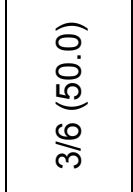 & $\begin{array}{l}\widehat{m} \\
\stackrel{m}{m} \\
\stackrel{0}{\sim}\end{array}$ & 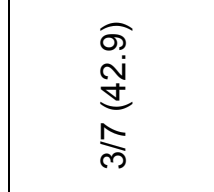 & 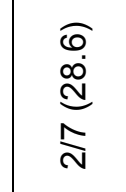 & $\begin{array}{l}\widehat{0} \\
\stackrel{0}{N} \\
\stackrel{N}{N} \\
\stackrel{N}{N}\end{array}$ \\
\hline $\begin{array}{l}\widehat{\widehat{C}} \\
\dot{\infty} \\
\infty\end{array}$ & $\begin{array}{l}\widehat{\widehat{C}} \\
\dot{L} \\
\infty \\
0\end{array}$ & $\begin{array}{l}\widehat{\widehat{T}} \\
\text { மீ } \\
\stackrel{0}{0}\end{array}$ & 厄. & $\begin{array}{l}\text { o̊ } \\
\stackrel{8}{\circ}\end{array}$ & $\begin{array}{l}\widehat{\widehat{L}} \\
\stackrel{0}{0} \\
\stackrel{0}{ }\end{array}$ & $\begin{array}{l}\widehat{\hat{N}} \\
\stackrel{\infty}{\infty} \\
\stackrel{\infty}{ }\end{array}$ & 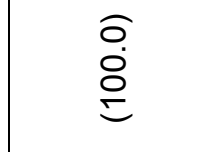 & $\begin{array}{l}\text { ọ } \\
\stackrel{8}{=}\end{array}$ & $\begin{array}{l}\text { ọ } \\
\text { 을 }\end{array}$ \\
\hline$\frac{1}{6}$ & $\frac{1}{6}$ & $\frac{1}{6}$ & $\hat{\gamma}$ & $\stackrel{N}{N}$ & $\frac{\hat{\sigma}}{6}$ & $\frac{\hat{\sigma}}{6}$ & $\frac{N}{N}$ & $\stackrel{N}{N}$ & $\stackrel{N}{N}$ \\
\hline 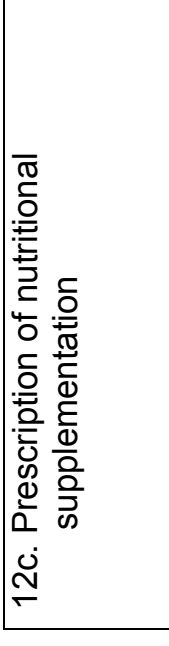 & 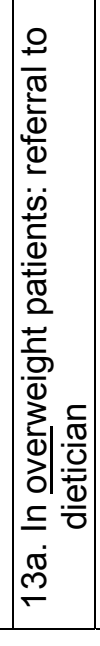 & 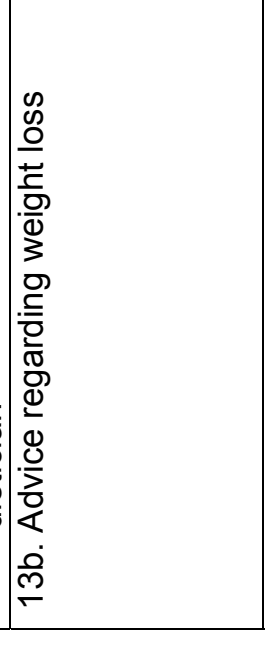 & 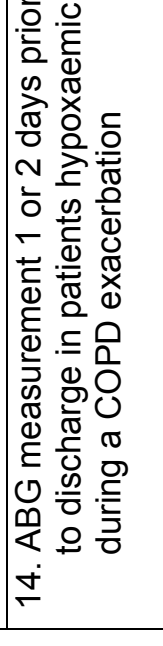 & 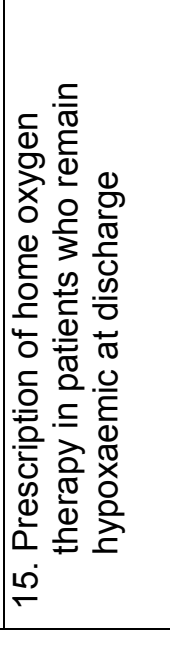 & 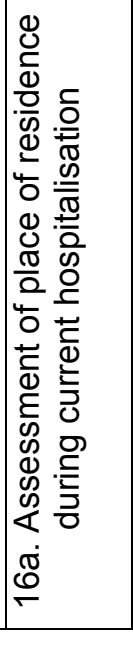 & 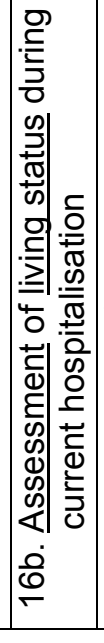 & 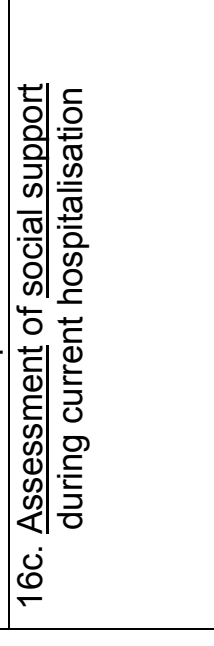 & 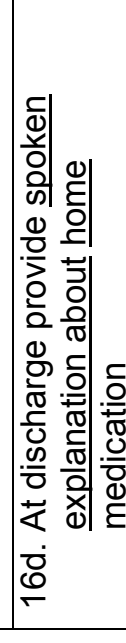 & 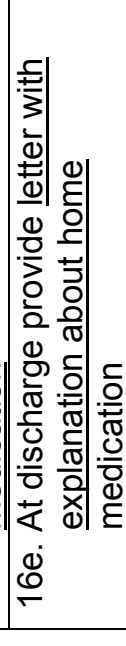 \\
\hline
\end{tabular}




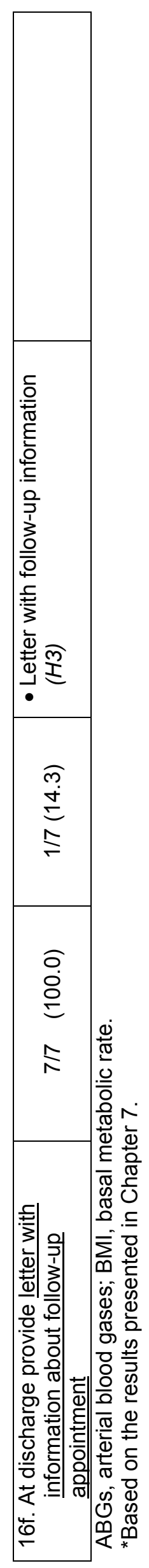




\section{Discussion}

\section{Overall results}

Implementation level of 48 care activities for in-hospital management was evaluated in seven hospitals by means of self-reporting questionnaires. Overall, teams evaluated the care activities as highly implemented, with $\mathbf{8 7 . 5 \%}$ of care activities reported as fully implemented in six to all seven hospitals (Table 2).

\section{Methodological strengths and limitations}

This high reported implementation level of the key interventions may reflect the effectiveness of the 'feedback strategy' described in Chapter 6 [8]. When looking at the applied improvement actions, it turns out that teams applied most actions for the care activities showing the most room for improvement according to the clinical audit before care pathway implementation. These included smoking cessation, education, nutrition, and referral to rehabilitation (Table 3). These findings strongly suggest that understanding bottlenecks appears to motivate teams to improve their actual care process. Thus, feedback on actual performance seems to be a strong and active component in care pathway implementation [15-18].

Another determining factor for the high reported implementation level in this study may be that, since 2000, several rigorous, evidence-based clinical practice guidelines (CPGs) on optimal assessment and management of patients with COPD have been established worldwide [19]. As a consequence, it is assumed that COPD teams are familiar with this rigorous evidence on COPD management, and therefore provide best practice for at least a number of these 38 key interventions. This assumption implies that not all 38 interventions need to be newly implemented or optimised. However, as shown by the clinical audit (feedback on actual care process) and the results of the Belgian EQCP study (Chapter 7), there is a considerable number of these evidence based interventions that are suboptimally performed. Each team should focus their improvement efforts on the key interventions that were suboptimally performed in their organisation.

An important challenge in conducting a CRCT is delivering a standardised intervention in the different sites under study [2;6;20;21]. The high implementation level reported is favourable with regard to standardisation of the intervention. Interestingly, as reflected in the different care pathway documents from each organisation, the care pathways developed in the different sites were not identical because of organisational adaptations at the sites. However, this finding is considered to be beneficial, as complex interventions may work best if they are tailored to local context rather than being completely standardised, provided that the core elements of the interventions (i.e. set of key interventions) are maintained [6;22]. 
For non-pharmacological interventions, several improvement actions referred to the care activity itself (i.e. dietician [Table 3, Part 3, no. 12] and patient leaflet [Table 3, Part 3, no. 6a] and did not describe so-called improvement actions. However, an interview with the study coordinator responsible for two included hospitals indicated that the reported actions referred to newly implemented measures. In addition, we expected to find improvement actions like multidisciplinary team meetings; meetings with other services such as emergency room, lung function services, and radiology (e.g. reserving time slots for diagnostic assessments like chest X-rays or ECGs); and time allocation for specific time-consuming tasks like education of patients [23;24]. It is highly plausible that such actions were undertaken, but were not specifically reported by the study coordinators or team members who were involved in completing the questionnaires.

The most reported reason for non-inclusion or partial inclusion of the key interventions was "organisational factors", which were reported 21 times for 15 different care activities (Table 3). Unfortunately, detailed descriptions of the nature of the organisational issues were provided in only two cases, including 'no tabaccologist recruited yet' and 'devices for rehabilitation tests purchased recently' (Table 3, Part III). In addition, the reason "no consensus within the team" was reported seven times for four different interventions: oral administration of corticoids, ABG measurement after start of supplemental oxygen, $A B G$ measurement before discharge in hypoxaemic patients, and performance of rehabilitation tests (Table 3, Part III). Also here, no further details on the nature of disagreement within the team were reported.

Although this process analyses revealed lots of interesting information, we acknowledge that in future process analyses, it is recommendable to include answer categories like 'multidisciplinary meetings' and 'communication with other disciplines', and to ask team members to explicitly describe the nature of reported action and barriers. Moreover, we believe that conducting structured interviews instead of using mailed questionnaires could have provided more in-depth information on improvement actions and implementation barriers. On the other hand, mailed questionnaires provide the opportunity for the study coordinator to present the questionnaire to different team members for feedback or to organise a team meeting to discuss the different items. In conclusion, we believe that the mailed questionnaires should be combined with an additional interview of the different study coordinators and teams. Alternatively, we recommend organisation of a workshop where all teams are invited to exchange more in-depth information on applied improvement actions. 


\section{Implementation level versus study results: first interpretation}

In this section, preliminary results on the process indicators of the Belgium component of the EQCP study (Chapter 7) will be linked to the results of the implementation analysis. According to the principles of randomisation, experimental group results during formative evaluation and control group results during summative evaluation should be identical. Indeed, in the present study, both groups were highly comparable for almost all indicators, except for adequate prescription of bronchodilators (Formative: $55.9 \%$; summative: $97.0 \%$ ). As a consequence, results of the summative evaluation will be correlated with the implementation analyses.

Overall, the findings indicate that organisations improved most with regard to process indicators with the highest reported implementation level and most reported improvement actions. Highest improvement levels were found for smoking cessation, education on inhaler and home oxygen therapy, and nutritional management (Table 3, Part III, nos. 4a-4d, 5a-6d, 10-13b; Chapter 7, Table 2, nos. 12,13, 14, 17-19). Also to be expected, all care activities with lower reported implementation levels, like $A B G$ measurement before discharge and performance of rehabilitation tests, showed no improvement (Table 3, Part I, no. 1; Part II, no. 5b; Part III nos. 2, 4e, 6, 14; Chapter 7, Table 2, nos. 8b, 15, 22).

Overall, the high implementation levels reported do not correspond with the postimplementation process indicator results (Chapter 7, Table 2), where suboptimal performance was still found for a considerable number of indicators. These findings suggest that the teams may have overestimated their own implementation level. Therefore, it will be interesting to perform additional interviews with team members to gain more in-depth information on the improvement actions they applied and any barriers against implementation they experienced. In this context it would also be useful to obtain more objective information on the implementation level of key interventions through direct observations of independent observers [1].

Regardless of the risk for overestimation of implementation level, this kind of implementation analysis is considered to be very useful for two main reasons. Firstly, this analysis allows us show teams existing discrepancies between high reported implementation levels and suboptimal performance of the particular key interventions. Consequently, this discrepancy might sensitize the teams that further improvements and actions are necessary. Secondly, these analysis will provide other COPD teams, intended to implement the care pathway intervention, with valuable information about potential improvement actions and possible barriers for implementation. 


\section{Conclusions}

The set of 38 evidence-based key interventions was reported as highly implemented in the seven experimental hospitals, which is favourable for the standardisation of the care pathway intervention in different sites. However, despite high reported implementation levels, performance levels of key interventions were not optimal for over half of the indicators. This discrepancy between perceived implementation level and performance results may indicate that the teams may have overestimated their own implementation level, and that the intervention is not yet routinely deployed in daily practice. Additional interviews and direct observations are recommended to obtain more in-depth information on implementation level, improvement actions and implementation barriers.

This process evaluation may also contribute to the second phase of the EQCP study, in which an attempt will be made to describe the relationships between care process structure, multidisciplinary team processes, and outcomes.

\section{Acknowledgements}

We acknowledge the support of the Clinical Research Fund of UZ Leuven, Belgium. We also gratefully acknowledge Pfizer Belgium, Pfizer Italy, Pfizer Ireland, and Pfizer Portugal, who supported this research by providing an unrestricted educational grant. The autonomy of EP-A and all involved academic institutions with regard to scientific independence and intellectual property on methodology is guaranteed. 


\section{References}

1 Hulsher M, Laurant M, Grol R. Process evaluations of change interventions. In Grol R, (ed): Improving patient care: the implementaton of change in clinical practice. Londen, Elsevier Limited, 2005, pp 256-272.

2 Oakley A, Strange V, Bonell C, Allen E, Stephenson J. Process evaluation in randomised controlled trials of complex interventions. BMJ 2006;332:413-416.

3 May C, Finch T, Mair F, Ballini L, Dowrick C, Eccles M, Gask L, MacFarlane A, Murray E, Rapley T, Rogers A, Treweek S, Wallace P, Anderson G, Burns J, Heaven B. Understanding the implementation of complex interventions in health care: the normalization process model. BMC Health Serv Res 2007;7:148.

4 Schneider M, Hall WJ, Hernandez AE, Hindes K, Montez G, Pham T, Rosen L, Sleigh A, Thompson D, Volpe SL, Zeveloff A, Steckler A. Rationale, design and methods for process evaluation in the HEALTHY study. Int J Obes (Lond) 2009;33 Suppl 4:S60-S67.

5 Rychetnik L, Frommer M, Hawe P, Shiell A. Criteria for evaluating evidence on public health interventions. J Epidemiol Community Health 2002;56:119-127.

6 Medical Research Council (2008). Developing and evaluating complex interventions: new guidance, 2008.

[http://www.mrc.ac.uk/Utilities/Documentrecord/index.htm?d=MRC004871]

7 Saunders RP, Evans MH, Joshi P. Developing a process-evaluation plan for assessing health promotion program implementation: a how-to guide. Health Promot Pract 2005;6:134-147.

8 Vanhaecht K, Sermeus W, Peers J, Lodewijckx C, Deneckere S, Leigheb F, Decramer M, Panella M. The impact of care pathways for exacerbation of Chronic Obstructive Pulmonary Disease: rationale and design of a cluster randomized controlled trial. Trials 2010;11:111.

9 Celli BR, Macnee W. Standards for the diagnosis and treatment of patients with COPD: a summary of the ATS/ERS position paper. Eur Respir J 2004;23:932-946.

10 Global Initiative for Chronic Obstructive Lung Disease (GOLD). Global strategy for the diagnosis, management, and prevention of chronic obstructive pulmonary disease, updated 2010. [http://www.goldcopd.org/guidelines-global-strategy-for-diagnosismanagement.html]

11 Lodewijckx C, Sermeus W, Panella M, Deneckere S, Leigheb F, Troosters T, Boto P, Mendeze R, Decramer M, Vanhaecht K. Quality indicators for in-hospital management of exacerbation of chronic obstructive pulmonary disease: results of an international Delphi study. J Adv Nurs. 2012. [Epub ahead of print]. 
12 National Institute for Health and Clinical Excellence (NICE). Chronic obstructive pulmonary disease - Management of chronic obstructive pulmonary disease in adults in primary and secondary care; 2010. [http://guidance.nice.org.uk/CG101]

13 Lodewijckx C, Sermeus W, Vanhaecht K, Panella M, Deneckere S, Leigheb F, Decramer M. Inhospital management of COPD exacerbations: a systematic review of the literature with regard to adherence to international guidelines. J Eval Clin Pract 2009;15:11011110.

14 McKenna HP. The Delphi technique: a worthwhile research approach for nursing? J Adv Nurs 1994;19:1221-1225

15 Pearson SD, Goulart-Fisher D, Lee TH. Critical pathways as a strategy for improving care: problems and potential. Ann Intern Med 1995;123:941-948.

16 Vanhaecht K, Deneckere S, Van Gerven E, Lodewijckx C, Janssens I, Van Zelm R, Boto P, Panella M, Biringer E, Sermeus W. The 7-phase method to design, implement and evaluate care pathways. Intl J Pers Cent Med 2011. In press.

17 Harkleroad A, Schirf D, Volpe J, Holm MB: Critical pathway development: an integrative literature review. Am J Occup Ther 2000;54:148-154.

18 Institute of Medicine. Taking the first steps; in Institute of Medicine, (ed): Crossing the quality Chiasm. Washington, DC 20418, National Academy Press, 2001, pp 39-60.

19 Pierson DJ. Clinical practice guidelines for chronic obstructive pulmonary disease: a review and comparison of current resources. Respir Care 2006;51:277-288.

20 Medical Research Council (MRC): Cluster Randomised Trials: Methodological and ethical considerations. Medical Research Council (MRC) 2002.

[http://open.mrc.gm/Statsdatamgt/stats\&datam_files/MRCguide_cluster.pdf]

21. Vanhaecht K, Ovretveit J, Elliott MJ, Sermeus W, Ellershaw J, Panella M: Have we drawn the wrong conclusions about the value of care pathways? Is a Cochrane review appropriate? Eval Health Prof 2012;35:28-42.

22. Campbell MJ, Donner A, Klar N. Developments in cluster randomized trials and Statistics in Medicine. Stat Med 2007;26:2-19.

23. Cahill NE, Heyland DK. Bridging the guideline-practice gap in critical care nutrition: a review of guideline implementation studies. JPEN J Parenter Enteral Nutr 2010;34:653659.

24. Clarke CM, Persaud DD. Leading clinical handover improvement: a change strategy to implement best practices in the acute care setting. J Patient Saf 2011;7:11-18. 
Chapter 9:

General discussion and recommendations 


\section{Introduction}

The care process for patients hospitalised with chronic obstructive pulmonary disease (COPD) exacerbations is complex [1-5]. Care pathways have become a very popular strategy for improving care processes and optimising outcomes [6;7]. However, until now it is unclear whether care pathways actually work and what active components are responsible for their effect [6;8-11].

The research comprising this $\mathrm{PhD}$ dissertation examined the impact of a care pathway for COPD exacerbations on care processes and clinical outcomes. This was achieved by developing new methodology and by analysing and presenting interim results from an international cluster randomised controlled trial (CRCT).

For this chapter, the main results of this dissertation are presented first, organised according to the six research questions formulated in Chapter 1. Secondly, methodological limitations are discussed. Thirdly, implications for the organisation of COPD care are formulated, and recommendations for future research are addressed. Finally, overall conclusions of the $\mathrm{PhD}$ dissertation are presented.

\section{Contributions to the field of COPD care and healthcare organisation}

RQ1: What is the level of adherence to international guidelines with regard to care processes for in-hospital management of COPD exacerbation according to the literature?

A systematic literature review conducted to explore in-hospital management of COPD (Chapter 2) showed that adherence to guidelines is low, with non-performance ranging from $15 \%$ up to $80 \%$ [12]. Non-pharmacological interventions were especially poorly performed, such as those involving smoking cessation, rehabilitation, education, nutrition, and discharge management. Clearly from this review, further research on process adherence is needed, as measured indicators from different published studies varied widely and compliance to nonpharmacological processes was scarcely assessed.

\section{RQ2: What is the impact of existing care pathways for in-hospital management according to the literature?}

A systematic literature review identified only four pertinent studies. This handful of studies suggested that care pathways might have positive effects on diagnostic and nonpharmacological processes. However, due to limited statistics, divergent measures, and evaluation of a care pathway by means of a historical control group, it must be concluded that the internal validity of results from these studies is limited. Hence, strong conclusions 
about the impact of COPD care pathways could not be confidently drawn on the basis of these four published studies.

RQ3: Which indicators should be followed up when evaluating the impact of a care pathway for COPD exacerbations?

A set of 24 process and 15 outcome indicators was developed [13] based on literature, an international Delphi survey, and face-to-face discussions with experts in the field. These indicators refer to care activities and clinical outcomes that, according to the literature, are suboptimally performed and show high variability across different hospitals [12;14;15]. These findings suggest that the selected indicators have potential for improvement when being used to study the impact of interventions aimed at improving performance of COPD care processes and clinical outcomes [16]. Furthermore, indicators were piloted in nine Belgian hospitals, and measurements were determined as feasible by different involved parties.

\section{RQ4: Which set of key interventions should be included in a care pathway for COPD exacerbations?}

Within this dissertation work, we developed an eight-step method for designing the clinical content of a care pathway based on acknowledged design and guideline development methods (Chapter 5, Figure 1). By using this eight-step method, a set of 38 evidence-based key interventions was developed (Chapter 5, Appendix 1). The key interventions were categorised into three main processes (diagnostic, pharmacological, and nonpharmacological management), and then formulated into a process flow diagram. Every key intervention was described in detail, including the rationale, description, references, and grading of evidence. The set of key interventions were studied and approved by nine multidisciplinary COPD teams. The new eight-step method will likely help teams in shaping the clinical content of their future evidence-based care pathways aimed at other diseases and conditions, such as hip fracture, heart failure, and diabetes.

\section{RQ5: What is the impact of a care pathway for in-hospital management of COPD exacerbations on performance of care processes and clinical outcomes?}

In 2009, the European Quality of Care Pathways (EQCP) study, an international cRCT, was launched in four countries (Belgium, Ireland, Italy, and Portugal), with two aims: (i) to study the impact of a care pathway for in-hospital management of COPD exacerbations on care processes, clinical outcomes, and teamwork; and (ii) to investigate why and under what circumstances care pathways are effective $[17 ; 18]$. In total 65 hospitals were included. Thirtythree hospitals were randomised to the experimental group, which implemented a care pathway, while the remaining 32 hospitals were randomised to the control group, which 
provided usual care. The care pathway included three active components: (i) feedback on actual performance, (ii) integration of evidence-based key interventions in daily care, (iii) training on care pathway development and implementation.

This work conducted for the author's PhD was included as part of the larger EQCP study and focussed on the first study objective: impact of care pathways for in-hospital management of COPD exacerbations on care processes and clinical outcomes. The EQCP study in Belgium is one year ahead of the other countries (Ireland, Italy, and Portugal) and is also considered to be a pilot test. Because of timing and feasibility of carrying out the PhD work, only the results of the Belgian EQCP study are included in the results section of this dissertation. Final results comprising data of all four countries are expected to be analysed in autumn 2013 and will be disseminated by the EQCP study group via publications and conference proceedings in 2013 and 2014.

Seven experimental and five control hospitals were included in the Belgian EQCP study. Analyses showed that performance of process indicators improved $10-50 \%$ in the care pathway group for 7 of 24 indicators $(29.2 \%)$ and 25 of 42 subcomponents $(59.5 \%)$, most improvements coming from activities associated with education, nutrition, administration of corticoids, and discharge management. Statistical significance was found for only three indicators and ten subcomponents. This was to be expected because data from only the Belgian hospitals were used, which led to a small sample size and hence low statistical power. However, criteria to meet for every process indicator is $100 \%$ performance, regardless of patient characteristics. Consequently, results on the process indicators, in this case better performance up to $50 \%$ in the care pathway group, do reflect the performance level of the teams, and so should not be considered to be coincidental results arising from chance variation in small samples.

Interesting but also expected, for the outcome indicators we found no significant results, though considerable non-significant improvements were found for 30-day readmission (care pathway: $13.6 \%$ vs. usual care: $22.2 \%$ ) and length of stay (LOS) (care pathway: 11.65 days vs. usual care: 14.49 days).

Results of the EQCP study in Belgium suggest that implementation of a COPD care pathway can improve performance of care processes and has the potential to positively affect clinical outcomes. However, because of limited statistical power, especially for outcome indicators, conclusions on effectiveness can only be confidently drawn when results of the total sample of the four countries become available. It is promising, however, that the hospitals who implemented a care pathway showed higher performance levels with a 10$50 \%$ increase. In the care pathway group, however, suboptimal performance of less than $50 \%$ was found for 12 of 24 indicators $(50.0 \%)$ and for 8 of 42 evaluated subcomponents 
(19.0\%). In conclusion, we see the need for a continuous quality improvement approach to achieve normalisation and thus optimal performance of the processes.

One strength of the EQCP study is that it is designed as both a research study and a quality improvement project. The involved teams receive support in the reorganisation of care for COPD patients, and they can later use the knowledge they gained in other care processes. To illustrate, experimental teams stated in interviews conducted for the parallel EQCP trial on teamwork [19], that they considered this project to be one of the best improvement projects they had ever participated in, especially because of the combination of the three components of care process auditing, integration of evidence-based knowledge, and structured support in care pathway development and implementation. As a result of this study, the involved organisations were chosen to become centres of excellence in the organisation of care processes and will function as examples of good practice on the national and international level for professionals and hospital managers aiming to improve the quality of their care [17]. This network will support other organisations currently not involved in the EQCP study in the optimisation and evaluation of their own care processes [18].

The EQCP methodology, which was designed according to the framework for complex interventions by a team of experts with widely recognised experience in care pathways, may guide other researchers when implementing and evaluating a care pathway or other complex intervention using a cluster randomised design. Before the launch of the EQCP study, only five cRCTs on care pathways had been conducted, all performed on national level [20-24]. The EQCP study is the first international CRCT to study care pathway effectiveness [17], and therefore it will provide new knowledge on design and performance of a cross-border CRCT, which can pose a major challenge due to logistic, economic, and cultural issues. Finally, previous studies on care pathways focussed on the integration of a set of key interventions as a main active component. This is the first study on care pathway effectiveness that includes the additional components of feedback on actual performance and the training of teams on development and implementation of care pathways.

\section{RQ6: What is the level of implementation of the key interventions included as active components in the care pathway for in-hospital management of COPD exacerbations?}

We used self-reported questionnaires to evaluate 48 care activities for their level of implementation in the seven experimental hospitals (Chapter 8). These activities are related to the set of 24 process indicators and their 42 subcomponents (which are part of the multicomponent indicators). According to the study coordinators and the team members, care activities were highly implemented: 42 of 48 evaluated care activities (87.5\%) were fully implemented in six to all seven hospitals. The number of included care activities for which a 
specific action was reported ranged from $28.6 \%$ to $97.7 \%$ over the seven hospitals, with most actions undertaken for non-pharmacological interventions.

However, the high implementation levels do not correspond with the results on process indicators after implementation, as a considerable number of indicators were still suboptimally performed (Chapter 7 , Table 2). These findings suggest that the teams may have overestimated their own implementation level, and consequently additional measures like interviews and direct observation may be needed to provide more objective information on the implementation process. However, this implementation analyses give teams insight into discrepancies between highly reported implementation levels and subtoptimal performance of the implemented care activities. Consequently, these analyses may sensitise the teams that further improvements and actions are necessary. Furthermore, these analyses will provide important insights to other teams planning to implement the care pathway intervention, especially which regard to potential improvement actions and barriers for implementation.

\section{Overall methodological limitations}

An important limitation with regard to reporting of data in this dissertation is that, because of timing and feasibility, interim analyses were performed on the Belgian data only. Thus, the necessarily small sample size resulted in less-than-desired statistical power, and consequently the chance of finding statistically reliable results was poorer at this interim stage. Nevertheless, as comprehensive addressed in chapter 7, criterion to meet for every process indicator is $100 \%$. Consequently, results on the process indicators do reflect performance levels of the teams, and so should not be considered to be coincidental results arising from chance variation in small samples.

An important point of discussion is patient involvement. In the care pathway intervention in our study, no components for facilitating patient-focused care were included. The Institute of Medicine emphasised the importance of patient centredness, stating that high-quality care should be safe (avoiding patient injuries due to care intended to help them); effective (evidence-based, avoiding underuse and overuse); patient centred (respectful of and responsive to individual patient preferences, needs, and values); timely (no needless delay); efficient (avoiding waste); and equitable (no variation in quality because of person's class) [25]. Moreover, research on patient involvement showed that patients who are actively involved in their care tend to make healthier lifestyle choices, were more likely to adhere to treatment recommendations, showed improved clinical outcomes, and often used fewer healthcare resources [26-29]. 
When examining the literature on patient involvement in COPD patients, we found a very limited number of interesting publications, all addressing COPD-specific preferences and concerns such as 'experiencing breathlessness', 'being housebound', and 'need for medical care'. [30-32]. However, this literature research revealed two interesting frameworks that focussed on identifying and understanding individual needs of patients and establishing patient-centred therapeutic care in COPD patients [33;34]. Furthermore, a brief literature search on patient focused care identified following possible active ingredients for improving patient involvement: (i) decision aids and training of healthcare professionals in communication skills and shared decision making [26;27;35]; (ii) tools and strategies to measure and explore context-related preferences (i.e. waiting, unreliable administrative processes, rude and difficult staff, misunderstandings in communication, handovers) [29]; and (iii) instruments for assessing patient satisfaction during their care process (i.e. conducting surveys, open interviews with patient or relatives, performing walkthroughs with a patient) [36-38]. Furthermore, Jaques et al. indicated that patients should have a broader role in improving care by contributing to policy and major systems design. Involving patients in audit will help in measuring processes and outcomes of real value for patients, not just those that clinicians think are important [29;39]. Finally, we believe that patient societies could play an important role in making our care more patient-focused.

Finally, we need to address that, within the timeframe of this PhD dissertation, no economic evaluation was included. However, health status was followed up by using the Euroqol 5D (http://www.euroqol.org). When all data of the four countries are collected, economic analyses will be performed [40].

\section{Implications for the organisation of COPD care}

Firstly, findings with regard to low adherence to evidence-based guidelines should encourage all multidisciplinary teams and hospital managers to audit and optimise their care process for patients hospitalised with COPD exacerbation.

When optimizing their care process, teams should look into the care pathway strategy as presented and studied in this dissertation. Moreover, teams should pay additional attention to non-pharmacological interventions, as they are very suboptimally performed. Integration of these interventions into daily care may be more difficult for several reasons. (i) Most of these interventions are multicomponent interventions, which are very time-consuming and are difficult to integrate into the wide range of daily clinical tasks (i.e. education on inhaler therapy). (ii) The non-pharmacological interventions are all focussed on long-term outcomes of prognoses, quality of life, coping and self-management, and hence do not provide early and ongoing results of delivered care. (iii) Adequate performance of these interventions 
requires qualified staff with specific competencies-like a tabaccologist, a dietician, and a physiotherapist-and use of specific protocols (in example how to adequately educate a patient regarding inhaler therapy).

One outcome of this dissertation work is a newly developed set of 38 evidence-based key interventions for in-hospital management of COPD exacerbations (Chapter 5), piloted and approved by nine multidisciplinary teams. COPD teams that aim to optimise their care should carefully examine this set of key interventions. The rationale included for each intervention will help leaders motivate their teams to improve performance of the different key interventions. Moreover, the descriptions for each intervention will facilitate their practical integration into daily care, especially for complicated or time-consuming interventions like patient education and discharge management.

Another outcome of this dissertation is a set of 39 quality indicators for in-hospital management of COPD exacerbations, operationalised into objective measurements. COPD teams should audit their care processes for in-hospital management of COPD exacerbations based on this validated and ready-to-use set of indicators. However, follow-up of 39 indicators in daily practice would be impractical. Therefore, we need to make a distinction between research and clinical practice. When conducting research on care pathway effectiveness, in this case a cRCT, the aim is to collect as much evidence and knowledge as possible in order to fill the "blind spots" about care pathway effectiveness. Furthermore, considering that it is challenging to conduct cRCTs due to logistic and economic issues, we believe that the opportunity to collect data in a multicentre study should be fully utilised. In daily practice, however, we recommend that a subset of indicators should be identified for follow-up. Selection should be performed by primary stakeholders (team, managers, etc.), and should be based on following criteria: (i) knowledge of daily practice, referring to processes known or presumed to be suboptimally performed in the organisation and so being targets for improvement; and (ii) the SMART principles [41], referring to the idea that indicators should be Specific (the goal is clear and unambiguous, what knowledge do you want to get out of it); Measurable (are the measurements feasible); Attainable (are the indicators realistic); Relevant (sensitivity to change, interest of stakeholders like team and management), and Timely (timeframe of measurements, when should feedback be available). Furthermore, according to achieved improvements on indicators and input of new evidence based knowledge on the care process, these set of indicators for daily monitoring should be systematically updated according to the criteria mentioned above.

A validated set of indicators also provides important opportunities for benchmarking between organisations, although some barriers need to be considered. As indicated by the literature [12;42] and as highlighted in the report of the Belgian Healthcare Knowledge Centre (KCE) [43], hospitals invest significant time and manpower collecting data for internal 
audits or for delivery to different healthcare institutions, though the use of divergent measure formats does not provide for benchmarking. The KCE report also identified different excellent initiatives on quality indicator development and measurement, though some initiatives tended to overlap, implying unnecessary duplication [43]. We see a leading role for governments to centralise all initiatives and to provide for a global system incorporating standardised indicator sets with standardised measure and feedback formats; these should be usable for internal and external audit and allow for proper benchmarking.

\section{Implications for future research}

\section{Continuation of the EQCP study}

The EQCP study is also being conducted in three other countries: Ireland, Italy, and Portugal. The same study protocol is being used, including implementation of the complex intervention (feedback, evidence-based key interventions, training on care pathway implementation) and follow-up of the same set of quality indicators. However, in the context of differences in professional culture and clinical practice, some minor adjustments needed to be made to the set of key interventions and the quality indicators. Furthermore, the level of expertise in care pathway development and implementation varies considerably in the different countries. In the Belgium study, all participating hospitals were members of the Belgian Dutch Clinical Pathway Network (www.nkp.be) [44]. This means that the study coordinators in the Belgian hospitals were already experienced in pathway development, implementation, and evaluation, which proved to be an enormous advantage, enabling us to easily conduct the study. At the same time, lack of care pathway experience of researchers from the other involved countries needs to be acknowledged. Careful attention with regard to training on care pathway development and implementation will be required in order to ensure that the 'same' experiment is performed across all the participating countries. However, the Italian hospitals, recruited out of the Piedmont region, are more or less familiar with care pathways due to earlier research and initiatives of the Amedeo Avogadro University of Eastern Piedmont. Also, national coordinators and several quality managers of the involved hospitals of Ireland, Italy and Portugal received comprehensive education on care pathway development, implementation, and evaluation during an international summer school (www.E-P-A.org) organised by the European Pathway Association (E-P-A). Moreover, as members of E-P-A, they have access to worldwide networking and regular newsletters, conferences, and additional training on care pathways and organisation of care [7].

The first results of the clinical audit conducted before care pathway implementation are now available for the three other countries involved. Initial observations show that adherence 
to guidelines is comparable to that of the Belgium component of the study. This implies that there is also considerable room for improvement in Ireland, Italy, and Portugal.

It is important to note that Ireland, Italy, and Portugal are currently under great economic pressure. However, this study can be an opportunity for healthcare leaders to leverage the results in economic terms. During economic crises, governments are stressed more than ever to rapidly but effectively reform their healthcare system. Because care pathways are used to standardise care, improve coordination, and optimise outcomes with optimal allocation of resources, policy makers might see this study as a first step in the right direction for healthcare reform. In addition, the research in these three countries may provide more insight into how governments and healthcare systems manage (or tend to manage) an acceptable level of safety and quality in healthcare delivery under economic depression.

In the second phase of the EQCP study, when all data on process, outcome, and team indicators from all four countries are collected [18] and when the results on the parallel trial on teamwork are available [19], we will investigate why and under what circumstances care pathways work [17]. More specifically, we will explore (i) which mechanisms (active ingredients) in care pathways underlie their effect ('what are active components?'), and (ii) the role of contextual factors and multidisciplinary team work when implementing and evaluating care pathways [10;17]. Therefore, we will use the approach described in the Care Process Organisation Triangle, developed by Vanhaecht et al. [45] This approach is based on the Donabedians' structure-process-outcome framework [46], the realistic approach of Pawson and Tilly [10;47], and the terminology used by Heskett et al. [48], Teboul [49], Batalden and Davidoff [50], and Mitchell et al. [51]. This triangular framework describes the relationships between the structure of the care pathway care process, multidisciplinary team processes, and outcomes.

\section{Need for continuous quality improvement}

Implementation of the complex intervention in the seven Belgian hospitals improved performance rates by 10 to $50 \%$. However, in the experimental group assigned to the care pathway, suboptimal performance of less than $50 \%$ was found for 11 of 24 indicators (45.8\%) and for 8 of $42(19 \%)$ evaluated subcomponents. By contrast, the study coordinators and team members reported that almost all interventions were highly implemented. These findings indicate that the experimental teams already adopted the intervention, but that the intervention was not routinely imbedded in everyday practice [52].

There are several possible reasons why routine integration of the intervention (normalisation) was not achieved. Firstly, developing and implementing the intervention according to the Plan Do Study Act (PDSA) cycle was apparently insufficient for reaching 
normalisation within the studied time span. This finding indicates that more PDSA cycles are necessary in order to reach optimal performance. Moreover, a fundamental principle of the PDSA cycle is iteration: Once an hypothesis is supported, executing the cycle again will extend the knowledge further and bring the outcomes closer to the goal, including an improved operation and output [53]. Secondly, the change capacity of the involved teams may also play an important role. More specifically, team competencies, including the knowledge, skills, and attitudes of staff members related to change processes, will be crucial determinants of success $[45 ; 54 ; 55]$. Team effectiveness is strongly driven by local organisational culture. Consequently, change behaviour in clinical practice is not a 'one-shot deal' but is progressive and requires long-term cultural change initiatives [55].

Strongly related to the normalisation process is sustainability, which is defined by the four characteristics of Wiltsey et al. (2012): (i) the extent the core elements are maintained (core elements are the most closely related elements associated with desired health benefits); (ii) the extent desired health benefits are maintained or improved over time after initial funding or supports have been withdrawn; (iii) how strong impact modifications have on the core ingredients of the intervention; and (iv) continued capacity to function at the required level in order to maintain the desired benefits [56]. Long-term effectiveness of care pathways had not yet been evaluated [6;57-61]. Also in the EQCP study, the impact of the care pathways was assessed at a maximum of 6 months after implementation [18]. Interesting, Savits et al. (2000), who described the life cycle of clinical care processes, indicated that clinical processes will reach a critical point in which they could further improve, maintain, or decline [62]. In the 2009 study of Vanhaecht et al., data collected using the Care Process Self Evaluation Tool [63] indicated that the critical point at which improvement slowed down for care pathways was about one year [62;63]. A possible explanation for this slowing was (i) the lack of continuous follow-up of the pathways, and (ii) deterioration of pathway standardisation and coordination [63]. As noted by Goldmann, it is relatively easy to engage a multidisciplinary team in creating a pathway, but it is much harder to motivate members to update it regularly [64]. Many models of sustainability exist but have not been evaluated yet [56]. In conclusion, it will be interesting to explore (i) the critical point for alternative crossroads of improving, maintaining, or declining care pathways, and (ii) possible active ingredients for enhancing sustainability of care pathways.

Based on previous findings, we conclude that a continuous quality improvement (CQI) approach will be necessary to achieve normalisation and subsequent optimal performance, and to maintain sustainability. CQI is operationally defined as a philosophy of continual improvement of a processes associated with providing a good or service that meets or exceeds customer expectations [65]. The emphasis lies on understanding and improving the 
underlying work processes and systems in order to add value rather than on correction of individuals' mistakes after the fact [65].

Using an expert panel that reviewed 161 articles on CQI projects, O'Neill et al. (2009) identified six key features of CQI: (i) iterative development process, (ii) feedback at meetings involving participant leaders, (iii) feedback of systematically collected data, (iv) recognised change method (i.e. Deming approaches), (v) driven by data collected systemically during implementation, and (vi) local conditions considered. However, these authors indicated that only a few articles included all these features. Therefore, future research will be necessary to theorise active ingredients for successful implementation of a CQI intervention [66]. In addition, use of information technologies (ITs) may facilitate embedding of care pathway content and continuous follow-up of care pathways [67;68]. An interesting example of the impact of IT is the clinical management information system used by Intermountain Healthcare in Salt Lake City [67]. Their enhanced IT system provides for a centralized patient database that is accessible for clinicians over the whole geographically dispersed health network, and also includes a data measurement system that captures data on guideline adherence as well as on clinical cost, and service outcomes built around specific clinical care processes [67].

In 1998, Shortell et al. identified the strengths and limitations of the clinical application of CQI. According to their review, successful factors in CQI might be participation of physicians, feedback to individual practitioners, and a supportive culture to maintain the gains that are achieved. Failures were reported because of non-acceptance by local physicians, poor dissemination of knowledge, and vague feedback to practitioners [65]. With regard to existing research on the impact of CQI, Shortell et al. found that relatively few appropriate RCTs are available. Most of the studies are single-centre studies, with a before-and-after design. Hence, it is difficult to determine whether the reported improvements are due to the CQI interventions or to competing explanations [65].

On the basis of previous findings, we decided to start a Belgian clinical working group on in-hospital management of COPD exacerbations, with the aim of (i) assessing sustainability of results, and (ii) improving in-hospital care for COPD patients with exacerbations by using the CQI approach. Follow-up measures will be conducted in the 12 hospitals already included in the EQCP study and in newly recruited organisations of the Belgian-Dutch Clinical Pathway Network (BDCPN). Of the set of 39 process and outcome indicators we developed, a select subset will be followed up and chosen based on the SMART principles [41;52]. Based on initial conclusions of the Belgium EQCP study, important additional emphasis will focus on patient involvement [26;27;35], team training [52;55;69-71], and organisational context $[8 ; 15 ; 54 ; 67 ; 68 ; 72-77]$. 


\section{A new model for care pathways for reorganisation of chronic care [78]}

Future care pathway research should focus on chronic transmural care for several reasons. Firstly, the increasing prevalence of chronic disease represents major challenges for healthcare systems [28;79-81]. It is estimated that $70 \%$ of healthcare expenses are related to chronic diseases [82]. In addition, the current fragile economic climate may progressively limit resources available to healthcare systems [28;79]. Secondly, another challenge lies in the actual organisation of healthcare delivery systems. Current healthcare delivery systems are often unable to meet the complex needs of chronically ill patients because healthcare is traditionally focussed on acute care management and short term goals [83]. Also, fragmented delivery of health and social services, including disconnection of primary and secondary care, is an acknowledged problem in many healthcare systems [28;80;83-85]. Thirdly, too often, chronic care approaches feature an uninformed, passive patient interacting with a poorly coordinated team of health professionals, resulting in frustrating and inadequate encounters [86-88]. Finally, despite the availability of worldwide evidence-based practice guidelines for a wide range of chronic diseases, the use of evidence-based standards remains limited $[79 ; 80 ; 89]$.

A well-established model designed to guide the reorganisation of healthcare delivery systems from acute and reactive care to chronic, proactive, and community-based care is the Chronic Care Model (CCM) developed in 1996 by Wagner et al. [88]. In this systemic model, improved functional and clinical outcomes of disease management are the results of productive interactions between informed, activated patients and prepared, proactive practice teams of healthcare professionals. These productive interactions are supported by six components: healthcare organisation, community resources, self-management support, delivery system design, decision support, and clinical information systems [83]. To better integrate aspects of prevention and health promotion into the $\mathrm{CCM}$, an enhanced version called the Expanded Chronic Care Model was developed in 2003 by Barr et al. [90] (Figure 1).

\footnotetext{
${ }^{1}$ An editorial on this subject is published in the International Journal of Care Pathways, April 2012; 13:1-2.
} 


\section{Figure 2. The Expanded Chronic Care Model [90]}

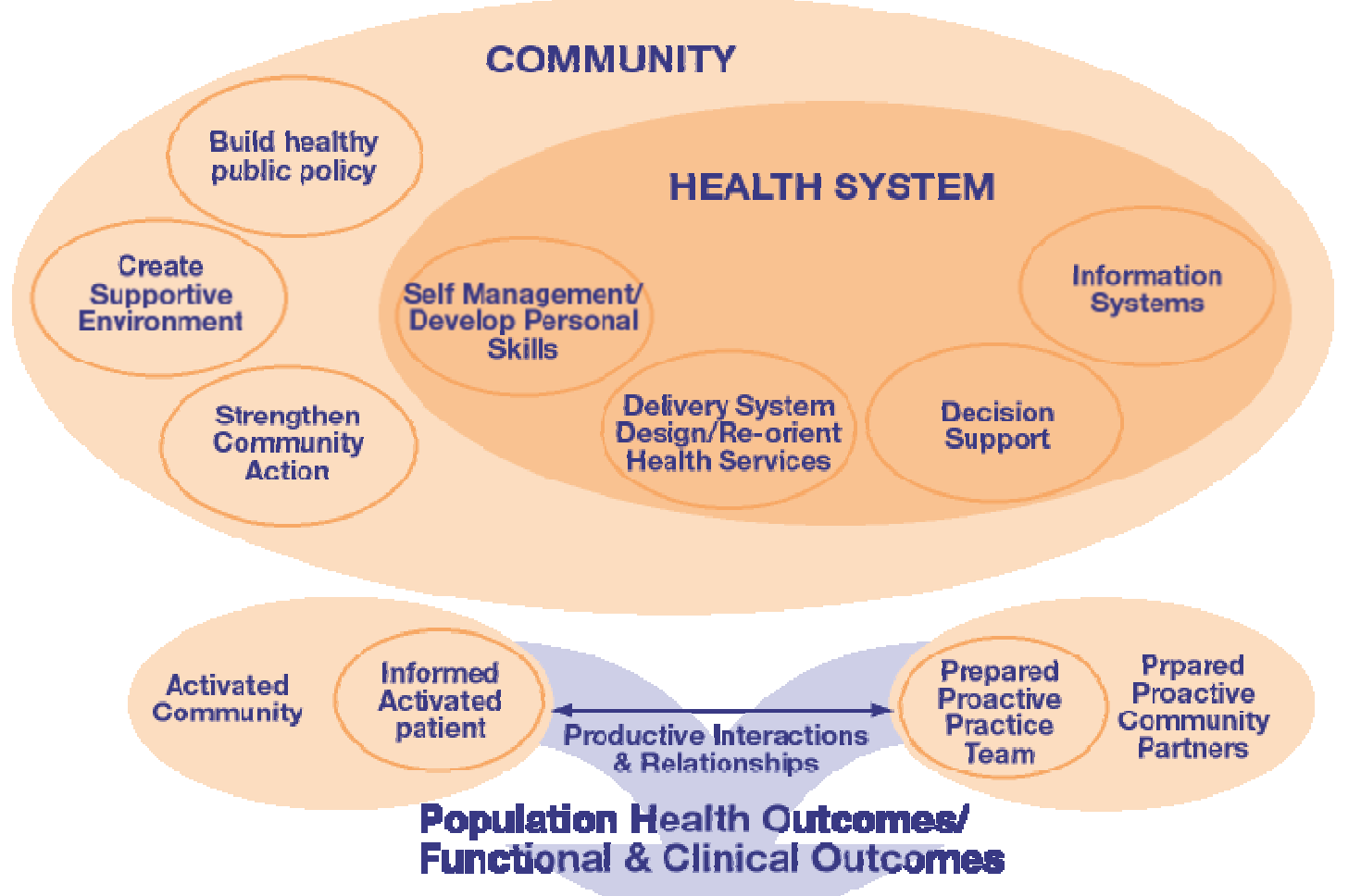

Several attempts have aimed to adequately measure the effectiveness of care reorganisation in the context of the CCM [91;92]. However, because of defragmented implementation, different change strategies, and use of different outcome indicators, effectiveness of reorganising health care delivery systems according to the CCM on patient outcomes and on healthcare costs remains unclear [91-93].

A possible strategy for facilitating integration of the CCM framework is implementation of a care pathway [45;79]. An integrated care pathway that bridges primary care and hospitals, and allows multidisciplinary teams to interact with active patients and communities, facilitated by ITs, can encounter defragmented implementation of the CCM and has an enormous potential for optimising patient care and outcomes like hospital admissions and quality of life $[45 ; 79 ; 94]$. This hypothesis is supported by the fact that the CCM framework and the care pathway tool include comparable concepts like mutual decision making, coordination and supportive environment and resources [45;88;90].

However, as addressed earlier, because of defragmented and diverse CCM implementation strategies and the use of diverse outcome measures, one does not know the active essential components and best practices necessary to build these integrated chronic care pathways [8;9;45]. For this reason, we think that research on the implementation and effectiveness of integrated chronic care pathways should be included on the agenda of next 
challenges in care pathways. Furthermore, when developing this care pathway, the CCM components should be integrated.

\section{Overall conclusions}

Care for patients hospitalised with COPD exacerbations is suboptimal according to widely acknowledged international guidelines, and outcomes are poor and vary greatly among organisations. Care pathways are a possible strategy to optimize care processes and outcomes, though until now the effectiveness of COPD care pathways remained unclear.

An eight-step method was designed to develop the clinical content of an evidence-based COPD care pathway. By applying this eight-step method, a valid and feasible set of 38 key interventions and 39 quality indicators was developed.

An international cluster randomized trial was launched in four countries (Belgium, Ireland, Italy and Portugal), with the aim to evaluate the impact of a care pathway for inhospital management of COPD exacerbation. The care pathway included three active components: feedback on actual performance, integration of the set of 38 evidence based key interventions, and training on care pathway implementation. Evaluation of care pathway effectiveness was based on the set of 39 indicators. Preliminary results of the Belgian CRCT strongly suggest that implementation of this care pathway improved the care process, as an increase in performance levels of 10 to $50 \%$ was found. Moreover, the care pathway has potential for improving clinical outcomes. However, because of limited statistical power, strong conclusions on effectiveness can be drawn only when results of the total sample of the four involved countries become available in 2013-2014.

Despite the improved performance levels demonstrated to date, a considerable number of process indicators remained suboptimal performed. Continuous quality improvement will be needed to further optimise the care process for in-hospital management of COPD exacerbation, and to enhance sustainability of the improved results. 


\section{References}

1 Celli BR, Macnee W. Standards for the diagnosis and treatment of patients with COPD: a summary of the ATS/ERS position paper. Eur Respir J 2004;23:932-946.

2 Global Initiative for Chronic Obstructive Lung Disease (GOLD). Global strategy for the diagnosis, management, and prevention of chronic obstructive pulmonary disease, updated 2010. [http://www.goldcopd.org/guidelines-global-strategy-for-diagnosismanagement.html]

3 Kuzma AM, Meli Y, Meldrum C, Jellen P, Butler-Lebair M, Koczen-Doyle D, Rising P, Stavrolakes K, Brogan F. Multidisciplinary care of the patient with chronic obstructive pulmonary disease. Proc Am Thorac Soc 2008;5:567-571.

4 National Institute for Health and Clinical Excellence (NICE):: Chronic obstructive pulmonary disease - Management of chronic obstructive pulmonary disease in adults in primary and secondary care; 2010. [http://guidance.nice.org.uk/CG101]

5 Siafkas N. Management of chronic obstructive pulmonary disease. Sheffield, European Respiratory Society Ltd, 2006.

6 Sermeus W, De Bleser L, Depreitere R, Dewaele K, Vanhaecht K, Vlayen J. An introduction to clinical pathways.; in Devriese S, Lambert M, Eyssen M, Van de Sande S, Poelmans J, Van Brabandt H, Sermeus W, Vlayen J, Ramaekers D, (eds): The use of clinical pathways and guidelines to determine physicians' hospital fees prospectively: easier said than done.T. Brussels, Belgian Healthcare Knowledge Centre (KCE). KCE Reports, Volume 18A, 2005. [http:/www.kenniscentrum.fgov.be/nl/publicaties.html]

7 Vanhaecht K, Bollman M, Bower K, Gallagher C, Gardine A, Guezo J, Jansen U, Massoud R, Moody K, Sermeus W, Van Zelm R, Whittle C, Yazbeck A, Zander K, Panella M. Prevalence and use of clinal pathways in 23 countries - an internation survey by the European Pathway Association (www.E-P-A-.org). Intl J Care Pathw 2006;10:2834.

8 Medical Research Council (2008). Developing and evaluating complex interventions: new guidance, 2008.

[http://www.mrc.ac.uk/Utilities/Documentrecord/index.htm?d=MRC004871]

9 Panella M, Vanhaecht $\mathrm{K}$. Is there still need for confusion about pathways? Intl J Care Pathw 2010;14:1-3.

10 Vanhaecht K, Ovretveit J, Elliott MJ, Sermeus W, Ellershaw J, Panella M. Have we drawn the wrong conclusions about the value of care pathways? Is a Cochrane review appropriate? Eval Health Prof 2012;35:28-42.

11 Vleugels A. Why pathways cannot taken of the shelf. Intl J Care Pathw 2009;14:150154. 
12 Lodewijckx C, Sermeus W, Vanhaecht k, Panella M, Deneckere S, Leigheb F, Decramer M. Inhospital management of COPD exacerbations: a systematic review of the literature with regard to adherence to international guidelines. Journal of Evaluation in Clinical Practice 2009;15:1101-1110.

13 Lodewijckx C, Sermeus W, Panella M, Deneckere S, Leigheb F, Troosters T, Boto P, Mendeze R, Decramer M, Vanhaecht K. Quality indicators for in-hospital management of exacerbation of chronic obstructive pulmonary disease: results of an international Delphi study. J Adv Nurs. 2012 (Epub ahead of print).

14 Decramer M, Bartsch P, Pauwels R, Yernault JC. Management of COPD according to guidelines. A national survey among Belgian physicians. Monaldi Arch Chest Dis 2003;59:62-80.

15 Hosker H, Anstey K, Lowe D, Pearson M, Roberts CM. Variability in the organisation and management of hospital care for COPD exacerbations in the UK. Respir Med 2007;101:754-761.

16 Panella M, Marchisio S, Di SF. Reducing clinical variations with clinical pathways: do pathways work? Int J Qual Health Care 2003;15:509-521.

17 Vanhaecht K, Sermeus W, Peers J, Deneckere S, Lodewijckx C, Leigheb F, Panella M. The European Quality of Care Pathways (EQCP) Study: history, project managment and approach. Intl J Care Pathw 2010;14:52-56.

18 Vanhaecht K, Sermeus W, Peers J, Lodewijckx C, Deneckere S, Leigheb F, Decramer M, Panella M. The impact of care pathways for exacerbation of Chronic Obstructive Pulmonary Disease: rationale and design of a cluster randomized controlled trial. Trials 2010;11:111.

19 Deneckere S, Euwema M, Lodewijckx C, Panella M, Sermeus W, Vanhaecht K. The European quality of care pathways (EQCP) study on the impact of care pathways on interprofessional teamwork in an acute hospital setting: study protocol: for a cluster randomised controlled trial and evaluation of implementation processes. Implement Sci 2012;7:47.

20 Cunningham S, Logan C, Lockerbie L, Dunn MJ, McMurray A, Prescott RJ. Effect of an integrated care pathway on acute asthma/wheeze in children attending hospital: cluster randomized trial. J Pediatr 2008;152:315-320.

21 De Luca A, Toni D, Lauria L, Sacchetti ML, Giorgi RP, Ferri M, Puca E, Prencipe M, Guasticchi G. An emergency clinical pathway for stroke patients--results of a cluster randomised trial (isrctn41456865). BMC Health Serv Res 2009;9:14.

22 Kinsman LD, Rotter T, Willis J, Snow PC, Buykx P, Humphreys JS. Do clinical pathways enhance access to evidence-based acute myocardial infarction treatment in rural emergency departments? Aust J Rural Health 2012;20:59-66. 
23 Panella M, Marchisio S, Barbieri A, Di SF. A cluster randomized trial to assess the impact of clinical pathways for patients with stroke: rationale and design of the Clinical Pathways for Effective and Appropriate Care Study [NCT00673491]. BMC Health Serv Res 2008;8:223.

24 Panella M, Marchisio S, Demarchi ML, Manzoli L, Di SF. Reduced in-hospital mortality for heart failure with clinical pathways: the results of a cluster randomised controlled trial. Qual Saf Health Care 2009;18:369-373.

25 Institute of Medicine. Improving the $21^{\text {st }}$ Century helath are system. In: Crossing the quality chiasm: A new health system for the $21^{\text {st }}$ Century. Washington, DC, National Academy Press, 2001, pp 39-60.

26 Coulter A, Ellins J. Patient focused interventnions: a review of the evidence. Picker institute Europe, 2006.; 2012.

27 Mosen DM, Schmittdiel J, Hibbard J, Sobel D, Remmers C, Bellows J. Is patient activation associated with outcomes of care for adults with chronic conditions? J Ambul Care Manage 2007;30:21-29.

28 World Health Organization. Modern health care delivery systems, care coordination and the role of hospitals; 2012. [http://www.euro.who.int/en/what-we-do/health-topics/Healthsystems/public-health-services/publications2/2012/modern-health-care-deliverysystems,-care-coordination-and-the-role-of-hospitals]

29 Jaques $\mathrm{H}$. Putting patients at the heart of quality. BMJ 2012;344:e3164.

30 Haughney J, Partridge MR, Vogelmeier C, Larsson T, Kessler R, Stahl E, Brice R, Lofdahl CG. Exacerbations of COPD: quantifying the patient's perspective using discrete choice modelling. Eur Respir J 2005;26:623-629.

31 Kessler R, Stahl E, Vogelmeier C, Haughney J, Trudeau E, Lofdahl CG, Partridge MR. Patient understanding, detection, and experience of COPD exacerbations: an observational, interview-based study. Chest 2006;130:133-142.

32 Ojoo JC, Moon T, McGlone S, Martin K, Gardiner ED, Greenstone MA, Morice AH. Patients' and carers' preferences in two models of care for acute exacerbations of COPD: results of a randomised controlled trial. Thorax 2002;57:167-169.

33 Elsherif M, Noble H. Management of COPD using the Roper-Logan-Tierney framework. Br J Nurs 2011;20:29-33.

34 Ingadottir TS, Jonsdottir H. Partnership-based nursing practice for people with chronic obstructive pulmonary disease and their families: influences on health-related quality of life and hospital admissions. J Clin Nurs 2010;19:2795-2805.

35 Coulter A. Assembling the evidence: patient-focused outcomes research. Health Libr Rev 1994;11:263-268. 
36 Chewning B, Bylund CL, Shah B, Arora NK, Gueguen JA, Makoul G. Patient preferences for shared decisions: a systematic review. Patient Educ Couns 2012;86:9-18.

37 Flynn KE, Smith MA, Vanness D. A typology of preferences for participation in healthcare decision making. Soc Sci Med 2006;63:1158-1169.

38 Ware JE, Jr., Davies-Avery A, Stewart AL. The measurement and meaning of patient satisfaction. Health Med Care Serv Rev 1978;1:1, 3-1,15.

39 Mountford J, Shojania KG. Refocusing quality measurement to best support quality improvement: local ownership of quality measurement by clinicians. BMJ Qual Saf 2012;21:519-523.

40 Rutten-Van Mölken, Lee TA. Economic Modeling in Chronic obstructive Pulmonary Disease. Proc AM Thorac Soc 2006;3:630-634

41 Doran G. There's a S.M.A.R.T. way to write management's goals and objectives. Management Review 1981;70: 35-36.

42 Lodewijckx C, Sermeus W, Vanhaecht k, Panella M, Deneckere S, Leigheb F, Decramer M. Impact of care pathways for in-hospital management of COPD exacerbations: a systematic review. Int J Nurs Stud 2011;48:1445-1456.

43 Federaal Kenniscentrum voor de gezondheidszorg (KCE): Clinical quality indicators; 2012. [https://kce.fgov.be/sites/default/files/page_documents/d20061027343.pdf]

44 Van Gerven E, Vanhaecht K, Deneckere S, Vleugels A, Sermeus W. Management challenges in care pathways: conclusions of a qualitative study within 57 health-care organization. Intl J Care Pathw 2010;142-149.

45 Vanhaecht K, De Witte K, Sermeus W. The Care Process Organisation Triangle: A framework to better understand how clinical pathways work. Intl J Care Pathw 2007;11:1-8

46 Donabedian A. Evaluating the quality of medical care. Milbank Mem Fund $Q$ 1966;44:Suppl-206.

47 Pawson R, Tilly N.: Realistic evaluation. London, SAGE Publications, 1997.

48 Heskett J, Sasser J, Earl W, Schlesinger L. The Service-Profit Chain: How Leading Companies Link Profit and Growth to Loyalty, Satisfaction, and Value. New York, The Free Press, 1997.

49 Teboul J. Service is Front Stage: Positioning Services for Value Advantage. $1^{\text {st }}$ edn. New York, INSEAD Business Press, Palgrave MacMillan, 2006.

50 Batalden PB, Davidoff F. What is "quality improvement" and how can it transform healthcare? Qual Saf Health Care 2007;16:2-3.

51 Mitchell PH, Ferketich S, Jennings BM. Quality health outcomes model. American Academy of Nursing Expert Panel on Quality Health Care. Image J Nurs Sch 1998;30:43-46. 
52 May C, Finch T, Mair F, Ballini L, Dowrick C, Eccles M, Gask L, MacFarlane A, Murray E, Rapley T, Rogers A, Treweek S, Wallace P, Anderson G, Burns J, Heaven B. Understanding the implementation of complex interventions in health care: the normalization process model. BMC Health Serv Res 2007;7:148.

53 Deming W. Out of the Crisis; Cambridge, Massachusetts Institute of Techonolgy, Center for Advanced Engineering Study, 1993.

54 Berwick DM. The science of improvement. JAMA 2008;299:1182-1184.

55 Salas E, King HB, Rosen MA. Improving teamwork and safety: Toward a practical systems approach, a commentary on Deneckere et al. Soc Sci Med 2012.

56 Wiltsey SS, Kimberly J, Cook N, Calloway A, Castro F, Charns M. The sustainability of new programs and innovations: a review of the empirical literature and recommendations for future research. Implement Sci 2012;7:17.

57 Van Herck P, Vanhaecht k, Sermeus W. Effects of Clinical Pathways: do they work? Journal of Integrated Care Pathways Intl J Care Pathw 2004;8:95-105.

58 Rotter T, Kinsman L, James E, Machotta A, Gothe H, Willis J, Snow P, Kugler J. Clinical pathways: effects on professional practice, patient outcomes, length of stay and hospital costs. Cochrane Database Syst Rev 2010;3:CD006632.

59 Leigheb F, Vanhaecht K, Sermeus W, Lodewijckx C, Deneckere S, Boonen S, Boto PA, Mendes RV, Panella M. The Effect of Care Pathways for Hip Fractures: A Systematic Review. Calcif Tissue Int 2012.

60 Kwan J. Care pathways for acute stroke care and stroke rehabilitation: from theory to evidence. J Clin Neurosci 2007;14:189-200.

61 Barbieri A, Vanhaecht K, Van HP, Sermeus W, Faggiano F, Marchisio S, Panella M. Effects of clinical pathways in the joint replacement: a meta-analysis. BMC Med $2009 ; 7: 32$

62 Savitz LA, Kaluzny AD, Kelly DL. A life cycle model of continuous clinical process innovation. J Healthc Manag 2000;45:307-315.

63 Vanhaecht K, De Witte K, Panella M, Sermeus W. Do pathways lead to better organised care processes? Journal of Evaluation in Clinical Practice 2009;15:782-788.

64 Goldmann D. Five puzzle pieces, ten cautionary notes. Intl J Care Pathw 2010;14:33-35.

65 Shortell SM, Bennett CL, Byck GR. Assessing the impact of continuous quality improvement on clinical practice: what it will take to accelerate progress. Milbank $Q$ 1998;76:593-624, 510.

66 O'Neill SM, Hempel S, Lim YW, Danz MS, Foy R, Suttorp MJ, Shekelle PG, Rubenstein LV. Identifying continuous quality improvement publications: what makes an improvement intervention 'CQI'? BMJ Qual Saf 2011;20:1011-1019. 
67 James BC, Savitz LA. How Intermountain trimmed health care costs through robust quality improvement efforts. Health Aff (Millwood) 2011;30:1185-1191.

68 Westbrook JI, Braithwaite J, Gibson K, Paoloni R, Callen J, Georgiou A, Creswick N, Robertson L. Use of information and communication technologies to support effective work practice innovation in the health sector: a multi-site study. BMC Health Serv Res 2009;9:201.

69 Buljac-Samardzic M, Dekker-van Doorn CM, van Wijngaarden JD, van Wijk KP. Interventions to improve team effectiveness: a systematic review. Health Policy 2010;94:183-195.

70 Deneckere S, Euwema M, Van HP, Lodewijckx C, Panella M, Sermeus W, Vanhaecht K. Care pathways lead to better teamwork: Results of a systematic review. Soc Sci Med 2012;75:264-268.

71 Xyrichis A, Ream E. Teamwork: a concept analysis. J Adv Nurs 2008;61:232-241.

72 Benn J, Burnett S, Parand A, Pinto A, Vincent C. Factors predicting change in hospital safety climate and capability in a multi-site patient safety collaborative: a longitudinal survey study. BMJ Qual Saf 2012.

73 Griffiths P, Renz A, Hughes J, Rafferty AM. Impact of organisation and management factors on infection control in hospitals: a scoping review. J Hosp Infect 2009;73:1-14.

74 Hamilton S, McLaren S, Mulhall A. Assessing organisational readiness for change: use of diagnostic analysis prior to the implementation of a multidisciplinary assessment for acute stroke care. Implement Sci 2007;2:21.

75 Institute of Medicine. Building organisatons supports for change. In: Crossing the quality chiasm: A new health system for the $21^{\text {st }}$ Century. Washington, DC, National Academy Press, 2001, pp 111-144.

76 Institute of Medicine. Preparing the workforce. In: Crossing the quality chiasm: A new health system for the 21st Century. Washington, DC, National Academy Press, 2001, pp 207-223.

77 Lin F, Chaboyer W, Wallis M. A literature review of organisational, individual and teamwork factors contributing to the ICU discharge process. Aust Crit Care 2009;22:2943.

78 Lodewijckx C, Vanhaecht K, Panella M. A new model of care pathways for reorganization of chronic care. Intl J Care Pathw 2012;16:1-2.

79 European Respiratory Society. European Respiratory Roadmap: Recommendations for the future respiratory medicine; 2011. [http://www.ersroadmap.org/]

80 Institute of Medicine. A new health system for the 21th century. In Institute of Medicine, (ed): Crossing the quality Chiasm: A A new health system for the 21th century. Washington, DC 20418, National Academy Press, 2001, pp 23-38. 
81 Smith MT, Francis MD, Corrigan JM. Health care quality in the 21st century. Clin Exp Rheumatol 2007;25:3-5.

82 Christensen K, Doblhammer G, Rau R, Vaupel JW. Ageing populations: the challenges ahead. Lancet 2009;374:1196-1208.

83 Wagner EH, Austin BT, Davis C, Hindmarsh M, Schaefer J, Bonomi A. Improving chronic illness care: translating evidence into action. Health Aff (Millwood) 2001;20:6478.

84 Bodenheimer T, Wagner EH, Grumbach K. Improving primary care for patients with chronic illness. JAMA 2002;288:1775-1779.

85 Strandberg-Larsen M. Measuring integrated care. Dan Med Bull 2011;58:B4245.

86 Neubauer K, Kidd E. Investing in Europe's Health Workforce of Tomorrow: Scope for Innovation and Collaboration. Summary Report of the Three Policy Dialogues. Leuven, European Observatory on Health Systems and Policies, 2010.; 2011.

87 Sonetti DA, Hospenthal AC, Adams SG. Integrated management strategies for chronic obstructive pulmonary disease. J Multidiscip Healthc 2010;3:181-188.

88 Wagner EH, Austin BT, Von KM. Organizing care for patients with chronic illness. Milbank Q 1996;74:511-544.

89 Berwick DM. Disseminating innovations in health care. JAMA 2003;289:1969-1975.

90 Barr VJ, Robinson S, Marin-Link B, Underhill L, Dotts A, Ravensdale D, Salivaras S. The expanded Chronic Care Model: an integration of concepts and strategies from population health promotion and the Chronic Care Model. Hosp Q 2003;7:73-82.

91 Coleman K, Austin BT, Brach C, Wagner EH. Evidence on the Chronic Care Model in the new millennium. Health Aff (Millwood) 2009;28:75-85.

92 Weingarten SR, Henning JM, Badamgarav E, Knight K, Hasselblad V, Gano A, Jr., Ofman JJ. Interventions used in disease management programmes for patients with chronic illness-which ones work? Meta-analysis of published reports. BMJ 2002;325:925.

93 Pearson ML, Wu S, Schaefer J, Bonomi AE, Shortell SM, Mendel PJ, Marsteller JA, Louis TA, Rosen M, Keeler EB. Assessing the implementation of the chronic care model in quality improvement collaboratives. Health Serv Res 2005;40:978-996.

94 Seemungal TA, Hurst JR, Wedzicha JA. Exacerbation rate, health status and mortality in COPD--a review of potential interventions. Int J Chron Obstruct Pulmon Dis 2009;4:203223. 


\section{Summary}

Management of patients hospitalised with COPD exacerbations involves a wide range of diagnostic, pharmacological, and non-pharmacological processes. In addition, coordination of the multidisciplinary care process is complex. Implementation of care pathways has become very popular for improving care processes and optimising outcomes. However, until now it remains unclear whether care pathways actually work and which active components are responsible for their effect.

In this PhD research, we examined the impact of a care pathway for COPD exacerbation on care processes and clinical outcomes, by developing new methodology and analysing interim data of an international cluster Randomized Controlled Trial (CRCT).

Firstly, a systematic review was conducted to explore the level of adherence of actual care to internationally acknowledged COPD guidelines. The findings showed that quality of care for these patients was very suboptimal, especially for non-pharmacological management. However, measured indicators were very discordant among previously published studies, and compliance to non-pharmacological processes was scarcely assessed, implying that further research on process adherence is needed.

Secondly, a systematic literature review sought to identify all studies that had examined the development, implementation, and characteristics of existing COPD care pathways, and that had evaluated their impact on care processes, clinical outcomes, and team functioning. Only four studies with a quasi-experimental design were found. The studies described positive effects on diagnostic and non-pharmacological processes; though because of limited reporting of statistics, divergent measurements, and evaluation of a care pathway by means of a historical control group, the internal validity of the results was questionable. Therefore, confident conclusions on the impact of COPD care pathways based on these studies could not be drawn.

Thirdly, in order to rate content validity of process and outcome indicators, an international Delphi study was conducted with a Delphi panel composed of 35 panelists from 15 countries. Among the panellists were 19 medical doctors, 8 nurses, and 8 physiotherapists. Consensus by at least $75 \%$ of panelists that an indicator is relevant for follow-up was reached for 26 of 72 evaluated process indicators (36.1\%) and for 10 of 21 outcome indicators $(47.6 \%)$.

Fourthly, an eight-step method was developed for designing the clinical content of an evidence-based care pathway. Applying this method resulted in a set of 38 evidence-based key interventions and a set of 24 process and 15 outcome indicators, which were piloted and approved by nine multidisciplinary teams. These findings indicate that the sets of key interventions and indicators are appropriate for the standardisation and follow-up of in- 
hospital management of COPD exacerbations. Furthermore, the eight-step method can also help teams in shaping the clinical content of their future care pathways for other patient populations.

Fifthly, the European Quality of Care Pathways study was launched in four countries (Belgium, Ireland, Italy, and Portugal). This is a cRCT aiming to study the impact of care pathways for COPD exacerbations on care processes and clinical outcomes. A second aim was to study why and under what circumstances care pathways work, but this research question was not included in this PhD dissertation. In total, 65 hospitals were randomised, with 33 hospitals assigned to the experimental group in which a care pathway is implemented, and 32 hospitals assigned to a control group in which usual care is provided. The experiment is a complex intervention comprising three active components: (i) feedback on actual performance based on a clinical audit before care pathway implementation, (ii) integration of a set of evidence-based key interventions, and (iii) training on care pathway development and implementation based on the PDSA cycle. The measurements, including follow-up of 24 process and 15 outcome indicators, were conducted in both groups and results were compared to see if care pathway implementation leads to better results.

The EQCP study in Belgium is one year ahead of the other countries (Ireland, Italy, and Portugal), and was conducted between July 2009 and November 2011. Because of timing and feasibility of the PhD, only the results of the Belgian EQCP study are included in the results section of this dissertation. Final results based on the data of all four countries are expected to be analysed in autumn 2013, and will be disseminated by the EQCP study group via publications and conference proceedings in 2013 and 2014. The preliminary results of the Belgian EQCP study strongly suggest that care pathways lead to improved care processes, as an increase in performance levels of 10 to $50 \%$ were found. These results also show that care pathways have the potential to improve clinical outcomes. However, the Belgian sample size is small, and consequently statistical power is limited. Not surprisingly, then, only scarce significant results were found, leading to provisional conclusions at this time. Significant conclusions on the effectiveness of care pathways can only be drawn based on the results of the total sample of the four involved countries. However, according to clinical practice guidelines, the criterion is that all process indicators must meet $100 \%$ performance, regardless of patient characteristics. Consequently, the results on the process indicators, in this case better performance levels of up to $50 \%$ in the care pathway group, may not be considered to be coincidental results arising from chance variation in small samples.

Finally, a process evaluation on the implementation level of the set of evidence-based key interventions was conducted in the seven experimental hospitals in the Belgium EQCP study. Although study coordinators and team members reported that the care activities were highly implemented, these implementation levels did not correspond with the results on 
process indicators after implementation, as a considerable number of indicators were still suboptimally performed. These findings suggest that the teams may have overestimated their own implementation level, and consequently additional measures like interviews and direct observation may be needed to provide more objective information on the implementation process. However, this implementation analysis give teams insight into discrepancies between highly reported implementation levels and subtoptimal performance of the implemented processes. Consequently, this analysis may sensitise the teams that further improvement of the care process is necessary. Secondly, this analysis will provide important insights for other teams planning to implement the care pathway intervention, especially with regard to possible improvement actions and potential barriers for implementation.

The EQCP study will be continued in Ireland, Italy, and Portugal, and the same protocol will be used, including the same intervention and the same measurements. Preliminary results from these countries show that adherence to guidelines is comparable with the Belgian data, implying that considerable room for improvement exists also in these countries.

Although performance levels improved in the care pathway group, half of the indicators remained suboptimally performed, indicating that the complex intervention was adopted but not integrated into daily practice. As a consequence, a Belgian clinical working group on inhospital management of COPD exacerbations will be initiated. The aims of this group will be (i) to further improve in-hospital care for COPD patients experiencing exacerbations, and (ii) to assess and enhance sustainability of results. Therefore, a continous quality improvement (CQI) approach will be used. Important additional focus will be put on team training, patient involvement, and organisational context.

Future research on care pathways should focus on reorganisation of chronic care in order to deal with the current challenges of rising chronic disease, ageing population, and the inevitable shift from hospital-centred medicine to home care and self-management. An integrated care pathway that bridges primary care and hospitals, and allows multidisciplinary teams to interact with active patients and communities, facilitated by information technology (IT), can encounter the current defragmented implementation of the Chronic Care Model (CCM) and has enormous potential for optimising chronic patient care.

In conclusion, the results of this $\mathrm{PhD}$ dissertation strongly suggest that care pathways lead to improved care processes and have potential to optimise clinical outcomes. Nevertheless, to further improve the care process and to enhance sustainability, continuous quality improvement will be needed. 



\section{Samenvatting}

De zorg voor patiënten gehospitaliseerd met een opstoot van Chronisch Obstructief Longlijden (COPD) omvat een heel aantal diagnostische, farmacologische en nonfarmacologische processen, en coördinatie van het multidisciplinaire zorgproces is complex. Een courant gebruikte strategie voor reorganisatie van zorgprocessen en optimalisatie van outcomes is de ontwikkeling en implementatie van een klinisch zorgpad. Echter, omwille van talrijke methodologische redenen blijft het tot vandaag onduidelijk of zorgpaden effectief werken, en welke actieve componenten in zorgpaden juist verantwoordelijk zijn voor een bepaald effect.

In dit proefschrift werd de impact van een zorgpad voor COPD exacerbatie met betrekking tot performantie van zorgprocessen en klinische outcomes bestudeerd. Hiertoe werd een methodologie voor adequaat zorgpadonderzoek ontwikkeld, en vervolgens werd een interim analyse uitgevoerd op de data van een internationale cluster randomized controlled trial (cRCT).

Ten eerste werd een systematisch literatuuronderzoek uitgevoerd om na te gaan in welke mate huidige zorg voor patiënten gehospitaliseerd met COPD exacerbatie voldoet aan internationaal erkende evidence-based standaarden. De bevindingen toonden aan dat zorg voor deze patiënten erg suboptimaal is, zeker met betrekking tot non-farmacologisch management.

Ten tweede werd een literatuuronderzoek uitgevoerd naar studies betreffende ontwikkeling, implementatie, en karakteristieken van COPD zorgpaden, en vervolgens werd hun impact op zorgprocessen, klinische outcomes en teamwerking nagegaan. Slechts vier studies werden gevonden, allen gebruik makend van een quasi-experimenteel design. De studies beschreven positieve effecten met betrekking tot diagnostische en nonfarmacologische processen. Echter de interne validiteit van de studies is beperkt omwille van methodologische tekortkomingen. Bijgevolg was accurate besluitvorming omtrent impact van zorgpaden niet mogelijk op basis van de huidig beschikbare evidentie.

Ten derde werd een internationale Delphi survey uitgevoerd om de inhoudsvaliditeit van een set van proces- en outcome-indicatoren te beoordelen. Het Delphi panel bestond uit 35 panelleden uit 15 verschillende landen, waaronder 19 medische dokters, 8 verpleegkundigen en 8 fysiotherapeuten. Consensus tussen tenminste $75 \%$ van de panelleden dat een indicator relevant is voor follow-up werd bekomen voor 26 van de 72 geëvalueerde procesindicatoren (36.1\%) en voor 10 van de 21 geëvalueerde outcome-indicatoren (47.6\%).

Ten vierde werd een acht-stappenplan opgezet om de inhoud van een evidence-based zorgpad voor COPD-exacerbatie te ontwikkelen. Toepassing van deze methode resulteerde in een set van 38 sleutelinterventies en een set van 24 proces- en 15 outcome-indicatoren, 
welke werden uitgetest en goedgekeurd door negen Belgische multidisciplinaire teams. Dit geeft aan dat de sets van sleutelinterventies en indicatoren geschikt zijn voor standaardisatie en follow-up van zorg voor patiënten gehospitaliseerd met COPD-exacerbatie. Daarnaast heeft het acht-stappenplan ook potentieel om teams te faciliteren in ontwikkeling en standaardisatie van de klinische inhoud van toekomstige klinisch zorgpaden voor andere patiëntengroepen.

Ten vijfde werd de European Quality of Care Pathways (EQCP) Study gelanceerd in vier landen (België, lerland, Italië, en Portugal). Dit is een CRCT, uitgevoerd met als doel de impact van zorgpaden voor COPD exacerbatie met betrekking tot performantie van zorgprocessen en klinische outcomes na te gaan. Een tweede doel is na te gaan hoe en onder welke omstandigheden zorgpaden werken, maar deze onderzoeksvraag was niet inbegrepen in dit proefschrift. In totaal werden 65 ziekenhuizen gerandomiseerd, waarvan 33 ziekenhuizen werden toegewezen aan de experimentele groep waar een klinisch zorgpad wordt geïmplementeerd, en 32 ziekenhuizen werden gerandomiseerd naar de controlegroep waar zorg wordt verleend zoals vóór aanvang van de studie. Het experiment is een complexe interventie, bestaande uit drie actieve componenten: (i) feedback betreffende de kwaliteit van het huidige zorgproces gebaseerd op een klinische audit vooraleer zorgpadimplementatie, (ii) Integratie van een set van evidence based sleutelinterventies, en (iii) training en begeleiding in ontwikkeling en implementatie van een klinisch zorgpad op basis van de Plan Do Act Study cirkel. De metingen, bestaande uit follow-up van 24 proces en 15 outcomen indicatoren, werden uitgevoerd in beide groepen en dan vergeleken om te kijken of zorgpadimplementatie leidt tot betere resultaten.

De Belgische studie is een jaar vooruit op de andere landen en werd uitgevoerd tussen april 2009 en november 2011. Vanwege timing en haalbaarheid werden enkel de resultaten van de Belgische EQCP studie geïncludeerd in deze thesis. Finale resultaten gebaseerd op data van de vier landen worden verwacht in het voorjaar van 2013 , en de resultaten zullen bekendgemaakt worden via publicaties en conferenties. De voorlopige resultaten suggereren dat de implementatie van een klinisch zorgpad leidt tot verbeterde uitvoering van zorgprocessen, aangezien een verbetering van 10 tot $15 \%$ werd gevonden. De resultaten geven ook aan dat zorgpaden potentieel hebben om klinische outcomes te verbeteren. Echter de Belgische steekproefgrootte is klein, en bijgevolg is de statistische power laag. Zoals verwacht werden dan ook slechts enkele significante resultaten gevonden. Significante conclusies omtrent zorgpadeffectiviteit zijn pas mogelijk op basis van alle data uit de vier landen. Echter, in overeenstemming met de klinische praktijkrichtlijnen dient elke procesindicator uitgevoerd te worden voor elke patiënt (performantieniveau van 100\%), ongeacht patiëntenkarakteristieken. Bijgevolg mogen de resultaten van $50 \%$ verbeterde 
performantie in de zorgpadgroep niet bestempeld worden als toevallige resultaten die voortvloeien uit de toevallige variatie in kleine steekproeven.

Tot slot werd een procesevaluatie met betrekking tot implementatie van de set van 38 sleutelinterventies uitgevoerd in de zeven experimentele ziekenhuizen uit de Belgische EQCP study. Hoewel de studiecoördinators en teamleden rapporteerden dat de sleutelinterventies in sterke mate geïmplementeerd werden, komen deze resultaten niet overeen met de performantieresultaten na implementatie, aangezien een belangrijk aantal indicatoren suboptimaal werd uitgevoerd. Deze bevindingen geven aan dat de teams hun implementatieproces mogelijk overgeschat hebben. Bijkomende interviews en directe observatietechnieken zijn dan ook aangewezen om meer objectieve informatie omtrent het implementatieproces te verzamelen. Echter, deze implementatie-analyse kantegenstrijdigheden tussen de hoog gerapporteerd implementatieniveaus en subtoptimale uitvoering van de geïmplementeerde processen belichten, en bijgevolg teams sensibiliseren met betrekking tot nood aan verdere optimalisatie van het zorgproces. Ten tweede kan deze procesanalyse ook belangrijke inzichten leveren omtrent verdere verbeteracties en implementatiebarrières voor andere COPD teams die de zorgpadinterventie willen implementeren.

De EQCP studie zal verder gevoerd worden in de andere drie landen: lerland, Italië en Portugal, en hierbij zal gebruik gemaakt worden van hetzelfde protocol, inclusief dezelfde interventie en dezelfde metingen. De eerste resultaten geven aan dat ook in deze landen compliance met betrekking tot internationale standaarden laag is, en dat ook hier belangrijke ruimte voor verbetering aanwezig is.

Ondanks een verbetering van de performantie in de zorgpadgroep, werd de helft van de indicatoren nog steeds suboptimaal uitgevoerd. Dit wijst er op dat de interventie nog niet volledig is ingebed in de dagelijkse klinische praktijk. Daarom zal in België een klinische werkgroep betreffende zorg voor patiënten gehospitaliseerd met COPD exacerbatie opgestart worden. Het doel is tweeledig: (i) zorg voor patiënten gehospitaliseerd met COPD verder optimaliseren, en (ii) duurzaamheid van de verbeterde resultaten nagaan en bewerkstelligen. Hiertoe zal gebruikt gemaakt worden van een Continous Quality Improvement (CQI)-benadering. Bijzondere focus zal liggen op teamtraining, patiëntgerichtheid, en de organisationele context.

Tenslotte, in de context van het stijgend aantal chronisch zieken, de vergrijzing van de bevolking, en de onvermijdbare shift van ziekenhuiszorg naar thuiszorg en zelfzorg, zien wij de nood voor onderzoek naar een nieuw model van zorgpaden, gericht op organisatie van chronische zorg. Geïntegreerde zorgpaden die een brug vormen tussen de eerstelijns gezondheidszorg en ziekenhuizen, en die multidisciplinaire teams toelaten om samen te werken met actieve patiënten en gemeenschappen, gefaciliteerd door informatiesystemen, 
kunnen tegemoetkomen aan de huidige gedefragmenteerd implementatie van het Chronic Care Model en hebben enorm potentieel voor het optimaliseren van de chronische patiëntenzorg.

In conclusie, de resultaten van dit proefschrift suggereren in sterke mate dat implementatie van zorgpaden leidt tot optimalisatie van zorgprocessen, en dat er potentieel is voor een verbetering in klinische outcomes. Echter, continue kwaliteitsverbetering is aangewezen, enerzijds om het zorgproces verder te optimaliseren, en anderzijds om het effect op lange termijn te bewerkstelligen. 


\section{Curriculum Vitae Cathy Lodewijckx}

Cathy Lodewijckx was born on November 17, 1976, in Diest, Belgium. She obtained her bachelor degree in nursing in 1997, and in the same year she started working as a registered nurse in an inpatient respiratory ward at the University Hospitals Leuven. In 1998 she fulfilled a postgraduate course in pulmonary nursing at the University Hospitals Leuven.

In 2001 she started her studies for a Master of Nursing Science degree at KU Leuven, Belgium, while she worked part-time as a bachelor nurse. She obtained her master's degree in nursing science in 2004. In the same year she incorporated a part-time mandate as clinical nurse specialist in COPD, while being employed part-time in the respiratory ward at the University Hospitals Leuven. From 2007 to 2008 she participated in the Clinical Leadership Project at the University Hospitals Leuven. She has been an active member of the Belgian Society for Respiratory Nurses (BVPV) since October 2004. In September 2006 she was elected vice-president of this society, and in 2011 she became president of the BVPV. In addition, she has been a member of the European Respiratory Society (ERS) since 2005. In 2012 she was elected chair of the ERS Group 09.03 Nurses.

In October 2008 she started a research fellowship at the Centre for Health Services and Nursing Research, KU Leuven, while working part-time as a clinical nurse specialist in COPD at the University Hospitals Leuven. At the same time, she started her $\mathrm{PhD}$ study on the impact of care pathways for COPD exacerbation. This study was integrated into the European Quality of Care Pathways (EQCP) study, an international cluster randomised controlled trial on care pathway effectiveness. Subsequently, she became a member of the European Pathway Association (E-P-A), who managed the EQCP study. From 2010 to 2012 she has participated in a 3-year doctoral summer school on Complex Interventions at the European Academy of Nursing Science (EANS). 



\section{List of publications}

Lodewijckx C, Sermeus W, Panella M, Deneckere S, Leigheb F, Troosters T, Boto PAF, Mendez RV, Decramer M, Vanhaecht K. Quality indicators for in-hospital management of exacerbation of chronic obstructive pulmonary disease: results of an international Delphi study. J Adv Nurs. 2012. doi: 10.1111/j.1365-2648.2012.06013.x. [Epub ahead of print]

Vanhaecht K, Deneckere S, Van Gerven E, Lodewijckx C, Janssens I, Van Zelm R, Boto PAF, Panella M, Biringer E, Sermeus W. The 7-phase method to design, implement and evaluate care pathways. Int J Pers Cent Med. 2012. In press.

Vanhaecht K, Sermeus W, Peers J, Lodewijckx C, Deneckere S, Leigheb F, Boonen S, Sermon A, Boto P, Mendes R, Panella M, For The Eqcp Study Group. The impact of care pathways for patients with proximal femur fracture: rationale and design of a clusterrandomized controlled trial. BMC Health Serv Res 2012;12:124.

Deneckere S, Euwema M, Lodewijckx C, Panella M, Sermeus W, Vanhaecht K. The European quality of care pathways (EQCP) study on the impact of care pathways on interprofessional teamwork in an acute hospital setting: study protocol for a cluster randomised controlled trial and evaluation of implementation processes. Implement Sci 2012;7:47.

Leigheb F, Vanhaecht K, Sermeus W, Lodewijckx C, Deneckere S, Boonen S, Boto PAF, Mendez RV, Panella M The Effect of Care Pathways for Hip Fractures. A Systematic Review. Calcif Tissue Int 2012. DOI 10.1007/s00223-012-9589-2.

Lodewijckx C, Vanhaecht K, Panella M. Editorial: A new model of care pathways for reorganization of chronic care. Intl J Care Pathw 2012 16:1 - 2.

Deneckere S, Euwema M, Van Herck P, Lodewijckx C, Panella M, Sermeus W, Vanhaecht K Care Pathways Lead to Better Teamwork: Results of a Systematic Review. Soc Sci Med. 2012. Accepted for publication.

Boonen S, Milisen K, Gielen E, Meeuwissen J, Lodewijckx C, Vanhaecht K. Farmacologische osteoporosebehandeling, valpreventieve maatregelen en geriatrische nazorg in het kader van een zorgpad voor heupfractuurpatiënten. Tijdschr Geneeskd 2011;67 (5); 205-214.

Lodewijckx C, Sermeus W, Vanhaecht K, Panella M, Deneckere S, Leigheb F, Decramer M, for the EQCP study group. Impact of care pathways for in-hospital management of COPD exacerbation: a systematic review. Int J Nurs Stud. 2011;48:1445-56. 
Deneckere S, Robyns N, Vanhaecht K, Euwema M, Panella M, Lodewijckx C, Leigheb F, Sermeus W. Indicators for follow-up of multidisciplinary teamwork in care processes: results of an international expert panel. Eval Health Prof. 2011;34(3):258-77.

Vanhaecht K, Sermeus W, Peers J, Lodewijckx C, Deneckere S, Leigheb F, Decramer M, Panella M, for the EQCP study group. The impact of care pathways for exacerbation of Chronic Obstructive Pulmonary Disease: Rationale and design of a cluster randomized controlled trial (NCT00962468). Trials 2010,11:111 doi:10.1186/1745-6215-11-111.

Vanhaecht K, Sermeus W, Peers J, Deneckere S, Lodewijckx C, Leigheb F, Panella, M. The European Quality of Care Pathway (EQCP) Study: history, project management and approach. IntI J Care Pathw 2010;45:52-56.

Lodewijckx C, Sermeus W, Vanhaecht K, Deneckere S, Leigheb F, Panella M, Decramer M. In-hospital management of COPD exacerbations: a systematic review of the literature with regard to adherence to international guidelines. J Eval Clin Pract 2009;15:1101-10. 


\section{ACTA BIOMEDICA LOVANIENSIA}

532. L. LUYTEN, Neuroimaging and Therapeutic Brain Lesions in an Animal Model for Generalized Anxiety Disorder. 2011

533. D. NAPIERSKA, Physico-Chemical Determinants of the Toxicity of Silica Nanoparticles. 2011

534. L. Bammens, Topological and Functional Analysis of Pen-2, the Fourth Subunit of the y-Secretase Complex. 2011

535. A. AGTEN, Ventilator-Induced Diaphragm Dysfunction: Towards a Better Understanding. 2011

536. C. MEERS, The Use of Extended Criteria Donors for Lung Transplantation. A Clinical and Experimental Study. 2011

537. J. Verguts, Can Prevention of Mesothelial Damage During Endoscopic Surgery Decrease Adhesion Formation and Tumor Implantation? 2011

538. L. Trovò, Plasma Membrane Lipids Homeostasis in Normative Brain Ageing: a Mechanistic Link Between Neuronal Survival and Plasticity. 2011

539. S. De Vleeschauwer, Tackling Major Pitfalls in Lung Transplantation. 2011

540. L. JACOBS, Cardiovascular Health Effects of Particulate Matter Air Pollution in Susceptible Populations. 2011

541. G. Sergeant, Perioperative Cancer Cell Dissemination and Systemic Immunological Changes in Resectable Pancreatic Ductal Adenocarcinoma. 2011

542. N. VAN TILBORGH, Coactivator Interactions at the Transcription Activation Units of the Androgen Receptor. 2011

543. K. NYS, On the Role and Regulation of UVB- and Mild Hypoxia-Induced Signaling Pathways in Epidermal Cells. 2011

544. T. JAWORSKI, Generation and Characterization of Adeno-Associated Viral Model for Protein Tau-Mediated Neurodegeneration and the Role of GSK3 in Alzheimer's Disease. 2011

545. A. LEHOUCK, Vitamin D as Treatment for COPD. 2011

546. R. CoRona, The Role of the Entire Peritoneal Cavity in Post-Operative Adhesion Formation: from the Laboratory to the Operating Theatre. 2011

547. Q. LIU, Assessment of Liver Graft Viability During Hypothermic Machine Perfusion Preservation.2011

548. A. VAN HOECKE, The Zebrafish as a Screening Tool for Disease Modifying Genes in Amyotrophic Lateral Sclerosis. 2011

549. B. DE FOER, The Value of Magnetic Resonance Imaging in the Preoperative Evaluation and the Postoperative Follow-Up of Middle Ear Cholesteatoma. 2011

550. M. GEES, TRP Channel Modulation by Natural Compounds. 2011

551. L. ZHOU, Antibody-Based Inhibition and Functional Studies of BACE1, the $\beta$-Secretase in Alzheimer's Disease. 2011

552. M. RINALDI, A Smoke-Induced Emphysema Mouse Model: Moving Towards a Clinical Model for COPD. 2011

553. N. Chumerin, From Multi-Channel Vision Towards Active Exploration. 2011

554. S. KERKHOFS, Physiological Role of Selective Androgen Response Elements. 2011

555. T. PHILIPS, Non-Neuronal Cells in the Pathogenesis of Amyotrophic Lateral Sclerosis. 2011

556. A. DECRAENE, Importance of the Adaptive Immunity in the Pathophysiology of Cystic Fibrosis Lung Inflammation. 2011 
557. F. KREMER, Ultrasonic Assessment of 2D Cardiovascular Deformation at High Spatial and Temporal Resolution. 2011

558. Y.OzoG, Theoretical and Experimental Evaluation of Implant Materials Used in Pelvic Organ Prolapse Repair. 2011

559. C. VAN HUMBEECK, Parkin Interacts with Ambra1 to Induce Mitophagy. 2012

560. C. VAN OUTRYVE D'YDEWALLE, HDAC6 Inhibition Reverses Axonal Loss in a Mouse Model of Mutant HSPB1-Induced Charcot-Marie-Tooth Disease. 2012

561. A. KREMER, Characterization and Validation of Transgenic Mice as Models for Different Pathological Aspects of Alzheimer's Disease. 2012

562. S. JANSSEN, Bitter and Fatty Acid Sensing Mechanisms of the Ghrelin Cell. 2012

563. B. JACOBS, EGFR Ligand Expression in Colorectal Cancer, Therapeutic and Prognostic Implications. 2012

564. S. HAENEN, Proteomics and Peptidomics in the Search for (Early) Biomarkers of Asthma. 2012

565. M. WYNANTS, Role of Inflammation in Chronic Thromboembolic Pulmonary Hypertension. 2012

566. V. UYTTERHOEVEN, Loss of Skywalker Reveals Synaptic Endosomes as Sorting Stations for Synaptic Vesicle Proteins. 2012

567. T. M. KUONG, The Role of $\mathrm{PI}(4,5) \mathrm{P}_{2}$ and $\mathrm{PI}(3,4,5) \mathrm{P}_{3}$ in Synaptic Function and Development. 2012

568. S. MATTA, LRRK2 Controls an EndoA Phosphorylation Cycle in Synaptic Endocytosis. 2012

569. F. IANNILLI, Role of Telomerase in Neuronal Survival during Aging. 2012

570. M. SugHIS, Health Effects of Environmental and Occupational Exposures in Children of Pakistan. 2012

571. C. BURTIN, Exercise Training in Respiratory Patients: Identifying and Overcoming Barriers. 2012

572. H. GAO, Imaging Left Ventricular Flow Patterns with Ultrasound: 2D Estimation by Combining Speckle Tracking with Navier-Stokes Based Regularization. 2012

573. A. NEYRINCK, Donor Lung Injury: Pathophysiological Evaluation and Cellular Mechanisms. 2012

574. N. VAN DESSEL, A Key Function for the PP1 Interactor NIPP1 in Cancer Cell Proliferation and Gene Expression. 2012

575. A. WIDYASTUTI, The Role of Fibroblast Growth Factors in Bronchial Remodeling and Angiogenesis. 2012

576. I. TAES, Modulators of the Microtubule Network in the Pathogenesis of Amyotrophic Lateral Sclerosis. 2012

577. V. Hox, Effects of Occupational Agents on Upper and Lower Airway Function. 2012

578. S. WAUTERS, Assessment of Donor Lung Injury Following Brain Death. A Clinical and Experimental Study. 2012

579. Y. JIN, Genetic Determinants of Sodium Handling in Relation to Left Ventricular Structure and Function. 2012

580. V. CARLIER, Modulation of T Cell Responses in Specific Immunotherapy with Modified Peptides. 2012

581. D. BoshofF, Endovascular Balloon Dilation and Stent Implantation in Congenital Cardiology: Novel Indications and Evolving Techniques. 2012

582. C. LODEWIJCKX, Impact of a Care Pathway for Exacerbation of Chronic Obstructive Pulmonary Disease (COPD): a Cluster Randomised Controlled Trial. 2012 